University of Louisville

ThinkIR: The University of Louisville's Institutional Repository

Electronic Theses and Dissertations

$12-2012$

\title{
Studies in the image of the Madonna lactans in late medieval and Renaissance Italy.
}

Cecelia M. Dorger

University of Louisville

Follow this and additional works at: https://ir.library.louisville.edu/etd

\section{Recommended Citation}

Dorger, Cecelia M., "Studies in the image of the Madonna lactans in late medieval and Renaissance Italy." (2012). Electronic Theses and Dissertations. Paper 367.

https://doi.org/10.18297/etd/367

This Doctoral Dissertation is brought to you for free and open access by ThinkIR: The University of Louisville's Institutional Repository. It has been accepted for inclusion in Electronic Theses and Dissertations by an authorized administrator of ThinkIR: The University of Louisville's Institutional Repository. This title appears here courtesy of the author, who has retained all other copyrights. For more information, please contact thinkir@louisville.edu. 


\section{STUDIES IN THE IMAGE OF THE MADONNA LACTANS IN LATE MEDIEVAL AND RENAISSANCE ITALY}

By

\section{Cecelia M. Dorger}

B.S. University of Dayton, 1979

M.A. University of Cincinnati, 1982

A Dissertation Submitted to the Faculty of the College of Arts and Sciences, University of Louisville in Partial Fulfillment of the Requirements of the Degree of

Doctor of Philosophy

Department of Art History

University of Louisville

Louisville, Kentucky

December 13, 2012 
Copyright 2012 by Cecelia M. Dorger

All rights reserved 
STUDIES IN THE IMAGE OF THE MADONNA LACTANS IN LATE MEDIEVAL AND RENAISSANCE ITALY

By

Cecelia M. Dorger

B.S., University of Dayton, 1979

M.A., University of Cincinnati, 1982

A Dissertation Approved on

November 20, 2012

By the following Dissertation Committee:

Christopher B. Fulton, Dissertation Director

Delin Lai

William R. Levin

Elaine O. Wise 
For Ken,

Madeline, and Ben 


\section{Acknowledgements}

This dissertation would have been inconceivable without the patient guidance, incisive suggestions, and unwavering support of Christopher Fulton. Without William Levin's insight and extensive acquaintance with this subject, and the many hours he generously gave to the task, this study would not have been possible. I am also grateful for the gift of time and astute suggestions given by my reading committee members Elaine Wise and Delin Lai. I have benefitted from competent assistance patiently given by Kathy Moore and Gail Gilbert at the University of Louisville Art Library and Janice Blair of the Art History Department. I am grateful for the superb library staffs at The Hamilton County Public Library, the University of Dayton Marian Library, and Kunsthistorisches Institut in Florence. I am deeply indebted to Giorgio Marini of the Gabinetto Disegni e Stampe degli Uffizi for his solicitous help. Archivist Luccia Ricciardi was a godsend at the Spedale degli Instituto degli Innocenti.

I am exceedingly appreciative of the grants and scholarships I received from the University of Louisville's Hite Art Institute and Department of Fine Arts. The Frederick and Elizabeth Cressman Scholarship, the Don Payton Graduate Award, the Hite Scholarship, and the Hite School of Fine Arts Travel Award allowed me conduct my research at home and in Italy. I am exceedingly grateful for the help with Latin translations I received from Reverend Thomas Franxman, Peter van Minnen, Andrew Connor, and Michael Klabunde. The support from teachers, friends, and family 
members gave me energy when I needed it. I am deeply grateful for Nettina Eckert, Sylvia Schneider, my wonderful prayer group, Mary Robertson, Joe Marten, Jim Marten, and my role model, Madge Marten.

Without the generous counsel of Bill Cleves on all matters theological, liturgical, etymological, and metaphysical this dissertation would have been impossible. He exhibited reserves of patience and epitomized charitable giving when I asked for help with the translation of fourteenth-century Italian, Latin, and his keen editing eye. He explained the Church's definition of a miracle. His profuse help fits the definition nicely.

Another hundred pages would be necessary to adequately express my thanks to my children and husband. I appreciate Ben's encouraging phone calls from the chair lift, the rock, and the bus stop. Every museum visit and art discussion is folded into this study. My fabulous editor and brilliant daughter, Madeline put up with never-ending conversations about the Virgin Mary and the Milk and Blood. She applied her bright mind to the task and was quick to make me laugh. I shall miss discussing local food movements with her.

I know God loves me when I look at my husband. Surely I do not deserve such a patient, thoughtful, generous, sincere, loving mate. He was always in my corner and listened with his whole heart. He endured separation when I traveled and many dinnerless evenings. He gave me comfort through the rough spots and was quick to celebrate the big and small triumphs. He made the journey a pleasure. He makes life a pleasure.

Finally a debt of gratitude is owed to my late Dad who was influential in cultivating my curiosity about the Virgin Mary. 


\section{ABSTRACT \\ Studies in the Image of the Madonna Lactans in Late Medieval and Renaissance Italy}

\section{Cecelia M. Dorger}

December 13, 2012

This dissertation is an analysis of Italian late medieval and Renaissance peoples’ response to the Madonna lactans image. Although the images that comprise this type are similar in that Mary holds Christ at her breast, they vary widely in iconography and context. We shall use reception and response theory to determine how the image functioned for spectators. Determining how different groups responded to the motif is facilitated by applying an interpretive community model. Hence a group’s interpretive principles connect these communities and inform their reception of the image. We argue that although context and communities are diverse, most people believed the image to be a conduit to the divine.

Our study is divided into four chapters covering a late medieval through Renaissance history of breastfeeding, devotion, the motif as an altarpiece, and reception by Renaissance people. Chapter one gives a historical overview of the advice 
concerning breastfeeding to which medievals were subjected. In light of sacerdotal advice, we argue that the Church used the image to promote maternal feeding. We also consider wet nurses as a community and audience. Chapter two draws on social and historical inquiries to explore public and private devotion. We highlight the Madonna lactans as an intercessor. While chapter one and two provide a historical and social foundation, the next two chapters consider different interpretive communities' experiential viewing. Chapter three argues that the late medieval altarpiece image was more than an aesthetic illusion for churchgoers, finding that the image was believed to have sacramental value. Theories about medieval vision are applied to viewing religious rites with images. Chapter four delves into several communities' interpretive principles. First, in light of its increased naturalism, we argue against a prurient reading of the image by applying scientific studies, an iconographic analysis, and period laws. Second, we find that nuns perceived the image to be a means to intimacy with Christ. One nun's desire for contemplation before the image was so ardent, she drew it for her private edification, at great personal risk. Finally, we argue that when the viewer held the interpretive power, lay people embraced the image’s intercessory message. 


\section{Table of Contents}

PAGE

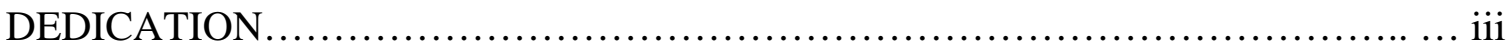

ACKNOWLEGEMENTS ...........................................................

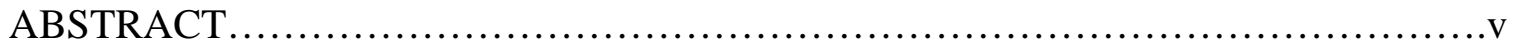

LIST OF ILLUSTRATIONS AND CHARTS......................................viii

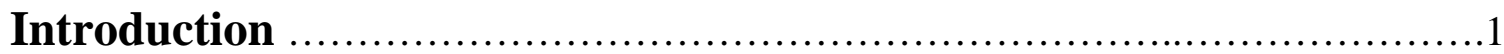

Chapter One: The Virgin and the Wet Nurse ..................................17

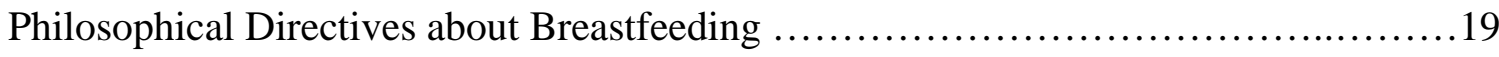

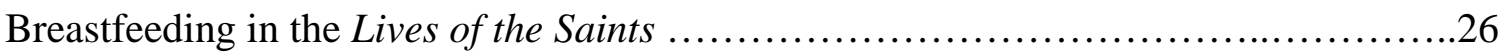

Breastfeeding from the Medical Perspective .......................................31

The Mysterious Properties of Breast Milk.........................................37

The Wet Nurse: Habits and Environment ....................................41

Why Hire a Wet Nurse?..................................................49

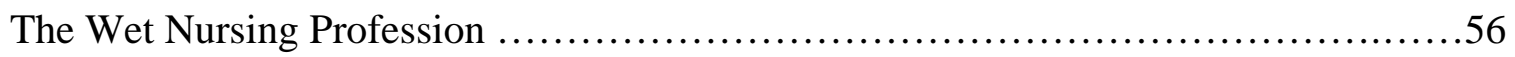

The Institutional Wet Nurse .................................................61

Madonna Lactans Adorning Charitable Institutions.....................................54

Chapter Two: Italian Devotion to the Nursing Madonna..........................72

Origins and Expansion of Medieval and Renaissance Marian Devotion..................74

Public Marian Devotion in Late Medieval Italy ....................................86

Late Medieval Private Devotion.................................................88

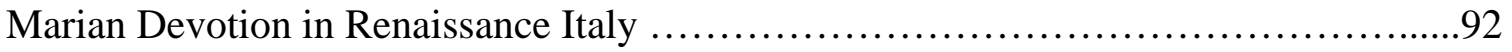

Public Marian Devotional Rituals.............................................92

Intersection Between Public and Private Devotion................................95 
Private Marian Devotion in Renaissance Italy................................... 100

Chapter Three: Sustenance for Life ...................................... 117

Late Medieval Devotion to the Eucharist ......................................121

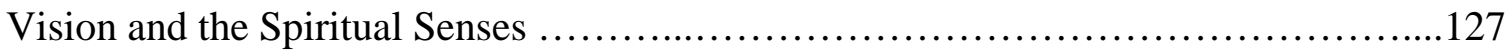

The Madonna Lactans as an Altarpiece Image..................................129

The Blood and the Milk ..................................................142

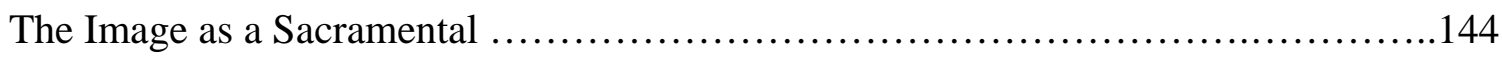

Chapter Four: Viewers, Visionaries \& Voyeurs: Renaissance Reception ..............151

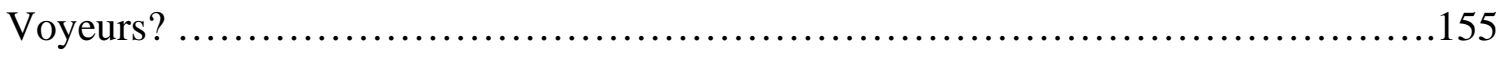

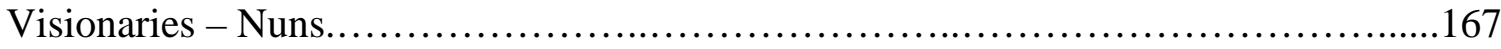

Female Patrons and Artists of the Madonna Lactans ..............................179

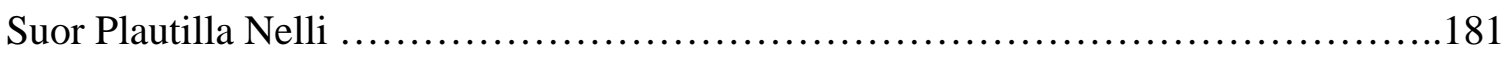

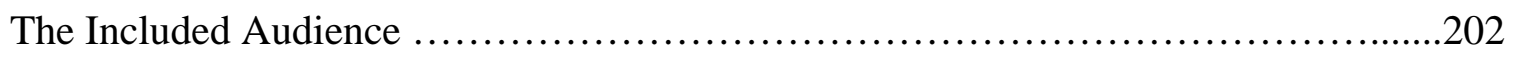

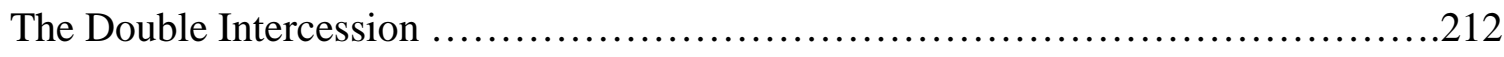

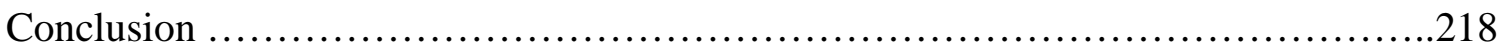

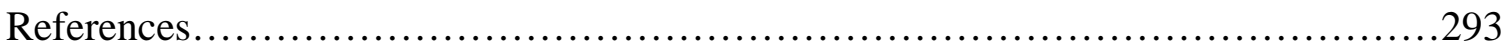




\section{LIST OF ILLUSTRATIONS}

FIGURE

PAGE

1. Virgin Suckling the Christ Child, Catacomb of Priscilla, Rome.

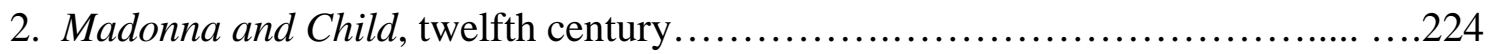

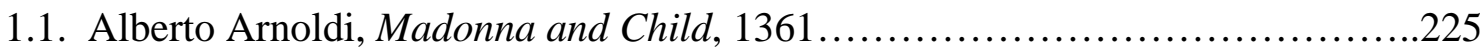

1.2. Cenni di Francesco di Ser Cenni, Madonna with Child, late fourteenth or early

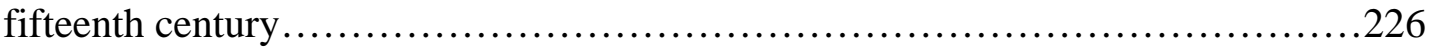

1.3.Domenico Ghirlandaio, Birth of John the Baptist, 1485 - 90....................227

1.4.Tomasso del Mazza, Madonna and Child with Six Saints, ca. 1390....................228

1.5. Pietro da Rimini, Madonna and Child, early fourteenth century................229

1.6. Gregorio di Cecco, Virgin of Humility with Angels and Saints, detail of polyptych

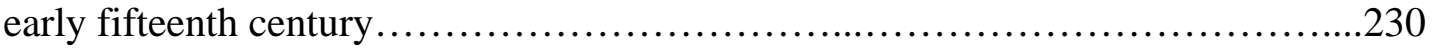

1.7. Jacopo Tintoretto, The Birth of John the Baptist, 1550s......................231

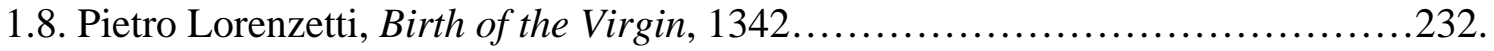

1.9. Domenico Ghirlandaio, Birth of the Virgin, $1485-90 \ldots \ldots \ldots \ldots \ldots \ldots \ldots \ldots \ldots . . . \ldots 233$

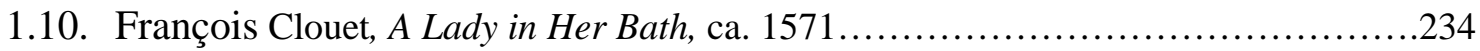

1.11. Florentine Arruccio, fifteenth-century .................................235

1.12. Marco della Robbia called Frate Mattia, The Madonna and Saint Joseph, 1505..... .235

1.13. Ambrogio da Fossano, Madonna del Latte.................................236

2.1. Master of Osma, Lactation of St. Bernard from a Retable of St. Ildefonso, ca. 1460 
2.2. Andera della Robbia, Historical Relief, Collegiata di S. Lorenzo, Montevarchi....238

2.3. The Annunciation, St. Albans Psalter, 1120s...................................238

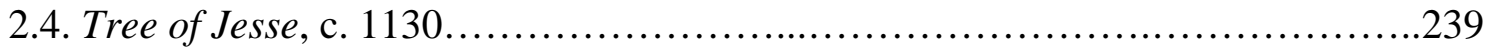

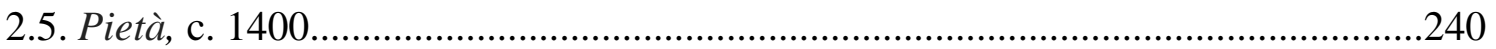

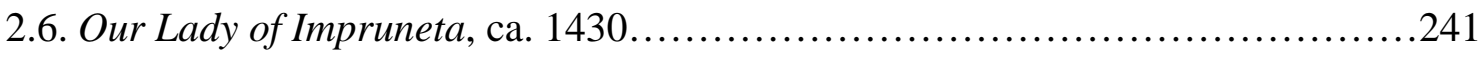

2.7. Filippo Dolciati, The History of Antonio Rinaldeschi, $1502 . . . \ldots \ldots \ldots \ldots \ldots \ldots . . . .242$

2.8. Filippo Dolciati, The History of Antonio Rinaldeschi, detail, $1502 \ldots . . . \ldots \ldots . . . . .243$

2.9. Correggio, Madonna and Child with an Angel. ca.1525.........................244

2.10. Vittorio Carpaccio, Scenes from the Life of St. Ursula: Arrival of the Ambassadors,

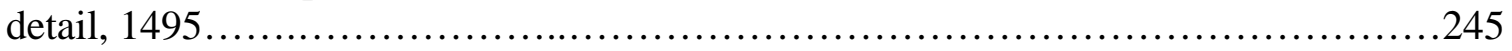

2.11. Vittorio Carpaccio, Scenes from the Life of St. Ursula, detail, 1495................246

2.12. Vittorio Carpaccio, Scenes from the Life of St. Ursula, detail of tabernacle frame.....

2.13. Donatello circle, Madonna and Child before a Niche, 1440s....................247

2.14. Artist unknown, after Andrea Solario’s Madonna with Green Cushion.............248

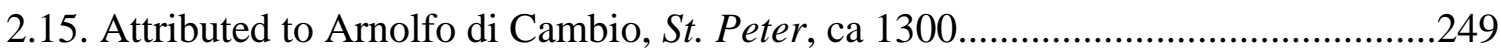

2.16. Attributed to Arnolfo di Cambio, detail of St. Peter's right foot....................250

2.17. Moderno, Virgin and Child with Saint Anthony Abbot and St. Jerome..............251

2.18. Moderno, Madonna and Child with Donor, Tympanum with God and Cherub....252

2.19. Attributed to Donatello, Madonna del Latte......................................................253 
3.1. Artist Unknown, Franciscan Crib with the Madonna del Latte, fourteenth century.... .254

3.2. Artist Unknown, detail of Franciscan Crib with the Madonna del Latte.... .255

3.3. Barnaba da Modena, Virgin with Child, ca. 1370 256

3.4. Barnaba da Modena, detail of Virgin with Child. 257

3.5 Agnolo Gaddi, Madonna and Child, ca. 1390 .258

3.6. Puccio di Simone, Madonna of Humility, mid-fourteenth century. ... .259

3.7. Ambrogio Lorenzetti, Madonna del Latte, ca.1340. .260

4.1. Masolino di Panicale, Madonna and Child, 1436 .261

4.2. Andrea Solario, Madonna with Green Cushion, ca. 1507 .263

4.3. Gian Giacomo di Alladio, called Marcino d’Alba, Madonna del Latte, 1510 .264

4.4. Andrea Solario, Madonna and Child, c. 1500. .265

4.5. Andrea Solario, Cleopatra, early sixteenth century. .266

4.6. Andrea di Bartolo, Madonna of Humility, ca. 1394-1415. .267

4.7. Fra Angelico, Eighteen Dominican Beati, 1425. .268

4.8. Liturgical cradle from the Grand Beguinage in Louvaine, fifteenth century..... .269

4.9. Anonymous, Consecration of Virgins, c. 1500. .270

4.10. Quirizio da Murano, The Savior, 1460-1478. .271 
4.11. Taddeo di Bartolo, Virgin and Child with Saint John the Baptist and Saint Andrew,

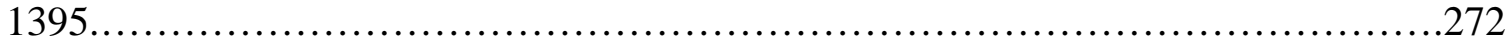

4.12. Plautilla Nelli, Seated Madonna Nursing, sixteenth century.....................273

4.13. Plautilla Nelli, Lamentation, sixteenth century................................................274

4.14. Plautilla Nelli, Lamentation, detail...............................................................275

4.15. Plautilla Nelli, Pentecost, sixteenth century.................................................276

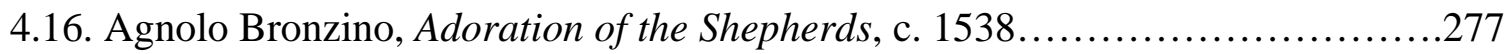

4.17. Plautilla Nelli, Partial Study of Michelangelo’s Risen Christ....................278

4.18. Fra Bartolommeo Study for the Head of the Virgin..............................279

4.19. Plautilla Nelli, Seated Madonna Nursing, detail..............................279

4.20. Bartolommeo Study for a Woman Nursing a Baby.............................280

4.21. Girolamo Savonarola,Compendio di revelatione, 1496......................................281

4.22. Michelangelo, Madonna and Child, ca.1525 - 30............................282

4.23. Ambrogio da Fossano, called Bergognone, Madonna del Latte, (active in Milan

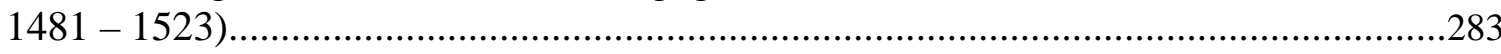

4.24. Ambrogio Bergognone. The Virgin and Child, ca.1488 - 90..................284

4.25. Giovanni di Pietro (called lo Spagna), Madonna del Latte between Saint Mary Magdalene and Saint Anthony of Padua, ca. first quarter of the sixteenth century......285

4.27. Luca Signorelli, Madonna in Glory with Angels............................................286

4.28. Marco d’Oggiono Madonna del Latte, late fifteenth or early sixteenth century....287 
4.29. Bartolomeo Suardi called Bramantino, Virgin and Child, 1485 - 90.

4.30. Attributed to Lorenzo Monaco (Piero di Giovanni), The Intercession of Christ and the Virgin, ca. 1402 ...................................................................................................289

4.31. Double Intercession, Turin-Milan Book of Hours, mid-fifteenth century..........290

4.32. Benozzo Gozzoli, Saint Sebastian, Intercessor, detail, $1464 \ldots \ldots \ldots \ldots \ldots \ldots \ldots \ldots \ldots . . . . .291$

4.33. Benozzo Gozzoli, Saint Sebastian, Intercessor, 1464...........................................292

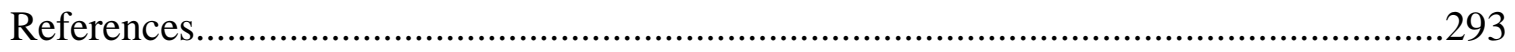

\section{CHARTS}

CHART

PAGE

1. Various ways and percentages breasts were depicted or dealt with in one hundred and fifty-three Italian Renaissance Madonna lactans images from the fifteenth century and the first quarter of the sixteenth certury ..........................................240

2. Totals of the ways non-feeding breasts were dealt with vs. both breasts naturally

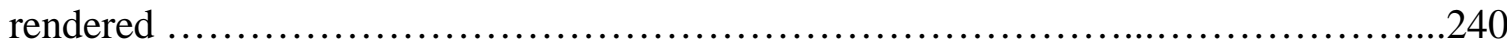




\section{INTRODUCTION}

Events in the Virgin Mary's life were the subject of a great many medieval and Renaissance religious images and furnished people with a reflection of their own experiences or a projection of an ideal. Based on the sheer number of these representations, it can be said that Marian images held the attention of Christian viewers from the medieval period into the sixteenth century, the years encompassed by this study. Italian images of the Virgin Mary breastfeeding the Christ Child have a long history. The image is called here the Madonna lactans, but it is also known as Virgo lactans, its Latin name, and Galactotrophousa, its Greek title. The late medieval period was the peak of its popularity, but it was still desired, especially for devotional purposes, through the Renaissance period. The image appeared in a wide range of contexts and was viewed by nobility, saints, clerics, visionaries, ordinary folk, and reprobates alike. It adorned altarpieces, hospitals, street corner shrines, and was a favorite motif for private devotions. A diverse spectrum of cultural influences will be weighed. But first insight about the Madonna lactans image's beginnings and how scholars perceive the image provides a foundation for my thesis. The motif has the distinction, according to Dorothy Shorr, of having the longest continuous history of all the Madonna types. ${ }^{1}$

\footnotetext{
${ }^{1}$ Dorothy C. Shorr, The Christ Child in Devotional Images in Italy During the XIV Century, (New York, G. Wittenborn,1954), 58.
} 
One of the most thorough histories of the early formation and derivation of the image type was compiled by Victor Lasareff. ${ }^{2}$ He and subsequent scholars tell us that the first extant image of the Virgin Mary is a fresco in the catacomb of Priscilla in Rome, dated between the second and fourth century (fig. 1). It is also the first Madonna lactans. ${ }^{3}$ The Virgin in the catacomb image is seated and her semi-recumbent Child at once nurses and turns his head to gaze at the spectator. The informal composition exudes a natural, human quality as though observed directly from life. Lasareff concluded that considerable numbers of identical subjects existed in Early Christian times. "From this Hellenistic source the Galactotrophousa type, here pure genre, might easily have passed into Christian art both in the West and the East." ${ }^{4}$ The motif was likely adapted from the Egyptian group of Isis nursing Horus. Coptic paintings of the image from the sixth and seventh centuries can be found on the monastery walls of Bawit, in Lower Egypt, Saqqara, and in Upper Egypt. ${ }^{5}$ It is exciting to read a reference to a painting of the image in a letter written by Pope Gregory. He referred to a nursing Madonna in an epistle written to Emperor Leo the Isaurian $(717-741)$ in the eighth century. The letter reads, “. .. and also the images of his Holy Mother holding in her arms our Lord and God and nourishing him with her milk." ${ }^{6}$ The emphasis upon Mary's status as the Holy Mother is noteworthy, as is Pope Gregory's allusion to nourishment. Christ's humanity and Mary's role in his nourishment will be key considerations when we examine the image's meaning to viewers. But to return to our thread of its history, we know of Coptic

\footnotetext{
${ }^{2}$ Victor Lasareff, "Studies in the Iconography of the Virgin," The Art Bulletin 20 (1938): $26-36$.

${ }^{3}$ The catacomb fresco had been dated to the second century by scholars some years ago. See Shorr, 69 and Lasareff, 27. Miri Rubin assigned it to between the second and fourth century. Miri Rubin, Mother of God, A History of the Virgin Mary (New Haven: Yale University Press, 2009), see color plate section, leaf 2.

${ }^{4}$ Lasareff, 28.

${ }^{5}$ Lasareff, 29.

${ }^{6}$ Lasareff, $30-35$.
} 
miniatures from the British Museum and the Morgan collection dating from the ninth and tenth centuries respectively. They depict the Christ Child in an upright pose reminiscent of Horus in the Egyptian group. ${ }^{7}$ A ninth-century wall painting in which the nursing Christ Child is again semi-recumbent with his head turned to the right, is found in the cave church of the Pantokrator on the isle of Latmos, affirming its Greek presence. In fact, Lasareff points to several examples in Greek provinces and countries of the Christian East as evidence of its Greek popularity. A Virgo lactans images decorates the Omorphi church on the island of Aegina where a Nativity scene fresco, dated to 1289, depicts the Virgin nursing the swaddled Christ Child. Lasareff offers a number of other examples of the Virgo lactans subject including a 1323 Armenian Gospel book illustration, one in the frescoes of Peribleptos by a Byzantine painter, and two Greek icons - one in the chapel of St. John in the monastery on Mt. Sinai and the other at Karyas on Mt. Athos, both in poor condition, making accurate dating problematic. Our scholar concludes that there can be no further doubt “.... [T] hat the Virgo lactans type was well known in the art of the Christian East and also, though to a far less degree, in the art of Byzantium." ${ }^{\prime 8}$ From the twelfth century onwards the Madonna lactans is found in both painting and sculpture in Europe, particularly in Italy. Emphasizing the Byzantine introduction of the motif, Lasareff traced Italian origins in the dugento to Venice and Sicily, two outposts of Byzantine culture for Italy. ${ }^{9}$ One of the earliest Italian versions is a mosaic on the façade of Rome's S. Maria in Trastevere, dated to the thirteenth century (fig.2). The Rome Madonna is formally enthroned as a queen, exhibiting Byzantine and Coptic influences, and the Child is mature.

\footnotetext{
${ }^{7}$ Lasareff, 29. Brit. Mus. 7021, fol. Ir and Morgan collection, MS. no. 50, frontispiece.

${ }^{8}$ Lasareff, $29-33$.

${ }^{9}$ Lasareff, 35
} 
The Eastern derivation of the image is important when considering the variations of representation we witness in the Madonna lactans. In the trecento, the image retained the symbolic aspects of its Byzantine origins. In fact, it could be argued that the Madonna lactans long retained qualities of the image-centered theology developed in Eastern Christianity, where-by an icon was thought to have possessed some of the power of its divine prototype. Hans Belting asserted that the Eastern icon, which "was open to a personal manner of viewing, one that sought $\mathrm{a}[\mathrm{n}] \ldots$ inner reality through its visual experience, ... and a means to an end to make the invisible visible," ceased to exist in Byzantium after the Turkish conquest of 1453. "The art of the icon had no further development, but it had an afterlife.... As of the thirteenth century it had a second history, but now in Western art." ${ }^{, 10}$ As we shall see, some late medieval and Renaissance viewers' response to the image reflects this Eastern ideology. The image was a means to an end or a conduit to the divine.

While Lasareff offers a fair number of early examples, the number of nursing Madonna images grew considerably in the fourteenth and fifteenth centuries, particularly in Italy. As Christ's humanity was emphasized in period sermons and texts, and as the natural bond between Mary and the Christ Child became more obvious in images of the quattrocento, the viewer's emotional response to it becomes noticeable. We discover a personal interaction with the image as spectators' life experiences become part of their devotional experience. Furthermore, in the first quarter of the sixteenth century the image again experiences a bit of a resurgence, especially in the form of small devotional works. Individuals are the patrons of it and the duplication of it speaks to demand. The

\footnotetext{
${ }^{10}$ Hans Belting, Likeness and Presence:A History of the Image before the Era of Art (Chicago: University of Chicago Press, Chicago Press, 1994), 27.
} 
intimate encounter with the image is evident in the small size and the close range at which it would have been viewed. Certainly the amplified numbers in the late fourteenth, fifteenth, and early sixteenth centuries raise some questions. This dissertation will attempt to find answers to these questions: What religious, spiritual, cultural, and historical currents influenced the multiplication of the image? In light of medieval attitudes toward breastfeeding and in light of cultural circumstances, both of which drove the practicalities of feeding infants, what did viewers comprehend in the image? Furthermore, what connections can be made between devotional activities in which people engaged with the Madonna lactans and general trends in Marian devotion? Was the image perceived as a something more than a pleasing representation? Did people perceive power in it, either as a conduit to the divine or as having the efficacy of a sacrament? Was the nudity in the image provocative to viewers? What did the image communicate to different audiences in various contexts? These questions lead us to attempt to discover viewer reception and response to the image, which is a chief focus of this dissertation.

Reception and response theory's primary focus falls on the viewer and the process of gazing and seeing rather than on the artist or the art work. Accordingly the viewer holds the interpretative power. Although this seems self-evident, it must be acknowledged that individual response to images would be as varied as the individuals themselves. One influential solution is a study of interpretive communities, first conducted by Stanley Fish in the late 1970s. ${ }^{11}$ To paraphrase, Fish claimed that we

\footnotetext{
${ }^{11}$ Stanley Fish, Is There a Text in this Class? The Authority of Interpretive Communities (Cambridge, MA: Harvard University Press, 1980). Fish's analysis was about text and its meaning. For our purposes, we shall apply the theory to images. Thus, the reader will become the viewer.
} 
interpret [images] because we are part of an interpretive community that gives us a particular way of reading an [image]. When describing how different people come together to form such a community, Fish explained, "If the understanding of the people in question is informed by the same notions of what counts as a fact, of what is central, peripheral, and worthy of being noticed - in short, by the same interpretive principles the agreement between them will be assured ..."12 Trying to determine what a particular motif means to a group of viewers is helped by applying this theory. For instance, Dominican nuns in a particular convent at a determined period of time might form such a community. Hence a shared set of certain interpretive principles binds these interpretive communities together and informs their reading of the image. Our task is to uncover thoroughly the shared set of principles, keeping in mind that because the community comprises individuals, the interpretation cannot be completely uniform. An application of the interpretive community model will aid our inquiry into audience reception and response.

Reception and response theory tends to remove the artist from the experience of viewing artwork because it places interpretation on the viewer. Because I think there is a bit of a dance between the artist and the viewer, I want the artist in the equation. Michael Baxandall shed light on the issue, saying of a religious painting, "The painting is the relic of a cooperation between [the artist] and his public: the fifteenth-century experience of the [artwork] was an interaction between the painting, the configuration on the wall, and the visualizing activity of the public mind - a public mind with different furniture and

\footnotetext{
${ }^{12}$ Fish, 337.
} 
dispositions from ours." ${ }^{, 13}$ Baxandall's term relic is an accurate one in that it underscores the concept that the painting is the tangible or corporeal thing that stimulates or records the spiritual, devotional activity. Note Baxandall used the term "visualizing activity," instead of "viewing activity" and cautioned that the viewer's disposition is different from ours. Period texts directed visualizing activity as a form of meditation. Late medieval and Renaissance people understood that the physical senses engaged the spiritual senses, and they believed gazing at religious images was a conduit to the divine. Hans Belting's meticulous study shed light on viewers' responses to images through the medieval period. Belting proposed that the medieval viewer experienced "a recognition of the cult image not as an aesthetic illusion or as a work of an artist but as a manifestation of a higher reality - indeed, as an instrument of supernatural power." ${ }^{" 14}$ As an instrument of supernatural power, medieval people believed they were gazing at a channel to the divine. More than merely looking at the image, they interacted with it. The reciprocity of art and viewer is intriguing, and the investigation of this element is integral to grasping spectators' reception and response. The spectator is as essential a component of the artwork as the thing itself. To discover how the image affected the viewer is to learn of the image's vitality and the place it held in the cultural milieu.

The image is a religious subject. It is (in our period) generally more iconic than narrative; thus one assumes it had a devotional purpose, although we shall find exceptions. Discovering the function of a work of art and viewers' reception and responses to it depends on the analysis of myriad factors. We shall apply a wider

\footnotetext{
${ }^{13}$ Michael Baxandall, Painting and Experience in Fifteenth-Century Italy: A Primer in the Social History of Pictorial Style (Oxford: Oxford University Press, 1972), 48.

${ }^{14}$ Belting, 47.
} 
investigation of cultural, social and religious aspects of the society in which the artworks were made and viewed. The findings in other branches of social and historical inquiries will enrich ours. The focus on the mechanics of everyday life provides a rich framework for a better understanding of how people not only viewed the Madonna lactans image but how they used and interacted with it. Hence, religious ritual, family patterns, social status structures, and attitudes about the body and eating are important to our analysis. For instance, the grand festival, described in record books for centuries, has just as much bearing on our study as the unnoticed, mundane devotional activity, which was as ordinary as breathing. A "thick description" of culture will construct a comprehensive picture and will more thoroughly enlighten our analysis. ${ }^{15}$

The scholarly literature that was most significant to this research also stimulated new questions about the Madonna lactans. These scholars offered an analysis of the connection between art, culture, and religion in the late medieval and Renaissance periods, which is vital to the study of people's response to the nursing Madonna image. A portion of William R. Levin's informative studies concerns the function of a Madonna lactans image that adorned the entrance of a fourteenth-century Florentine charitable institution, the Compagnia di Santa Maria della Misericordia, which operated an orphanage. ${ }^{16}$ The lunette relief by Alberto Arnoldi portrays an intimate moment in which the Christ Child reaches for his mother's breast to nurse (fig. 1.1). Levin concluded that

\footnotetext{
${ }^{15}$ Ethnographer Clifford Geetz wrote about analyzing culture by not only applying observation and description, but also an interpretation of signs to gain meaning of actions, images, and ritual within a symbolic system. A 'thick description' approach considers all possible meanings. Clifford Geetz, "Thick Description: Toward an Interpretive Theory of Culture," in The Interpretation of Cultures (New York: Basic Books, 1973), chapter 1.

${ }^{16}$ William R. Levin, "Studies in the Imagery of Mercy in Late Medieval Italian Art," (Ph.D. diss., University of Michigan, 1983), 546 - 709. "Advertising Charity in the Trecento: The Public Decorations of the Misericordia in Florence," Studies in Iconography, 17 (1996): 215 - 310.
} 
this Madonna lactans image must have been a source of comfort for desperate parents who were compelled to give their children over to institutional care. The image, he asserted, inspired hope and assured parents that their children would receive the same care the Virgin gave her Son. Levin's exploration of the late medieval Italian Madonna lactans as an image of mercy and charity was an invaluable foundation for my research about how the image was received. He wrote, "Together the two figures personified neighborly love. ${ }^{, 17}$ Dr. Levin generously shared his findings and served as an advisor on my dissertation committee, and I am the grateful beneficiary of his considerable expertise.

Carolyn Walker Bynum's scholarly contribution investigated late medieval women's piety by examining mystics' visions and the religious significance of food. ${ }^{18}$ Her exhaustive research explores food asceticism practiced by late medieval Christians, especially women. She explained how rigorous fasting was a means to intense eucharistic devotion. "In renouncing ordinary food and directing their being toward food that is Christ, women moved to God ... by becoming the suffering and feeding humanity of the body on the cross, the food on the altar." ${ }^{, 19}$ In visions, fasting mystics saw themselves nursing at the breast of Christ. Their hunger was both acutely physical and intensely spiritual. Bynum concluded that women found control over their bodies, in relation to a spiritual union with God, a source of power. "Voluntary starvation, charitable food distribution, and eucharistic devotion were all means by which women controlled their social and religious circumstances quite directly and effectively ...

\footnotetext{
${ }^{17}$ Levin, “Advertising Charity," 275.

${ }^{18}$ Carolyn Walker Bynum, Holy Feast Holy Fast: The Religious Significance of Food to Medieval Women (Berkeley: University of California Press, 1987).

${ }^{19}$ Bynum, Holy Feast, 5.
} 
women's food practices frequently enabled them to determine the shape of their lives."20 Bynum's research about complex ascetic practices provided a framework for my analysis of visionaries' devotion to the nursing Madonna. Additionally, her work informed aspects of my probe into medieval people's understanding of the icon's connection to the Eucharist.

Miri Rubin provided an immensely valuable resource. The recently published Mother of God: A History of the Virgin Mary is a comprehensive study. ${ }^{21}$ The book has both great breadth and depth. It encompasses a wide range of geographical regions and chronologically proceeds from ancient times to about 1600 . The author consulted a wide range of art, music, poetry, theology, scripture, and period legends. Rubin's ambitious undertaking seeks to situate Mary in the cultural context of both Western Europe and other world cultures. She asserts, "It is impossible to imagine the history of Europe, or to understand many world cultures, without the meaning of Mary." ${ }^{, 2}$ Unlike previous Marian surveys, Rubin investigated Mary in Africa, Asia, and the New World. She also considered Islam's "Maryam" and the polemical encounters between Jews and Christians about Mary. The author's treatment of Mary's milk and representations of the nursing Madonna are not extensive, but open new avenues to pursue. Rubin's exhaustive research is a rich resource and a stimulus for inquiry into numerous aspects of Marian devotion.

Although he did not focus on the Madonna lactans, Michael Camille's insights about medieval people's visual experience when they gazed at images, inspired questions

\footnotetext{
${ }^{20}$ Bynum, Holy Feast, 220.

${ }^{21}$ Miri Rubin, Mother of God: A History of the Virgin Mary (New Haven: Yale University Press, 2009).

${ }^{22}$ Rubin, xxvi.
} 
about how medievals "saw" the nursing Virgin. ${ }^{23}$ Camille explained that art from the Middle Ages is best understood when a medieval person's perspective is applied. "[F]or the Gothic period it is indeed possible to discern what art historians have called a period eye. ${ }^{~} 24$ Emphasizing the point, he encouraged the study of these images "through the eye as the medievals understood it - a powerful sense-organ of perception, knowledge, and pleasure. ${ }^{25}$ Perception, knowledge, and pleasure could be interpreted several ways, but Camille distinguished "spiritual" from "corporeal" vision, clarifying: "[M]ystical [vision] entailed the pure and naked seeing of divine reality. ${ }^{, 26}$ Furthermore, the late art historian's insights about how medieval people interacted with religious images, in light of the period emphasis on the consecration of the bread into the Body of Christ, triggered my thinking about the altarpiece adorned with the nursing Madonna as a visual backdrop to the Elevation of the Host. Camille reasoned that, "The notion of the 'real presence' in eucharistic practice must have deeply influenced people's perception of images, for here a visual thing was itself capable of becoming and not just signifying its prototype." 27 This fascinated me. His observations were a starting point - the beginning of an inquiry into the possibility that the altarpiece image not only signified being fed, just as the Eucharist fed believers, but that it became nourishment endowed with sacramental value as well.

Megan Holmes explored the Renaissance application of naturalism to the image and the erotic reading it produced. Additionally, she considered how the image related to

\footnotetext{
${ }^{23}$ Michael Camille, Gothic Art, Glorious Visions (Upper Saddle River: NJ, 1996), 15.

${ }^{25}$ Camille, Gothic Art, 11.

${ }^{26}$ Camille, Gothic Art, 17.

${ }^{27}$ Michael Camille, The Gothic Idol: Ideology and Image Making in Medieval Art (Cambridge and New York: Cambridge University Press), 1989.
} 
the cult of the Virgin's milk-relic. ${ }^{28}$ Her chapter narrows in on the subject of the Madonna lactans and is both an important resource and a point of departure. Her premise is that "when a premium was placed on naturalism in the visual arts" the Madonna lactans image "became too disruptive . . threatening [its] sacred status."29 Holmes's observations prompted my investigation into Renaissance reception to the image. Her section on the totemic value of milk relics and Marian milk shrines was informative and helpful. It is among the few scholarly treatments of the subject. Holmes found that the relationship between the milk relic and the Madonna lactans image appears to have "been close" within the Tuscan Montevarchi region. She determined that the image at the relic shrine she examined validated the relic and provided a focus for devotion.

Jonathan K. Nelson was instrumental in organizing a symposium in 1998 entitled Suor Plautilla Nelli (1523 - 1588) The First Woman Painter of Florence, the proceedings of which were published as the first scholarly interest in the nun-artist since a small study was published sixty years earlier. ${ }^{30}$ In 2008 Nelson edited an anthology about Nelli. ${ }^{31}$ I became interested in Nelli's work when I came upon her small drawing of a nursing Madonna. None of the Nelson scholars addressed the Madonna lactans drawing, but they provided insight into Nelli's conventual life, her painting commissions, and her loyalties to the convent's Savonarola spirituality. The scholarship edited by Nelson furnished me

\footnotetext{
${ }^{28}$ Megan Holmes, "Disrobing the Virgin: The Madonna Lactans in Fifteenth-Century Florentine Art," in Picturing Women in Renaissance and Baroque Italy, eds. Geraldine A. Johnson and Sara F. Matthews Grieco (Cambridge: Cambridge University Press, 1997).

${ }^{29}$ Holmes, 178.

${ }^{30}$ Jonathan Nelson, ed., Suor Plautilla Nelli (1523 - 1588): The First Woman Painter of Florence (Fiesole: Cadmo, 2000). See also Giovanna Pierattini, Suor Plautilla Nelli, pittrice domenicana (Firenze: Convento S. Maria Novella, 1938).

${ }^{31}$ Jonathan K. Nelson, ed., Plautilla Nelli $(1524$ - 1588) The Painter-Prioress of Renaissance Florence (Syracuse: Syracuse University Press), 2008.
} 
with foundatonal material to begin an investigation about this prioress-artist and her drawing of the Seated Madonna Nursing.

These seminal works of scholarship gave answers, formed questions, and left open new areas to explore. The chief questions this dissertation seeks to answer are: If the Madonna lactans adorned charitable institutions, church altarpieces, nuns' cells, peoples' bedchambers, pocket-sized plaquettes, and roadside shrines what did people perceive when they gazed at it? Further, I ask: If late medieval vision enabled devotees to access the divine, did people comprehend a channel to God when they prayed before the image? Did the image have the efficacy of a sacrament? How did different communities respond to it? Ultimately, how did people engage with the image of Mary nursing her Son?

In what follows I seek to discover answers by combining an examination of the period texts, sermons, legends, rituals, scripture, and new scholarly analysis of historical context with a close examination of the image of the Madonna nursing her Son. The image divulged so much.

Chapter one is an investigation of period attitudes about breastfeeding, the widespread practice of employing a wet nurse, and the implications of the Madonna lactans image in the context of convents, charitable institutions, and churches. We find the nursing Madonna image was often commissioned by the Church, engaging the image to punctuate its sermons advocating maternal feeding, yet the majority of viewers did not heed the images' intended sacerdotal message. Further, charitable institutions saw a rise in its population of orphaned and abandoned infants. A Madonna lactans relief adorned 
the entrance to the Misericordia and Levin speculated that the image advertised the charity available inside and provided comfort for desparate parents in need of that charity. During this period of famine, disease, and poverty orphanages employed record numbers of wet nurses to feed their foundlings. I suggest, while not an intended audience for the image, the nursing Madonna might have resonated with the wet nurse as well. We know of cases in which the wet nurse also entrusted their children at institutions. The balie might have been consoled by the nurturing Madonna also.

Chapter two delves into Italian Marian image-driven devotional practices and the consequential connection to devotion to the Madonna lactans. There was a thriving cult dedicated to Mary's milk relic, and Madonna lactans images provided credence and devotional structure to the relic. The people who flocked to relic shrines sought the miraculous power believed to be available there. Public devotion was theatrical; private devotion was deeply personal, but both depended upon images to drive their activities. Yet neither the high or low quality of the image affected fervor. It was the power of Mary's role as intermediary to God that attracted people to her. We discover that medieval and Renaissance Italians enlisted her help during crowded festivals and in the intimacy of their bedchambers. They rubbed small relief plaquettes, perhaps hoping to release talismanic power. People felt themselves to be privileged with a direct connection to God because the Marian image, before which they prayed, was imbued with mystical power.

Chapter three scrutinizes late medieval peoples' response to the image as an altarpiece subject. It served as a backdrop for the dramatic consecration ritual at Mass, and acted as a sacramental image. Medieval people received communion infrequently; 
instead they engaged in spiritual communion, a practice in which gazing at the Host was tantamount to eating it. In this sacred context medieval people believed vision was a powerful sensory activity and that it connected them to a divine reality. Thus when people stared at the elevated Host, they believed they received the Body of Christ. Period monastic spirituality - especially Franciscan spirituality - placed great emphasis on Christ's humanity. Because of the flesh she shared with her Son and the milk she offered to nourish him, the nursing Madonna drew attention to that humanity. I suggest that the image of the nursing Virgin looming behind the Elevation of the Host ritual, provided people with a visual allusion to communion and endowed them with the efficacy of a sacrament. Hugh of St. Victor wrote De sacramentis in the twelfth century. He defined a sacrament as “. . . a sign containing within itself some invisible and spiritual grace. . ."32 The image of Mary feeding her Son was much more than a picture - it was a sign that graced those who gazed upon it, feeding them sacramentally.

Chapter four analyzes the reception of the Madonna lactans image for Renaissance Italians. I propose that the disruptive or prurient reading Holmes suggested for the image, due to period premiums placed on naturalism in the visual arts, did not affect viewers. Indeed, the sacred message was preserved because of Mary's anatomical asymmetry, the sacred signifiers that surrounded the image, and the fact that breastfeeding was a common sight and was not considered indecent. The chapter also investigates how nuns, as brides of Christ, interacted with the image. Visionaries imitated the nursing Virgin in a meditative state. They contemplated the image in their private cells, imagining nursing Christ or being fed by him. They longed for intimacy

\footnotetext{
${ }^{32}$ Hugh of Saint Victor, Hugh of Saint Victor On Sacraments of the Christian Faith (De sacramentis), trans. Roy J. Deferrari, I, IX, 2 (Cambridge, MA: Medieval Academy of America, 1951), 155.
} 
with the divine. Dominican nun Suor Plautilla Nelli wished for the same intimacy. She risked going against her convent's strict Savonarolan warnings about how Mary was to be attired in art, to draw the image for her private devotion. Finally, the image's implications as an intercessory tool for a fully engaged audience are considered. We discover that small devotional Madonna lactans images of the early sixteenth century reveal an invitation from Mary and the Christ Child. Their gestures and glances invite viewers to partake of the merciful breast being offered. I suggest it was an emotional experience for viewers to be so personally included. We consider Double Intercession images, which further underscore the offer of mercy featuring Mary and her grown Son. Mary indicates her breast as Jesus shows the Father his wounds in a plea on behalf of their faithful followers. A painting's inscription reads, "Because of the milk I gave you, have mercy on them." By virtue of her status as a nursing mother, Mary intercedes for people in need.

The Virgin Mary had an ardent, even fanatical following in the late medieval and Renaissance period. The sustenance she lovingly gave her Son was extended to all humankind. She was beloved as a human mother, merciful ally, and nurturer of the Savior; her ability to intercede on behalf of her faithful followers was her most attractive quality. The nursing attribute symbolized all of those aspects of Mary. People understood the image to be a conduit to the divine, a way to receive sacramental grace, and an avenue for merciful intercession. Because of the sustenance she gave her Son, her requests would never be refused. 


\section{CHAPTER I}

\section{THE VIRGIN AND THE WET NURSE}

Advice in favor of maternal feeding historically outweighed advice supporting the hiring of a wet nurse. Yet in this chapter we shall discover that in late medieval and Renaissance Italy, many factors swayed the trend toward employing wet nurses. We shall find that the enticements of sex, vanity, status, and convenience had strong pulls. Much of the rhetoric advocating maternal feeding came from people in the service of the Church such as clergy and saints' biographers. The Madonna lactans appears in Churchsponsored hospitals, charitable institutions, convents, and places of worship. The Church used the image to reinforce their stance against hiring wet nurses and to promote superior behavior in all breastfeeding women. Here was an image of a temperate mother who abstained from sexual relations. The Church's objective was that audiences would see in the Madonna lactans the ideal example of motherhood and the beneficial loving bond that the Virgin Mary and her Son so obviously shared. We shall examine images that projected this bond, and we shall investigate a few instances in which the Church intentionally commissioned works of art to advance their ideology.

Furthermore, this chapter explores how medieval and early modern Italians viewed breastfeeding morally, medically, and socially. We shall examine period sermons 
and treatises giving medical, moral, and child care advice to appreciate what people would have been told about breastfeeding. Maternal feeding was promoted as the Christian thing to do in texts like the Lives of the Saints and paintings of the Birth of the Virgin. Additionally, copious numbers of wet nurses were employed by charitable institutions where the image adorned entranceways and hallways (figs.1.1 and 1.2) . These employees would have seen the image often. Just as the Madonna lactans provided comfort to parents who required institutional service for their children, the nursing Madonna image may have reassured wet nurses who experienced the anxiety of separation from their own babies when it became necessary to allocate their milk to the infant of a paying client. As Margaret Miles asserted, such images nourished women and "tacitly affirmed a wide spectrum of behavior, emotion, and experience." ${ }^{, 33}$ Certainly the business of feeding children encompasses a wide spectrum of behavior, emotion, and experience, and images depicting it similarly spoke to people in myriad ways. Images of the Virgin Mary's life furnished people with a reflection of their own experiences or a projection of an ideal. The Madonna lactans image was especially resonant for parents and for women employed to feed children.

The scene of a human mother nursing her divine Son was one of the most frequently portrayed themes in Mary's life during the period ${ }^{34}$ and was laden with symbolism. However, its most rudimentary reading was that of a mother engaged in an activity common to mothers or wet nurses. Since time immemorial mothers and wet nurses of every epoch and nation fed children at their breast many times a day. This

\footnotetext{
${ }^{33}$ Margaret R. Miles, Image as Insight (Boston: Beacon Press, 1985), 11 - 12.

${ }^{34}$ Dorothy C. Shorr, The Christ Child in Devotional Images in Italy During the XIV Century, (New York, G. Wittenborn,1954), 58.
} 
chapter begins our study of viewers' reception and response to the Madonna lactans image by applying the most straightforward reading - that is, that the image simply reminded beholders of Mary performing the basic act of breastfeeding. Let us first examine what medieval and Renaissance people were told about feeding their newborns.

\section{Philosophical Directives about Breastfeeding}

Opinions concerning breastfeeding one's own infant during the late medieval and Renaissance periods were neither reserved nor scarce. Yet, the recorded attitudes about breastfeeding during this era do not reflect the common cultural practices. In fact, the wet nursing profession, which was fostered by upper classes in antiquity and through the High Middle Ages, became increasingly prevalent among the Italian middle classes, and eventually even members of lower classes engaged wet nurses into the early modern period. $^{35}$

Medieval and early modern moralists and scholars were deeply influenced by their ancient predecessors' writings. Such Roman philosophers as Pliny, Plutarch, and Favorinus were unequivocal in their support of maternal nursing. They advocated that mothers of all classes breastfeed their own infants because they considered mothers' milk to be the most natural option. ${ }^{36}$ Latin author Aulus Gellius (ca. $125-180 \mathrm{CE}$ ) recounted a speech made by his contemporary, the philosopher Favorinus on the subject, for which

\footnotetext{
${ }^{35}$ Valerie Fildes, Wet Nursing: A History from Antiquity to the Present, (Oxford, UK, Basil Blackwell, Inc., 1988), 44; Shulamith Shahar, "Infants, Infant Care, and Attitudes toward Infancy in the Medieval Lives of the Saints," The Journal of Psychohistory 10, no. 3 (Winter, 1983): 289.

${ }^{36}$ Aulus Gellius, The Attic Nights of Aulus Gellius Vol. II, trans. John C. Rolfe (Cambridge, MA.: Harvard University Press, 1927), 353 - 361. Pliny the Elder, The Historie of the World: Commonly called the Natural Historie of C. Plinius Secundus, trans. Philemon Holland, (London: Adam Islip, 1634) Book VII. Plutarch, "The Education or Bringing up of Children (1533)," in Four Tudor Books on Education, trans. Sir Thomas Elyot (Gainesville, FL: Scholars' Facsimiles \& Reprints, 1966), $11-13$.
} 
Gellius' effusive praise confirmed both his admiration for the philosopher and his concurrence on the subject. ${ }^{37}$ While visiting a pupil to congratulate him on the birth of his son, Favorinus instructed the family about maternal feeding. The father of this noble family was of senatorial rank. Aulus Gellius quoted Favorinus' lecture:

'For what kind of unnatural, imperfect and half-motherhood is it to bear a child and at once send it away from her? To have nourished in her own womb with her own blood something she could not see, and not to feed with her own milk what she sees, now alive, now human, now calling for a mother's care? Or do you too perhaps think,' said he, 'that nature gave women nipples as a kind of beauty-spot, not for the purpose of nourishing their children, but as an adornment of their breast? ${ }^{38}$

Favorinus' emphatic speech against the practice of using a wet nurse is an indication of the common incidence of non-maternal feeding during the period. The practice of sending one's newborn off to a wet nurse immediately after it was born for a period of up to three years was well known to ancient societies, and it continued with increasing prevalence through the early modern period and beyond. ${ }^{39}$ Wealthy families were able to afford to bring a wet nurse into their home, a fact exemplified in a sacred narrative painting by Domenico Ghirlandaio (fig. 1.3). The artist presented the wet nurse in a sumptuous interior in his painting Birth of John the Baptist. Here the balia nurses the newborn John as his mother Elizabeth watches from her bed. A second nurse reaches for the baby. The presence of two wet nurses and the well appointed room are evidence of the family's affluent status. The interior boasts a grand coffered ceiling, elaborate decorative moldings, and luxurious furnishings. An allegorical figure glides into the room carrying a platter of fruit, symbolizing the elderly Elizabeth's miraculous fertility. The balia is seated on the floor, reminiscent of the Madonna of Humility lactans type,

\footnotetext{
${ }^{37}$ Gellius, $353-361$.

${ }^{38}$ Gellius, 355 .

${ }^{39}$ Fildes, 44.
} 
popular in the last quarter of the fourteenth century and the early years of the fifteenth century. ${ }^{40}$ The balia's position on the floor also signifies her lower status. We shall investigate the wet nurse and her low status in detail below.

Returning to Favorinus we again find he would not have approved of the wet nurses in St. John's birth scene. As with other writers of the period, his concern was for the critical bond of love and affection between mother and infant, the diminished quality of which surely resulted when a wet nurse was employed. For him, everything was riding on this initial bonding experience.

'For when the child is given to another and removed from the mother's sight the strength of maternal ardour is gradually and little by little extinguished, every call of impatient anxiety is silenced, and a child which has been given over to another to nurse is almost as completely forgotten as if it had been lost by death. Moreover the child's own feelings of affection, fondness and intimacy are centered wholly in the one by whom it is nursed, and therefore just as happens in the case of those who are exposed at birth, it has no feeling for the mother who bore it and no regret for her loss. Therefore, when the foundations of natural affection have been destroyed and removed, however much children thus reared may seem to love their father and mother, that affection is in a great measure not natural but merely courteous and conventional. ${ }^{41}$

Favorinus' speech reflects his concern that natural affection available to all through their mothers was being thrown away. Medieval writers followed their predecessors in both sentiment and emphasis.

\footnotetext{
${ }^{40}$ The Madonna of Humility is an image type in which the Virgin is seated on the ground or on a low cushion. The name probably reflects a conflation of the Latin words humilitas ("humility") and humus ("ground."). Humility and the maternal act of nursing are tied together in this Madonna lactans type dating primarily from the thirteenth and fourteenth centuries. The combination of her lowly posture and the act of suckling her own baby signifies the Virgin's humbleness and solicitude. The Madonna of Humility has been judiciously studied, so the type will not be examined here. The seminal work on the subject is by Millard Meiss. See Millard Meiss, "The Madonna of Humility: Origin and Development," in Painting in Florence and Siena after the Black Death (Princeton: Princeton University Press, 1951), 132 - 56. See also Georgiana Goddard King, "The Virgin of Humility.” The Art Bulletin 17, no. 4 (December 1935): 474 - 91. Shorr, 67 - 77. Beth Williamson, Madonna of Humility, Development, Dissemination and Reception (Woodbridge, UK: Boydell, 2009).

${ }^{41}$ Gellius, 361 .
} 
In his widely read and influential encyclopedic work De proprietatibus rerum (On the Properties of Things) composed in the mid thirteenth century, Bartholomaeus Anglicus wrote that breastfeeding was a sign of good mothering. His sections about infants and mothers were largely based upon Aristotle's and Galen's writings. ${ }^{42} \mathrm{He}$ observed that the mother was the best nurse because she would have the greatest love for the child. As in the ancient philosophers' writings, the benefit of the loving bond enhanced by breastfeeding one's own infant was explicit in Anglicus's writings. He wrote: "She conceived him voluptuously, carried him in her womb where he was nourished by her blood, she bore him in pain, and she loves him and kisses him. Because of her love her nursing is best, and the nursing helps crystallize maternal love." ${ }^{\text {"43 }}$ The wisdom was handed down from one age to the next. Several fifteenth-century Italian moralists took their cue from the philosophers who came before them, strongly advocating the practice of maternal feeding for the beneficial maternal bond. However, concessions and advice about hiring wet nurses seeped into moralists' writings.

Florentine humanist and historian Matteo Palmieri (d. 1475) wrote Della vita civile, a moralistic treatise, in which he encouraged drawing upon nature's perfect pairing, that of mothers feeding their own infants. ${ }^{44}$ He warned of a decrease in the

\footnotetext{
${ }^{42}$ Bartholomaeus Anglicus, On the Properties of Things: John Trevisa's translation of Bartholomøus Anglicus De proprietatibus rerum, a critical text, De Matre, Liber Sextus, Capitulum 7 (Oxford: Oxford University Press, 1975), 303. See also Shahar, 295. Fildes, 33. Mary Martin McLaughlin, "Survivors and Surrogates: Children and Parents from the Ninth to the Thirteenth Centuries," in The History of Childhood, ed. Lloyd deMause (New York: Harper \& Row, 1974), 147, n. 42.

${ }^{43}$ Bartholomaeus Anglicus, 303. See also Shahar, 295.

44 Matteo Palmieri, [Libro] Della vita civile: Trattato (Milan: Giovanni Silvestri, 1825), 10, http://books.google.com/books?id=AV1DAAAAYAAJ\&printsec=frontcover\&dq=della + vita+civile.

"La natura, perfetta produttrice di tutte le cose in nel ventre di ciascuna gravida, ha coadunato un sangue in vivificativa virtu a formare la creatura umana, e ministrato a quella infino al tempo del maturo parto come non piu necessaria in quel luogo, si dirizza alle parti superiori, cioe nel petto materno onde fuori di se il conveniente e naturale nutrimento possa somministrare alla nata creatura, non altrimenti che drento da se nel proprio ventre abbia fatto."
} 
natural bond and maternal love in the event that a child is put out to nurse, emphasizing that a consequence of hiring a wet nurse was that when the children are grown they would not have a close, loving relationship with their natural mothers. ${ }^{45}$ Palmieri's encouragement was visually advocated in nursing Madonna images. The close bond between Mary and her Child became increasingly evident in the images from the second half of the fourteenth century onwards. Artists began to focus on the warm relationship using affectionate gestures and eye-contact between the two figures to convey the mother-Son bond. This affectionate bond is exemplified in Tomasso del Mazza's painting from ca. 1390 Madonna and Child with Six Saints now in Atlanta's High Museum (fig 1.4). Although surrounded by six saints, Mary and Jesus are engrossed in each other only. Compare Tomasso's painting with an early fourteenth-century depiction of the nursing Madonna by Pietro da Rimini in which the bond is all but absent (fig. 1.5). The Christ Child stands to nurse at his mother's side. Mary's eyes are diverted; she is preoccupied by something in the distance and the Christ Child looks in the opposite direction. Mary's left hand supports him rather than caresses him, and her right hand does not touch her Son at all. It is as if the goal was to deemphasize their bond. The emphasis on the shared bond of love between the Christ Child and his mother was demonstrated in later paintings in which Mary's hands do nothing but embrace her baby, and Mary and the Christ Child gaze directly into each other's eyes. Similar to Tomasso's painting, is the Sienese example from the early fifteenth century by Gregorio di Cecco (fig. 1.6). In this painting, again mother and Child ignore their companions. They are surrounded by angels entertaining them with musical instruments, yet the interaction

\footnotetext{
${ }^{45}$ Palmieri, 12. "Quinci poi addiviene che cresciuti i figliuoli, non hanno nella madre uno amore stretto in unione di continuata dilezione...."
} 
Mary and Jesus share is reserved exclusively for each other. These Church-sponsored images, available for everyone's viewing, echoed the sentiment preached in sermons and written in moralists' texts. The message to live an honorable life and pass goodness down to one's progeny through high-quality, clean milk was crystal clear in both words and images. The image of the nursing Virgin was the church's billboard for good conduct.

It would not be the first time images of the Virgin were used to further the Church's agenda. We find there are many instances in which historians point to the Church's use of images as propaganda. We shall examine two examples. Hans Belting demonstrates the point with an icon and mosaic of the Virgin (although she is not nursing Christ) commissioned by Pope John VII (reigned $705-07$ ). In both images the imperially adorned Virgin is depicted in the vestments of an empress and a tall bejeweled crown. ${ }^{46}$ Belting proposed, "In Byzantium, where the emperors were present in person, such analogies usually were avoided, since they might give the impression that the emperor wished to relinquish power to heaven. But in the West, where the Eastern empire was a constant source of difficulty, the investiture of the Virgin's image with the insignia of power had already become a tradition." ${ }^{47}$ The pope is depicted kissing the Virgin's feet in both the icon and mosaic. The inscription on the mosaic reads "Sanctae Dei Genitricis Servus" (Servant of the Holy Mother of God). Here the bishop of Rome subordinates himself directly to the queen of Heaven. Belting adds, "The antagonism may demonstrate how icons, like murals before, provided an instrument of official

\footnotetext{
${ }^{46}$ Belting, 127. The icon to which Belting refers is "usually" called the Madonna della Clemenza and is in S. Maria di Trastevere. The mosaic is in Old St. Peter's also in Rome.

${ }^{47}$ Belting, 127.
} 
propaganda. The pope at the time was still de jure a Byzantine vassal. But de facto he was now ready to exert his power independently, at the command of the Mother of God."48 Pope John VII used the artwork to assert his shift in loyalty.

To demonstrate that the Church continued this practice, I shall offer a much later example. Thomas Busar wrote about a case in which the Church used art to further its ideology in the sixteenth century. ${ }^{49}$ Evangelicae historiae imagines, adnotationes et meditation, an illustrated book of Gospel meditations, commissioned by St. Ignatius, founder of the Society of Jesus, was written by Jesuit Jerome Nadal, with engravings by the Wierix brothers. Written in the 1570s, it was not published until 1594. Buser declared, "This use of art by the early Roman Jesuits was part of a conscious aesthetic program, which they employed at the time the book was written in a propaganda battle with the Protestants over the significance of martyrs. It was Counter-Reformatory art to be sure." ${ }^{, 50}$ Church-sponsored images were continually commissioned in order to advance its position on numerous subjects. Images speak volumes. In the many Church-sponsored Madonna lactans images like those by Tomasso del Mazza (fig. 1.4) and Gregorio di Cecco (fig. 1.6) examined above, it is reasonable to deduce that the Church wished to visually advance their position on maternal feeding and the loving mother-Child bond extolled in sermons, Church texts, and saints' biographies.

\footnotetext{
48 Belting, 127.

49 Thomas Buser, "Jerome Nadal and Early Jesuit Art in Rome," The Art Bulletin 58, no. 3 (September 1976): 424.

${ }^{50}$ Buser, 424. For a fuller discussion about the purpose of religious images, see chap. 3 below.
} 


\section{Breastfeeding in the Lives of the Saints}

Another source which positively exemplified maternal nursing was the Lives of the Saints. Breastfeeding practices in these writings were colored with language associated with maternal love, Christian exemplum, and God's will. An examination of these biographies reveals maternal nursing among saints' mothers was the norm.

Acta Sanctorum - commonly known as The Lives of the Saints - was compiled from 1643 through 1940 by the Société des Bollandistes. The Lives of the twelfth to the fifteenth centuries were written by contemporaries of the saints themselves and are considered historical hagiographies. ${ }^{51}$ These documents provide a view of existing cultural customs, and Shulamith Shahar credibly proposed that habits and traditions across all social classes can be gleaned from them. ${ }^{52}$ We shall examine three examples from the late medieval period.

The love and affection associated with nursing one's baby is a theme in St. Catherine of Siena's Vita. St. Catherine was the twenty-fourth child of twenty-five born to her parents. According to her Vita, she was the first child her mother nursed herself. St. Catherine's younger twin sister was given to a wet nurse to feed. The twin died soon afterwards. The sequence in which the hagiographer told the story was unfortunate because the implication that wet nursing failed to allow the twin to thrive is overt. In

\footnotetext{
${ }^{51}$ The historical hagiographies differ from the earlier, more legendary stories. Shahar, 282. For more about the hagiographical literature and the difference between historical writing and legends see Hippolyte Delehaye, Bollandist, The Legends of the Saints, Fourth Edition, trans. Donald Attwater (New York: Fordham University Press, 1962), xi-xx.

${ }^{52}$ Acta Sanctorum (Antwerp and Brussels: Société des Bollandistes, 1643-1940); Shahar, 281. Shulamith Shahar has scrutinized these documents to study infancy in the lives of medieval saints. She contends that the descriptions of childcare sometimes written by authors who relayed personal, first-hand anecdotal narratives reveal general customs. 282. Shahar did not use lives written more than a few decades after the saints' death for her study, so she examined only contemporary accounts. See Shahar, n. 4, 302.
} 
fact, many of St. Catherine's older siblings thrived at the breast of a surrogate. However, the hagiographer tied maternal nursing to Catherine's survival, writing, "It was God's will that it was the twin sister who was handed over to a nurse while Catherine was breastfed by her mother and thus survived. ${ }^{53}$ St. Catherine's Vita also reports that her mother admitted that favoritism and love prompted her to nurse Catherine: "[W]hen she saw it, the mother, Lapa, though loving tenderly all her male and female offspring, nevertheless loved more tenderly this female babe she had nourished with her own milk. ${ }^{, 54}$ Lapa held that the reason she nursed Catherine was because she loved her more than all the others.

Encouragement for mothers to nurse their own babies is clear in these lines about Frances of Rome (d. 1440), found in Acta Sanctorum: "She fed the sons that God had granted her not only with her milk (though she ensured that they did not lack for that, feeding them with her own breasts not with those of a stranger) but with the fear of God." ${ }^{, 55}$ Her hagiographer implied that the act of breastfeeding one's own infant was somehow in accordance with God's will. The fear of God was and still is associated with one's respect for God's wishes and a desire to do his bidding. The hagiographer made a point to emphasize "feeding [her babies] with her own breasts," but maternal nursing was not the norm for the nobility, the level of society occupied by Frances of Rome in

\footnotetext{
${ }^{53}$ Acta sanctourm. April III, 869. Quoted in Shahar, 295.

54 "Quod cernens Lapa mater (quae quamvis omnes filios et filias diligeret tenere.) hanc tamen qua [m] nutriebat, proprio lacte, diligebat tenerius.” Acta Sanctorum, April III, p. 879. My gratitude to Rev. Thomas Franxman, S.J. for his help with this translation.

${ }^{55}$ Shahar, 284. Acta Sanctorum, March II, 181.
} 
fifteenth-century Italy. ${ }^{56}$ Nursing one's own infant was more commonplace among lower echelons of society.

St. Peter Damian, for example, was born of parents of modest means and was to become one of the most notable spiritual reformers of his age. When he was born in Ravenna in the early eleventh century into a large, poor family, an adolescent sibling chided his mother for bringing another baby into the already crowded home and "throng of heirs. ${ }^{, 57}$ According to the story this sent their mother into a deep depression. She refused to nurse or care for Peter. His biographer, John of Lodi wrote, "In her despair, his mother wholly rejected her baby, weaning him before he had hardly begun to nurse, and refusing to hold or touch him with her own hands." ${ }^{58}$ Just as Peter was about to die from maternal neglect a compassionate servant, who had assisted at the child's birth intervened. The servant reproached Peter's neglectful mother asking, "How could a Christian mother behave as no lioness or tigress would do? If these mothers faithfully nurse their cubs ... how could human mothers reject children formed in the image of God and shaped in their wombs?"59 According to John of Lodi, Peter's mother recovered after the scolding, and she resumed nursing the future saint, who flourished under her care until he was weaned. What is of interest to this study is the servant's use of the term

\footnotetext{
${ }^{56}$ Frances of Rome (1384 - 1440) was born into a wealthy family and was married to a young nobleman, despite her wish for the religious life. She had three children, all of whom she nursed herself, refusing outside help. Devoted to serving the poor, she turned her home into a hospital. Upon the death of her husband she went to live among the association of oblates she founded and from then on dedicated her life fully to the underprivileged. She was canonized in 1608. Butler's Lives of the Saints, Second Edition, Vol. I., eds. Herbert J. Thurston, S.J. and Donald Attwater (Westminster, MD: Christian Classics, Inc., 1926 -1938), 529-30.

${ }^{57}$ Peter Damian's biographer John of Lodi was his contemporary and friend. Written shortly after his death, Peter Damian's Vita appears in J. P. Migne, Patrologia Cursus Completus, series latina (Paris: 1844-1864), 111 -146. See also McLaughlin, 103-104, 141.

${ }^{58}$ John of Lodi, in Migne, 115b; See also Acta Sanctorum Feb. II, p. 416: "Cum eius nempe mater iam filiorum videlicet haeredibus referta hunc genuisset extremum."

${ }^{59}$ Quoted in McLaughlin, 104.
} 
"Christian mother," as if nursing one's own infant had to do with one's practice of Christianity. The bold servant made a connection between Christian behavior and nursing one's baby.

Images did not always echo the narrative, however. Let us return to Ghirlandaio's painting The Birth of St. John the Baptist (fig. 1.3). In it St. Elizabeth does not nurse her own baby. The portrayal does not agree with our saints' biographies which tell us, at least for saints' mothers, maternal feeding was the norm. Antonio Pollaiuolo designed anembroidery of the Birth of St. John the Baptist, also depicting a balia in charge of the Baptist's feeding. ${ }^{60}$ Jacopo Tintoretto featured the wet nurse as the focal point in his version of John the Baptist's birth (fig. 1.7). Here the balia kneels with both breasts bared preparing to nurse, in the center foreground. The comfortable Venetian interior boasts marble patterned floors and a luxuriously draped bed, which along with the presence of a wet nurse, signifies the family's prosperity. Tintoretto's St. Elizabeth is very much in the background. Painted in the depths of shadow, she is a minor character, barely visible. Tintoretto's version of the story does not coincide with the behavior praised in the Lives of the Saints.

However, it is noteworthy that images of Mary's birth typically do not include a wet nurse. ${ }^{61}$ The Birth of the Virgin paintings frequently follow the maternal feeding model represented in the Lives of the Saints. For example, the subject was painted by Pietro Lorenzetti (fig. 1.8) and Domenico Ghirlandaio (fig. 1.9). The two maids in Pietro

\footnotetext{
${ }^{60}$ Holmes, 188 .

${ }^{61}$ I have found only one exception. It is an English tapestry, which hangs in the nave of the Strasbourg Cathdral in France. In it a wet nurse is seated next to St. Anne's bed, nursing the newborn Mary. The designer and date are unknown. http://commons.wikimedia.org/wiki/File:Tapestry_Birth_of_the_Virgin_Strasbourg.jpg.
} 
Lorenzetti's painting prepare a bath for the infant Mary. They occupy the interior of a prosperous family. The room has mosaic tiled floors, ample furnishings, and groin vaulted painted ceilings (the stars of heaven dot the ceiling). St. Anne is prominently featured in the central panel of Lorenzetti's triptych, unlike the obscured St. Elizabeth in Tintoretto's work. Lorenzetti's St. Anne - Jesus' grandmother - is the mother who did not hire a wet nurse. Tintoretto's St. Elizabeth - the mother who did hire a wet nurse - is in the background of his painting. It is not my suggestion that the artists were making a comment on wet nurses. Lorenzetti's central placement of St. Anne was almost certainly an effort to honor her exalted status as a direct relative of Christ. Additionally both artists likely followed other sacred narrative models. Let us inspect the themes executed by the same artist. Giovanni Tornabuoni commissioned Ghirlandaio to paint a series of frescoes depicting the lives of Mary and John the Baptist for the choir chapel in Santa Maria Novella in the late 1480s. Compare John's and Mary's birth scenes by Ghirlandaio. The two paintings are similar in that they reflect the artist's keen observation of detail and his adept use of consistent perspective. Both scenes are populated with sumptuously dressed women, some of which are members of the patron's family. ${ }^{62}$ Although Ghirlandaio situates Mary's birth in an even more opulent interior than John the Baptist's - designed by architect and furniture carver Giuliano da Sangallo $^{63}$ - the attendants prepare a bath, but none nurse the newborn Mary. It is

\footnotetext{
${ }^{62}$ Ghirlandaio likely localized the interior by painting a resemblance of the patron's palazzo. Members of the family are included as spectators of the sacred moments. Giovanni Tornabuoni's daughter Ludovica is among them.

Roann Barris, Italian Art in the Fifteenth Century, http://www.radford.edu/rbarris/art216upd2012/15th\%20century\%20Italian\%20arts\%20S11.html.

${ }^{63}$ Frederick Hartt, The History of Renaissance Art: Painting, Sculpture, Architecture, $4^{\text {th }}$ ed. (New York: Harry N. Abrams, Inc., 1997), 348.. The artist ran a thriving workshop in Florence. His most famous apprentice was Michelangelo, who joined the workshop in 1487 and "almost certainly assisted in the creation of these frescoes." Hugo Chapman, Domenico Ghirlandaio, The Birth of the Virgin, a pen and
} 
curious that Ghirlandaio's versions of the birth scenes have a wet nurse for St. John but not for the Virgin Mary. Again, Ghirlandaio may have followed narrative models, yet is it worth noting the iconographic differences. As the Lives of the Saints and the paintings of Mary's birth testify, breastfeeding one's own child was a requisite for the sanctity of motherhood. And the Saint of saints, Mary, was nursed by her own saintly mother, at least in portrayals of her birth from our period. Hence, St. Anne demonstrated the approved choice for feeding offspring in images that populated public churches, and St. Elizabeth - perhaps thought to have been a lesser saint - did not. Mary's example is so much more overt in art. The Madonna lactans features the act of nursing in no uncertain terms.

Moralists, philosophers, and hagiographers' stories all concur about the benefits of maternal feeding. Allowances were made for hiring wet nurses, but the writers only conceded the employment of this luxury under absolutely necessary circumstances, such as when the mothers' milk supply was wanting. ${ }^{64}$ Medical writers added to the conversation, usually using science as a basis for their points of view. Their knowledge was based, for the most part, upon their forefathers' scientific conclusions.

\section{Breastfeeding from the Medical Perspective}

Medical theorists and physicians wrote about the subject of breastfeeding in Ancient times; for good or for ill these theories would have a far-reaching influence on the medical theorists of the Middle Ages and early modern period. Ancient writer

brown ink drawing, The British Museum.

http://www.britishmuseum.org/explore/highlights/highlight_objects/pd/d/ghirlandaio, birth_of virgin.aspx.

${ }^{64}$ James Bruce Ross, "The Middle-Class Child in Urban Italy," in The History of Childhood, ed. Lloyd deMause (New York: Harper \& Row, 1974), 186. Ross cites San Bernardino and Maffeo Vegio as authors who made this concession. 
Claudius Galenus, born in Pergamos in Asia Minor in $131 \mathrm{CE}$, studied medicine at Alexandria. In $169 \mathrm{CE}$ he became Emperor Marcus Aurelius' personal physician. He wrote extensively on medical matters and left volumes for physicians to read and absorb for generations. Medieval and early modern physicians and practitioners relied heavily upon his writings, and according to his biographer and the translator of his work, Robert M. Green, M.D., many of Galen's thoughts and words are embedded in today's medical canon. Green admitted that some of what Galen wrote is inaccurate and might now seem absurd or trivial. Yet, Green credits Galen with being a thousand years ahead of his time, anticipating future discoveries. ${ }^{65}$ Chapter nine of Galen's Hygiene is devoted to breastfeeding. On some points, modern medical journals agree with Galen. For example he asserted that "nature herself planned for children, providing them mother's milk as a moist sustenance. And mother's milk is equally best for all children ..." ${ }^{\prime 66}$ On other points Galen's hypotheses did not withstand the test of time nearly as well. He was absolutely unyielding on the subject of sexual relations for nursing women. "I order all women who are nursing babies to abstain completely from sex relations. ${ }^{967}$ He reasoned that the menstrual flow is provoked by sexual intercourse, and during menstruation the milk no longer remains sweet. Furthermore, Galen allowed that the risk of conception is certainly present with sexual activity, and he wrote that there could be "nothing worse for the suckling infant because while pregnant, the best of the mother's blood goes to the foetus. Because of this the pregnant woman's blood becomes inferior and not only less,

\footnotetext{
${ }^{65}$ Robert M. Green, M.D. A Translation of Galen's Hygiene (Springfield, IL: Charles C. Thomas, Publisher, 1951), xiii.

${ }^{66}$ Quoted in Green, 24.

${ }^{67}$ Quoted in Green, 29. Pliny the Elder differs on this subject. "The milk of a woman who is giving suck will not become impure, if she should happen to become pregnant again by the same man." See Pliny the Elder, The Natural History of Pliny, Vol. II, trans. John Bostock, M.D. and H. T. Riley (London: Henry G. Bohn, 1855), Book VII, 152.
} 
but inferior milk collects in her breasts." ${ }^{68}$ This belief was not Galen's alone. St.

Augustine added prohibitions against nursing women engaging in sexual relations. ${ }^{69}$

However, Pliny the Elder (d. 79 CE) did not hold this to be true. "The milk of a woman

who is giving suck will not become impure, if she should happen to become pregnant

again by the same man."70 Despite Pliny the Elder, the conviction that intercourse during

lactation would corrupt the milk and reduce its supply was commonly held, and the belief

was passed along to medieval and early modern writers. The belief that premature

conception would harm both the embryo and the nursing baby because nutrients would be

divided between the two was widely held. ${ }^{71}$ The image of Mary, eternal Virgin, suckling

her Son, visually reinforced the prohibitions against intercourse during lactation. The

Virgin Mother of God was the perfect example of a nursing mother who refrained from

sexual relations. The image conveniently spoke for the moralists on this issue as well.

Like Galen, Soranus of Ephesus (98 - $138 \mathrm{CE}$ ) was a Greek physician of the

Roman Empire whose writings also had a direct influence upon future medical thinking.

He is often referred to as a gynecologist, and his publication Soranus' Gynecology gave

instructions to new mothers about feeding their newborns. He too denounced intercourse

during lactation. In addition to his like-mindedness about sexual relations spoiling the

milk, he added a different twist: "For coitus cools the affection toward the nursling by the

\footnotetext{
${ }^{68}$ Quoted in Green, 29.

${ }^{69}$ See William R. Levin, "The Practice of Wetnursing in Late Medieval and Early Renaissance Italy," Appendix B in "Studies in the Imagery of Mercy," 964, n. 4.

${ }^{70}$ Pliny the Elder, The Natural History of Pliny, vol. II, trans. John Bostock, M.D. and H. T. Riley (London: Henry G. Bohn, 1855), book VII, 152.

${ }^{71}$ See Shahar, 302, n. 12,“. . . omnino caveat a coitu quia sanguinem menstruum permiscet, \& lactis odordem corrumpit, eiusque quantitatum minuit. Fortassis autem $\&$ impraegnabitur, \& tunc quod in sanguine subtile est, ad nutrimentum embrionis redibit. Ipsius etiam empbrionis nutrimentum parum erit, eo quodalius lacte indigent; \& sic utrique nocumentum fiet." Vincent Burgundi Speculum quadruplex. Speculum doctrinal, edition de Benedictins de St. Vaast a Douai (1624). f. 1091.
} 
diversion of sexual pleasure and moreover spoils and diminishes the milk or suppresses it entirely by stimulating menstrual catharsis through the uterus or by bringing about conception. ${ }^{, 72}$ His advice is noteworthy because he was the first writer to address the sensual pleasure inherent in nursing a baby. This is addressed with a degree of frequency in modern writings on the subject, but at the time Soranus was alone in cautioning that the pleasure derived from intercourse would usurp affection toward one's infant. The subject is never addressed in medieval and early modern writings. ${ }^{73}$ Soranus was also unique in that he (erroneously) urged mothers to wait a few days before beginning to nurse their newborn. He advised that the baby should not eat the day after it is born because it is "yet full of maternal food." ${ }^{74}$ For subsequent initial days he urged the use of a wet nurse. He wrote:

From the second day on ... one should feed with milk of somebody able to serve as a wet nurse, as for twenty days the maternal milk is in most cases unwholesome, being thick, too caseous, [sic] and therefore hard to digest, raw, and not prepared to perfection. Furthermore, it is produced by bodies which are in a bad state, agitated and changed to the extent we see the body altered after delivery when, from having suffered a great discharge of blood, it is dried up, toneless, discoloured, and in the majority of cases feverish as well. For all these reasons it is absurd to prescribe the maternal milk until the body enjoys stable health. ${ }^{75}$

Soranus encouraged censure of those who recommend that mothers give their newborns the breast immediately. He discredited a few writers on this matter, and he called for

\footnotetext{
${ }^{72}$ Soranus, Soranus’ Gynecology, trans. Owsei Temkin, M.D. (Baltimore: Johns Hopkins Press, 1956), $92-93$.

${ }^{73}$ Moralists and humanists do not broach the subject of the physical pleasure inherent in nursing or the husband's psychological reaction to having to share his wife's body with his newborn, but modern-day scholar David Hunt presented the hypothesis that the practice of hiring a wet nurse may have been connected to the husband's desire to have his wife's body all to himself after the birth of their baby. The husband or other men typically took care of the arrangements for finding and hiring a wet nurse. The father of the newborn and the wet nurse's husband (called a balio) usually executed the contract. David Hunt, Parents and Children in History, The Psychology of Family Life in Early Modern France, (New York: Basic Books, Inc., 1970), 107.

${ }^{74}$ Soranus, 88 .

${ }^{75}$ Soranus, $88-89$.
} 
honey and goats' milk if a wet nurse was unavailable. The importance of colostrum (this first milk produced) was overlooked by most theorists until relatively modern times. ${ }^{76}$

Other misconceptions about breast milk persisted. The connection between blood and milk was confused in the minds of medieval and early modern people. It was believed that the menstrual blood (which discontinued its flow during pregnancy) became breast milk when it began to flow after the birth of a baby. ${ }^{77}$ The notion that there were veins connecting the uterus and the breasts had Hippocratic origins. ${ }^{78}$ Aristotle (384-322 BCE) wrote about the correlation between menstrual blood and lactation in his work Historia animalium. Aristotle's teaching on this was influential to those writing on the subject all the way into the eighteenth century. ${ }^{79}$ These ideas were passed along and can be seen in subsequent scientific and medical writings. For example, Avicenna's Canon of Medicine repeated this fact in the early eleventh century. ${ }^{80}$ In the twelfth century

\footnotetext{
${ }^{76}$ Le Leche League International, "What is Colostrum ? How Does it Benefit my Baby?" http://www.llli.org/FAQ/colostrum.html. After giving birth and even during the last days of pregnancy a woman's breasts produce colostrum. This special milk is yellow to orange in color and thick and sticky. It is low in fat, and high in carbohydrates, protein, and antibodies to help keep the baby healthy. The concentration of immune factors is much higher in colostrum than in mature milk. Colostrum works as a natural and $100 \%$ safe vaccine. It contains large quantities of an antibody called secretory immunoglobulin A (IgA). Colostrum is extremely easy to digest, and is therefore the perfect first food.

${ }^{77}$ The medieval thinking was not altogether in error. Certain components of breast milk come from blood. "[Lactocytes] are the cells that make the milk. Lactocytes [take] various components from the blood and convert them into specific milk components. Some of these components, such as vitamins and minerals, as well as certain infection-fighting immune factors, can be extracted basically intact from the mother's blood. Other components, however, such as casein proteins or the carbohydrate lactose, must undergo assembly in the lactocytes....The mixture of all these components is what constitutes milk." Sharon Donovan, The Visual MD: Bringing Health to Life, http://www.thevisualmd.com/health_centers/child health/mother_s_milk/the ultimate homemade meal. The thinking that veins connected the uterus and the breast was erroneous, however. The connection between blood and milk will be examined in greater detail in chapter three of this study, in reference to the Madonna lactans and the Eucharist.

${ }^{78}$ Hippocrates, Aphorism, trans. Francis Adams, written in 400 BCE, section V, 50. http://classics.mit.edu/Hippocrates/aphorisms.5.v.html .

${ }^{79}$ Fidles, 9.

${ }^{80}$ Mazharh Shah, The General Principles of Avicenna's Canon of Medicine (Karachi, Pakistan: Naveed Clinic, 1966), 286. Avicenna $(980-1037)$ was a medical writer born in Persia. His treatises were widely distributed and largely based upon Galen's works.
} 
Hildegard of Bingen wrote from a woman's perspective on this very female subject, and still the anatomy was confused. She stated:

When the woman receives seed from the man so that it begins to grow in her, then by that natural energy, too, the woman's blood it drawn up towards her breasts, and what was to become blood from food and drink now is turned into milk to nourish the child growing in the mother's womb. ${ }^{81}$

Not only was blood drawn up to the breasts, as Hildegard suggested, it was thought that menstrual blood was refined in the breasts. According to Bartholomaeus Anglicus's thirteenth-century writings, purification of the menstrual blood was considered to be one of the functions of the breasts. ${ }^{82}$ Maffeo Vegio added this elucidation of female anatomy to the body of literature:

... since nature, when the time of childbirth draws near, transmits blood, which causes unborn children to grow, to the exterior sources of milk [breasts], providing by a miraculous device that the children, once brought into the world, are not supplied with a different nourishment than they were fed upon when hidden in the body. ${ }^{83}$

Theories were bolstered by images. Leonardo da Vinci drew a diagram of the female anatomy in which veins connecting the uterus to the breasts are visible; the drawing undoubtedly reflected the view commonly held through the early modern period. ${ }^{84}$

\footnotetext{
${ }^{81}$ Hildegard of Bingen, On Natural Philosophy and Medicine: Selections from Cause et Cure, trans. Margret Berger (Cambridge,UK: D.S. Brewer, 1999), 50. Hildegard of Bingen is known as a mystic, composer, philosopher, and writer of botanical, theological, and medicinal texts. For an informative summary of scholars' disputes and debates about the authorship of some works attributed to her, see Berger, ix - xi.

${ }^{82}$ Bartholomaeus Anglicus, 233 -235.

${ }^{83}$ Vegio, 22.

${ }^{84}$ Leonardo da Vinci, Leonardo da Vinci: Disegni anatomici dalla Biblioteca reale di Windsor (Florence: Guinti Barbera, 1979), 16A.
} 


\section{The Mysterious Properties of Breast Milk}

Misconceptions occurred in theoretical writings about the properties of breast milk, and misinformation about how to test and analyze its quality can be found in medical literature. Medieval and early modern people believed that the properties of breast milk had a vital influence upon infants' character development and behavior and that the milk could transmit moral and intellectual qualities. There was, of course, no one more moral than the sinless anti-Eve, the Virgin Mary. In poetic praises of Mary's breasts, her milk was understood to have mystical properties, issuing not from her body, but from her moral virtues. For example in Bernardus Morlanensus' (Bernard of Cluny's) Mariale, he poetically praised Mary's milk, saying its mystical properties could extinguish lust: "May a drop flow from the breast of the glorious Virgin, may it send forth dew that extinguishes the heat of lust." ${ }^{85}$ In his work, De uberius B. Mariae Virginis, Bernard praised Mary's breasts and the milk that flows from them for their ability to defeat and weaken the savage enemy and thereby save us.

As pomegranates are wonderfully fragrant,

Their fragrance routing the savage enemy,

They weaken the deeds of the wicked,

They put forth nectar through the mouths of their flowers,

Saving us through all time.

They flow like cups of the vine

Running through the streams of the highest godhead. ${ }^{86}$

\footnotetext{
85 "Fluat stilla de mamilla gloriosae virginis, fundat rorem qui ardorem extinguat libidinis." Quoted inYrjo Hirn, The Sacred Shrine: A Study of Poetry and Art of the Catholic Church (London: MacMillan and Co., 1912), 535.

86 “... Velut mala Punicorum, Fragrant, halitus istorum, Fugantes hostem saevum,, Laxant gesta nefandorum, Stillant nectar per os florum, Salvantes nos per aevum. Fluunt ut vitis pocula, Currentia per
} 
Bernard's poems underscore medieval people's belief in the milk's ability to transmit qualities to the nursling, and the woman feeding the God-child must have had potent milk indeed. In this light, her character would have to be flawless. And people believed it was.

In the narratives about saints' mothers who breastfed their own babies recorded in the Lives, Shahar reported that time and again stories revealed that mothers feared the milk of a stranger would somehow transfer undesirable character traits to their babies. In contrast, these mothers felt their own virtues could be passed along in their breast milk. ${ }^{87}$ Therefore, both vices and virtues could flow through the milk from nurse to baby. Maffeo Vegio and his brother were fed by wet nurses at home, and each reportedly acquired his different traits from his nurse. Maffeo's brother Lorenzo "seemed to have the same features, the same expression and even the same walk [as his nurse]." Maffeo's nurse's modesty and reticence were passed to him, "as if I had imbibed with her milk her heart and spirit." ${ }^{88}$ The notion that physical characteristics and temperamental traits could be acquired through breast milk may have been handed down from Ancient theorists. Aulus Gellius in Noctes Atticae recounts Favorinus' perspective: "If the seed naturally has the ability to create resemblance of body and mind, milk has similar and no less strong properties ... Nothing contributes more to influencing mores than the character and the milk of the nurse. ${ }^{.89}$ In practice, however, parental pride in passing

rivul,a Summae deitatis.” Bernardus Morlanensis, De uberibus B. Mariae Virginis, quoted in Hirn, 535. I am grateful to Msgr. William F. Cleves's for his help with translations.

${ }^{87}$ Shahar, 296.

${ }^{88}$ Quoted in Ross, 186, from Vegio, De educatione, 25 - 26.

${ }^{89}$ Robert Etienne, "Ancient Medical Conscience and the Life of Children," trans. Michele R. Morris, Journal of Psychohistory IV, (1977), 148. For a slightly different translation see Gellius, 359. "And there is no doubt that in forming character the disposition of the nurse and the quality of the milk play a great part; for the milk, although imbued from the beginning with the material of the father's seed, forms the infant offspring from the body and mind of the mother as well." 
along familial virtues took a back seat to the perceived virtues of hiring wet nurses for one's progeny.

In Renaissance Italy, Venetian humanist Francesco Barbaro (ca.1390 - 1454) demonstrated that qualities were inherited through breast milk. In his On Wifely Duties he cautioned that noble women should suckle their own children. He wrote, "In this way the young infant will not imbibe corrupt habits and words and will not receive, with his milk, baseness, faults, and impure infirmities and thus be infected with a dangerous degenerative disease in mind and body." ${ }^{90}$ Michelangelo $(1475-1564)$ also revealed the thinking that milk carried character-shaping properties when he famously remarked to Vasari that his predilection for carving came from his wet nurse's milk, who was the wife of a stone-cutter. He said, “... [W]ith my mother's [wet nurse's] milk I sucked in the hammer and chisels I use for my statues." ${ }^{.91}$ Barbaro's perspective reflects a dread that undesirable traits would be transmitted; Michelangelo's statement reveals a positive contribution. In either case, with their progeny's traits, talents, and physical features at stake, the quality of the milk was of utmost importance to people.

Documents contain instructions for testing the milk and warnings against the use of animal milk. A female physician known as Trotula of Salerno, who likely occupied a chair of medicine at the University of Salerno, wrote about medical issues pertaining to

\footnotetext{
${ }^{90}$ Francesco Barbaro, On Wifely Duties, trans. Benjamin G. Kohl in The Earthly Republic: Italian Humanists on Government and Society, ed. Benjamin G. Kohl and Ronald Witt (Philadelphia: University of Pennsylvania Press, 1978), 223.

${ }^{91}$ GiorgioVasari, The Lives of the Most Eminent Painters, Sculptors and Architects, ed. Philip Jacks, trans. Gaston du C. de Vere (New York: The Modern Library, 2006), 326. Although Michelangelo used the word "mother" he is referring to his wet nurse in the village of Settignano, a locale rich in stone located near Florence where he was put out to nurse.
} 
women. ${ }^{92}$ Instructions for hiring a proper wet nurse are included in writings attributed to

Trotula; however, it is noteworthy that no text ascribed to her advised women to nurse

their own infants. Some believe her to be the author of Practica Puerorum, where the

following instructions for testing milk quality are recorded:

The first question for consideration, therefore, is the milk upon which the child is nourished, whether it be good, and this is determined as follows. For it should be good and of good odor and continuous, and this we learn in the following manner. Let the milk be placed upon a rock or a polished sword; if it stands after the manner of a crystal, it is good, but if after the manner of water, it is not good. ${ }^{93}$

Thus, the preoccupation with the larger issue of whether to hire a wet nurse or not does not appear to be a concern of this (probably female) writer.

Additionally, there were misgivings about feeding infants animals' milk based

upon what properties the milk would transmit. A child nourished by the animal's milk

\footnotetext{
${ }^{92}$ The University of Salerno had the first medieval medical school and was a connecting link between medical knowledge of "antiquity and that of the Renaissance and the Christian West." Benjamin Lee Gordon, Medieval and Renaissance Medicine (New York: Philosophical Library, 1959), 314. There exists scholarly debate about the attribution of Trotula's writings. Some medical history scholars are adamant about her credentials. For example, Trotula scholar Dr. H.P. Bayon of Cambridge University stated, "Trotula was one of the most significant of its [Salerintan School] writers, according to any test one cares to apply." Elizabeth Mason-Hohl, M.D. included Bayon's statement in her Forward to Trotula of Salerno, Diseases of Women: A Translation of Passionibus Mulierum Curandorum, trans. Elizabeth Mason-Hohl, M.D. (Los Angeles: Ward Ritchie Press, 1940), vii. See also Women's Lives in Medieval Europe: A Sourcebook, ed. Emilie Amt (New York: Routledge, 1993), 98. Luke Demaitre referred to her as "the mysterious Trotula" in his "The Idea of Childcare in the Medical Writings of the Middle Ages," in Journal of Psychohistory IV (1977), 464. Others identified her as "probably an obstetrician" and "the wife of a famous physician of Salerno, Johannes Platearius (c.1125)." See Benjamin Lee Gordon, 316. Valerie Fildes called her the author of two medieval manuscripts on the diseases of children and a book on the diseases of women. See Fildes, 32. Elspeth Whitney wrote, "'Trotula' was originally the overall title given to these anonymous works. Conditions of Women and Women's Cosmetics were probably written by men, but Treatments of Women was likely written by a practicing female physician, possibly named Trota." Elspeth Whitney, Medieval Science and Technology (Westport, CT, 2004), 171. I have given a representative sample of the diverse opinions on Trotula's writings. It appears skepticism is found in more recent scholarship, but all agree that a woman penned some of the extant texts.

93 "Incipit Practica Puerorum Passiones Puerorum Adhuc in Cunabulis Lacentium (Diseases of Children Still in the Cradle)" in Pediatrics of the Past: An Anthology, ed. John Ruhrah (New York: P.B. Hoeber, 1925), 24. The origin of the text is stated to be unknown in this anthology. Valierie Fildes attributed this text to Trotula. See Fildes, 32-33. Luke Demaitre called this text part of an anonymous treatise from the twelfth century. See Demaitre, 465.
} 
would consequently take on its features. In his book of good manners written in about 1350, Tuscan merchant Paolo da Certaldo warned that an infant, "nourished on animal milk does not have wits like one fed on woman's milk, but always looks stupid and vacant and not right in the head." 94 Paolo's statement is foolish now, but it must have had the weight of authority against using animal milk when he wrote it. The Tuscan poet Francesco da Barbarino warned, "Don't give the infant goat's milk, if you can avoid it, and even less, that of a bitch or sow, and avoid cow's milk ... (But, if necessary, I'll grant you ewe's milk)." 95 The poet left no explanation about the latitude for ewe's milk. The fact is there is evidence of a fair amount of animal milk use. ${ }^{96}$ Wet nurses sometimes supplemented their declining milk supply with animal milk, especially those hired by institutions. $^{97}$

\section{The Wet Nurse: Habits and Environment}

Leon Battista Alberti gave advice to expectant fathers even though he had no offspring of his own. He reminded fathers of Favornius' advice as reported by Aulus Gellius but conceded that a wet nurse was necessary when the mother cannot nurse. In line with other writers, he explained that the wrong wet nurse can damage the child. "She can incline him toward vices and fill his spirit with savage and bestial passions of anger, fear, terror, and with similar evils." 98 Alberti's conviction that the wrong wet nurse would pass along her vices to the infant was echoed emphatically by his contemporary

\footnotetext{
${ }^{94}$ Paolo da Certaldo, Libro di Buoni Costumi, ed. Alfredo Schiaffini, (Florence: F. Le Monnier, 1945$), 234$. http://books.google.com/books/about/Libro_di_Buoni Costumi.html. Quoted in Ross, 187.

${ }^{95}$ Francesco da Barbarino, Reggimento e costume di donna, ed. G.E. Sansoni (Turin: 1957), 195. Quoted in Ross, 187.

${ }^{96}$ For more about the use of animal milk for feeding infants see McLaughlin, 116 - 117. Fildes, 46, $145-7$.

${ }^{97}$ Levin, "Advertising Charity," 245 - 246.

${ }^{98}$ Leon Battista Alberti, The Family in Renaissance Florence: A Translation by Renee Neu Watkins of I Libri Della Famiglia. (Columbia, SC: University of South Carolina Press, 1969), 53.
} 
Matteo Palmieri, who used harsh language when he warned against the malicious temperaments of hired wet nurses, saying their wicked, indolent personalities and drinking habits will corrupt the children they feed. ${ }^{99}$

The unflattering characterization of a wet nurse constructed by Matteo Palmieri, Paolo da Certaldo, and others is portrayed in François Clouet's painting in the National Gallery of Art in Washington D.C. (fig. 1.10). The unknown woman in A Lady in Her Bath is pictured as a half-length nude. She was once thought to be linked to Diane de Poitiers, King Henry II's mistress, but according to Washington's National Gallery of Art's research, that possibility has been ruled out. The website offers the conjecture that, "It may be that she is meant to represent an ideal beauty."100 She is depicted emerging from her bath; her breasts are round, fresh, and not sagging from maternal nursing. In the middle-ground the wet nurse is holding the woman's baby at her full breast. The wet nurse is the antithesis of an ideal beauty. Her portrayal is virtually a caricature reflecting period writers' complaints about wet nurses' temperaments. Her peasant clothes and unbecoming facial features provide a startling contrast to the beautiful lady. She wears the cartoonish expression of a malcontent, or as Paolo da Certaldo asserted someone "not right in the head." Her expression is so unusual it is unsettling. A healthy pink-cheeked toddler plays in the middle-ground, as if he is proof of the successful wet nurse arrangement. Another stark contrast to the wet nurse occurs in an attractive still-life of flowers and fruits in the foreground, which symbolizes the fresh beauty and fertility of the young woman. While the Madonna lactans was meant to be an advertisement

\footnotetext{
${ }^{99}$ Palmieri, 13.

100 "François Clouet, A Lady in her Bath," The Collection, The National Gallery of Art, http://www.nga.gov/collection/gallery/gg41a/gg41a-46112.html.
} 
advocating maternal feeding, this painting sends mixed messages. Although the idealized mother and healthy toddler provide a justification for hiring a nurse, the wet nurse's characterization might dissuade viewers. Clouet's image was a rarity, however. We have so few secular portrayals of wet nurses, but people received warnings from other sources.

Advice about engaging a wet nurse's services was not only available in writing, but it was dispensed to the public through preaching. Sermons were accessible to all classes; the educated and illiterate, the noble and country folk all gathered to listen to popular Italian preachers such as San Bernardino of Siena. Franciscan San Bernardino's sermons had become enormously fashionable in fifteenth-century Tuscany. He addressed women of every level of society. They were described as "fine ladies ... in high headdresses ... pious old crones in long black cloaks ... stout peasant women with country baskets, and ... pretty girls." ${ }^{, 101}$ His modern biographer, Iris Origo, surmised his popularity with female members of the congregation might have been due to the fact that he was brought up in an all female household and knew well how to relate to this audience. ${ }^{102}$ Yet the preacher was not always easy on the female sex. He objected strongly to women not nursing their own children but granted that when they were in poor health or had an inadequate milk supply, it was allowable. He frowned upon those women who used "unlawful" excuses for hiring a balia. Those who wished to "procure [themselves] more pleasure" were intolerable. ${ }^{103}$ Although his sermons were sympathetic to the heavy burdens and duties of a wife and mother and he declared women's

\footnotetext{
${ }^{101}$ Iris Origo, The World of San Bernardino. (New York: Harcourt, Brace \& World, Inc., 1962), 43.

${ }^{102}$ Origo, World, 44. This popularity is also attributable to his spoken compassion for women's role as bearer of children, her labor pains, and the carrier of household burdens. Surely his empathy made him popular among female audiences, "Women, Women, I am on your side." And "If only God had given one part of all this to the man, at least in giving birth!" Quoted in Origo, 59 and 60.

${ }^{103}$ Ross, 186.
} 
forbearance of those burdens "suffice[d] for her to deserve eternal life," ${ }^{104}$ he was unrelenting on the subject of the wet nurse because of what may be passed on by a hired woman. His commentary demonstrates his belief that it was the wet nurse's lifestyle, rather than her milk, as believed by some medical advisors, that transmits her less attractive attributes.

Even if you are prudent and of good customs and habits, and discreet ... you often give your child to a dirty drab, and from her, perforce, the child acquires certain of the customs of the one who suckles him. If the one who cares for him has evil customs or is of base conditions, he will receive the impress of those customs ... ${ }^{105}$

Elsewhere he ranted, "You give your child to be suckled by a sow, where he picks up the habits of his nurse.... And when he comes home you cry, 'I know not whom you are like: this is no son of ours!",106 Such contemptuous classifications as "dirty drab" and "a sow" indicate that there is more at play than a caution against the hiring of a surrogate. The distinction between classes is clear in San Bernardino's sermons and were so common in fifteenth century Tuscany that the preacher's popularity was unscathed by his use of pejorative remarks, even though it is known he addressed and apparently appealed to all classes. Women would rise early to secure a spot in the Campo of Siena on the day of his sermons. Recall they were a diverse population, described with such colorful expressions as, "refined," “delicate," "old," and a "harlot." 107

As a student of San Bernardino's, Maffeo Vegio (ca.1407 - 1458) echoed his teacher's sentiments a generation later. He condemned the disinclination of mothers to nurse their own babies as "monstrous:"

\footnotetext{
${ }^{104}$ Quoted in Origo, World, 59.

${ }^{105}$ Quoted in Ross, 186.

${ }^{106}$ Quoted in Origo, World, 60.

${ }^{107}$ Origo, World , 43.
} 
This is monstrous: that those whom they have nourished, with their own blood, in the deepest recesses of the uterus without having seen them, are denied so cruelly the gift of their milk, given to them for no other purpose, once they bring them into the world and see them, at whom they are now smiling and talking friendly, whose sweet murmurs and calls for help they latch onto; this is monstrous, that the love that naturally exists in all living beings for their children, is transferred to other women for the sake of nourishment. ${ }^{108}$

These were curiously strong words from a man who was himself fed by a wet nurse.

Maffeo Vegio wrote that his mother "always nursed her own children unless she was prevented by ill-health or lack of milk, which was often the case." And this was the case with Maffeo and his brother Lorenzo, who were both entrusted to wet nurses. ${ }^{109}$ The conflicting message between Vegio's vehement words against employing a wet nurse and the fact that he had been fed by one demonstrates the ambivalence between advice dispensed and people's habits during the period. These didactic words often went unheeded. Yet there was no ambivalence in the message inherent in the image of the nursing Madonna which exactly matched what these sermons held up as moral behavior, as we have expressed previously.

Occasionally records show parents were against the practice of hiring someone else to feed their own infants. For example, Giorgio Vasari distinguished Renaissance painter Raphael $(1483-1520)$ as the only artist about whom he wrote, as the beneficiary of his mother's own milk. According to Vasari, Raphael's father insisted that his son "be suckled by his own mother and should be trained in childhood in the family ways at home rather than in the houses of peasants or common people with their less gentle, indeed,

\footnotetext{
${ }^{108}$ Maffeo Vegio, Maphei Vegii laudensis De educatione liberorum et eorum claris moribus libri sex; A Critical Text of Books I - III, ed. Maria Walburg Fanning and Anne Stanislaus Sullivan (Washington D.C.: The Catholic University Press, 1933 - 36), 22 - 23. I am grateful for the translation provided by Professor Peter van Minnen, University of Cincinnati, Department of Classics, and his student Andrew Connor. No translation of this work exists in print.

${ }^{109}$ Ross, 188.
} 
their rough manners and behaviour." ${ }^{\prime 10}$ The painter's father's insistence on maternal feeding had nothing to do with the loving bond a mother could achieve with her child and everything to do with the undesirability of a wet nurse. Bigotry and class discrimination were very much a factor. This attitude permeated sermons, moralists' texts, medical warnings, and instructions about the purity of their milk.

Let us examine holy texts next to glean what was prescribed by these accessible, respected sources. As noted above, the most unyielding position on the subject came from sermons and stories in the lives of the saints, which explicitly condemned wet nurses and exalted maternal breastfeeding. In those sources we have seen references to mothers nursing their own infants as being the ideal Christian thing to do. Yet, the Holy Bible, Christianity's fundamental text, does not give directives to do so. ${ }^{111}$ For example the Old Testament described a nursing mother: "[I] carried you in my womb and nursed you for three years ...." (2 Maccabees 7:27). In the New Testament, while Jesus was teaching a crowd, a woman called out, "Blessed is the womb that carried you and the breasts at which you nursed" (Luke 11:27). Thus, wet nursing, if not explicitly sanctioned, is not cast as a negative thing to do in the Bible. Recall, for example, how in regard to Moses, "Pharaoh's daughter said to her [the wet nurse], 'Take this baby and nurse him for me, and I will pay you.' So the woman took the baby and nursed him" (Exodus 2:9). The potential for a close, brotherly bond between two nurslings in a wet nurse's household is emphasized in this verse: "If only you were to me like a brother, who was nursed at my mother's breasts" (Song of Solomon 8:1). Despite this, medieval

\footnotetext{
${ }^{110}$ GiorgioVasari, The Lives of the Artists, trans. George Bull (New York: Penguin Books, 1965), 285.

${ }^{111}$ After surveying biblical passages searching for the words "breast," "nurse," "nursed," and "nursing" at http://www.BibleGateway.com/ I counted all references to wet nursing and maternal nursing, finding about an equal number of references to each. No bias existed for or against either method.
} 
and early modern preachers vigorously denounced the practice of employing a wet nurse in their sermons even as the Holy Bible commented on it without a trace of disapproval. Similarly, maternal nursing, when mentioned, is shown in a neutral light. For example, after the woman who called out to Jesus, blessing his mother's womb and her nursing breasts, Jesus did not underscore the woman's approbation of breastfeeding with a word of concurrence, which he might have done if he had wanted to praise the activity. Instead he directed attention away from the maternal breast-blessing, saying, "Rather, blessed are those who hear the word of God and observe it" (Luke 11:28). Christ emphasized hearing and observing the word of God, not the lauded act of maternal breastfeeding. Additionally, Christ may have been directing attention to God or to himself, the Incarnate Son of God. The Word is explained in John's Gospel this way: "In the beginning was the Word, and the Word was with God, and the Word was God" (John 1.1). Also in John's Gospel, the Incarnation is described as, "The Word became flesh and made his dwelling among us" (John 1.14). In any case, Christ's rejoinder directs the emphasis away from Mary's nursing and toward observing the word of God.

The Christian preachers and writers of religious principles during the Middle Ages and the Renaissance - who were led by the Holy Bible - embraced maternal breastfeeding, but their interest in it must have originated from other sources. In contrast, the Qur'an is not as neutral on the issue. In the Mediterranean world Islamic people were guided by the Qur'an. Muhammad was born at Mecca in $570 \mathrm{CE}$. He was orphaned at birth and would not have survived without a wet nurse. Hassan Kamal, in his Encyclopedia of Islamic Medicine, offers this revelation: 
A wet nurse called Halima swore to her husband 'By God I shall nurse that orphan.' Request granted, she took him to the desert to live . . . Being an orphan, fed by a wet nurse . . Muhammad became a good example ... Muhammadan mothers who could not nurse their children found in Muhammad's wet nurse a good example to follow ... ${ }^{112}$

The Qur'an allows that, if a woman cannot breastfeed her child, it is not a sin to hire a wet nurse (Q: 2:233). On the contrary, the wet nurse appears to be celebrated. In this passage the benevolence of Musa's wet nurse is emphasized: “. . . [H] e refused to suck any foster mother before, so she [Musa's mother] said: shall I point out to you the people of a house who will take care of him for you, and they will be benevolent to him?” (Q 28:12). Nonetheless, the practice of hiring of a wet nurse by Muslim people was not as widely embraced as by Christian people during our period of study. ${ }^{113}$ Additionally, Islam did not restrict sexual relations during lactation. Muhammad's contemporary Judhama bint Wahb wrote, "I was there when the Prophet was with a group saying, 'I was about to prohibit the ghila [sexual intercourse with a lactating woman], but I observed the Byzantines and Persians, and saw them do it, and their children were not harmed." "114 Perhaps that is one explanation why the incidence of hiring wet nurses was low among Muslim people. Certainly we cannot point to taboos in the Qur'an.

Because this study examines medieval and Renaissance Italian people's reaction to the Madonna lactans image, our interest is primarily centered upon observations about Christian customs and behaviors, but a brief examination of what the Qur'an says

\footnotetext{
${ }^{112}$ Hassan Kamal, Encyclopaedia of Islamic Medicine (Cairo, 1975), 745. Quoted in Fildes, 26.

${ }^{113}$ Fildes, 39.

${ }^{114}$ Basim F. Musallam, Sex and Society in Islam (Cambridge: Cambridge University Press, 1983), 15 - 16. This quote occurs in the hadith on contraception. Hadith is defined as "a tradition based on reports and the sayings and activities of Muhammad and his companions." Hadith are regarded as tools for understanding the Qur'an in matters of jurisprudence and Judhama bint Wahb's statement is listed among hadith, which recurred most often in jurisprudence. See Definitions of Hadith on the Web, http://www.google.com/search?hl=en\&defl=en\&q=define:hadith\&sa; Musallam, 15.
} 
provides a meaningful contrast to the Christian Bible. Neither the Qur'an nor the Bible denounces the custom of using a wet nurse, and while the Bible is neutral on the subject, the Qur'an casts the wet nurse as a benevolent soul and a good example for mothers who cannot suckle their own infants. This counter position, that is, the expression of what might be positive about using a wet nurse, is rarely articulated as such. If sermon writers had followed Scripture, rather than the written advice of ancient pagans, they would not have had grounds to condemn the hiring of wet nurses, as they did most adamantly.

\section{Why Hire a Wet Nurse?}

We have seen many pronouncements in sermons in which those who employ a wet nurse are vilified. Yet employ them they did. Why was the practice embraced? Despite so many written and spoken admonitions against it, one can uncover numerous reasons late medieval and early modern people embraced mercenary feeding. The length of time a child usually spent at the breast was between one to three years. One reason in favor of hiring a wet nurse might have been the prohibition against intercourse during lactation, which certainly must have made maternal feeding less attractive to couples. Psychology relative to the prohibition may have been a factor. The upper-class father took charge of the arrangements to locate and hire a balia. As David Hunt suggests, here psychological and social spheres interlocked. "The upper-class father buys a clear Oedipal victory, keeping the mother to himself. This victory is the more complete if the child is sent away to the nurse's house." ${ }^{\prime 15}$ Hunt's point may have some validity. Recall

\footnotetext{
115 David Hunt, Parents and Children in History: The Psychology of Family: Life in Early Modern France.
} (New York: Basic Books, Inc., 1970), 107. 
Soranus' warning about nursing appropriating physical pleasure that once belonged only to the husband.

Another motive had to do with a woman's decreased fertility during lactation. At a time when infant mortality rates were high and numbers of heirs were desired, the restoration of fertility was the goal. Additionally, there were objections to the toll breastfeeding took on the mothers' body; noted were both the change in her physique and the fact that the task was physically exhausting. For example, a noble lady justified hiring a wet nurse due to her desire to "keep her breasts small."." Simon de Vallembert, the author of the first printed work on pediatrics in French (published in 1556), explained the retention of a nurse was because mothers desired to preserve "a slender figure, pretty breasts, firm nipples, round and smooth." ${ }^{117}$ The Lady in Her Bath (fig. 1.10) illustrates the point well. The unknown woman is called an ideal. Clearly her firm, round, and smooth breasts are preserved, and her child's wet nurse is portrayed in contrast in the background. Favorinus' speech to the young couple with the newborn was prompted by the new mother's own mother, who insisted on hiring a wet nurse. She fretted her daughter was already exhausted from giving birth and wanted to save her from "the wearisome and difficult task of nursing ... $" 118$

Later medical writers acknowledged that breastfeeding was physically taxing but did so in an unfavorable light for women. Fourteenth-century medical practitioner Bernard de Gordon's contribution to the subject of breastfeeding took the guise of disparaging female behavior (not a medical position), rather than lifting up the virtues of

\footnotetext{
${ }^{116}$ Nicholas Orme, Medieval Children (New Haven: Yale University Press, 2003),58.

${ }^{117}$ Hunt, 107.

${ }^{118}$ Gelius, 353.
} 
mother's milk as Bartholomaeus Anglicus and other medical advisors of the period did. Bernard de Gordon asserted that "women nowadays are too delicate or too haughty, or they do not like the inconvenience [of breastfeeding]." ${ }^{\prime 19}$ Despite his bias his wording reveals why people chose to hire a wet nurse. His use of the phrase "too delicate" points to the perceived physical toll breastfeeding took on women. And his accusation about women being "too haughty" refers to the status issue inherent in the hiring of a wet nurse. Widespread use of wet nurses among the nobility and merchant classes was well established in Renaissance Florence and presumably elsewhere. A low incidence of mercenary feeding among working-class people in the fourteenth century gave way to a significant increase in the practice among lower classes, who may have perceived it as a symbol of gentility or status by the middle of the fifteenth century onward. ${ }^{120}$

Although all advice was heartily in favor of mothers nursing their own children, Italians hired surrogates. Christiane Klapisch-Zuber maintained that the disregard that Italian males showed for all the advice given by their "medico-moral literary heritage" was tied to the belief that children belonged to the father and to his kinship group. She held that the only valid anchors for personal identity believed to be acceptable by Italian males lay in the kinds of patrimony received in the male line. Klapisch-Zuber concluded that the mothers' qualities were not passed down to Italian male children. Therefore, a

\footnotetext{
${ }^{119}$ Quoted in Demaitre, 474

${ }^{120}$ Christiane Klapisch-Zuber, "Blood Parents and Milk Parents," in Women, Family, and Ritual in Renaissance Italy, trans. Lydia Cochrane (Chicago: University of Chicago Press, 1985), 135. Fildes, 49. Ross, 186. Klapisch-Zuber based her research on the scrutiny of numerous ricordi and ricordanze (family memoirs) in Florentine archives from 1320 to 1530, comprising 180 samples. Louis Haas took exception to this sampling of recorded memories, calling them too random and saying there is not a representative sample in her research. He asserted, "Her sample size is woefully small." Louis Haas, The Renaissance Man and His Children: Childbirth and Early Childhood in Florence (New York: St. Martin's Press, 1998), 90. Although it is clear that he is critical of her research, Haas used Klapisch-Zuber's work as a resource throughout his own research.
} 
wet nurse could stand in for the mother without the offspring losing its paternal lineage. Finally, she reasoned that this explains the remarkable absence of the mother in all that pertains to her children. ${ }^{121}$ It is generally true that child-feeding advice went unheeded by a sizable percentage of Italian males, but for Klapisch-Zuber's model to be accurate the wholesale disregard of all counsel would have to have taken place. We have Raphael's father as an exemplary exception. Furthermore, discussions about wombblood turning into milk, warnings about the mother's character traits - good and bad being transmitted through the milk ducts, and requisites about qualities in a wet nurse, especially those about wet nurses resembling natural mothers, would have to have been ignored. We have seen a good deal of ignoring of advice being exercised, true, but Klapisch-Zubers's argument asks for a blanket disregard of all advice. Indeed, most often advice about maternal feeding and choosing a wet nurse came from contemporary Italian men. Moreover, we have seen evidence of a woman's written advice (Trotula's) about the selection of a wet nurse, which arguably represents a duplication of maleauthored texts, other than for the fact that it contains no urging toward maternal feeding. ${ }^{122}$ There can be little doubt that the male dominated society and all its integrated ideals played a major role in the decision to hire a surrogate nurse, but many other factors also contributed. The reasons were as varied and individual as the unique Italians who turned away from the enticements of the natural loving bond promised to mothers and toward the conveniences promised in the contract with a balia.

In an earlier study, Christiane Klapisch-Zuber and David Herlihy offered an alternative hypothetical reason people engaged in mercenary feeding. Late fourteenth

${ }^{121}$ Klapisch Zuber, "Blood Parents," 162.

${ }^{122}$ See Trotula above, 39 and n. 92. 
and early fifteenth-century Tuscans suffered exorbitant mortality rates due to disasters such as famine and plague. The two historians asserted high infant mortality rates discouraged parents from wanting to form a loving bond with their newborn babies - the very bond demonstrably delivered by maternal nursing in images and texts. "The horrible mortalities in the early years of life discouraged parents, we believe, from forming a deep emotional attachment with their newborn babies. This reluctance abetted the practice of dispatching the babies to wet nurses." ${ }^{\text {23 }}$ This hypothesis is not supported by further data in their book, but it is reflective of a view that medieval people had a lack of feeling for their own offspring, that parents postponed allowing themselves to become attached to their children until they were certain of their children's survival.

Medieval scholar Philippe Ariès proposed this position in the 1960s. He wrote, "People could not allow themselves to become too attached to something that was regarded as a probable loss." ${ }^{, 24}$ Ariès surmised that parents braced themselves against the pain of loss by not becoming attached in the first place. His conjecture, he noted, should not be shocking. "There is nothing about this callousness which should surprise us: it was only natural in the community conditions of the time." ${ }^{125}$ His conclusions have been countered by a good many recent historians. Louis Haas took the opposing view. He began his book The Renaissance Man and his Children with a letter written about parental love by Boccaccio to his friend Petrarch in 1366. A sample from that letter reads, "Ah, how often, holding your child in my arms and listening to her prattle, the

\footnotetext{
${ }^{123}$ David Herlihy and Christiane Klapisch Zuber, Tuscans and their Families: A Study of the Florentine Castato of 1427 (New Haven: Yale University Press, 1985), 256. Originally published as Les Toscans et leurs familles. Une etude du Castato florentin de 1427(Paris: Presses de la Fondation Nationale des Sciences Politiques, 1978).

${ }^{124}$ Philippe Ariès, Centuries of Childhood, a Social History of Family Life, a translation of L'Enfant et la vie Familiale sous L’Ancien Regime, trans. Robert Baldick (New York: Vintage Books, 1962), 38.

${ }^{125}$ Ariès, 39.
} 
memory of my own lost little girl has brought to my eyes tears that I conceal from all."126 The letter reflects Boccaccio's great love for his deceased child, and Haas used the letter as a piece of evidence to discredit the historical thesis promulgated by Ariès, that is, that premodern childhood was a time of neglect and abuse. ${ }^{127}$ Nicholas Orme also argued against the notion, writing that Ariès's findings were not based on thorough research, and he lamented that Ariès's views had been influential especially among those who are not medieval historians. Orme listed a corpus of research conducted since Ariès's work was published. He said of the scholars, "They have gathered copious evidence to show ... that parents treated children like children ... and they did so with care and sympathy . . ."128 To repeat, according to Klapisch-Zuber and Herlihy, deliberate emotional distancing gained through the practice of hiring a wet nurse was evidence of neglect. Haas countered by writing, "Because of its utility and ubiquity, wetnursing, rather than appearing as some form of abuse and neglect, was similar in function to daycare today.,"129

Both positions are too extreme. Klapisch-Zuber and Herlihy paint the medieval parent as cold-hearted and interested mainly in safeguarding themselves from the pain of loss, regardless of the cost to their child. Haas's analogy is woefully imprecise and oversimplifies the practice of employing a wet nurse with all its social, economic, and historical nuances. Sending a child to day care each day while parents work is not

\footnotetext{
${ }^{126}$ Haas, 1.

${ }^{127}$ Orme,4. Orme listed Lloyd de Mause and Lawrence Stone as other exponents of this view.

${ }^{128}$ Orme, 5. The list includes, Shulamith Shahar, Childhood in the Middle Ages , trans. Chaya Galai (London, Routledge, 1990). Pierre Riché and Danièle Alexandre-Bidon, L'Enfrance au Moyen Age (Paris : Seuil : Bibliothèque nationale de France, 1994). Sally Crawford, Childhood in Anglo-Saxon England (Gloucestershire: Sutton, 1999). Barbara Hanawalt, The Ties that Bound: Peasant Families in Medieval England (New York: Oxford University Press, 1986).

${ }^{129}$ Haas, 7.
} 
remotely comparable to sending a child to a wet nurse for up to three years. Indeed there is no modern-day analogy. The issue is not black and white; in reality both positions have shades of credibility. Bernard de Gordon's admonitions about women not wanting the inconvenience of nursing one's own baby or of women being too haughty or delicate complement Klapisch-Zuber's and Herlihy's hypothesis. On the other hand, Haas does take a legitimate position when he asks, "If wetnursing was supposedly such a wretched experience for all involved, why was it so widespread; and why did even the harshest critics of the practice advise it in certain circumstances?"130 Why so many paradoxical perspectives?

Recall, for instance, Maffeo Vegio, who remembered his nurse with affection, crediting her with some of his best qualities, but later he wrote that a mother who puts her child out to nurse was monstrous. ${ }^{131}$ Although present-day sensibilities cause us to wince at the idea that parents would choose to send a child away to nurse at the breast of a hired woman for one to three years, it is inadequate to apply present-day sensibilities to historical scenarios. Here is the conundrum that may never be fully satisfied. The practice was widespread; historians criticized it as wretched; almost all advisors spiritual, medical, moral, and didactic - denounced it, yet the practice prevailed.

We have examined the many reasons why medieval and early modern people may have indulged in hiring a wet nurse. A desire to resume sexual relations, the return of fertility, vanity, the wife's desire to be free of the constraints of breastfeeding, the husband's belief that only his essence mattered, his desire for control over his wife's

\footnotetext{
${ }^{130}$ Haas, 7.

131 See above, p. 17 and 23.
} 
body in the matter of assuring progeny, and the aspiration to show evidence of status apparently drove the decision to hire a wet nurse. Sex, fertility, vanity, comfort, convenience, control, and status have driven human behavior for centuries and continue to do so.

Yet the image of the Virgin feeding her own Son was prized in late medieval and Renaissance Italy. The Church continued to commission the lactans image, it was also commissioned by private individuals, it adorned street corner shrines, and people even carried plaquettes of the image in their pockets. We shall seek to understand why presently. But first we return to a fuller grasp of all the era's aspects of feeding infants. An understanding of the private and institutional wet nursing profession will be productive for our study. The business of wet nursing was complex emotionally, philosophically, and economically. In fact it was quite a viable industry. From the perspective of the wet nurse and her husband who brokered her services, the post was economically attractive. For service-oriented positions such as this, the pay was the highest a woman could earn.

\section{The Wet Nursing Profession}

Being a wet nurse was indeed a rather well-paid occupation. Compared to other positions like chambermaid, wet nurses were compensated relatively well. In an ordinance issued by the King of France dated 30 January 1350 the wages were listed. According to available French sources, a wet nurse taken into a child's home would be paid fifty sols a year, plus food and lodging. Wet nurses who brought the baby to live in her own home would earn one hundred sols a year. Fildes surmised the extra "for 
outnursing presumably was to cover food and other necessities while [the wet nurse] was nursing." 132 For comparison's sake, a chambermaid would be given about thirty sols a year. ${ }^{133}$ In every study about wet nurses' wages conducted by Fildes, the salary paid to a wet nurse was much higher than that paid for any other occupation available to a woman. ${ }^{134}$ Unlike France, Italy's nurse in casa, that is a wet nurse who lived with the family, was paid premium wages. Between 1400 and 1480 the going wage was eighteen to twenty fiorini a year, which was higher than any other category of hired domestics. During the same period, a nurse who took the child to her home in the country was paid between nine to fifteen fiorini depending upon how far away her home was from Florence. ${ }^{135}$ For Florentines, choosing to hire a wet nurse meant separation from the child in the majority of instances. Klapisch-Zuber traced the whereabouts of nurses' residences and found no reluctance on the part of Florentines to send their infants far from home. ${ }^{136}$ Since documents show such a geographical separation, how was the ideal wet nurse located? It was the husband's role to find the proper surrogate. If he held land in the countryside he could keep track of promising potential pregnant or nursing mothers in villages and on farms. Additionally, in Italy at least, many ricordanze reveal an intermediary who would help in the process. ${ }^{137}$ In France, a woman called a

\footnotetext{
${ }^{132}$ Fildes, 36.

${ }^{133}$ Fildes, 36.

${ }^{134}$ Fildes, 38.

${ }^{135}$ Klapisch-Zuber, "Blood Parents," 136. See also Levin, "Studies in the Images of Mercy," Appendix B, 960-961 and n. 16, 965.

${ }^{136}$ Klapisch-Zuber "Blood Parents," 135-137. In the documentation of over 400 nurses between 1300 1530 , one nurse was hired in casa versus more than four who took the baby to their own houses.

${ }^{137}$ Klapisch-Zuber, "Blood Parents," 139.
} 
reccommandaresse would receive a finder's fee for locating a suitable wet nurse for wealthy couples. ${ }^{138}$

The suitability of a wet nurse was an important issue as well. The exact specifications can be found in numerous writings, medical, philosophical and moral. Aldebrandin de Sienne (d. 1287) wrote Régime du corps in the thirteenth century. It is a dietetic text, which examines nutritional aspects of preserving health. Aldebrandin drew heavily on the medical writings of Avicenna's Canon of Medicine. In his writings Aldebrandin recommends that the wet nurse be in the prime of her life, have an appearance something like the mother, have big, hard breasts, be in good health and pay special attention to her diet. He also mentions the abstention from sexual relations. ${ }^{139}$ Alberti called for "one who is happy, clean, free of any heat or turbulence of blood or spirit; let her live moderately, nor be intemperate or improper in any way."140 Medical physicians from the first and second centuries CE wrote about the things to look for in a wet nurse, and their advice resonated through the centuries. Qualities particular to a potential wet nurse's health, moral behavior and physical appearance, were variously repeated by other essayists we have encountered before. Francesco da Barbarino, Paolo da Certaldo, S. Bernardino da Siena, and Matteo Palmieri are among them. ${ }^{141}$ These were repeated by the Italian doctors of the sixteenth century. ${ }^{142}$ In all of their essays Soranus' advice is echoed. Soranus recommended:

\footnotetext{
${ }^{138}$ Fildes, 36.

${ }^{139}$ Daniele Alexandre-Bidon and Didier Lett, Children of the Middle Ages; Fifth - Fifteenth Centuries, trans. Jody Gladding (Notre Dame, IN: University of Notre Dame Press, 1999), 68.

${ }^{140}$ Alberti, 54.

${ }^{141}$ For an account of these writers' counsel on the subject of what to look for in a wet nurse see Levin, "Studies in the Imagery of Mercy," Appendix B, 958 - 59.

${ }^{142}$ Ross, 190.
} 
One should choose a wet nurse not younger than twenty nor older than forty years, who has already given birth twice or thrice, who is healthy, of good habits, of large frame, and of good color. Her breasts should be of medium size, lax, soft and unwrinkled, the nipples neither big nor too small and neither too compact nor too porous and discharging milk overabundantly. She should be self-controlled, sympathetic and not illtempered, a Greek, and tidy. . . She should be self-controlled so as to abstain from coitus, drinking, lewdness, and any other such pleasure. ${ }^{143}$

Soranus explained each qualification. He mentioned the fear of suffocation several times. Large breasts could fall on the baby and suffocate her; nipples that were too porous brought on the danger of suffocation because "the milk is brought to the mouth overabundantly." In regard to drinking alcohol, the nurse could be "seized by sleep [and] ... fall down upon [the newborn] in a dangerous way."144

Overlaying - the death of an infant by suffocation - in the nurse's (or mother's) bed was a universal problem and was usually ruled accidental because it was difficult to prove otherwise. ${ }^{145}$ The majority of couples seeking absolution for such an occurrence were not the parents of the baby but the wet nurse and husband. ${ }^{146}$ In medieval and early modern Florence, a protective cradle called arruccio, designed to protect the baby from the nurse's sleepy, crushing body, became prevalent; the use of it was made Church law, and failure to use it was punishable by excommunication (fig.1.11). The devices were used in Florence for several hundred years, and one suspects its employment elsewhere as well. $^{147}$

\footnotetext{
${ }^{143}$ Soranus, 90 .

${ }^{144}$ Soranus, 93.

${ }^{145}$ Fildes, 47; Richard Trexler, "Infanticide in Florence: New Sources and First Results," The History of Childhood Quarterly, 1 (1973): 103 - 9; McLaughlin, 117, 120 - 1, 156 - 7, n. 102.

146 Trexler, "Infanticide," $106-7$.

${ }^{147}$ Fildes, 47; Klapisch-Zuber, "Blood Parents," 149.
} 
Ironically life and death crossed paths in the selection of a nurse. The most desirable nurse was one who had recently buried an infant of her own. She would have been lactating, her milk "fresh," and the problem of feeding her own baby would not have been an issue. The letters written between the busy entrepreneur Francesco di Marco Datini (1335 -1410) and his wife Margherita reveal examples of these criteria. While away from his home in Prato, Francesco charged Margherita to find balie for a number of his Florentine associates. ${ }^{148}$ Margherita often complained to her husband about the hardships she encountered in finding suitable balie, and her words divulge a callous disregard for the potential wet nurse. Known through their copious correspondence, the difficulties Margherita faced in this task also underscored her requisites. "They seem to have vanished from the world, for none has come into my hands. And some I had at hand whose babes were at the point of death, but now they say they are well again.” The complaint that a potential nurse's baby did not die reveals the extent to which the balia was viewed as a product, not a person. One girl was located but dismissed because her mistress complained that "the longer she stays, the more evil she becomes - and besides she has only one eye." The suspicion that a wet nurse would be partial to her own nursing child was evident in Margherita's statement, "Never shall I believe that when they have a one-year-old child of their own, they give not some milk to it." ${ }^{149}$ Further evidence of the callous attitude is reflected in Margherita's hope in finding a newly grieving mother. "I have found one in Piazza della Pieve, whose milk is two months old; and she has vowed that if her babe, who is on the point of death, dies tonight, she will

\footnotetext{
${ }^{148}$ Iris Origo, The Merchant of Prato, Francesco di Marco Datini, (New York: Alfred A. Knopf, Inc., 1957), 215 - 216. Origo surmised that this was a side-line undertaken for profit by Fransesco.

${ }^{149}$ Origo, Merchant, 216.
} 
come as soon as it is buried." ${ }^{, 150}$ Breast milk was a commodity, the balia, the source and distributor. Margherita's unsympathetic words highlight the cold nature of the business. The search for sustenance for life provoked an eye for impending death.

\section{Institutional Wet Nurses}

We have examined what is known about privately employed wet nurses, but increasingly institutions turned to their service to feed their growing numbers of orphaned babies. Late medieval and Renaissance Italian institutions were swollen with children who had been orphaned or dropped off by parents unable to feed and care for their babies. In an era besieged by famine, common infectious diseases, poverty, and the plague, the numbers of abandoned children increased dramatically. Methods for abandoning children differed from city to city and at each institution. For instance, a foundling wheel, or ruota, facilitated a safe drop-off. The baby would be left on the outer portion of the wheel and then rotated to the interior, out of harm's way. Another receptacle was a stone basin or pila, the kind used for holy water. In Florence the Spedale degli Innocenti added an iron-reinforced window (finestra ferrata) into which the basin was wedged; the grill necessarily controlled the size of the babies. From the early cinquecento at the Innocenti, a tradition was instituted whereby the new foundling, once inside, was placed in a crèche between Mary and Joseph, a pair sculpted by Marco della Robbia in 1505 . The living "baby Jesus" completed the Nativity scene (fig. 1.12). ${ }^{151}$ The ritual of engaging with these sculpted images in this way demonstrates how people interacted with artwork during the period. Mary and Joseph were surrogate

\footnotetext{
${ }^{150}$ Origo, Merchant, 216.

${ }^{151}$ Caterina Leoni, Maria Cristina Montanari, and Paola Senesi, eds. The Renaissance of Children, trans. Mary Jane Poole (Florence: Institute of the Innocents, 2007), 12 - 13.
} 
parents. The tradition reveals a pervasive mentality during the period about Marian devotion and the role artwork played.

The numbers of abandoned infants at the Innocenti grew considerably over the course of a few decades. In 1468 there were four hundred foundlings being breastfed outside the institution and three hundred in the Innocenti. By the middle of the next century there were two-thousand "mouths to feed" in all under the aegis of the Innocenti. ${ }^{152}$ The increase in institutional demand for wet nurses' services out-weighed the availability. Directors of children's hospices encountered tremendous difficulties trying to keep up with the demand for wet nurses. William Levin researched another Florentine orphanage - the Confraternity of the Misericordia. Impoverished young women (at the behest of their fathers or husbands) sought employment as wet nurses. Levin detailed some astonishing practices undertaken by wet nurses to gain employment at this and other institutions. ${ }^{153}$ He revealed there were unmarried teenage women who deliberately became pregnant in order to be hired as institutional wet nurses. He explained, "... [P] resumably they abandoned their own children to the care of a foundling home or, worse, saw to their deaths." Additionally, some women secretly abandoned their own babies to the care of a foundling home and, after being hired by that institution, endeavored or hoped to be assigned as the nurse of their own baby for payment. There are reports of women whose milk had deteriorated in quality, and rather than notifying hospital authorities, they supplemented with animal milk or simply began

\footnotetext{
${ }^{152}$ Leoni, et. al., 14.

153 See William R. Levin, "Advertising Charity in the Trecento: The Public Decorations of the Misericordia in Florence," Studies in Iconography, 17 (1996), 245 - 46.
} 
the weaning process prematurely, to the detriment of the infants' health. ${ }^{154}$ Some wet nurses waited as long as possible before bringing their charges back to the hospitals that employed them so as not to lose wages. These practices contributed to the high infant mortality rates in foundling hospitals. The Misericordia dealt with the business of locating, hiring, and supervising wet nurses for its own institutional needs and aided the search for wet nurses at other major hospices for children, such as Ospedale di San Gallo, Santa Maria della Scala, and the Innocenti. ${ }^{155}$

Studies regarding these hospitals throughout this period (and beyond) reveal the strain on the supply of wet nurses. Richard Trexler reported that in 1466 the Innocenti had need of so many wet nurses on the payroll that the "countryside was increasingly turned into a milk farm for the Innocenti."156 The majority of foundlings were not fed in the institutions proper. For instance, eighty percent of the youngsters in the San Gimignano foundation had to be sent out to nurse at the homes of the balie, making supervision of the quality of care next to impossible. Abandoned infants' weight and health declined as administrators scrambled to search for wet nurses in their charges' first critical days at an institution. ${ }^{157}$ Hospitals hired in-house balie for such vital, immediate care. Records tell us the first woman hired as the Innocenti's internal wet nurse was a certain Lady Chiara. She arrived in 1444 with her own child of only a few months still at her breast. The documents tell the sad story of Lady Chiara's separation from her baby

\footnotetext{
${ }^{154}$ Levin, "Advertising Charity," 245 - 46. Levin reported that these situations occurred at the Ospedale della Scala in San Gimignano and deduced that there is no reason to believe these and other equally reprehensible situations by wet nurses did not occur elsewhere.

${ }^{155}$ Levin, "Advertising Charity," 247.

${ }^{156}$ Trexler,"The Foundlings of Florence, 1395 - 1455," History of Childhood Quarterly, 1 (1973): 284.

${ }^{157}$ Levin, "Advertising Charity," 246.
} 
daughter, who was then entrusted to an outside wet nurse at her own expense. ${ }^{158}$ In practice, nursing one's own infant forms a bond which grows stronger with each passing day. We have seen written textual evidence of the benefits of this loving bond. Hence, Lady Chiara's and other mothers' separation anxiety would have been dreadful. As we shall see presently, Levin developed a convincing argument for the Madonna lactans image as a source of comfort for parents who necessarily dropped their children off to be cared for at an institution. He argued that the Misericordia and other hospitals were adorned with art that reflected the comfort and charity available inside.

\section{Madonna Lactans Adorning Charitable Institutions}

A sculptural lunette relief of the Madonna and Child adorns the entrance to the oratory of the Misericordia. Levin wrote a comprehensive study about this mid-trecento half-length relief by Alberto Arnoldi (fig. 1.1). ${ }^{159}$ In the relief the Virgin is smiling and is tenderly interacting with the Christ Child. The smiling Christ Child pulls at his mother's neckline, indicating he wants to nurse. Levin established that this Madonna lactans image (as well as several other images that adorned the building) was indicative of merciful behavior, which was the mission of the Misericordia. He wrote, "Hence, the sculpture refers to the general nature and purpose of the buildings' occupants.... It advertised that one of its [the Misericordia's] good works was the care of defenseless children." ${ }^{160}$ Furthermore, Levin demonstrated that the relief provided comfort for indigent parents who were forced to abandon their children, symbolizing the care and

\footnotetext{
${ }^{158}$ Archives of the Hospital of the Innocents of Florence (Balie a fanciugli A) $(1444-1451)$, c. 3, n. 5. I am grateful to Innocenti archivist Lucia Ricciardi for her assistance.

${ }^{159}$ Levin, "Advertising Charity" $242-47$. See also William R. Levin, The Allegory of Mercy at the Misericordia in Florence: Historiography, Context, Iconography, and the Documentation of Confraternal Charity in the Trecento (Lanham, MD: University Press of America, 2004), 57 - 58.

${ }^{160}$ Levin, "Advertising Charity," $243-44$.
} 
mercy their child would receive there, no less than that supplied by the Virgin for her Son. "The serenity and happiness emanating from Mary and the Christ Child as they are about to engage in the act of nursing can be understood as an effort to put a burdensome, uncertain, at times even desperate situation in a positive light." ${ }^{\prime 161}$ The Spedale e Museo degli Innocenti is home to a not entirely dissimilar nursing Madonna fresco. Cenni di Francesco di Ser Cenni's Madonna with Child is a half-length view of the Virgin nursing her Son, painted close to the picture plane (fig. 1.2). ${ }^{162}$ Mary's and the Christ Child's gazes are direct and inviting. Both figures stare at the spectator, projecting a warm welcome. For destitute parents, forced to turn to institutional help for the basic needs of their children, the nursing Madonna motif was reassuring.

Some of those parents were wet nurses and husbands of wet nurses who apparently felt they had no other recourse but to abandon their own children to make room for paying clients at the breast. Wet nurses were hired from a pool of women found in the lowest echelon of society - the urban poor or the rural peasantry, the very echelon whose members found themselves in uncertain and desperate situations themselves and in need of institutional services. In addition to the parents, a secondary audience for the reassuring image may have been the wet nurse. There is no way to know for certain, but as a parent letting go of her baby, the wet nurse may have taken some comfort in such an image as well. I do not intend to promote the wet nurse as a primary audience or interpretative community for the institutional Madonna lactans, however it

\footnotetext{
${ }^{161}$ Levin, "Advertising Charity,” 246.

162 According to the Innocenti catalogue, the Cenni painting originally hung in the Hospital of Santa Maria Nuova, a short distance from the Innocenti. It is a removed fresco therefore, it is unknown where it was originally located within the hospital. Both Mary and the Christ Child look directly at the viewer, the significance of which will be addressed in chapters three and four, where a more recondite meaning of the image will be considered.
} 
must be acknowledged that certainly employees of the institutions saw the images often, and may also have responded to their comforting message.

It is reasonable to assert that there were great numbers of wet nurses coming and going through the doors of institutions. Wet nurses were employed by these institutions regularly, and many cared for their charges at the hospital, as in Lady Chiara's case. Additionally, many of the children were placed in wet nurses' homes, and the nurses were required to appear at the hospital once every three months with their charges. Once the hospital was assured of a child's good health, the nurse was paid. ${ }^{163}$ Levin speculated that the nursing Madonna relief above the Misericordia served to console parents, and his assertion was defended thoroughly. It is possible that the consoling purpose Levin demonstrated for the Arnoldi relief served many wet nurses in the same way. Moreover, not only did the image comfort parents and advertise the mission of the orphanage, but it may have served its employees in another manner. Megan Holmes proposed that given the power ascribed to images of the period, it could have had totemic value, "to induce a generous flow of good milk," for the wet nurse. ${ }^{164}$ Furthermore, the image, so prominently located at the institution, may have been intentionally offered as an example to the working nurse. As summarized earlier, the Virgin's notable virtues were prescribed when hiring wet nurses for assuring that good traits would be passed down from nurse to baby. Like the Virgin Mary, a woman who abstained from sexual intercourse, was pure, humble, and sinless was highly sought after for the job. The institution's most valued employees might have seen an exemplum in Mary nursing Jesus. The foundlings' good care depended almost entirely upon the care provided by the

\footnotetext{
${ }^{163}$ Levin, "Advertising Charity," 245.

164 Holmes, 190.
} 
wet nurse. If the nursing Madonna image was understood "as an effort to put a burdensome, uncertain, at times even desperate situation in a positive light," as Levin suggested for parents, then the same purpose for the artwork might apply to the wet nurse. Theirs was certainly a burdensome, uncertain, and desperate situation as well.

We have speculated about wet nurses as despicable women who saw to their own child's death in order to qualify themselves for the position. We have seen cases of overlaying, and although difficult to prove, records indicate suspicion that suffocation of the wet nurses' charges was not always accidental. ${ }^{165}$ These facts vilify the wet nurse, and a text from the period adds credence to the wet nurses' denigration. Giovanni Morelli tells of his father's misery under the care of a wet nurse. Morelli's father recalled his balia as "the most awful bestial woman that ever was." She beat him mercilessly, and the thought of her enraged him many years afterwards. ${ }^{166}$ But that was obviously not the situation in all cases. There are records of the sadness experienced at a child's departure from her balia that project the notion of engagement and compassion instead. The time came when the wet nurse and foster father of Francesco Datini's illegitimate child, Ginevra, returned her to her father's home. The foster father wrote a touching letter to Francesco saying how much he and his wife had come to love her and asked for her to be treated kindly. He wrote, "For she is fearful, and we love her dearly, and therefore we beseech you, be gentle with her."167 Some wet nurses and husbands decided to adopt their orphaned charges from the Innocenti. Francesco di Medillo di Giorgio took an

\footnotetext{
${ }^{165}$ Philip Gavitt, Charity and Children in Renaissance Florence: The Ospedale degli Innocenti, 1410 1536 (Ann Arbor: University of Michigan Press, 1990), 235. Fildes, 47 - 48.

${ }^{166}$ Ross, 195, Haas, 115, Shulamith Shahar, The Fourth Estate: A History of Women in the Middle Ages, trans. Chaya Galai, (London: Methuen \& Co., Ltd., 1983),185. Shahar stated, "This is an extreme, though not necessarily a unique case."

${ }^{167}$ Origo, Merchant of Prato, 198.
} 
interest in the child his wife had nursed. Not only did he adopt her but he bequeathed some land, crops, and his house to her. In another instance the wet nurse appeared to be so enamored of her charge that she asked for more time with the child and volunteered to nurse her without payment. Klapisch-Zuber reported: "The most human touches in the ricordanze concern them [wet nurses] rather than the natural parents. We perceive this when we listen to one nurse, who refused further payment to prolong the pleasure of breast-feeding and enjoying the child she had raised ..."168 Furthermore, the ricordanze recorded the wet nurse's pleasure and desire to retain her charge for a while: "She said she wanted to suckle Maria until March for her pleasure, without other salary and with only her salary [as a servant]." 169 The wet nurse wished to extend the time with baby Maria without additional remuneration. She viewed the additional time nursing Maria as a pleasure not a job, just as the Virgin reveled in the task, as exemplified by the contented smile in the Arnoldi relief. Klapisch-Zuber reported about one wet nurse's pleasure but, indeed precious little has been recorded about what the peasant wet nurse actually thought. A written indication of what may have been in the hearts and minds of the balie themselves is preserved in the form of carnival songs. Not surprisingly, the balie presented themselves in a most positive and industrious light:

We shall take good care of him, and he will be so well fed, that we'll soon have him standing straight like a proud knight. If the baby falls sick

\footnotetext{
${ }^{168}$ Klapisch-Zuber, "Blood Parents," 162. The epigraph to which the author referred introduces her chapter, "Blood Parents and Milk Parents: Wet Nursing in Florence, 1300 - 1530," 132.

${ }^{169}$ Ricordi d'Andrea Minerbetti, Biblioteca Laurenziana, Acquisti, 229, fol. 45. Quoted in Klapisch-Zuber, "Blood Parents,"162, n. 99.
} 
or is a bit run down, we'll take such good care of him that he will soon recover: but we must help him out in changing him frequently; when he's wet, we must dry him and wash him with a little wine. ${ }^{170}$

The conscientious wet nurse of this and other songs belies the reports of neglect we have observed, although because the song is in the first person, one would not expect it to reflect negativity. It reflects the ideal. So too, does the image of a healthy, loving Madonna, and a fat, contented baby Jesus nursing hungrily at his mother's ample breast, as we see in Ambrogio da Fossano’s Madonna del Latte of ca. 1485 (fig.1.14). The painting's small dimensions (21" $\mathrm{x} 17.5$ ") tell us it was likely used as a devotional piece for private prayer. ${ }^{171}$

Although the image may have served as an exemplum for wet nurses, the ideal and the truth were sometimes far apart. There is evidence of wet nurses' kind treatment and poor treatment; certainly both occurred. And yet, the practice would not have been so ubiquitous and would not have prevailed for hundreds of years if the abuse was the rule rather than the exception. We cannot be certain of every emotion felt by every wet nurse in medieval and early modern Italy, but we can be certain that the callous attitude reflected in Margherita Datini's words to her husband in no way reflected the grief felt by

\footnotetext{
${ }^{170}$ Ross, $192-93$.

${ }^{171}$ See chap. 2 for more about devotees' responses to devotional paintings.
} 
the mother who recently buried a child. It does, however, reflect the unsympathetic class-conscious attitude in the arrangements of hiring a wet nurse.

The death of her own baby was not the only way balie were rendered eligible to nurse charges. As was the case with the Innocenti's first in-house wet nurse, Lady Chiara, the nurse sometimes had to put her own unweaned baby out to nurse. This situation is also described in a Florentine balio's journal. Piero di Francesco and his wife's arrangement meant a percentage of the nurse's wage had to be spent on a wet nurse for their own child, reducing the monetary advantage considerably. ${ }^{172}$ Another solution was to anonymously abandon one's own child to an institution, or worse, to wean a child prematurely, to the detriment of her health or life. One can only guess at the emotions of the grieving-mother-cum-balia.

We have conflicting accounts of the wet nurses' mind set. We have the account of a wet nurse who found breastfeeding her charge, Maria, so pleasurable that she volunteered to prolong it at no cost. Conversely we have accounts of wet nurses who abused their charges. We know wet nurses came from the countryside, and Margherita Datini found them in the cities. They may have looked at the Madonna lactans image as totemic, to induce milk, to retain their precious money-generating commodity, as Holmes suggested. They may have found reassurance in the image of a nursing mother who was portrayed as taking obvious pleasure in their kindred task as in Arnoldi's depiction. Wet nurses were not members of a cohesive community, and therefore it is difficult to apply one hypothesis as to how such an image may have been received by the women in the wet nursing profession. Moreover we have seen that the image also served to advertise

${ }^{172}$ Klapisch-Zuber, "Blood Parents," 138 and 163. 
the mission of orphanages and to provide comfort for their clientele. All of these suggestions pertain to this chapter's effort to apply the most basic reading to the image as a simple representation of Mary feeding the Christ Child. As we shall discover in subsequent chapters, the image's enhanced potency was born of its many symbolic readings. 


\section{CHAPTER II}

\section{ITALIAN DEVOTION TO THE NURSING MADONNA}

Throughout its history Italy has been infatuated with the Virgin Mary. Devotion to her was manifest in countless practices, but an image of her was almost always a key ingredient in prayer. This chapter investigates how the Madonna lactans became an object of devotion for late medieval and Renaissance Italian people. There are records, accounts, and legends that reveal how people revered Mary; some specifically refer to nursing Madonna images, others divulge how devotees interacted with other Marian types. Information concerning devotional practices with these general types will be related to the nursing icons' functions. Furthermore, we shall analyze period Marian prayers - both those that were specific to Mary's breastfeeding or her milk - and more general ones. The prayers reveal that Italians sought intercessory help and intimacy with God through his mother.

The artwork and legends that convey Italian Marian devotion through the centuries are inspirational, charming, humorous, and at times literally incredible. Nevertheless these chronicles and their accompanying images are records of how Italians worshiped, and they deepen our understanding of historical popular religion. Images and the written word have much to disclose about two distinct categories of Marian devotion. We find that devotion was enormously public as well as deeply private. People revered 
Mary in communal rituals in city piazzas, processions, and in churches where her image adorned altarpieces. Public devotion could be theatrical and sometimes had ulterior motives, when being seen was a goal among the participants. Conversely, devotion was also very personal. Italian people of the era knelt before shrines dedicated to the Virgin in the privacy of their own bedchambers or in small chapels. Additionally, Italy is home to countless street-corner Marian shrines where people stopped to pray. But the most private form of devotion to Mary might have been performed as an individual held a small bronze plaquette relief of the Madonna and Child in his or her pocket, rubbing the surface while whispering prayers. The latter practice is part of a larger examination of people's use of their five senses in prayer, which will be discussed in greater detail in the next chapter. We will investigate how Marian images adorned houses of worship as titular symbols and as didactic tools, were seen as talismans imbued with power, and provided an exemplum for righteous living. We shall examine each type of devotional activity to understand better Italian people's relationship with the Virgin Mary, which will do much to reveal how people related to the nursing Madonna, labeled the most prevalent of the Madonna-types in the early part of our period of study. ${ }^{173}$

The Virgin has been given credit for everything from success in battles to countless miracles. Her popularity crossed every demographic. Aristocratic and working-class lay men and women, political officials, clerical persons of every rank, and peasants were drawn to her. Investigating the development of the cult of the Virgin will help explain Mary's roles as a conduit to the divine, intercessor, miracle worker, and private nurturing mother, and will be a bridge to understanding devotion to the Madonna lactans in all its guises. In sum, this chapter's consideration of the variety of Marian

${ }^{173}$ Shorr, 58 . 
images and the devotional practices they generated will enlighten subsequent comments regarding the Madonna lactans image and its function.

\section{Origins and Expansion of Medieval and Renaissance Marian Devotion}

\section{St. Bernard and Mary’s Milk}

The cult of the Virgin was one of the most dynamic and widespread developments of medieval Europe, in part due to monastic zeal for her. One of the most influential monks from the period was an ardent Marian devotee, Bernard of Clairvaux (1090 1153) who was born of a noble family and became a French Cistercian committed to monastic reform. He served the church on political missions all over Europe and was versed in the culture of chivalry and the secular poetry of love, which incorporated tales about the Virgin. His writings include more than eighty sermons on the Song of Songs in which he applied metaphors about love and the bride to the Virgin. Quoting the Song of Songs 6.10, Bernard proclaimed Mary was "as the morning, fair as the moon, clear as the sun." 174 Once, at the end of a sermon about the Assumption he gushed, "There is nothing that delights me more than to speak on the glory of the Virgin Mary." ${ }^{175}$ He preached about her role as Mother of Christ, advocate, and intermediary:

\section{Our Lady,}

Our mediatrix, Our advocate,

To your Son, reconcile us,

To your Son commend us,

\footnotetext{
${ }^{174}$ Marina Warner, Alone of All Her Sex, The Myth and Cult of the Virgin Mary (New York: Vintage Books, 1976), 130. Miri Rubin, Mother of God, 151.

${ }^{175}$ St. Bernard, in Assumptione Beatae Mariae Virginis, quoted in Jacques-Paul.Migne and J. B. Pearson, Index alphabeticus omnium doctorum, patrum, scriptorumque ecclesiasticorum quorum opera scriptaque vel minima in Patrologia Latina reperiuntur (Ridgewood, NJ: Gregg Press, 1965) 183, col. 1004 - 5, and in Warner, 130.
} 
To your Son present us, Obtain,

O blessed Lady,

By the grace found in you,

By the privilege deserved by you,

By the mercy born of you,

That he who, by your mediation,

Deigned to share our infirmity,

And our misery,

May, by your intercession,

Let us also share his glory

And his blessedness,

He, Jesus Christ,

Your Son,

Our Lord,

Blessed above all,

For ever and ever. ${ }^{176}$

St. Bernard's preaching made the Virgin approachable and her power as an advocate and intermediary attractive. In fact, Mary as intercessor was perhaps her most treasured role. He was her spokesman and champion, and his followers became her strongest admirers.

So personal was their relationship that St. Bernard is said to have had received drops of her milk during a vision. ${ }^{177}$ The legend was portrayed in manuscripts and in

\footnotetext{
${ }^{176}$ For translation and explication of Bernard's prayer see Jean Leclercq, Women and Saint Bernard of Clairvaux, trans, Marie-Bernard Saïd (Kalamazoo: Cistercian Publications, 1989), 92 - 109.

${ }^{177}$ Brian Patrick McGuire, "Bernard and Mary's Milk: A Northern Contribution," in The Difficult Saint: Bernard of Clairvaux and His Tradition (Kalamazoo: Cistercian Publications, 1991), 192 - 202. McGuire discussed several versions of the legend that vary the Virgin's motive for offering her milk to Bernard. One suggested her milk was the elixir which gave him his legendary gift for preaching; another proposed the milk was to quench his thirst, a third allowed the milk served as a healing balm. Another version of the legend held that Bernard prayed before a statue asking for proof that she was "the mother." The Virgin appeared and let three drops of milk fall to his lips. See also Warner $197-98$.
} 
paintings for centuries across Europe. (fig. 2.1). In another poem the saint praised the Virgin's breasts and milk as the means to her power. This verse demonstrates St.

Bernard's belief that the Virgin's powerful breast milk blots away the stain of sin:
Mother Mary's Breasts
Shining like a torch
Providing her Child suck
With ardor they sparkle
The stains are blotted out
With her sweet fragrance. ${ }^{178}$

The idea that Mary's milk held power was likely disseminated by St. Bernard's writings, editions of which were dispersed throughout medieval Europe. ${ }^{179}$ Additionally, the earliest collection of miracles of the Virgin compiled by the Dominicans and Cistercians (called "medieval man's" most popular reading material) included stories of the Virgin curing afflicted worshipers with drops of her milk. ${ }^{180}$ In Gautier de Coincy's telling the milk worked as a balm for a dying monk whose mouth was covered with putrid ulcers.

His fellow monks had given him up for dead, when the dying man reminded the Virgin of his faithful recitation of a passage in Luke about her: "Blessed is the womb that bore thee and the paps which thou hast sucked" (Luke 11.27). Then the Virgin appeared at his bedside and drew forth her breast "and placed it in his mouth, ... and sprinkled him with

\footnotetext{
${ }^{178}$ Saint Bernard, De uberius B. Mariae Virginis, quoted in Yrjo Hirn, The Sacred Shrine: A Study of the Poetry and Art of the Catholic Church ( London: Macmillan \& Co., 1912), 534.

${ }^{179}$ Vanessa Elena Gabrovsky, "Chaste Sexuality in Saint Bernard's Vision and the Multiplicity of Mary's Breast," (MA thesis, University of California, Los Angeles, 2004), 13.

${ }^{180}$ Warner, 198.
} 
her sweet milk." ${ }^{\prime 181}$ In a later version of the story the curative power of Mary's milk included the monk's repentance for his sins; thus body and soul were healed. ${ }^{182}$

Pilgrims seeking their own miracles went in search of Mary's potent milk. The legend of the "Milk Grotto" accounts for the origin of devotion to the precious liquid. Mary stopped to feed Christ during a rest on their flight to Egypt, where she spilled a few drops of milk on the surrounding stone, and it turned white. The grotto - in present-day southern Israel - had been a destination for pilgrims since the fourth century and was recognized in a proclamation by Pope Gregory XI in $1375 .{ }^{183}$ The burgeoning cult of the Virgin's milk flourished all over Europe. In Spain King Alfonso VI of Leon-Castille (1065 - 1109) opened a cache of ancient relics after his reconquest of Oviedo in 1075. Among other prized relics, such as bread from the marriage feast at Cana, and wood from the true cross, there was purportedly Mary's garment worn while nursing the Christ Child. Drops of her milk were preserved on it. ${ }^{184}$ In Paris, pilgrims could see a relic of Mary's milk at the Sainte-Chapelle. The relic was allegedly purchased by Louis IX from his cousin Baldwin II, Emperor of Byzantium, and a vial of the milk was housed in a silver urn there. ${ }^{185}$ Also, Fulbert of Chartres (c. 952 - 1028/9) was an ardent Marian devotee. Chartres tradition holds that Fulbert was cured by Mary's milk: "The blessed Virgin visited him when he was ill, and bathed his tongue ... with an infusion of her own

\footnotetext{
${ }^{181}$ Gautier de Coincy, Miracles de la Nostre Dame, 1223, quoted in Warner, 199.

${ }^{182}$ Evelyn Faye Wilson, ed. The Stella Maris of John of Garland, 92, quoted in Warner, 199.

${ }^{183}$ Milk Grotto, See the Holy Land, http://www.seetheholyland.net/milk-grotto/. The site is said to be sacred to Christians and Muslims alike, especially women who are trying to increase their milk supply or trying to conceive a baby. Petitioners pray to the Madonna del Latte and a small amount of the powdered stone is purchased and mixed with supplicants' food. The small grotto's walls are lined with framed letters and pictures of babies pilgrims have sent from around the world testifying to perceived miraculous results.

${ }^{184}$ Rubin, Mother of God, 123.

${ }^{185}$ Johanna G. Seasonwein, "The Nursing Queen: Sculptures of the Virgo Lactans in Late Medieval France," (Ph.D. diss., Columbia University, 2010), 83.
} 
breast milk ... three drops of this milk remained on his face and he collected these and placed them in a precious vase appropriate for them." ${ }^{, 186}$ The cult caught on and flourished in Italy. For instance, in Montevarchi the Collegiate church houses a relic of Mary's milk. The relic was said to have been brought there by Count Guido Guerra in 1270 from the Middle East. The gift was commemorated in a narrative relief, adorning an exterior balcony, from which the sacred relic was displayed on its two yearly feast days. Carved by Andrea della Robbia, the relief features Count Guido Guerra, kneeling and presenting the precious milk-relic to ecclesiastical representatives of the church (fig. 2.2). ${ }^{187}$ The relief served as a visual verification of the legend, evidence of which does not actually exist. A polychromed terracotta sculpture of the Madonna lactans is installed in the Collegiate church of San Lorenzo. According to Megan Holmes, it was once set above the altar where the relic of the milk was kept, providing validation for the milk legend and a focal point for devotion. ${ }^{188}$ As Belting`s discussion of relics and images explains, the image in this context was not thought of as a likeness or an aesthetic illusion of the Virgin suckling her Son, rather worshipers would have understood it to have been a manifestation of a higher reality - indeed, "an instrument of supernatural power." 189 The nursing Madonna image would have been seen as a conduit, providing access to the thaumaturgic powers of the relic below it.

However, the cult of Mary's milk had its skeptics. Italian author and podestà Franco Sacchetti (d. ca. 1400) warned that deceptions about relics were the result of

\footnotetext{
${ }^{186}$ William of Malmesbury, El libro De laudibus et miraculis Sanctae Mariae, ed. Jose M. Canal, second edition (Rome: Alma Roma, 1968), quoted in Rubin, Mother of God, 138.

${ }^{187}$ Allan Marquand, Andrea della Robbia and his Atelier, vol. 1(Princeton: Princeton University Press, 1922), 123. http://catalog.hathitrust.org/Record/001981811.

${ }^{188}$ Holmes, 192.

${ }^{189}$ Belting, 47.
} 
avarice and that there was not a chapel around that did not claim to have the milk of the Virgin Mary. ${ }^{190}$ San Bernardino of Siena respected and praised the power of Mary's milk. For him, the least drop of the Virgin's milk "surpassed all fruits of the earthly Paradise and of the whole world." 191 Yet, he had no tolerance for the abuse of it.

And, oh, oh, by the way, the milk of the Virgin Mary! Ladies, where are your heads? And you, fine sirs, have you seen any of it? You know, they are passing it off as a relic. It is all over the place. Don't you believe it for a moment. It is not real. Don't you believe in it! Do you think that the Virgin Mary was a cow, that she would give away her milk in this way - just like an animal that lets itself be milked? ${ }^{192}$

San Bernardino extolled the virtues of the Virgin's milk on one hand and tried to extinguish the flame of false relic adulation on the other. But the cult of Mary's milk retained copious ardent supporters. Holmes pointed to a few other Madonna lactans images in the Montevarchi region of Tuscany as evidence that the cult of Mary's milk coincided with the image of the Madonna lactans. Counting the Collegiate church's terracotta nursing Madonna, she added some half length devotional panels attributed to the Master of the Adimari Cassone or Masaccio’s brother, "Lo Scheggia,” who had worked in the area, and a "very crude" painting in the Badia di Soffena just northeast of San Giovanni Valdarno, not far from Montevarchi, to the numbers of Madonna lactans images. Holmes concluded the Collegiate church terracotta Madonna lactans was specifically placed on the same altar as the relic, "providing a focus and structure to

\footnotetext{
190 “. .. La fede e buona e salve a ciascuno che l'ha, ma veramente solo il vizio dell'avarizia fa di molti inganni nelle reliquie; che e a dire che non e cappella che non mostri aver del latte della Vergine Maria.' Franco Sacchetti, Il Trecentonovelle, novella LX, ed. E. Faccioli (Turin: Einaudi, 1970), 156, http://www.letteraturaitaliana.net/pdf/Volume 2/t46.pdf.

${ }^{191}$ San Bernardino of Siena, Opera omnia, 2:381, quoted in Donna Spivey Ellington, From Sacred Body to Angelic Soul, Understanding Mary in Late Medieval and Early Modern Europe (Washington D.C.: The Catholic University of America Press, 2001), 133.

${ }^{192}$ Franco Mormando, The Preachers' Demons: Bernardino of Siena and the Social Underworld of Early Renaissance Italy (Chicago: University of Chicago Press, 1999), 102.
} 
devotion." 193 She also proposed that "The relationship between this relic of the Virgin's milk and Madonna lactans images would appear to have been close within the Montevarchi region." ${ }^{194}$ Oddly, Johanna Seasonwein deduced the opposite for France. "One might suppose that sculptures of the nursing Virgin would have been most popular in areas where one might find a relic of Mary's milk, but this does not seem to be the case. ... In fact, none of the sites [listed by Seasonwein] as repositories of milk are specifically associated with a sculpture of the nursing Virgin." ${ }^{195}$ It is difficult to say if the half-length panels Holmes mentioned were installed to support the cult as well, because their original locations were not available. They are now in private collections. ${ }^{196}$ While the Montevarchi region seems to have had both a proliferation of Madonna lactans images and an active milk-relic following, we know the same is not true everywhere. The "Milk Grotto" in Bethlehem is home to several Marian images; some are nursing and some are not. ${ }^{197}$ The artwork appears to have been installed at the shrine in the recent past, as visual support for devotion to the milk relic, the relic there actually took the form of the chalky white grotto itself. At milk shrines without Madonna lactans images the reliquary itself must have served as the visual object of devotion for supplicants. In Montevarchi, as at the Bethlehem shrine, the images appear to have worked in tandem with the relic; the images work as an instrument to reach the relic's miraculous power. As we shall discover, the Madonna lactans image served a variety of purposes for devotees. A chief factor in how people perceived the image had to do with

\footnotetext{
${ }^{193}$ Holmes, 192.

${ }^{194}$ Holmes, 192.

195 Seasonwein, 86.

${ }^{196}$ Holmes, 289, n. 74. The paintings are in Paris, Rome, and New York in private collections.

${ }^{197}$ Pictures of the Marian images at the grotto can be viewed at http://www.seetheholyland.net/milk-grotto/. There is a painted nursing Madonna sculptural piece above the entrance and a painted image inside the shrine. Statues of Mary without the Christ Child also populate the grounds. None of the images appear to date to the period of this study or earlier.
} 
the context in which it was viewed. But the constant factor was a desire for an

intercessor between the people and God.

\section{The Legend of Theophilus' Compassionate Intercessor}

Devoted milk-relic pilgrims who felt graced by the Virgin's intercession spread

their success stories, prompting growth in the numbers of ardent Marian followers.

Legends and images also served to promote the Virgin as a compassionate intercessor.

The legend of Theophilus and the subsequent images advanced devotion to her. Relayed in numerous sources, the oft-told story recounts how Theophilus entered into a pact with the devil to further his career. ${ }^{198}$ Later, filled with regret, he prayed in front of a statue of the Virgin, entreating her to intervene. She came to his rescue with the relinquished pact in hand. Devotion to her became enormously widespread when Theophilus himself made the story public, spreading the news of the Virgin's intervention. The story is depicted in relief carvings on cathedrals across Europe and in period manuscript illuminations. ${ }^{199}$

Note that Theophilus prayed before an image of the Virgin. The image was a vital ingredient to devotion in this tale because of the Virgin's role as intercessor in it. The concept that the Virgin was a powerful intercessor is an important consequence for the

\footnotetext{
${ }^{198}$ Emile Mâle, Religious Art in France in the Thirteenth Century, trans. , Dora Nussey (New York: E.P.Dutton \& Co., 1913), 261. Mâle listed Honorius of Autun's (d. ca.1130) sermon Speculum Ecclesiae as a source, which was used as an "example." Mâle explained the legend had Eastern origins, translated from Greek into Latin by Paulus Diaconus. An anonymous Italian version, Miracolo di Teofilo is cited in Moshe Lazar, "Theophilus: Servant of Two Masters. The Pre-Faustian Theme of Despair and Revolt," MLN, Vol. 87, No. 6, November, 1972, 33; Jacobus de Voragine (The Golden Legend) and Gautier de Coincy (in verse) are authors of the tale, and Rutebeuf is a thirteenth century playwright of the tale. See Michael T. Davis, "Canonical Views: The Theophilus Story and the Choir Reliefs at Notre Dame," in Reading Medieval Images, eds. Elizabeth Sears and Thelma K. Thomas (Ann Arbor: University of Michigan Press, 2002), 103. The tale was versified in Latin by Saxon canoness Hrotsvitha in the tenth century. See Rachel Fulton, From Judgment to Passion: Devotion to Christ and the Virgin Mary 800 -1200 (New York: Columbia University Press, 2002), 539, n.62.

${ }^{199}$ For examples the narrative is in the sculptural programs of cathedrals of Notre Dame at Lyons and Souillac and in the windows at Chartres, Laon, Beauvais, Troyes, and Le Mans. Mâle, 260. The legend is also depicted in the Escorial Manuscript of the Cantigas de Santa Maria (ca. 1280). Davis, 111.
} 
Madonna lactans: because she nursed her Son, people embraced the belief that she would be refused nothing when she brought her followers' requests to God. Images of Mary indicating her breast as a gesture of intercession will be discussed in chapter four. Let us return to our exploration of how habits and devotional rituals to the Virgin were formed and what the consequences were for devotion to the Madonna lactans image.

\section{Marian Architectural Programs, Feasts, and Legends}

A combination of factors stimulated fervor for Mary. The early centuries of the second millennium saw a doubling of the population in Europe. ${ }^{200}$ Europeans put down roots, creating villages and cities. Miri Rubin asserted, "The development of a robust religious culture in the thirteenth century, with Mary increasingly at its heart, was made possible thanks to the growth and wealth of European communities, especially the towns and the cities. Italian cities produced new impulses in religious life." ${ }^{201}$ Churches were established and because the Virgin above all other saints was familiar and loved, the churches were dedicated most often to her. Most European cathedrals and churches dedicated to Mary were founded between 1000 and $1200 .^{202}$ Additionally, Marian feasts were added to the liturgical calendar and celebrated with regular frequency during this period. Feasts like the Annunciation, the Visitation, and the Coronation were the subjects of exterior architectural sculpture decorations, which began to adorn the churches and cathedrals across Europe in the twelfth century and continued into the following centuries. These exterior decorations were the media images that bolstered the increasing numbers of Marian tales. Stories appeared in the escalating number of literary works

\footnotetext{
${ }^{200}$ Robert Bartlett, The Making of Europe: Conquest, Colonization and Cultural Change 950 - 1350 (Princeton, NJ: Princeton University Press, 1993), 2.

${ }^{201}$ Rubin, Mother of God, 197.

${ }^{202}$ Rubin, Mother of God, 131.
} 
dedicated to the Virgin, and many became available to lay populations in the native tongue as texts were translated from Latin. ${ }^{203}$ When encountered in the vernacular Mary was familiar and easily embraced, which added to her star status.

The eleventh century saw the first written collections of her miracles, and the widespread practice of storytelling put her in the role of popular heroine. ${ }^{204}$ The Golden Legend of Jacobus de Voragine and Miracles of the Blessed Virgin Mary by Johannes Herolt (called Discipulus), were compiled in the thirteenth century. Mary's maternal mercy was reflected in the miracle stories, which she performed for the benefit of pious priests, sinners, nobles, and impecunious plain folk alike. The stories were relatable to everyone, and they generated a following. For example, a tale chronicled in the Miracles' pages tells of a country woman who praised Mary every day, and when she brought her husband lunch in the field she appealed to the Blessed Virgin to watch her baby. "I have no one to put in charge over my child except thee," she prayed. One day while she was away, a fire broke out and burned her house to the ground. "Grieving more for the boy than for the house and the loss of their goods the mother cried out: ' $\mathrm{O}$ Blessed Virgin, to thee I entrusted my son.' And they searched for the child and found him entirely unhurt."205 The woman's devotional loyalty to the Virgin inspired the Virgin's loyalty in return. Stories like this one multiplied the numbers of Marian devotees. Written in the early fourteenth century, the popular Meditations on the Life of Christ portrayed Mary as an ordinary woman going about the daily chores of any mother.

\footnotetext{
${ }^{203}$ Rubin, Mother of God, 199.

${ }^{204}$ Andreas Petzold, Romanesque Art (New York: Harry N. Abrams, Inc., 1995), 124. Rubin, Mother of God, 187.

${ }^{205}$ Johannes Herolt, Miracles of the Blessed Virgin Mary, trans. C.C. Swinton Bland (New York: Harcourt, Brace and Company, 1928), $33-34$.
} 
Mary was featured likewise in collections of miracle plays ${ }^{206}$ and in "The Prioress's

Tale" from Geoffrey Chauser's The Canterbury Tales of the late fourteenth century.

\section{The Virgin's Roles and Guises}

As images of the Virgin increased in number, she was portrayed in a greater variety of roles. For instance, in the apse mosaic in Santa Maria in Trastevere in Rome (1140s) she takes her place, sharing a throne with Christ, where they are featured side by side, virtually as equals with their heads in line (this arrangement is called Isocephalus). The mosaic program is based on one from the sixth century church of Saints Cosmas and Damian, where a Byzantine mosaicist executed the image. In another role, a carving of the Virgin holding an apple can be found in Sieberg, Germany (ca. 1160), identifying her as the new Eve, pure, sinless, and obedient. The celebration of the Virgin's life in various roles and her feasts can be seen in vivid narratives across Europe. ${ }^{207}$

Increasingly, poetry and manuscript illuminations were made for and by women and many reflect a feminine perspective. In the Annunciation scene found in the St. Albans Psalter (1120-30) commissioned for Christina of Markyate, a visionary nun and prioress at St. Albans, there is a noteworthy innovation in the iconography of the Virgin (fig. 2.3). The Virgin is reading a book - not mentioned in the biblical text - which presents an intellectual role model for women. The increase in literacy at this time among nuns and noble women was reflected by the iconographic detail of the Virgin

\footnotetext{
${ }^{206}$ Miracles de Nostre Dame par Personnages, publiés d'après le manuscrit de la Bibliothèque nationale, ed. Gaston Paris and Ulysse Robert (Paris: Firmin Didot et cie, Société des anciens textes français, 187693).

${ }^{207}$ For example in Rome, Santa Maria Maggiore is adorned with a mosaic program featuring the Annunciation, the Adoration, and the Presentation. In France the Annunciation, Visitation and Adoration of the Magi adorn the south portal of St. Pierre at Moissac.
} 
reading a book. This example speaks to the nature of the relationship between images of the Virgin and the patrons that engaged with them. That women were patrons, abbesses, literate noblewomen and queens can be perceived through book and manuscript illuminations from this period. Matilda of Canossa (d. 1115) was one such art patron and ruler. She ruled over the territories of Tuscany and Emilia. Her biographer, a monk called Donzio, emphasized her peacemaking activities and her daily recitation of the Office of the Virgin. She commissioned an illuminated Gospel book made in the late eleventh century at a Cluniac monastery near Mantua in which scenes from Mary's life are illustrated. ${ }^{208}$ These scenes supplied people with a projection of an ideal, presenting Mary as an exemplum.

A further interesting example of Mary presented as an ideal can be found in another manuscript illumination. Labeled Theotokos - "Mother of God" - the Virgin is depicted in a Cistercian manuscript made at Cîteaux in about 1130, the period just after St. Bernard had resided there. It features a colored ink drawing of the Tree of Jesse and in the central illustration we have an early Madonna lactans motif (fig. 2.4). Sitting in a roundel composed of climbing vines a majestic, motherly Madonna offers the Christ Child her ample breast. She is surrounded by the three Hebrews in the fiery furnace (Hananiah, Azariah, and Mishael), as well as Moses, Daniel, and Gideon. The drawing marries the Old Testament with the promise of a New Covenant. Mary is prominently featured in the Tree of Jesse, for in the eyes of the Cistercians who sponsored this early Madonna lactans image, the salvation story depended upon Mary's role as provider of sustenance. The Tree of Jesse is a visual representation of the ancestry of Christ. It

\footnotetext{
${ }^{208}$ Petzold, 39 - 40. See for example MS M.492 fol. 59r. Zones 1 - 3, Corsair, Pierpont Morgan Library, http://utu.morganlibrary.org/medren/single_image2.cfm?imagename=m492.059r.jpg.
} 
typically portrays a series of kings of the Davidic line, prophets and the evangelists. ${ }^{209}$ While most medieval representations include the Virgin and Christ at the top, the nursing motif is an unusual one. ${ }^{210}$ This is a fascinating detail, and it is tempting to point to Saint Bernard's sermons and writings about Mary and the mystical qualities of her breast milk as an impetus. Certainly it was created in close proximity to the monk, who lived at the Abbey of Citeaux until ca.1115. ${ }^{211}$ Already the cult of Mary's milk was established and gathering devotees, which likely increased, in part, due to his writings about its power. It is reasonable to point to St. Bernard's influence and perhaps this resulting early manuscript illumination as a touchstone for devotion to the nursing Madonna image, which caught on slowly but steadily.

\section{Public Marian Devotion in Late Medieval Italy}

\section{Siena and the Virgin}

In Italy devotion to the Virgin increased when she was believed to have interceded on behalf of entire cities, defeating the enemy in battle. In 1260 Siena was threatened by the Florentines. The day before an important battle, Buonaguida Lucari famously and quite publicly urged a Sienese crowd to join him in giving the city of Siena to the protection of the Virgin. He led the crowd, "barefoot and penitent" to the cathedral where he met the bishop. Hand-in-hand they processed to the high altar where Buonaguida prostrated himself before the altarpiece image of the Virgin, addressing her.

\footnotetext{
${ }^{209}$ Johann G. Roten, S.M., The Jesse Tree, The Marian Library/International Marian Research Institute, The University of Dayton, http://campus.udayton.edu/mary/meditations/jessetree.html.

${ }^{210}$ Petzold, 131. "An isolated example of its [the Virgo Lactans] use . . . occurs in a Cistercian manuscript made at Citeaux in about 1130." A literal interpretation of the nursing motif might be applied. That is, perhaps Mary's immediate role in the long line of Christ's ancestry is symbolized by the act of maternal feeding. The rare application of the motif and the proximity to St. Bernard is noteworthy, however.

${ }^{211}$ St. Bernard of Clairvaux, Catholic Encyclopedia, http://www.newadvent.org/cathen/02498d.htm.
} 
He bequeathed and pledged the city and its contado to her and petitioned her to guard the city and its citizens from "the iniquitous and evil dogs, the Florentines." 212 The battle of Montaperti against the Florentines ensued the next day. The Sienese achieved an unexpected and crushing victory, an event which is still prominent in the consciousness of modern Sienese citizens. ${ }^{213}$ From that day forward, Siena would forever be dedicated to the Virgin and the historical event is commemorated every year with the feast of the Assumption. ${ }^{214}$ Like Theophilus, Buonaguida and the crowd made the petition before an image of the Virgin. The feast is celebrated using that altarpiece image as a focal point in processions and elaborate candle ceremonies. Devotion in this guise is public, even theatrical.

In general, the altarpiece image served as scenery, as a backdrop during the theatrical celebration of the Mass in late medieval Europe. It also was the trigger for contemplative devotional practices as people attended Mass. The nursing Madonna as an altarpiece decoration served as a powerful impetus for introspective meditation popularized in this period, as we shall see in the following chapter. Dramatic devotion had its counterpoint when practiced privately.

\footnotetext{
${ }^{212}$ Diana Norman, Siena and the Virgin: Art and Politics in a Late Medieval City-State (New Haven \& London: Yale University Press, 1999), 3. These events are recorded in manuscripts held in the Biblioteca Comunale Siena, MS A IV 5, fol. 4and published in Giusseppe Porri, La sconfitta di Montaperto, narrazione storica tratta da un antico manoscritto con note, 1442 - 3 (Siena, 1836) 43 - 44.

${ }^{213}$ Norman, 4. For scrutiny of these historical events see Edward B. Garrison, "Sienese Historical Writings and the Dates 1260, 1221, 1262 applied to Sienese Paintings," in Studies in the History of Medieval Italian Painting (London: Pindar Press, 1993), Vol. 4, 23-58 and Diana Webb, Patrons and Defenders: The Saints in the Italian City States (London \& New York: Tauris Academic Studies, 1996), 251- 75.

${ }^{214}$ The celebration is several days long including parades, festivities and a horse race (il Palio). The Palio is run in observation of a local feast honoring the Madonna of Provenzano. Provenzano Salvani is said to have seen an apparition of the Virgin Mary. Legend has it that a painted image of the Madonna of Provenzano in the church of the same name has miraculous curative powers and has been the object of votive offerings and pilgrimages for centuries. Again the prominence of the image is notable. http:// www.ilpalio.org.
} 


\section{Late Medieval Private Marian Devotion}

The Gothic period's proclivity toward smaller, privately owned images demonstrated a belief in the power of the image. Private Marian devotion was tied to the formulation of the owner's identificatory relationship with images of her. The tendency was toward a personification of an accessible Virgin to whom people could relate. Endowed with great emotional appeal, small renditions of the Pietà are examples of an impetus for personal devotional activity (fig. 2.5). ${ }^{215}$ The depiction of the Virgin grieving her dead son inspired pity and compassion in the devotee. The depiction of its counterpart, the Virgin suckling her newborn Son, was profoundly inspirational as well. The nursing Madonna image told the beginning of Christ's history - the story of the Incarnation - full of hope and of the promise of a Savior fulfilled. The Pietà depicted the earthly end of the story - the culmination of Christ's mission. These were the alpha and omega images of Christ's human Incarnation in salvation history. Neither moment is described in Scripture, but both are related in the late medieval "best seller" Meditationes vitae Christi.

\section{Meditations on the Life of Christ}

This dynamic retelling of the Gospel encouraged late medieval readers to visualize themselves present at the scenes the author described. ${ }^{216}$ But even before the

\footnotetext{
${ }^{215}$ Andachtsbild is German for devotional image, and Germany played a role in the development of the use of portable images for contemplation. Sculpted souvenirs bought on pilgrimages to the Holy Land played a role in the rise of the practice as well. Michael Camille, Gothic Art: Glorious Visions (Upper Saddle River, N.J: Prentice Hall, 1996), 115 - 119.

${ }^{216}$ Michael Camille argued about the Gothic perception of time and space: "Meditations on the Life of Christ encouraged people to visualize themselves as present at major events in Christ's life, to project themselves into history. . . . with the help of art, it is possible to travel [backward] in time," Camille, Gothic Art, 92. Henk van Os stressed the importance of the advice to meditate upon the events recounted in Meditations for the production and practical use of devotional images in the late Middle Ages in his The
} 
Meditations was written, Anselm of Lucca (d.1086) suggested a novel approach to private prayer to the Virgin. He taught the practice of delving inward, using one's interior eye as an aid to efficacious contemplative prayer to the Virgin. He advised Countess Matilda of Tuscany to pray to Mary, meditating on the Virgin's most intimate moments, "and not from a distance ... but with her interior eye, as if Matilda were present as an eye-witness ..."217 This sort of intimate empathy and contemplative vision is the key to understanding late medieval devotion to Mary and how images of her facilitated that devotion. Devotional practice required an active engagement of the senses.

\section{Franciscan Spirituality and Meditative Practices}

St. Francis of Assisi (1182 - 1226) is the era's best model of empathetic devotion. As the father of the widely popular mendicant order, he embraced Christ-like poverty and, aspiring to imitate Christ's suffering, is said to have prayed before an image of the crucified Christ, asking for and receiving the stigmata. Here physicality merged with contemplative prayer before an image. Enormously popular, Franciscan spirituality emphasized Christ's humanity and embraced fervent devotion to his human mother, Mary. These factors intensified the profoundly physical aspect of late medieval spirituality, and when coupled with meditative interaction with images, devotion became actively collaborative. Devotees used images, fully engaging the mind, body and soul in

Art of Devotion in the Late Middle Ages in Europe 1300-1500 (London: Merrell Holbertson, 1994), 12 14. See also chapter one above.

${ }^{217}$ R. Fulton, 226. For more on this medieval contemplative practice see Camille, 11. Margaret R. Miles, Image as Insight, 96. David Chidester, Word and Light: Seeing, Hearing, and Religious Discourse (Urbana and Chicago: University of Illinois Press, 1992), 3-6. Chidester summarized how ancient Greek philosophers explained optical theory. Although philosophers' theories differed, all relied upon a relationship between organ and object. See also chapter one of this study. 
every sense of these words. But the idea was for the image to be a fascilitator, or a means to deeper spirituality.

In Francis's native Italy the Virgin was humanized in various guises. In one popular image-type she is holding her Son with his cheek pressed to hers in an arrangement called Glykophilousa; they are often portrayed without haloes in this type of image. The Madonna suckling the Christ Child is called Galactotrophousa. Glykophilousa is a Greek term meaning "the one sweetly kissing." It was first seen as a Byzantine representation and was later adopted in the West, especially as images of the warm interaction between Christ and his mother became popular. Galactotrophousa, is the Greek name for the Madonna lactans type. Victor Lasareff demonstrated the Eastern pedigree of the lactans image, as noted in the Introduction of this thesis. ${ }^{218}$ The Byzantine derivation of the lactans image is significant to our study because the belief that the image was imbued with mystical power was developed in Eastern Christian thought. The Eastern Church embraced an image-centered theology. An icon actually held some of the divine power of its prototype. ${ }^{219}$ While this belief was not officially conveyed to Western Christian thought per se, we certainly witness ardent devotion directed to the person the image replicates. Late medieval and Renaissance people seemed to have confused this distinction at times. Devotion to an image was not the aim. Devotion to the saint in the image was. However, as this chapter reveals, and subsequent devotional practices directed toward the nursing Madonna will also will show, people sometimes behaved as if the image had the power. The more human portrayal of Mary, which went hand in hand with her textual portrayal, stimulated devotion in exceedingly

\footnotetext{
${ }^{218}$ Lasareff, $30-36$.

${ }^{219}$ Camille, Gothic Art, 103.
} 
greater numbers of people. The more human she appeared, the more accessible she seemed to people. When people saw her nursing they could relate to her.

Meditations on the Life of Christ had a powerful impact upon late medieval people, and copies were passed down through generations. The title hints at the active mental participation in which the author entreated readers to partake, urging meditation on the vivid retelling of the New Testament stories. One example is particularly salient here: the Franciscan author prompted readers to consider Mary’s viewpoint as they “... Watch her attentively as she cares for Him assiduously, and wisely, nursing and rendering all services. ${ }^{220}$ The author extolled the virtuous act of Mary nursing her Son and encouraged the devotee to "watch" as if he or she were actually present. These texts were undoubtedly one of the influential impetuses for the visualization practices undertaken by people, particularly nuns, as they engaged with the Madonna lactans image. The prominence of imagining physical presence in late medieval spirituality and the goal of mimesis also encouraged engagement with images. As the perfect foil to the Pietà, the Madonna lactans exemplified intimate shared physicality, and it embodied the aspect of Franciscan self-sacrifice, the imitation of which in this case, of course, was achievable for women alone. Women required an example of behavior worthy of imitation. They should be sinless, unlike Eve; she should be literate, like the Mary shown reading in the St. Alban's Psalter illustration of the Annunciation; she should be obedient also like Mary Annunciate; and she should be a good, selfless mother like the nursing Madonna.

\footnotetext{
${ }^{220}$ Ragusa and Green, 55.
} 


\section{Marian Devotion in Renaissance Italy}

The perceived power elicited from devotees' interaction with Marian images was also a chief element of Marian devotion during the Renaissance period, and the Virgin's power (through images of her) was active in the minds of Renaissance Italians. They believed that she blessed the outcome of battles, cured the ailing, brought rain after drought, and bestowed mercy on those in need of it. Examples of devotion using images are evident through chronicles and records from the period and are manifest in public and private rituals, as in the earlier period. And although private devotion is more subtle by its very nature, the fevered pitch of Marian devotion seems to reach a new high in the spectacle of embracing Mary in public. The spectacle of public processions with Marian images had the appearance of a celebration or a festival, but the presence of ex-voto offerings at the foot of these shrines indicates a greater purpose. Participants reveled in the festivities, but they appealed to Mary for help, too. Private devotion appears to have encouraged intimacy and an increased degree of closeness to the Mother of God, yet the pursuit of intimacy was not for its own sake. Primarily, each ritual reflected people's desire for Mary's help and intercession. In return for ardent devotion to Mary, Renaissance Italians were seeking favors. We shall examine a public ritual and some examples in which Renaissance Italians engaged with images of Mary for private prayer.

\section{Public Marian Devotion Rituals}

\section{The Madonna's Cult Status}

Renaissance Italy saw the development of devotion to the Virgin Mary that reached cult status. The image of Our Lady of Impruneta has a centuries-long historical 
record, enabling a study of Florentines' devotion and reception ${ }^{221}$ (fig. 2.6). Records divulge ardent belief in the image's miraculous powers as it was paraded through the streets of Florence. $^{222}$ The image was credited with making it rain after long droughts and with victorious outcomes in battles. The most telling sanction of belief in Our Lady of Impruneta's miraculous power was the behavior of her ardent devotees. The procession of her image attracted large crowds. There is an account of 25,000 people crowding the main piazza of Florence and people leaning from windows as the image was paraded by. ${ }^{223}$

One more illustration of a cult forming around a Marian image will provide insight into how burgeoning devotional activity formed around images, including a Madonna lactans cult. On a summer night in 1501 a truculent Antonio Rinaldeschi left The Fig Tree, a Florentine tavern, where his gambling losses had been considerable. Swearing and cursing the name of the Virgin, he spied some dried horse dung and flung it at the Virgin's face in a Virgin Annunciate fresco, painted in a tabernacle niche on the side of S. Maria degli Alberighi - a church in the piazza. Hoping his impetuous gesture would go undetected, he fled to a Franciscan convent outside the city's walls. A piece of the odious lump, resembling a rosette, broke off and stuck to the Virgin's diadem. Much ado was made of the offending vandalism. The archbishop came to inspect it. People placed votive images and candles before the fresco of the Virgin called the Madonna de'

\footnotetext{
${ }^{221}$ Richard C. Trexler, Public Life in Renaissance Florence (New York: Academic Press, 1980), 63 - 68. Trexler consulted such sources as Cronichette Antiche di Varii Scrittori del Buon Secolo della Lingua Toscana, ed. D. Manni (Florence, 1733) and Landucci, Luca, Diario Fiorentino dal 1450 al 1516, continuato da un Anonimo fino al 1542, ed. I. Del Badia (Florence, 1969) to name a few. ${ }^{222}$ See Trexler, $63-66$.

${ }^{223}$ Trexler, Public Life, 66. The image was kept veiled in a church by the same name about six miles outside of Florence. On special feast days and in times of dire need, the image was paraded through the streets into Florence. The procession of the image appeared to be the Virgin's call to action, prompting her miraculous help as if suddenly "on duty."
} 
Ricci, and it rapidly became the object of popular devotion. Miracle stories arose. In the following days, the bishop ordered the fresco to be cleaned but either it was not cleaned entirely or the offending "rosette" reappeared on it as a sign. ${ }^{224}$ Filippo Dolciati painted a record of the events in 1502, which is now in the Stibbert Museum in Florence (fig. 3.7 and 3.8). In the painting as in numerous records, all of which agree on the chief details of the story, Rinaldeschi was caught, confessed, attempted suicide, received absolution from a priest, and then was hanged from the Bargello windows. The fresco image became the locus of a burgeoning devotion. The number of devotees grew to the point that it became necessary to build crowd control structures around the fresco. Initially an oratory was built and ultimately a more imposing building was begun in 1507 to accommodate the still-growing cult. ${ }^{225}$ The fresco was removed from its original spot in 1771 and was suspended above the main altar where it hangs today. The fact that Our Lady of Impruneta was a refined painting and the Madonna de' Ricci fresco was a crude execution had little bearing on the fervor of the devotees. Both images attracted crowds, both were credited for miracles, and both amassed valuable offerings. In Renaissance Italy devotion to the Virgin through her images was fervent and sometimes fanatical. Devotion to images in public places, like that for the Madonna de' Ricci, occurred rather commonly in Renaissance Italy, but devotional activities could also be quite private. Observing private devotion as it takes place is, of course, problematic. The witness would have to be out of sight and a record is necessary.

\footnotetext{
${ }^{224}$ William J. Connell and Giles Constable, "Sacrilege and Redemption in Renaissance Florence: The Case of Antonio Rinaldeschi," The Journal of Warburg and Courtauld Institutes, Vol. 61 (1998), 53-54. The authors scoured Florentine archives concerning Rinaldeschi, his trial and execution brought about by magistracies and Florentine security - the Podesta and The Eight respectively.

${ }^{225}$ Connell and Constable, 83.
} 


\section{The Intersection between Public and Private Marian Devotion in Renaissance Italy}

\section{Roadside and Street Corner Shrines}

The Tuscan countryside is home to at least one tabernacle fresco of the Madonna lactans image (ca. 1450), and it stood on land once owned by the Confraternity of the Virgin's Milk, just outside the town of Montevarchi. Celebrated for being responsible for miracles, it became the object of cult worship in $1585 .{ }^{226}$ Crowds of devotees seeking Mary's intercession gathered there to pray, and when prayers were answered people brought votive offerings in thanksgiving. Like the cult devotion consigned to Our Lady of Impruneta and the Madonna de' Ricci, when people received miraculous answers to their prayers, the outdoor Madonna lactans shrine began to attract its own enthusiasts. The outdoor tabernacle image is a locus for both public and private devotion. Because of its location out in the open, devotional prayer before it might be witnessed or shared, especially when it became the object of a cult. On the other hand, the ordinary nature of private prayer before roadside and street corner shrines might relegate it to the category of unnoticed or unremarkable activity, making private devotion feasible.

Popular author Frances Mayes wrote a memoir about her experiences and observations when she moved from California to the Tuscan countryside outside Cortona late in the twentieth century. She chronicled her observations of devotional activity before a Marian roadside shrine at the end of her long driveway. Observed behavior has long served studies in a range of disciplines. The record below is just that - observed behavior. Mayes's testimony is credible and serves our purposes, filling a void, for there are no other such recorded observations before countryside shrines. Earlier, Italian

\footnotetext{
${ }^{226}$ Holmes, 192 and 289, n. 73.
} 
historian Lauro Martines wrote in praise of this sort of fact finding. "[Historians] use the stories of others .... wherever we find sustained historical testimony, there the resource of language - or of semiotic systems such as ritual - are being used to convey meaning but also to present narrative structure."227 Martines was referring to period tales; the following narrative is an eyewitness account.

In the popular memoir Under the Tuscan Sun Frances Mayes described a view from high above as she stood in her garden. She could see an old stone niche with a white porcelain statue of the Virgin against a blue background, in the della Robbia style, at the intersection of the bottom of her long driveway and the country lane leading to Cortona. ${ }^{228}$ Of particular interest was the activity in front of this small statue of the Virgin, where fresh flowers appeared nearly every day. She wondered was leaving the flowers. Monitoring the comings and goings, she described seeing a middle-aged woman on a battered bicycle stop. Before long a stooped woman in a red shawl ambled up, kissed her fingertips and touched the statue. Later a young man jumped out of his car for a brief visit and then roared off. Finally she spied the daily donor of wildflowers. An elderly gentleman approached on foot, walking slowly and with dignity. He stopped to pick a handful of whatever was growing incidentally nearby. He varied the selection every time, each day offering the porcelain Virgin a new bouquet. The author mentioned that she never watched him after he arrived when he prayed before the shrine. The instinct to let private devotion be private is an interesting aspect of the account. The opportunity to observe private devotional activities is by definition, rare.

\footnotetext{
${ }^{227}$ Lauro Martines, "The Italian Renaissance Tale as History," in Language and Images in Renaissance Italy, ed. Alison Brown (Oxford: Clarendon Press, New York: Oxford University Press, 1995), 313. ${ }^{228}$ Frances Mayes, Under the Tuscan Sun (New York: Broadway Books, 1996), 41-42.
} 
This narrative is the only eyewitness account I was able to uncover, of the activity in front of one of the thousands of devotional niches or frames (capitello) holding images of Mary, the saints, and Christ, which dot street corners and country lanes all over Italy. Although written in the twentieth century, the activity is likely the very same as it was since the roadside devotionals' beginnings. Historians have traced their origins to the trecento. ${ }^{229}$ The shrines comprise a portion of Italian devotional culture too pervasive to ignore. Although the street corner Madonna exists in a very public venue, the devotional activity can be quite private. There are not throngs of people present; these are not festival images, nor "grand marshals" of parades carried through the streets. Devotion before these images exemplifies a practice in which public and private devotion intersect. While the voyeuristic activity of the twentieth-century author allowed a peek at devotional behavior on a particular country lane, it is safe to assert that the recorded devotions were performed unselfconsciously; the devotees did not appear to know that their deeds were being observed and documented. In fact, even the author looked away at the most intimate moment. The devotion was not theater.

There are instances where the demonstrative aspect of personal piety might have been the goal, however. The urban street corner shrine was the locus for such a ritualistic display. The intimacies and complexities of Italian Renaissance urban society should be

\footnotetext{
${ }^{229}$ Edward Muir and Ronald F. E. Weissman, "Social and Symbolic Places in Renaissance Venice and Florence," in The Power of Place: Bringing together Geographical and Sociological Imaginations, John A. Agnew and James S. Duncan, eds. (Boston: Unwin Hyman, Inc., 1989), 95. During the fourteenth century the Venetian Council of Ten tried to pacify street behavior by having sacred images in capitelli installed every few hundred paces. "A picture of the Madonna would force would-be combatants to stop and show reverence." See also Edward Muir, "The Virgin on the Street Corner: The Place of the Sacred in Italian Cities," in Religion and Culture in the Renaissance and Reformation, Steven Ozment, ed. (Kirksville, Mo.: Sixteenth Century Journal Publishers, 1989), vol. IX, 25. The republic of Florence charged local patricians with the responsibility of watching over these neighborhood images, beginning in 1450 . Very little has been written about these ubiquitous street corner images, and observed behavior of devotees went unrecorded for centuries.
} 
considered when assessing the motive for a showy display of devotion. Edward Muir suggested that devotion took the form of theater under the watchful eye of neighbors. “... [T] he ubiquity of the images may point to a social style characterized by formality and the pervasiveness of ritual and theatricality of daily life. ${ }^{230}$ In Renaissance Italy the parish and its piazza-based neighborhood was not just a geographical location. It was the basis for social identity, and the piazza a stage upon which that social identity was formed. More than one historian has asserted that Italian social organization and Renaissance Florentines' self-identity revolved around the neighborhood and its parish, or, as Klapisch-Zuber put it, kin, friends and neighbors. ${ }^{231}$ Appearances in the neighborhood were essential factors in influencing one's prestige, reputation, status, and ability to participate in politics in the fifteenth century. ${ }^{232}$ The loyalties and intimacies of neighborhood political culture were formed in the parish, the nucleus of the neighborhood. ${ }^{233}$ Kinsman, friend, tax assessor, political ally, and business partner were roles Florentine - and surely all Italian - men played. ${ }^{234}$ Muir and Weissman asserted that citizens consciously acted or performed to fit these roles. "Accomplished citizen-

\footnotetext{
${ }^{230}$ Muir, 25. Muir is not the only scholar to refer to prayer before devotional art works as theater. Henk van Os stated, "Works of art, used for prayer often evoke an intimate spiritual theater." His use of the word 'intimate' puts his theater into a more private context, however. See Henk van Os, Visions of Holiness: Art and Devotion in Renaissance Italy, eds. Andrew Ladis and Shelley E. Zuraw, introduction by Henk van Os (Athens, GA: Georgia Museum of Art, University of Georgia, 2001), 11.

${ }^{231}$ Christiane Klapisch-Zuber, "Parenti, amici, e vicini: il territorio urbano d'una famiglia mercantile nel XV secolo," Quaderni Storici , XXXIII, 1976, 953-82.; Dale V. Kent and Francis William Kent, Neighbours and Neighbourhood in Renaissance Florence: The District of the Red Lion in the Fifteenth Century (Locust Valley, N.Y.: J.J. Augustin, for Villa I Tatti,1982); Muir and Weissman, 88-89.

${ }^{232}$ Muir and Weissman, 88-89. See also Francis William Kent, Household and Lineage in Renaissance Florence: The Family Life of the Capponi, Genori and Rucellai, (Princeton: Princeton University Press, 1977); Robert Finlay, Politics in Renaissance Venice (New Brunswick, NJ.: Rutgers University Press, 1980).

${ }^{233}$ Beyond providing spiritual guidance, parishes served as small units of civil administration where minor civil disputes were sorted out. For example Kent and Kent demonstrate how ruling members of the Red Lion gonfalone delegated tax collecting responsibilities to the Vallombrosan abbot of San Pancrazio, the ward's principal church, 6, 128-129.

${ }^{234}$ Muir and Weissman, 89-90; Kent and Kent,108.
} 
actors communicated messages by following certain patterns as they moved about the city's spaces. . . The signifying power of the city's places was most dramatically magnified by the touch of the sacred."235 Little outdoor shrines were one example of this "touch of the sacred," and the performance of prescribed gestures in front of the shrines was for show, according to Muir and Weissman. Furthermore, Muir maintained religious behavior was another form of business negotiation. Therefore status, political posturing, business success, and one's piety and self-identity in the neighborhood were all inextricably linked, and an emphasis upon appearances was vital. Muir concluded, "The Virgin hovering in every street required a performance, and even for the pious the most important thing was to bring it off.,"236

Muir's hypothesis is based on a good deal of research about the importance of appearances in Renaissance Italy's urban neighborhoods. Yet, his conclusions apply only to elite Florentine males who would be subject to the impressions of observable nuanced behaviors as they apply to business dealings and political aspirations. Muir does not account for the meaning and function of the corner shrine for the rest of the population: women, the working-class, and the aged - all socially marginal citizens, to which business dealings and political aspirations were out of reach. Their behavior likely went unscrutinized. Again, no actual record of the performance of rituals in front of street corner images of the Virgin from the Renaissance era exists. Muir could be exactly correct about the requisite pious performance for the gentry, but devotees of every class also conducted private personal prayer rituals before the Virgin's street corner likeness. In any case, demonstrations of reverent behavior must have been as varied in a city

\footnotetext{
${ }^{235}$ Muir and Weissman, 93-94.

236 Muir, 29.
} 
setting as they were to our recent eyewitness in the country. For hundreds of years it is likely that some people may have stopped only for a moment, while others' daily habit of bringing an offering was as routine as stopping for a morning caffé. Because we have an unequivocal modern description of devotees' behavior before a roadside shrine, and we have the witness involuntarily looking away from the intimate moment of prayer (albeit in the twentieth century, and in the countryside), I argue that for most people, devotional behavior before images on the street corner was and remains a closer cousin to private devotion than to the public display we have seen during a festival or procession where theater was the order of the day.

\section{Private Marian Devotion in Renaissance Italy}

\section{Madonna in the Bedchamber}

Private devotion generally refers to devotional activities conducted in solitude. ${ }^{237}$

Evidence of this common activity can be measured by the great numbers of surviving small images of the Virgin and Child, commissioned and produced especially for personal devotion. The response to consumer demand for this type of image was met by the replication of them, which was a fundamental aspect of artistic practice in the fourteenth century and especially the fifteenth-century Italian workshop. ${ }^{238}$ Thus private

\footnotetext{
${ }^{237}$ This section will chiefly examine devotional activity before images in private homes, where the Madonna with Child was devotional art's most common subject. There are endless possibilities as to where else this personal activity took place. For example, prosperous citizens sometimes had private chapels in their homes. Devotional images also hung in convent and monastic cells and were naturally used for private devotion. Private devotion likely took place in the side chapels of public churches and, as we have seen, before street corner icons. Presently we will also examine evidence of devotional prayer, which took place as the devotee walked about.

${ }^{238}$ Ronda Kasl, in Giovanni Bellini and the Art of Devotion, Ronda Kasl, ed. (Indianapolis: Indianapolis Museum of Art, 2004), 4. See also Andrea Golden, "Creating and Re-creating: The Practice of Replication in Giovanni Bellini's Workshop," in the same volume, 91 - 93. Rona Goffen has estimated there are more than eighty variations of Bellini's Madonna and Child theme known today. Rona Goffen, Giovanni Bellini,
} 
devotional practice relied upon images just as heavily as did public devotion to the Virgin. Such images evoked deep emotion in those who prayed. They encountered a close-up view of the Virgin and her Son in the personal setting of their bedchamber. The frequent contact with the image engendered a deep sense of intimacy. This intimacy was helped by the compositions' usual half-length format, the naturalism, and the affecting quality of the subjects' expressions.

In the sixteenth century, theorist Giovanni Battista Armenini wrote about Italian paintings' ability to summon emotions: "So vivid and excellent were Correggio's, Titian's, and Giulio Romano's paintings, that the mysteries of Our Lord and the Blessed Virgin depicted in them inspired tenderness and even caused tears to flow from those who saw them."239 A close examination of a devotional Madonna painted by one of the masters Armenini praised will help to reveal how these images were received by supplicants. Correggio's devotional painting Madonna and Child with an Angel (ca.1525) in the Museum of Fine Arts, Budapest would certainly inspire tenderness in devotees, as Armenini projected (fig. 2.12). Here is a mother engaged in the everyday maternal deed of nursing her baby. It appears she is in the middle of the feeding when her wriggling baby becomes distracted by his companion, an angel offering fruit. The Christ Child's legs are splayed in his effort to turn around, creating a dynamic, diagonal composition. Correggio's use of the Christ Child's lively pose vividly contrasts with

(New Haven: Yale University Press, 1989), 23. Bernardo Daddi (1280-1348) became a skilled master in a fourteenth-century Florentine workshop that specialized in private devotional images. Henk van Os, The Art of Devotion, 21. In Siena, large numbers of surviving "stylistically homogenous" paintings for private devotion attest to workshops for production of devotional art. At least twenty small Madonnas are thought to be from Andrea di Bartolo's fifteenth century workshop. van Os, Art of Devotion, 74.

239"Ho veduto onorattissimi quadri, che vengono da Tiziano, dal Correggio, e da Giulio Romano, con dentro misterj [sic] di nostro Signore e della Beata Vergine, i quali, quando le matrone di chi erano vedevano scoperti per tenerezza usciano loro le lagrime dagli occhi, tanta era la vivacita e l'eccellenza grande di quelle." Giovanni Battista Armenini, "Dei Veri Precetti della Pittura, Libro Terzo," in Collezione di ottimi scrittori italiani in supplemento ai classico milanesi,(1587) (Pisa: N. Capurro, 1818), 211. 
Mary's tranquil demeanor. Her expression is full of motherly tenderness. She waits good-naturedly while the cherub and the Christ Child pause to play. The message here seems to be that Mary never loses her patience in the struggle even as Jesus squirms about. The open composition invites the viewer into the space and those who meditated before the scene surely sensed the Virgin's peaceful and happily obliging bearing. Correggio himself was a father of young ones at the time this was painted and undoubtedly witnessed how easily one could lose patience in frustrated attempts at small tasks. ${ }^{240}$ Yet, Correggio's biographers have little to go on when assessing the artist's demeanor. Vasari was his first biographer, and despite the fact that there is no evidence that Vasari ever spoke to anyone who knew Correggio and there are no surviving letters written by the artist, Vasari concluded that Correggio was "oppressed by his grasping family and melancholy." ${ }^{241}$ Documents about Correggio's artistic activity, certificates of his marriage, his children's births and baptisms, etc. have been published, but a sense of his temperament is absent from the written record. In the face of this lack of evidence, David Ekserdjian asserted, "To deduce a character from his oeuvre would be foolhardy, but [one] would be more likely to deduce joy than Vasari's melancholy from the smiling faces that populate his pictures. ${ }^{242}$ While the artist's personality remains an enigma, a sense of joy, or I would suggest, contentment does permeate his Madonnas. We have read how period writer Armenini reacted to his work. He recorded the reaction of viewers as one of tenderness. We noted contemporary biographer Ekserdjian perceived

\footnotetext{
${ }^{240}$ His first child, a son, Pomponio, was born 3 September 1521 in the town of Correggio. Cecil Gould, The Paintings of Correggio (Ithaca: Cornell University Press, 1976), 28 and 189, doc. X.; David Ekserdjian, Correggio (New Haven \& London, Yale University Press, 1997), 2 and 146.

${ }^{241}$ Quoted in Ekserdjian, 1. Ekserdjian consulted Vasari-Milanesi 1878 - 85: GiorgioVasari, Le Opere di Giorgio Vasari con nuovo annotazioni e commenti di Gaetano Milanesi, 8 vols and index (Florence: 1878$85)$.

${ }^{242}$ Ekserdjian, 1.
} 
joy because of the ever present smiling faces in Correggio's paintings. For purposes of discerning how the devotional painting Madonna and Child with an Angel was received, it can be said that supplicants certainly encountered a tenderly loving, serene mother unperturbed by her rambunctious baby. The familiarity of the scene would have struck the viewer, and such familiarity invited intimacy. They saw a woman who was able to transcend life's mundane frustrations and rise to a level of tranquility. As they recited their prayers, Mary's serenity was likely contagious.

There is scant evidence concerning the specific ways in which these private devotional images served the needs of devout lay persons. However, if we examine household inventories and private prayer books and look at period images of domestic interiors as well as the images themselves, an assessment of viewers' reception of Madonna and Child devotional images emerges.

Personal household inventories list the images in the dry language of such documents. The Madonna and Child image is often the first item listed, indicating its prominence in the scheme of personal possessions. ${ }^{243}$ The very personal nature of the practices performed before these images can be traced to their location within the home. Although they were hung in nearly every room, the bedchamber appears to be the most common place in the house for placing devotional images of the Virgin. Records show that at the time of marriage and the establishment of the household, young Florentine men focused foremost upon purchasing bedroom furnishings and listed among expenditures for beds and cassoni (marriage chests) were images of the Virgin and the

${ }^{243}$ Ronda Kasl, "Holy Households: Art and Devotion in Renaissance Venice," Giovanni Bellini and the Art of Devotion, Ronda Kasl, ed. (Indianapolis: Indianapolis Museum of Art, 2004), 64. Owning multiple Madonna images was not unusual in Renaissance household inventories. See John Kent Lydecker, The Domestic Setting of the Arts in Renaissance Florence (Ph.D. diss., The Johns Hopkins University, 1987), $145-183$. 
frames or tabernacle frames enclosing them. ${ }^{244}$ Medicean inventories of their familial belongings provide much evidence of Marian devotion. A single 1417 Medicean household inventory lists five paintings and one sculpture of the Madonna and Child, most of which were set in tabernacles in bedrooms as devotional aids to prayer. ${ }^{245}$ Hanging above the bed in the Venetian artist Vittore Carpaccio's Scenes from the Life of St. Ursula is an example of one such devotional painting (fig. 2.9 and 2.10). Less obvious is the profile of a small tabernacle frame in another Carpaccio painting. This one is fitted with a candelabrum and an aspergillum, for sprinkling holy water (fig. 2.11). A certain Lorenzo Morelli's 1469 account book lists the expense of fabricating such a tabernacle for his bedchamber. ${ }^{246}$ The candelabrum likely served to illuminate the painting, much as a spotlight or picture light would today, but when considered with the holy water receptacle and wand for sprinkling, candles also served a ritual or votive purpose. Votive candles were, and still are, used to signify the presence of holiness. ${ }^{247}$ The image, its tabernacle frame, the holy water situlae, and votive candles reminded homeowners of the sanctity of the bedchamber. San Bernardino's firm warning to women about exercising discretion before bedroom images of the Virgin underscored the sacredness of the space and reinforced the fact that devotional images of the Virgin were

\footnotetext{
${ }^{244}$ Kasl, 64; Richard Goldthwaite, Wealth and the Demand for Art in Italy 1300 - 1600 (Baltimore: Johns Hopkins University Press, 1993), 227-30; Lydecker, 99, 105, and 117.

${ }^{245}$ Christopher B. Fulton, An Earthly Paradise: The Medici, their Collections and the Foundations of Modern Art (Florence: Leo S. Olschki, 2006), 173. Fulton also referred to a 1492 inventory, which lists fourteen more images of the Virgin at their urban palace alone and many more distributed through Medici family rural villas. Because of the placement of multiple religious works in one room and the collection of rare and precious secular artworks stored with religious pieces, Fulton concluded the purpose of the sacred art was not always to inspire devotion. Admiration for artistic qualities and materials was also apparent.

${ }^{246}$ From an account book titled Spese di piu chose di Lorenzo Morelli entry of 2 February, 1469. See Lydecker,117.

${ }^{247}$ From the "General Instruction of the Roman Missal," under "The Place for the Reservation of the Most Holy Eucharist," the instruction reads: 316 . "In accordance with traditional custom, near the tabernacle a special lamp, fueled by oil or wax, should be kept alight to indicate and honor the presence of Christ." http://www.catholicdoors.com/faq/qu181/.htm, September 12, 2011.
} 
ubiquitous in the bedchamber. He specified that women should not appear before the images shamelessly dressed, and cosmetic jars or ampoules should not be placed all around the figure. ${ }^{248}$ That the devotional image was so often found in the bedchamber indicates that privacy - seclusion for personal prayer - was the objective. The ritual performed in this private, sacred space included prayers said by the supplicant but usually written by someone else.

When devotees knelt before their bedroom image, their prayers were either read or came from memory. There are examples that survive from the Renaissance period of tabernacle frames with inscribed prayers surrounding the image. For example, included among other prayers inscribed on a Tuscan tabernacle frame dating from ca.1460 - 80, the opening words of the Hail Mary, "Ave Regina Caelorum" (Hail, Queen of Heaven), are visible. ${ }^{249}$ Additionally, prayer books were used for devotion. The Officium Beatae Mariae Virginis was a popular prayer book among clergy and the laity, and it was especially recommended by spiritual advisors to women and girls. ${ }^{250}$ It was the most widely owned book of the period ${ }^{251}$ and the first Italian printing, a Roman edition, appeared ca. 1473 . By the end of the century twenty-six more editions were printed. ${ }^{252}$ The format stayed very much the same in the sixteenth-century when the number of printings more than doubled. Heavily illustrated books indicated popular readership. ${ }^{253}$ For individuals who were unable to read, prayers were committed to memory, having

\footnotetext{
${ }^{248}$ Bernardino da Siena, Le Prediche volgare, V, 206f. Quoted in Trexler,Public Life, 69.

${ }^{249}$ Timothy J. Newbery, George Bisacca and Laurence B. Kanter, Italian Renaissance Frames (New York: Metropolitan Museum of Art, 1990), 39.

${ }^{250}$ Paul Grendler, "Form and Function in Italian Renaissance Popular Books," Renaissance Quarterly, 46 no. 3 (Autumn 1993): 468.

${ }^{251}$ Kasl, 71.

${ }^{252}$ Grendler, 468.

${ }^{253}$ Grendler, 469-70.
} 
been passed down from generation to generation orally. Veneration, asking for an

advocate, imploring Mary to bestow mercy and thanksgiving, were intended goals. The medieval Salve Regina was one such prayer:

Hail, Holy Queen, Mother of Mercy;

Our life, our sweetness, and our hope!

To thee do we cry, poor banished children of Eve;

To thee do we send up our sighs,

Mourning and weeping in this valley of tears.

Turn then, most gracious advocate,

Thine eyes of mercy toward us,

And after this our exile, show unto us

the blessed fruit of thy womb, Jesus.

$\mathrm{O}$ clement, O loving, O sweet Virgin Mary. ${ }^{254}$

One of the best known Marian prayers of the period was the aforementioned Hail Mary, which became the mainstay of the rosary and the Angelus. The latter called for a series of three Hail Marys and a few other short prayers. These were said when bells rang three times a day, at six in the morning, noon, and six in the evening. The practice of reciting the rosary began to flourish among all classes at the end of the fifteenth century and into the sixteenth century. ${ }^{255}$ Its devotion was simple, inexpensive, and accessible to all.

Both the rosary and the Angelus were probably prayed before private devotional images. In the early fourteenth century popes began to make the repeated recitation of the Hail Mary a condition for granting indulgences, as recompense for time subtracted

\footnotetext{
${ }^{254}$ For a history of the origins of and legends about this medieval prayer visit http://newadvent.org/cathen/13409a.htm.

$\frac{}{255}$ Although there are many legends and stories about the origin of the rosary, scholarly consensus is that the rosary evolved over a long period and from multiple sources. The Dominicans embraced the devotion and the first rosary confraternity was established by Dominican friar Alain de la Roche (or Alanus de Rupe) in 1468-70. John D. Miller, Beads and Prayers: The Rosary in History and Devotion (London and New York: Burns \& Oates, 2002), 2, 11. Alanus wanted the confraternity to be easy to join. There were no constraints, dues, or vows attached. He wrote that that there should be no regulations for how the rosary was said or penalties for failing to say it at all. Anne Winston-Allen, Stories of the Rose: The Making of the Rosary in the Middle Ages (University Park, PA: Pennsylvania State University Press, 1997), 24 - 25.
} 
from one's Purgatorial term. ${ }^{256}$ Indulgence promises continued late in the fifteenth century under Pope Sixtus IV, who encouraged prayer before images as a way to earn a more rapid path to salvation. In several late fifteenth- and early sixteenth-century prayer books, devotees were encouraged to pray coram imagine Virginis Mariae in Sole. ${ }^{257}$ The words are attributed to Sixtus IV. Reducing time in Purgatory was a big incentive to pray before one's images. Devotional images were a means to a desired end.

While it is impossible to know how every Italian Renaissance person approached private devotion, there is evidence that they were told to recite prayers while they gazed at images. Devotees thus "spoke" to them. These images were most often hanging in the seclusion of the bedchamber. They are small, intimate, naturalistic, and became familiar through repeated viewings and because the subject matter had real-life resonance. Additionally, such images were thought to be powerful conduits to the divine. They were themselves sacred artifacts through which one could pray effectively for favors, mercy, and, above all, salvation.

\section{Plaquettes and Paxes}

Our final example of private Marian devotion is the use of an image that belongs to a group of mass-produced bronze relief sculptures meant for the taste and pocketbook of the growing middle class in Renaissance Italy. Included in this category is the liturgical pax, a metal relief - usually of the Virgin Mary - which was used as an object of devotion to be kissed during late medieval and Renaissance liturgies. ${ }^{258}$ We will

\footnotetext{
${ }^{256}$ van Os, Art of Devotion, 60.

257 "Their image of the Virgin Mary in the Sun." The Virgin of the Sun is linked to versions of prayer to the Virgin Immaculate, and Sixtus IV was a supporter of the highly controversial Immaculate Conception doctrine at the end of the fifteenth century. Sixten Ringbom, Icon to Narrative: The Dramatic Close-up in Fifteenth Century Devotional Painting, second ed. (The Netherlands: Davaco Publishers, 1984), 26.

${ }^{258}$ Andrew Meehan, "Pax," The Catholic Encyclopedia, vol. 11 (New York: Robert Appleton Company, 1911), http://www.newadvent.org/cathen/11594b.htm.
} 
return to paxes presently. According to Allison Palmer, countless variations of the Madonna and Child motif survive in plaquettes made of bronze, silver, and (more rarely,) gold. ${ }^{259}$ The vast numbers attest to their popular appeal within a market typically unable to afford one-of-a-kind devotional artworks. These plaquettes were not commissioned, like other devotional images we have studied, and their mass-production speaks of consumer demand. So if they were in such high demand, how did people wish to make use of them? Because problems concerning attribution, dating, and stylistic trends of these plaquettes were initially the center of scholars' attention, the function of the plaquette had not been addressed until the late 1980s. ${ }^{260}$ Palmer studied a high quality example owned by the Walters Art Museum, which is traditionally attributed to Donatello and dated to the 1440 s (fig. 2.15). ${ }^{261}$ It is small (3 3/4" x 2 15/16") and can easily fit in the palm of one's hand or in a pocket. Palmer hypothesized it functioned as a devotional image because of three factors. First, the subject indicates a devotional purpose: the image is a religious icon depicting the Virgin and Child in a warm embrace. Second, there are three small holes - one on top and two at each bottom corner indicating it was made to hang, possibly by a bedside or inside a bed curtain at some time. Lastly, the plaquette reveals smooth corners and signs of wear, suggesting frequent rubbing, possibly while inside the owner's pocket. ${ }^{262}$

\footnotetext{
${ }^{259}$ Allison Lee Palmer, "The Walters' Madonna and Child Plaquette and Private Devotional Art in Early Renaissance Italy," The Journal of the Walters Art Museum, 59 (2001): 73 and 75.

${ }^{260}$ For a full study of the context and function of fifteenth-century Italian plaquettes see Alison Luchs, ed., Italian Plaquettes, vol. 22, Studies in the History of Art (Washington D.C.: National Gallery of Art, 1989). Especially see essays in that volume by John Pope-Hennessy "The Study of Italian Plaquettes," and Christopher B. Fulton, "The Master of IO F.F. and the Function of Plaquettes." Most of the examples they studied depicted secular subjects. Palmer's research about the function of plaquettes portraying religious subjects added to the scholarship addressing the plaquettes' purpose.

${ }^{261}$ Palmer, 73. The plaquettes are undated, unsigned and their provenance is unknown, making certain attribution and dating problematic.

${ }^{262}$ Palmer, 73.
} 
Palmer focused upon its devotional function in the bedroom. She hypothesized that the subject of the plaquette reflected Tuscan spiritual and familial authority and ideas about family solidarity. ${ }^{263}$ She demonstrated that family values were expressed in Marian plaquettes and in family documentation, where explanations about virtuous qualities in a good wife were recorded. As an example, Palmer offered a passage from Alberti's The Family in Renaissance Florence in which Giannozzo Alberti and his new wife knelt before a small statuette in the bedroom where they prayed. "We also prayed with most devoted mind that [God] might grant us the grace to live together in peace and harmony for many happy years. ${ }^{264}$ Then Giannozzo delivered a speech to his bride about the evils of wearing make-up in order to avoid the appearance of being less virtuous than she really was. He cautioned, "Shun every sort of dishonor, my dear wife. Use every means to appear to all people as a highly respectable woman.,265

While it is conceivable that the plaquette hung in a bedchamber for devotional use, it is not certain. We have already established the use of devotional images in that private space. But while I do not argue against its use in bedrooms, in this case we do have material evidence that the image had been rubbed repeatedly. ${ }^{266}$ The surface is worn. Consequently it is the probable use of the image while held or pocketed that I find most intriguing. It implies a truly private form of devotion, one in which a person would engage alone. One fascinating aspect of this practice is that the artwork itself provides clues about its function. The worn places on the plaquettes indicate the devotional

\footnotetext{
${ }^{263}$ Palmer, 73.

${ }^{264}$ Palmer, 78. See Leon Battista Alberti, The Family in Renaissance Florence, (Libri della famiglia) trans. Renee Neu Watkins (Columbia SC: University of South Carolina Press, 1969), 212.

${ }^{265}$ Alberti, 213.

${ }^{266}$ Additionally, as William Levin pointed out to me, the three holes may have been bored into the plaquette centuries later.
} 
method. The evidence of it is not recorded in a text or diary; it was unremarkable to participants. As with devotion before roadside shrines, the ordinariness of the activity leaves historians without written record, mirroring the devotional activity of rubbing the medals on a rosary in one's pocket as people pray - an everyday activity in which supplicants have engaged for generations, yet again one which has gone unrecorded.

Other examples of rubbing a sacred object during prayer are recorded, too. For instance, half-way up the right aisle in Saint Peter's Basilica in Vatican City is a bronze sculpture of St. Peter, usually attributed to Arnolfo di Cambio. Praying pilgrims have rubbed the right foot of the bronze for centuries, eventually obliterating its toes (figs. 2.16 and 2.17). ${ }^{267}$ People may have used the plaquette in the same way, as a talisman, rubbing it for comfort or to release its magic. I would like to suggest that rubbing the icon was a sensory action that complemented people's devotional prayers in the same way that supplicants engaged their eyesight with the image, to enhance contemplative meditation. Chapter three will demonstrate how smelling burning incense, hearing bells, and eating were also employed during devotional activity. All five sensory activities aided devotion. Engaging the senses during prayer intensified the experience.

The very private nature of such "pocket devotional activity" is the antithesis of the rituals surrounding Our Lady of Impruneta, which required a procession, or the horsedung-inspired Madonna de' Ricci, which required the building of a new, larger church to accommodate its growing cult. However the private nature of the devotional artwork is

\footnotetext{
${ }^{267}$ Saint Peter's Basilica.Org "Statue of St. Peter," http://saintpetersbasilica.org/Statues/StPeter/StPeter.htm. There are travel blogs available for further reading on this subject. Some tourists report their motive for standing in line to kiss or rub the famous foot. For further reading on this see a host of travel blogs offered by Googling, "Rubbing St. Peter's foot." Thanks to the pervasiveness of electronic media, future historians will have the benefit of blogs and other forms of social media for records of the mundane activities.
} 
no less significant to the study of social history. If we can contextualize the most ordinary activities of citizens, we will have a more finely-tuned glimpse into the past. When considering the function of these small objects John Pope-Hennessy wrote, "They [the plaquettes] were, after all, not just works of art, but part of the infrastructure of Renaissance life." ${ }^{268}$ Although the smallest of devotional images we have examined, their significance should not be understated.

Palmer pointed to Mary's warm maternal embrace of Christ, so apparent in the Walters plaquette, as a signifier for hope for family harmony in Renaissance Tuscany. She used San Bernardino of Siena's sermons ${ }^{269}$ and Alberti's writings on the family to support her argument. Their texts entreat people to avoid family conflict and to uphold peace in the family unit. We have seen the same authors (and many others) advocate maternal nursing. The Madonna lactans motif on a plaquette of a nearly identical size as the Palmer example would serve a purpose similar to the one the scholar suggested (fig. 2.14). ${ }^{270}$ It is round and measures $215 / 16$ inches in diameter and would have fit nicely in someone's hand or pocket. There is a loop at the top for hanging, also. If we apply Palmer's consideration of subject, holes for hanging, and wear, the privately owned object pictured, too, was likely used for devotion and was demonstrative of a cherished family value. In our example, the Virgin leans in closely, staring directly into her Son's eyes, and he into hers. The connection established by the intimate body language reflects the maternal bond of love championed by moralists of the period. Recall that Matteo

\footnotetext{
${ }^{268}$ John Pope-Hennessy, "The Study of Italian Plaquettes," in Italian Plaquettes, 30.

${ }^{269}$ Palmer, 78. See David Herlihy, "Santa Caterina and San Bernardino: Their Teachings on the Family," reprinted in Women, Family and Society in Medieval Europe: Historical Essays 1978 - 1991 (Providence: Berghahn Books, 1995), 189.

${ }^{270}$ This example is in a private collection. Victor Lasareff mentioned a Roman Virgin lactans plaquette from the thirteenth century in the Kaiser Friedrich Museum (now called the Bode Museum) in Berlin. Lasaerff, 34.
} 
Palmieri counseled in favor of maternal feeding, saying that the natural bond and maternal love would be lacking in children fed by a hired nurse. "Then it happens that when children [who had been given to a wet nurse] are grown, they do not have in the mother a love that is bound by constant affection. ..."271 The patina on the surface of our example shows wear - evidence that the plaquette may have been rubbed during prayer. The figure composition is a remarkably close descendant of Andrea Solario's Madonna with the Green Cushion (fig. 4.2), which was painted either in France between 1507 and 1510 while the artist was in the service of Georges d'Amboise, or upon Solario's return to the duchy of Milan while painting for Charles II d'Amboise soon after the artist's return. ${ }^{272}$ Nothing is known about the fabrication or provenance of this plaquette. The artist faithfully replicated Solario's figures' poses and their attitudes, though Solario's landscape in the background is absent in the bronze. Plaquette designers frequently borrowed compositions from masters, and the concept of having exclusive rights to a work of art was almost unheard of in the quattrocento. In fact designers were generally itinerant, undocumented craftsman who worked from copies and casts. ${ }^{273}$

In addition to being an example of desired behavior, the nursing Madonna plaquette may have been deployed to promote abundant milk as devotees surreptitiously rubbed its surface in daily prayer. A wet nurse or her husband might have used the plaquette in this way to ensure employment, for it was the type of devotional art they could manage to purchase. A nursing mother or her husband may have prayed for their child's nourishment in this manner as well. The personal aspect of the way the plaquette

\footnotetext{
${ }^{271}$ Matteo Palmieri, 10. My gratitude for Msgr.William F. Cleves's help with the translation.

${ }^{272}$ Cécile Scailliérez, "Madonna of the Green Cushion," Musée du Louvre, http://www.louvre.fr/en/oeuvrenotices/madonna-green-cushion.

${ }^{273}$ Palmer, 74.
} 
was used for prayer is unlike any of the other private devotional activities that we have examined. It lacks any hint of theatrics or susceptibility to chance voyeurism. It is completely unselfconscious. It engages the sense of touch and the friction imposed by the supplicant changed the surface of the artwork.

The liturgical pax was rubbed and kissed too, but that is where the similarities in devotional use of plaquettes and paxes part ways (figs. $2.17-2.19$ ). ${ }^{274}$ The smaller paxes were usually fixed to a metal handle to be carried in a procession and held in place while churchgoers processed up to kiss or rub it during the celebration of the Mass. Use of paxes during Mass was widespread in fifteenth-century Italy. Although the liturgical pax and its cousin, the plaquette, are quite similar in material and design, there is a distinction in the public and private nature of their devotional use. When the pax was carried in a procession and kissed in the public venue of a Mass, it resembled the much larger processional activity connected to Our Lady of Impruneta. Trexler deduced from historical records that because no miracles were ascribed to the Impruneta image in situ, "It was the procession, in motion, and not in any enclosed sacred place that [Our Lady] performed.” Of Our Lady of Impruneta a 1372 chronicler said, “This blessed tavola made many miracles in coming and leaving." ${ }^{275}$ It seems people believed, at least of the Impruneta image, that movement stimulated miraculous power. Processions in liturgical settings were elaborate affairs in the Renaissance world. The priest carried the sacred object and attendants censed the area in front and behind. It is curious that two such

\footnotetext{
${ }^{274}$ I am grateful to Christopher Fulton for making me aware of these little-studied objects. Artists reissued them without handles and the converted paxes were prized collectables. They could fit into a collector's drawer or cabinet. The small bronze plaquettes were also adorned with mythological and other secular subjects. See Victoria and Albert Museum, http://collections.vam.ac.uk/item/O248710/the-virgin-andchild-with-plaquette-moderno/.

${ }^{275}$ Quoted in Trexler, Public Life, 63 from Cronichette Antiche ..., 199.
} 
similar devotional objects, such as our plaquette and pax, were used in such different ways. The plaquette was an object of intensely private devotion and the pax, at least in its liturgical setting, was used for the public display of piety. Veronese plaquette designer Moderno is said to have been the most accomplished designer of plaquettes and paxes in Renaissance Italy. ${ }^{276}$ In both examples of Moderno's paxes the Madonnas are nursing within architectural frameworks (figs. 2.17 and 2.18). They resemble tiny altarpieces, highlighting their liturgical application. The pax attributed to Donatello, or a member of his circle is a much more intimate view, bringing the viewer close to the picture plane, and the breastfeeding aspect is anything but subtle (fig.2.19). The artist developed the nursing breast explicitly, clearly designating the Virgin as the Christ Child's nurturer. The close-up viewpoint resembles that of a small devotional painting of the period, like Madonna and Child with an Angel by Correggio (fig. 2.12) or the plaquette in the private collection (2.14). It reflects the endorsement of maternal feeding, capturing the Virgin and Child engaged in a tender moment. The Virgin looks with love at her baby while he caresses her. Moderno's compositions take a longer view, distancing the devotee from the intimacy of the scene. It is tempting to ascribe a liturgical use to Moderno's two paxes with their altarpiece-like architectural settings, and a private devotional use to the Donatello piece.

Marian devotion in late medieval and Renaissance Italy manifested itself publicly during processional ceremonies as an image was paraded through the streets or enshrined at the locus of a perceived miracle. In private, individuals prayed before street corner images, or small tabernacle images in their bedrooms, or with a hand-held image tucked neatly in their side pockets. Italians were not concerned with the high or low quality of

276“"Moderno Biography (1467 - 1528)," ArtFact, http://www.artfact.com/artist/moderno-fi9sof7ned\#top. 
the image; rather they relied on the image's facility to be a potent catalyst for a connection to the divine.

The Virgin was portrayed in roles ranging from intercessor to ordinary mother, such as in books describing her daily care of the Christ Child and in paintings of her patiently waiting to nurse her wriggling baby. People flocked to the roadside tabernacle Madonna lactans image, praying for abundant milk or fertility. They prayed, paid homage, and gave thanks with votive offerings during public festivals and in their private bedrooms, or they rubbed their hand-held icons in private prayer. Popular Marian devotion in late medieval and Renaissance Italy continued to hinge on the intercessory role Mary played. When people prayed before the image of Mary, they were appealing to her for favors, or giving thanks for favors already rendered, as they had since before Theophilus and continue to do so today, visiting milk shrines, and ingesting "milk powder." Their preoccupation with her had everything to do with their need for a Mother-Intercessor. People wanted someone to listen to and care for them.

Our investigation of how people perceived the Virgin Mary in late medieval and Renaissance Italy is vital to appreciating how individuals interacted with the Madonna lactans image. Saint Bernard's poetry about Mary’s powerful milk might have been one garden in which the budding zeal for the image took root. We have observed that people practiced devotion to Mary through contemplative prayer aided by period texts. Engaging in spiritual exercises was essential to worshipers' interaction with the Virgin, and the Madonna lactans in particular. Seeing the Virgin in a variety of roles opens us to multiple readings of the Madonna lactans. We will see that given the context, the nursing Madonna was intercessor, comforter, healer, and a channel to communion with 
God. She was perceived as accessible to her faithful followers in great crowds and in the solitude of their innermost thoughts. 


\section{CHAPTER III}

\section{SUSTENANCE FOR LIFE: THE MADONNA LACTANS AND SACRAMENTAL WORSHIP IN LATE MEDIEVAL ITALY}

The image of the Virgin Mary nursing the Christ Child has roots in antiquity, early Christian, Byzantine, and Egyptian Coptic art, but at the end of the thirteenth century and the beginning of the fourteenth century the image emerged in significant numbers in the West and became increasingly popular in Italian altarpieces. Margaret Miles posited that it was malnutrition and epidemic disease that led hungry fourteenthcentury Italians to value an image of the Virgin feeding her son. ${ }^{277}$ But this chapter proposes another interpretation. A spiritual hunger caused by a decree of the Fourth Lateran Council which led to infrequent reception of the Eucharist may explain the image's prevalence in late medieval altarpieces. The fourteenth-century Madonna lactans motif in altarpieces satiated churchgoers' spiritual hunger engendered by the practice of receiving Communion only very infrequently. The result was that medieval worshipers engaged in the practice of spiritual communion. This ignited the spiritual senses, and medieval worshipers seeking communion with Christ were fed - experienced

\footnotetext{
${ }^{277}$ Margaret R. Miles, "The Virgin's One Bare Breast" in The Secularization of the Breast (Berkeley and Los Angeles: University of California Press, 2008), 33.
} 
sustenance - through the symbolic nursing Madonna image. Viewed through the "period eye," it likely was perceived as a sacramental, the impact of which provided all the potency and efficacy of the Eucharist itself.

In 1215 the council decreed unambiguously that Christ was present in the Eucharist as flesh and blood. Christ's "real presence" under the appearance of bread and wine was affirmed. The canon stated:

In [the Church] there is ... Jesus Christ, whose body and blood are truly contained in the sacrament of the altar under the forms of bread and wine; the bread being changed by divine power into the body, and the wine into the blood, so that ... we may receive of Him what He has received of us. ${ }^{278}$

The decree resulted in a new attitude toward the Eucharist; it became more precious, reception of the sacrament became infrequent, devotion deepened, and a practice known as spiritual communion was initiated. Mass became increasingly theatrical, and new liturgical rituals like the Elevation of the Host during the consecration generated the need for a visual signifier - a motif befitting the momentous ritual. The painted altarpiece was introduced as a backdrop for the Mass where the faithful's attention could be centrally focused. Marian images were favored for these altarpieces, ${ }^{279}$ and, as noted the motif of Mary nursing her Son enjoyed a surge in popularity in fourteenth-century Italy. By taking into account medieval peoples' penchant for relics, their understanding of the power of seeing and their grasp of physiological matters, and by examining textual evidence available to medieval people, we will endeavor to deduce what this image, located above the altar, meant to them. This chapter proposes that the altarpiece image of

\footnotetext{
${ }^{278}$ Quoted in Mary C. Moorman, "A Theological Reading of Medieval Vessels as Emblems of Embrace," in Perspectives on Medieval Art, Learning through Looking, ed. Ena Giuescu Heller and Patricia C. Pongracz ( New York: Museum of Biblical Art, 2010), 160.

${ }^{279}$ Henk van Os, Sienese Altarpieces 1215 - 1460, vol. 1(Groningen: Bouma's Boekhuis bv, 1984), 12 15.
} 
the Madonna lactans, as a backdrop and physical framework for the Mass's climactic consecration of the Host, provided the faithful with a visual allusion to communion. ${ }^{280}$ Moreover, this analysis will explore the implications of a deeper meaning medieval people may have associated with this image - that the image served as a sacramental "an outward sign of an inward grace ...."281 For late medieval devotees the image possessed the impact and potency analogous to the Eucharist itself that was consecrated at the altar before it.

Medieval peoples' perceptions about images' properties may well have been influenced by the eucharistic doctrine in the Lateran decree. If simple substances like bread and wine could become the body and blood of Christ, then what might occur through a human likeness? A physical thing such as an image was poised for the same sort of transference in the Middle Ages. The notion was not a new one. Plotinus' philosophy was that the tendency to capture the presence of the divine in an image or object was part of our nature:

I think ... that those ancient sages who sought to secure the presence of divine beings by the erection of shrines and statues showed insight into the nature of the All; they perceived that, though this Soul (of the world) is everywhere tractable, its presence will be secured all the more readily when an appropriate receptacle is elaborated, a place especially capable of receiving some portion or phase of it, something reproducing it and serving like a mirror to catch an image of it. ${ }^{282}$

\footnotetext{
${ }^{280}$ See also Beth Williamson, "The Virgin Lactans and the Madonna of Humility in Italy, Metz and Avignon in the Thirteenth and Fourteenth Centuries" (Ph.D. diss., London University, 1996), $186 \mathrm{ff}$. Williamson wrote about some aspects of the Virgin lactans in the context of the history of the altarpiece. I am entering into the dialogue and am investigating additional points about the image, filling a void left by infrequent communion reception and its role as a sacramental.

281 "Peter Lombard (d. 1164), author of the manual of systematized theology, gave an accurate definition of the sacrament of the New Law. ..." See Nature of the Sacraments of the New Law, The Catholic Encyclopedia, http://www.newadvent.org/cathen/13295a.htm\#II.

${ }^{282}$ Plotinus, Ennead, IV, 3.11, quoted in Richard C. Trexler, Public Life, 56.
} 
Plotinus felt that connecting with the divine was most likely to occur if there was a receptacle (like an image that reflected a divine likeness) in which it could be secured. Historians agree that medieval people perceived and interacted with images very differently from our present-day approach, and that perception might have been tied to the burgeoning cult of the body of Christ. Hans Belting explained, "[An] image ... implies both appearance and presence." ${ }^{283} \mathrm{He}$ continued, "The beholder was in touch with the real presence in, and the healing power of, the image." 284 If one substitutes the last word in the previous sentence - image with Eucharist - Belting could have been a theologian speaking about the Eucharist in the Middle Ages. The medieval beholder was also very much in touch with the real presence and healing power of the consecrated bread and wine in the Eucharist. Belting may have inadvertently made a correlation between the beholder's interaction with an image and with the Eucharist, but Richard Trexler and Michael Camille were more deliberate when they drew the parallel. Trexler theoretically linked the two, asserting, "The cult of the body of Christ validated one of the strongest religious tendencies: to give form to power on the principle that power was imputable to objects." 285 And Camille clearly drew the parallel when he wrote, "The notion of the 'real presence' in eucharistic practice must have deeply influenced people's perception of images, for here a visual thing was itself capable of becoming and not just signifying its prototype."286 This study concurs with Plotinus and the three historians. Medieval perceptions about divine presence in objects and images are a chief

\footnotetext{
${ }^{283}$ Belting, 9 .

${ }^{284}$ Belting, 53. Belting used the phrase "real presence" to describe medieval people's understanding of an image's properties. The same terminology was used in the doctrinal explanation of Christ's essence in the Eucharistic bread and wine.

${ }^{285}$ Trexler, Public Life, 56.

${ }^{286}$ Camille, The Gothic Idol, 217.
} 
consideration when we ask: how were these perceptions processed when the congregation fixed their eyes upon the Madonna lactans image overlaid by the ceremony at the altar. But first let us consider devotion to the sacrament of the Eucharist in the Middle Ages.

\section{Late Medieval Devotion to the Eucharist}

A result of the 1215 declaration of Christ's real presence in the consecrated Host was a considerable increase in devotion. Medieval peoples' proclivity for relics in the preceding years now transferred to the Host. Fervent devotion to saints' sacred relics can be traced to the fourth century. ${ }^{287}$ Miracle-working relics became the centerpiece of ritual and pilgrimage during the medieval period. ${ }^{288}$ The closer a relic was related to the divine, the more worshipers treasured it. Because she was the Mother of God, believers desired any vestige of the Virgin, yet her corporeal relics - her body parts - were unattainable because Christians believed in the bodily assumption of the Virgin into Heaven. Hence, cults associated with her milk materialized, and vials of her milk became highly prized relics. As elaborated in the previous chapter, they were popularized by a story about the Virgin visiting the Cistercian monk, Bernard of Clairvaux, in which she offered him milk from her breast. As much as medieval people exalted the Mother of God, they revered God himself the most. It was a natural leap for

\footnotetext{
${ }^{287}$ Andre Vauchez, Sainthood in the Later Middle Ages, trans. Jean Birrell (Cambridge, UK: Cambridge University Press, 1997),16. In 383 CE St. Ambrose exhumed the remains of Saints Gervaise and Proteus in Milan. This find is thought to be the first relic exhumation and to have ignited the medieval cult of relics. The well-timed discovery came just before Empress Justina's attempt to expel Ambrose. At the crowded dedication of the basilica of Milan, Ambrose unearthed the bodies of the two martyrs, which were then ceremoniously gathered up by the crowds and venerated. The relics' discovery saved Ambrose, and scores of similar finds were subsequently recorded.

${ }^{288}$ Patrick Geary, Furta Sacra: Thefts of Relics in the Central Middle Ages (Princeton, N.J.: Princeton University Press, 1978), 40-50. The cult of relics was boosted considerably after 787 when the second council of Nicaea resolved that relics must be present at all church dedications. Geary proposed the veneration of relics was encouraged by Charlemagne and brought under his control in order to bolster his program of political, social and religious consolidation. See also Jonathan Sumption, Pilgrimage: An Image of Medieval Religion (Totowa, NJ: Roman and Littlefield, 1975), 29 - 30.
} 
people to embrace the Host as the holiest of all "relics" after the Lateran decree when devotion to the body of Christ in the Host reached unprecedented heights.

However, one expression of this newly ignited devotion took the opposite form one might expect. Frequency of receiving communion decreased rather than increased after 1215. Council theologians who addressed the criteria for worthiness feared frequent reception would breed familiarity with the sacrament, which would lead to indifference. ${ }^{289}$ Most synodal legislation recommended three communions a year - at Easter, Pentecost, and Christmas. ${ }^{290}$ Accordingly, the populace relied on spiritual communion, a practice in which seeing the host was tantamount to eating it. ${ }^{291}$ And so a new ceremony - the Elevation of the Host - was deliberately introduced into the Western liturgy, which became an increasingly theatrical experience. The priest held the consecrated Host aloft for several seconds so that the congregation could see it from wherever they sat. ${ }^{292}$ The congregation's ability to see the Host was, therefore, of utmost importance.

\section{Visibility}

Some historical background about visibility of the act of consecration in the liturgy will answer questions about the faithful's ability to see, and hence receive, the

\footnotetext{
${ }^{289}$ Gary Macy, The Theologies of the Eucharist in the Early Scholastic Period (New York: Oxford University Press, 1984), 89 - 90.

${ }^{290}$ Guillaume Durandus, Rationale divinorum officiorum IV (Belgium: Turnholti Brepols, 1995), 310. Miri Rubin, Corpus Christi: The Eucharist in Late Medieval Culture (Cambridge: Cambridge University Press, 1991), $64-70$.

${ }^{291}$ Rubin, Corpus Christi, 52, 63 and 150. Ann W. Astell, Eating Beauty: The Eucharist and the Spiritual Arts of the Middle Ages (Ithaca: Cornell University Press, 2006), 3. Margaret R. Miles, Image as Insight, 96 $-97$.

${ }^{292}$ Gerald G. Grant, S.J., "The Elevation of the Host: A Reaction to Twelfth Century Heresy,” Theological Studies, I (1940): 229 - 230.
} 
Blessed Sacrament. ${ }^{293}$ The congregation's non-obstructed view of the altar is of interest to this study, because a view of it and the altarpiece behind it is an essential consideration. If churchgoers could not see the image on the altarpiece, then we have no foundation for saying that they perceived a eucharistic connotation in the nursing Madonna, that it satiated spiritual hunger, or that the image itself had a sacramental function. In fact, a barrier between the sanctuary and the congregants has a long history.

In fourth-century Syrian churches a veil hid the sanctuary, which kept the laity and clergy quite separate. Gregory Dix's explanation of the custom makes a distinction between the Eastern and the Western rites. An atmosphere of mystery and awe surrounded the 'terrifying' power of the eucharistic sacrament in Eastern churches. Wooden and/or metal screens were introduced in sixth-century Constantinople, again creating a barrier between the congregation and the liturgical action. ${ }^{294}$ However, according to Dix, the West exhibited a preference for showing the consecration rite to its laity. Such was the nature of Western devotion. Screens were introduced in the West but Dix asserted they were used as protection against draughts in convent and collegiate churches, not as visual obstructions. He differentiated between the Eastern and Western traditions: "The Eastern screen was meant to shut the congregation out, the Western one was meant to shut them in."295 Marcia Hall conducted a study of Italian rood screens, making the subject a bit ambiguous, however. ${ }^{296}$ Her work examined the pre-Tridentine presence of a large, conspicuous, view-obstructing structure in a major Italian conventual church. The ponte in the Dominican church Santa Maria Novella in Florence, highlighted

\footnotetext{
${ }^{293}$ See also Williamson, "Virgin Lactans," $210-214$.

${ }^{294}$ Gregory Dix, The Shape of the Liturgy (London: A. \& C. Black, Ltd. Dacre Press, 1945), 480 - 81.

${ }^{295}$ Dix, 482 n. 1.

${ }^{296}$ Marcia B. Hall, "The Ponte in S. Maria Novella: The Problem of the Rood Screen in Italy," Journal of the Warburg and Courtauld Institutes 37 (1974): 157 - 173.
} 
in her article, would have absolutely obscured the laity's view of the altar. Hall maintained that screens like Santa Maria Novella's and others' were removed in the last half of the sixteenth century. The Council of Trent endeavored to correct the isolation of the laity from the liturgy, prompting an architectural purge of the offending obstructions. ${ }^{297}$ The author acknowledged that not all churches and cathedrals had the screens, however. For example she concluded that there is no evidence to suggest that the major Tuscan cathedrals ever had an architectural obstruction like Santa Maria Novella's. The great Gothic cathedrals in Florence, Siena, Pisa and Orvieto never had large barriers. In the Duomo in Florence, for example, she allowed that the only obstruction was a "rather low wall" around the sanctuary and choir. Evidently Italy was home to churches and cathedrals in which rood screens were both absent and present. Dix acknowledged the existence of these screens, even as he wrote about them being removed or pierced. In sum, the evidence that the screens existed in some churches is indisputable. For our purposes, the larger question is, could congregations see the altarpiece and the Host being elevated?

\section{Liturgical Practices for the Elevation Rite}

Several other liturgical practices and the instructions for them, initiated around the time or some years after the Elevation rite was instated, tell us the goal was optimum viewing. It stands to reason these would not have been instituted if seeing the altar was an impossibility. In 1312, admonitions to avoid clouding the view of the Host

\footnotetext{
${ }^{297}$ Hall, 157 - 58. S. Carlo Borromeo wrote about facilitating the layman's involvement in Mass in his 1577 book on church architecture. Obviously removing obstructions would not have been addressed if it they were not impeding visibility in the first place.
} 
accompanied the new practice of censing the area around the elevation ritual. ${ }^{298}$

Additionally, the deacon or Mass-server lifted a consecration candle aloft at the climactic moment. Initially this took place only at early Mass, when it was still dark, "ut corpus Christi . . possit videri" - so the body of Christ could be seen. ${ }^{299}$ Where there were no altarpieces, dark curtains were drawn behind the altar in order to create a contrast for the white Host during the elevation. ${ }^{300}$ Sightlines to the altar must have been, in many cases, unobstructed.

Medieval writings about the solemn Elevation of the Host ritual verify its visibility, as do other accompanying ceremonies. William of Auxerre (d. 1230s) wrote about the ritual in his Summa de officiis. "[T]he priest elevates the Body of Christ in order that all the faithful may both see it and seek what is necessary for salvation." ${ }^{301}$ Priests taught that witnessing the elevation had the efficacy of a sacrament, and it would profoundly affect participants. ${ }^{302}$ Problems arose when people reverenced the host as soon as they could see it, before its transubstantiation. To obviate this impropriety, a French bishop instated the practice of holding the unconsecrated host breast-high before the consecration and only after the blessing would it be lifted high in the air for all to venerate and "receive." The two-tier elevation practice spread rapidly and various synods adopted it. A London synod of 1215 concluded with the statement: “. . . lest a

\footnotetext{
${ }^{298}$ The instructions are found in the Carmelite Ordinal of 1312. See Josef A. Jungmann, "The Consecration: The Accompanying Actions," in The Mass of the Roman Rite: Its Origins and Development (Missarum Solleninia), vol. 2, trans. Francis A. Brunner, (New York: Benziger Brothers, Inc., 1951 - 55), 209 n. 46.

${ }^{299}$ Records about lighting the candle before and extinguishing it after the elevation are numerous. The consecration candle turned into the Sanctus candle, an expression of reverence for the Blessed Sacrament. See Jungmann, vol. 2, 209 n. 45.

300 This occurred chiefly in England and France. Jungmann, vol. 2, 209.

${ }^{289}$ "Sacerdos elevat Corpus Christi ut omnes fideles videant et petant quod prosit ad salutem." Quoted in Macy, 188 n. 142.

${ }^{290}$ Rubin, Corpus Christi, 63.
} 
creature be adored, instead of the Creator.",303 The obvious difficulty in "seeing" the Precious Blood through an elevated chalice deemphasized the second elevation ritual. It was not until the second half of the sixteenth century that Pius V decreed that the second elevation of the chalice should follow the Host's elevation. To draw attention to the moment of transubstantiation other customs were added to the elevation ritual. Servers rang bells to alert the faithful of the momentous rite early in the thirteenth century, a practice still performed today in many churches. Initially one ring indicated the consecration moment, then anticipatory bell-ringing was added and eventually bells signaled the rite's closing. Further, large exterior church bells augmented the small interior bell-ringing in order to call attention to the moment of consecration for those busy in the field or at home. It was not unusual for people working outside to pause and turn toward the church to worship the Blessed Sacrament from where they stood. ${ }^{304}$ Hearing the bells prompted reverence. Thus the sacrament was tied to other senses as well, although the sense of sight was thought to be the most efficacious.

The laity greatly anticipated this part of the Mass. Daily Mass was available to all classes. Records tell of instances where people raced from church to church to see as many consecrations as possible. ${ }^{305}$ Devoted laymen were known to plead, "Heave it higher, Sir Priest!"306 The increasingly popular Madonna lactans provided the "scenery"

\footnotetext{
303 Jungmann, $206-207$.

${ }^{304}$ Jungmann, vol. 2, $209-210$.

${ }^{293}$ Peter Browe, Die Verehrung der Eucharistie im Mittelalter (Munich: M. Hueber, 1933), 68. Jungmann, vol. 1, 121. Caroline Walker Bynum, Holy Feast Holy Fast: The Religious Significance of Food to Medieval Women, (Berkeley and Los Angeles: University of California Press, 1987), 55. Williamson, "Virgin Lactans," 215 n.18.

${ }^{306}$ Dix, 14 and 620. Thomas Cranmer, The Remains of Thomas Cranmer, Archbishop of Canterbury, ed. Henry Jenkyns (Oxford: Oxford University Press, 1833), 442. Thomas Cranmer, Archbishop of Canterbury quoted medieval churchgoers as saying: "Hold up! Hold up!" and "This day I have seen my Maker" and "I cannot be quiet except I see my Maker once a day." Jungmann, vol.1,121 n. 101. Williamson, "Virgin Lactans," 215 n.19.
} 
for such theatrical actions. Viewing the consecration rite overlaid by the nursing motif connected the spiritually hungry congregation to the communion they could not ingest, hence fulfilling their desire for a closer co-mingling or union with God.

\section{Vision and the Spiritual Senses}

We know from many sources that medieval people thought that gazing at something - the act of seeing - represented a potent and powerful activity. Michael Camille argued that Gothic art is best understood through a concept of the eye as medieval people understood it - as "a powerful sense-organ of perception, knowledge, and pleasure." ${ }^{\prime 307}$ Audiences and artists of the era shared this way of seeing, known as "the period eye." Ancient theory of physical vision - a theory understood by medieval thinkers and embraced by medieval people - held that a quasi-physical ray was projected from the viewer's eye to touch the object, and an impression of that object traveled back along the ray making an imprint upon the viewer's soul. ${ }^{308}$ David Chidester summarized how ancient Greek philosophers explained optical theory. Although philosophers' theories differed in detail, they all relied upon a relationship between organ and object. In Platonic theory, Stoic theory, and among subsequent thinkers who derived their assumptions from them, vision required a "union between seer and seen."309 St. Augustine added to the theory about the "visual ray" connecting to the viewer's soul, asserting that a spiritual transformation occurred. ${ }^{310}$ Gazing at the Host involved coming

\footnotetext{
${ }^{307}$ Michael Camille, Gothic Art, 11.

${ }^{308}$ Miles, Image as Insight, 96. David Chidester, Word and Light: Seeing, Hearing, and Religious Discourse (Urbana and Chicago: University of Illinois Press, 1992), 3 - 6.

${ }^{309}$ Chidester, $3-6$.

${ }^{310}$ Xavier John Seubert, OFM, STD, "Liturgical Instruments and the Placing of Presence," in Perspectives on Medieval Art: Learning through Looking, ed. Ena Giurescu Heller and Patricia C. Pongracz (London: Museum of Biblical Art, 2010),141 - 43.
} 
into quasi-physical contact with it and spiritually transformed Mass-goers' souls. Miles explained, "By the vehicle of the visual ray, the object is not only 'touched' by the viewer, but the object is also 'printed' on the soul of the viewer." ${ }^{311}$ People of the time understood that the physical senses -- especially vision -- engaged the spiritual senses.

Origen of Alexandria's and St. Augustine's writings about the spiritual senses had a profound influence upon medieval thinkers. Later medieval doctrine of the spiritual senses is found first in William of Auxerre's Summa aurea, which defined these senses as "different modes of activity of the intellect, which completely envelops God."312 More than a perception of the physical world, the spiritual senses enabled mystical insight. Richard of Saint-Victor wrote about "corporal" and "spiritual" modes of vision with the fourth and deepest level involving "pure and naked seeing of divine reality."313 Medieval people satisfied their yearning to encounter the divine and their ardent desire to receive the transformed body of Christ by engaging in the practice of spiritual communion through the power of vision and the spiritual senses. The ritual of spiritual communion became central to medieval lay spirituality. In the thirteenth and fourteenth centuries, the Dominicans and Franciscans increased their efforts to teach visual meditative practices to the laity that, in effect, resulted in spiritual communion. Their focus was to engage them in meditative imagining, thus making Christ's real presence accessible to the laity and the

\footnotetext{
${ }^{311}$ Margaret Miles, Rereading Historical Theology: Before, During, and After Augustine (Eugene, OR: Cascade Books, 2008), 208.

${ }^{312}$ Karl Rahner, S.J., "The Doctrine of the Spiritual Senses in the Middle Ages," trans. David Morland, O.S.B., in Theological Investigations, vol. XVI, Experience of the Spirit: Source of Theology (New York: The Seabury Press, 1979),107. Rahner explained the trajectory of the doctrine of the spiritual senses as they were explicated by medieval writers through the ages. William of Auxerre, Alexander of Hales, Albert the Great, Thomas Aquinas, and St. Bonaventure are included in his comprehensive explanation.

${ }^{301}$ Camille, Gothic Art, 17.
} 
poor. ${ }^{314}$ Hence the activity was not an exclusive one. It did not require literacy or other privileges. Indeed the image served to support the meditative visualization. It follows that, when combined, the overlaid view of the Host and a Madonna lactans altarpiece formed a doubly potent locus where the physical and spiritual senses coalesced.

\section{The Madonna Lactans as an Altarpiece Image}

Images acted as facilitators for engaging the spiritual senses. Painted altarpieces introduced around the middle of the thirteenth century served as the ritual's physical and visual framework to stimulate feelings of devotion. ${ }^{315}$ Recent scholars have written about the function of the altarpiece, yet have failed to reach a consensus. Some argue for the late medieval altarpieces' liturgical function, namely that it was to augment the ritual being performed on the altar. Other scholars contend altarpieces were made for several purposes, including to inspire devotion. ${ }^{316}$ Beth Williamson's comprehensive study, Altarpieces, Liturgy, and Devotion, determined a multivalent function. ${ }^{317}$ She posited that the lines between the liturgical function and devotional function of an altarpiece are blurred. Because of the fervent devotion medieval people demonstrated to the Eucharist, the image behind the altar facilitated both a liturgical and devotional function. The liturgy was enhanced by the altarpiece, just as other liturgical furnishings aided the rituals performed in the sanctuary. Indeed the liturgy engenders devotion. Moreover, the

\footnotetext{
${ }^{314}$ Denise Despres, “Franciscan Spirituality: Margery Kemp and Visual Meditation,” Mystics Quarterly 11, no. 1 (March 1985): 13 - 14. See also Seubert, 143.

315 van Os, Sienese Altarpieces,vol. 1, 12.

${ }^{304}$ Barbara Lane, The Altar and the Altarpiece: Sacramental Themes in Early Netherlandish Painting (New York: Harper \& Row, 1984), 1. Lane gave a liturgical interpretation for the altarpiece. Kees van der Ploeg "How Liturgical is a Medieval Altarpiece?" in Italian Panel Painting of the Duecento and Trecento, ed. Victor M. Schmidt (New Haven, Conn.: Yale University Press, 2002), 115. Van der Ploeg suggested that because the altarpiece lacked canonical regulations like other liturgical furnishings - such as chalices, ciboria, and altars - it is not to be regarded as a liturgical object.

${ }^{305}$ Beth Williamson, “Altarpieces, Liturgy, and Devotion," Speculum 79 (2004): 341-406.
} 
altarpiece image incited the spiritual senses. The present author supports the multivalent interpretation for the altarpiece but argues that a particular motif represented on the altarpiece can inform its function.

In the instance of the Madonna lactans, an experiential interaction between the image and the churchgoer occurred. The nursing Madonna image filled a void left by the dearth of communion opportunities. But how was this Madonna type linked so closely to the Eucharist? According to Henk van Os, Madonnas in general -- all types -- became a favored subject because the image of the Virgin and Child suggested Christ's rebirth in the Eucharist; inherent, too, was the notion of Christ's Incarnation. ${ }^{318}$ An analogous relationship can be drawn between Mary becoming a virgin mother and the wonder of transubstantiation: both encompass extraordinary transformations. In one, the power of the Holy Spirit enables a young woman to become the mother of God without losing her virginity. In the other, the power of the Holy Spirit miraculously transforms bread into Christ's body without changing its physical shape or appearance. ${ }^{319}$ The act of nursing or feeding strengthens these metaphors of change from physical to spiritual essence, adding to both the concept of sustenance. The image, looming behind the elevated Host, provided the visual device necessary for the congregation to make this connection.

\footnotetext{
${ }^{306}$ van Os, Sienese Altarpieces, vol. 1, 14.

${ }^{307}$ The Eucharistic Prayer said before the consecration of the Host contains the Epiclesis, which is an "invocation" of the Holy Spirit. This example is from the Eucharistic Prayer III: "And so, Father, we bring you these gifts. We ask you to make them holy by the power of your Spirit, that they may become the body and blood of your Son, our Lord Jesus Christ ..." Felix Just, S.J., Basic Texts for the Roman Catholic Eucharist, Eucharistic Prayers I - IV, from the English translation of The Roman Missal (C) 1973, International Committee on English in the Liturgy, Inc., http://catholic-resources.org/ChurchDocs/EP14.htm.
} 


\section{An Altarpiece Fresco at Greccio}

An example from St. Francis's humble grotto in Greccio, Italy offers some novel eucharistic signifiers. On Christmas Eve in 1223, St. Francis of Assisi famously instituted the first celebration of the Nativity in a modest grotto with the original Christmas crib. ${ }^{320}$ For centuries before this the feast of Epiphany had been celebrated instead. St. Francis sought to shift the celebration's focus from adoration to the mystery of the Incarnation. Painted over the center of a modest altar in the actual grotto is a Nativity scene in which Mary nurses the Child Jesus (figs. 3.1 and 3.2). ${ }^{321}$ Located where the first celebration of the Incarnation took place, this simple fresco gave the faithful much to ponder. In the right-hand scene the suckling baby is tightly wrapped in the swaddling clothes mentioned in Scripture and apocrypha, but there is no mistaking that the bands of cloth are a foretaste of the shroud Christ would wear, and his bed is a stone sarcophagus. To the left is a second scene in which St. Francis is depicted kneeling in adoration of the swaddled/shrouded Christ Child, who is lying in his manger/coffin. Painted in the background on the left, a priest celebrates Mass on an altar where a chalice is in evidence. It is the cup of Christ's Precious Blood poured out for the salvation of humankind. It also serves as a reference to the Virgin, who carried Christ in her womb and was thus a vessel for his body and blood as well. The sacrifice taking place on the altar during Mass symbolizes the sacrifice Christ made for humankind. The altar and the tomb are parallel

\footnotetext{
${ }^{320}$ In 1229 Francis's biographer, Tomasso of Celano recorded the event: "When Francis came to the place, he found everything prepared and was well pleased. The manger was ready, the hay was brought, an ox and an ass were led in. Thus was holy simplicity honoured, holy poverty exalted, and gentle humility touched all hearts. Verily in that hour Greccio became a new Bethlehem." Tommaso of Celano The Lives of S. Francis of Assisi, trans. A.G. Ferrers Howell (London: Meuthen \& Co., 1908). Quoted in Neil MacGregor, Seeing Salvation, Images of Christ in Art (New Haven: Yale University Press, 2000), 49.

${ }^{321}$ The fresco is dated to the fourteenth century. See MacGregor, 50, and Erika Langmuir, Imagining Childhood (New Haven: Yale University Press, 2006), 94.
} 
signifiers. The symbols in the left-hand area of the painting reinforce and emphasize elements in the right-hand portion of the fresco.

Along with the nursing attribute, the symbols of Christ's Passion and death, of course, are inextricably linked to the Eucharist. Christ's death was simultaneously the nadir and zenith of salvation history. It marked the end of his ministry on earth as the Incarnate God and the beginning of his promise for salvation. His death was necessary to gain eternal life for all people and it reconciled humankind with their Creator. The night before he was put to death, he instituted the Eucharist at a seder or Passover meal, which included the customary consumption of bread and wine. ${ }^{322}$ At the Last Supper, instead of the traditional seder words, Jesus blessed the bread, broke it and gave it to his disciples, saying, "Take and eat, this is my body" (Matthew 26.26). Then he took the cup of wine, gave thanks and passed it among his followers, saying, "Drink from it, all of you; for this is my blood of the covenant, which is poured out for many for forgiveness of sins" (Matthew 26.27). The forgiveness of all of humankind's sins, for all ages, was accomplished through Christ's Passion, death, and Resurrection. At the Last Supper Christ instituted the eucharistic sacrifice of his body and blood, entreating, "Do this in memory of me" (Luke 22.29). The Mass is a commemoration of his suffering and sacrifice, memorialized sacramentally. Christ asked for the ritual to be repeated through the centuries to perpetuate the sacrifice and as a means to remain among the people. Thus he fulfilled his promise, "I am with you always, even to the end of the age" (Matthew 28.20). Christ was reborn in the faithful's hearts when they "received"

\footnotetext{
${ }^{322}$ The Seder traditionally comprised four parts. Drinking a cup of wine completed each section. The third part included the eating of the Paschal lamb and unleavened bread, known as the "bread of affliction" according to the Old Testament Exodus story. Joan Carter McHugh, Eucharist, God Among Us. Essays and Images of the Eucharist in Sacred History, Lake Forest, Il: Witness, 1999), 64.
} 
communion and contemplated the Madonna lactans image's eucharistic and salvific message. They were reminded that the Incarnate God now depends on human milk for sustenance, and that God's love for them was so great that he freely accepted his own death for them, but also promised to always be with them.

The Greccio fresco by an unknown artist, painted above the altar, united the symbols of Christ's suffering, the institution of the Eucharist, and the nursing Mother of God. Additionally St. Francis is portrayed kneeling on the ground adoring the Christ Child as Mass is being celebrated. The image of St. Francis reinforces the method of engaging the spiritual senses, showing the viewer how to participate in the celebration. The image reminds the faithful that the correct way to take part in the Mass is for people to look with their eyes and adore the Incarnate God with their whole heart. Francis adores the Incarnate God in the guise of a baby; Mass-goers should look and adore God Incarnate in the Host. The crude quality of the painting reflects both the grotto as a place and the sense of humility desired by St. Francis. The monk took the message of the Incarnation to heart. If God came in the peaceful and lowly guise of a helpless infant, then the celebration of that beginning should reflect that humility. A little over a century later the painter followed Francis's lead. The saint's emphasis upon Christ's humanity is everywhere in evidence in the fresco. And the nursing motif highlights the mother and Child's intimate, entirely human bond. We find the foundation of this theme in texts written by ancient philosophers, medieval monks, and late medieval theologians, an examination of which will reveal an intimate attachment between the body of Christ and his mother. 


\section{The Virgin and the Body of Christ}

Numerous texts known to medieval people associate and even equate the body of Christ with the Virgin. Ephraim of Syria is called Mary's first poet, and for him Christ's eucharistic body is identical to the body which came from his mother's womb.

Ephraim's writings about Christ never omit Mary, and he refers to Christ as bread and "grape from Mary.",323 Clement of Alexandria referred to Christ as the Infant Word and made the connection between Mary's nourishing milk and the Eucharist nourishment:

Calling her children about her, she nourishes them with milk that is holy: the Infant Word. . . . The Word is everything to His little ones, both the Father and Mother, both educator and nurse. 'Eat My Flesh,' He says, 'and drink My Blood.' $\mathrm{He}$ is Himself the nourishment that He gives. He delivers up His flesh and pours out His own blood. There is nothing lacking His children, that they may grow. ${ }^{324}$

Clement's writings unambiguously tie the nursing imagery with the ritual of Eucharist.

Paschasius Radbert, abbot of the monastery of Corbie in the ninth century, and well known for his reflections on the Eucharist, equated the sacrament with the Virgin. He explained, "[T]hat which is consecrated in Christ's word by the Holy Spirit is his body born of a virgin. $" 325$

But the strongest associations between the eucharistic body of Christ and his mother come later in Richard of St. Laurent's writings. He wrote his Marian work between 1239 and 1245, but the writings were attributed erroneously to his contemporary Albert the Great until about 1952, rendering them, according to Hilda Graef, betterknown than they otherwise might have been and scarcely criticized. Richard wrote,

\footnotetext{
${ }^{311}$ Hilda Graef, Mary: A History of Doctrine and Devotion (London: Sheed and Ward, 1963), 62.

${ }^{324}$ Clement of Alexandria, Christ the Educator, trans. Simon P. Wood, C.P., vol. 23 (New York: Fathers of the Church, Inc. 1954), 40.

${ }^{313}$ Miri Rubin, Mother of God, 104.
} 
"Mary [not God, as we read in John 3:16] so loved the world . . that she gave her onlybegotten Son for the salvation of the world." ${ }^{326}$ And, since Richard saw the union between the Virgin and Christ as inextricably linked, he wrote about receiving Mary's body, "In the sacrament of her Son we also eat and drink her flesh and blood." Moreover, "Mary feeds her guests ... on her virginal flesh ... also in the sacrament where the flesh of Christ and the flesh of Mary are consumed, since the flesh of the Mother and of the Son are one flesh." Graef objected, "[T]his view is quite inadmissible., ${ }^{.327}$ However, while Richard's writings about Mary were unacceptable to Graef's ear, we should consider his words with a "period ear."

\section{Mother's and Child's Shared Flesh}

An examination of what medieval people understood about a mother and her child's shared flesh and a look at the physiological theories behind it will make sense of Richard's unusual assertions. Two scientific ideas about conception known to people in medieval times link a mother and her child as one flesh. Aristotle posited that the mother provided the matter of the fetus and the father its spirit. This theory clearly binds the mother to the baby's physical body. The competing conception theory available to medieval people, that of Galen, suggested two seeds were necessary - one from each parent - associating both father and mother with the physiological matter. Galen saw the mother's womb as the vessel or oven in which the fetus cooks; the womb-matter provided the baby with what it needed to grow. ${ }^{328}$ His theory also united the mother and the

\footnotetext{
${ }^{314}$ Quoted in Graef, 266.

${ }^{315}$ Graef, 267.

${ }^{316}$ Bynum, Fragmentation and Redemption; Essays on Gender and the Human Body in Medieval Religion (New York: Zone Books, 1991), 214.
} 
newborn baby's body. St. Catherine of Siena $(1347-1380)$ wrote about Christ's and Mary's shared flesh. Speaking about Mary's suffering at the foot of the cross, she wrote:

Oh sweetest love, which was the sword that pierced the heart and soul of the mother! The Son was broken in body, the mother similarly, for his flesh was from her. Indeed it is just that she suffered in what befell him for he took his immaculate flesh from her.... He had the form of flesh and she, like hot wax, received the imprint of desire and love for our salvation from the sealing of the Holy Spirit, and by means of this seal the divine Word incarnate. ${ }^{329}$

St. Catherine understood the fundamental truth that Christ's flesh was from the Virgin, that it was the Virgin's flesh that endowed Christ with human form. Images of her nursing him confirm the inseparable connection. Augustine underscored the relationship vividly and went a bit further than St. Catherine, equating that bond with the eucharistic theme in his Explanations on Psalms: "For He received earth from earth; because flesh is from earth, and He took flesh from the flesh of Mary. He walked here in the same flesh, and gave us the same flesh to be eaten unto salvation. But no one eats that flesh unless he adores it." ${ }^{330}$ Augustine thus emphasized Christ's humanity when he spoke of the flesh Christ took from his mother, but also the exalted power of the flesh of each. Christ had no human father, so St. Catherine's and Augustine's assertions about Christ sharing his mother's flesh made sense. It was Augustine's inclusion of the eucharistic references that stands out, however. He, along with Richard of St. Laurent included phrases about eating of that flesh, thus making a clear connection to the Eucharist.

\footnotetext{
${ }^{329}$ Catherine of Siena, Le Lettere de S. Caterina, Letter 30, ed. Piero Misciatelli, vol. 1 (Florence: Guinti, 1970). Quoted in and translation by Bynum, Holy Feast, 265.

${ }^{330}$ Augustine, Saint, Explanations on Psalms [98. 9] AD 392 - 418, contributed by Eric Ewanco, Early Christians on the Holy Eucharist, http://www.columbia.edu/cu/augustine/a/eucharist-q.html.
} 
While these authors' ideas link the Eucharist and the nursing Madonna theoretically through the written word, the Madonna lactans as an altarpiece image visually unites the two. As mentioned earlier, the subject began to emerge from scattered origins in the thirteenth century and became increasingly popular in the fourteenth century, particularly in Tuscany. It served as a backdrop for the celebration of the Eucharist and fed devotion to the sacrament. And of course the image of a human mother feeding her son who needs his mother's milk to live underscored both Christ's humanity and the personal relationship between the Virgin and Child.

\section{Christ's Humanity Highlighted}

Barnaba da Modena painted an engaging version of the nursing Madonna as the central panel of a polyptych around 1370 for a Genoese client. The panel is now in the Musée du Louvre (figs. 3.3 and 3.4). Barnaba is documented in Genoa from 1361 to 1386. ${ }^{331}$ His painting reflects an earlier Byzantine style. In particular, gold striations describe the folds in the Virgin's mantle. (These striations were favored by the artist, since they occur in a number of Barnaba's Madonnas). But the artist hired assistants from Tuscany in the 1360s and the panel reflects Tuscan preferences also. The humanized baby is painted with golden curls, pink fleshy cheeks, and classical, cherubic lips poised at his mother's nipple (fig. 3.4). This more human Christ, portrayed as a baby playing with his foot as he nurses, typifies one of the Madonna lactans types emerging during the second half of the fourteenth century in Italy. The warm mother-child relationship is evident as well in the baby's grasp of his mother's hand. As such, the

\footnotetext{
${ }^{331}$ Atlas Database for the Musée du Louvre, Barnaba da Modena, http://cartelen.louvre.fr/cartelen/visite? srv=car_not_frame\&idNotice=1247\&langue=en.
} 
painting is a manifestation of the Franciscans' and other mendicant orders' teachings, which also reflected this humanization. The friars spread their devotion to Mary and Christ's humanization with charisma in sermons and devotional writings, and their words were universally embraced.

The Meditations on the Life of Christ mentioned earlier, written by an unknown Franciscan friar in the first half of the fourteenth century, provides one example of the humanization of Christ through devotional writing. Often called a period "best seller," the text encourages readers to visualize the New Testament scenes being described. Although there is no direct reference to the Virgin nursing the Christ Child in the New Testament, ${ }^{332}$ Meditations describes her nursing him and washing him, “[She] began to wash him with her milk, her breasts filled by heaven." The nursing imagery continues, "[W]atch her attentively as she cares for Him assiduously and wisely, nursing Him and rendering all services." 333 We return to St. Francis's biography written by his friend, Thomas of Celano, for another reference. Thomas recorded that St. Francis took enormous delight in the fact that when God became a human baby he needed his mother's milk. "The birthday of the Child Jesus Francis observed with inexpressible eagerness over all other feasts saying that it was the feast of feasts, on which God, having become a tiny infant, clung to human breasts. ${ }^{, 334}$ Francis's delight in Christ's human need of his mother's breast milk is clear. Here Francis vividly links the Incarnation to Mary's nursing activity, which is the basis for Mary's privileged status. Her success

\footnotetext{
${ }^{332}$ Luke 11.27 provides a single indirect reference. Addressing Jesus from a crowd, a woman called out, "Blessed is the womb that bore you and the breasts at which you nursed."

${ }^{321}$ Isa Ragusa and Rosalie B. Green, 33 and 39 respectively.

${ }^{322}$ Thomas of Celano, St. Francis of Assisi: first and second life of St. Francis, with selections from Treatise on the miracles of Blessed Francis, trans. Placid Hermann, O.F.M., (Chicago: Franciscan Herald Press, 1963), 296.
} 
when interceding for her devotees is tied directly to her role as the nursing mother, as we shall uncover in the next chapter.

These written sources, so well-known to late medieval people, furnish insight about the enthusiastic attitude toward the Virgin feeding and sustaining her Child, the Christ. The positive, even celebratory prose provides clues to how people at the time perceived the Madonna lactans image. They recognized that the Virgin alone nourished Christ's body, and they understood that Mary and Christ's relationship was mutually beneficial. God made a human being, Mary, an integral participant in his survival as a human. He became human to carry out the promise of salvation, to be accomplished through the shedding of his sacrificial blood, his death, and Resurrection. The consecration of the bread and wine into Christ's body and blood repeated the sacrifice. ${ }^{335}$ Well aware of Sacred Scripture, medieval people would have known that Christ made the promise, "I am the living bread that came down from heaven; whoever eats this bread will live forever; and the bread that I will give is my flesh for the life of the world" (John 6.51). The promise of eternal life could not have been fulfilled without Mary's complicity in whose womb the bread was cooked and from whom milk flowed to nourish him.

\section{St. Catherine of Siena}

St. Catherine of Siena is another late medieval Italian writer whose works reflect an explicit correlation between the Eucharist and nursing. We revisit the saint's

\footnotetext{
${ }^{323}$ The words said at the consecration of the Eucharist are taken from Scripture and are as follows: "Take this, all of you, and eat of it, for this is my body, which will be given up for you." "Take this, all of you, and drink from it, for this is the chalice of my Blood, the Blood of the new and eternal covenant, which will be poured out for you and for many for the forgiveness of sins. Do this in memory of me." See Matthew 26.26-29; Mark 14.22-26; Luke 22.15-20; and 1 Cor. 11.23-25. Brian MacMichael, "The New Translation of the Holy Mass," Today's Catholic News, http://www.todayscatholicnews.org/2011/02/the-newtranslation-of-the-holy-mass-12.
} 
reflections. One of our best resources about her was recorded by her confessor during the years of her public ministry. Raymond of Capua acquainted readers with Catherine's ardent devotion to the Eucharist. "All who knew Catherine were well aware of her profound and characteristic reverence and devotion towards the Blessed Sacrament of the Body of Our Lord." ${ }^{336}$ Additionally, her many extant letters and her Dialogue reveal a deep devotion to the body and blood of Christ. ${ }^{337}$ She is well-known as a mystic who fasted extensively, and against convention of the era, took communion frequently as a substitute for eating. ${ }^{338}$ According to her biographer, Christ appeared to Catherine in a vision, bearing the wounds inflicted during his Passion. During the apparition the Lord praised her for her virtuous abstinences and offered a reward she prized wholeheartedly.

[Christ said,] "I will give you a drink that transcends every human nature and expectation." And putting his right hand on her virginal neck and drawing her towards the wound in his side, He whispered to her, "Drink daughter, the liquid from my side and it will fill your soul with such sweetness that its wonderful effects will be felt even by the body which for my sake you despised." And she, finding herself thus near to the source of the fountain of life, put the lips of her body, but much more those of the soul, over the most holy wound, and long and eagerly and abundantly drank that indescribable and unfathomable liquid. ${ }^{339}$

Raymond's account of the apparition puts Christ in the role of nurse and Catherine in the role of communicant, thus drawing a parallel between the eucharistic blood of Christ and nursing. Further, Raymond quoted Catherine's explanation of the vision, underscoring the metaphorical portrayal of Christ as a nursing mother.

\footnotetext{
${ }^{336}$ Raymond of Capua, The Life of Catherine of Siena, trans., Conleth Kearns (Dublin: Dominican Publications, 1980), 288.

${ }^{337}$ Blessed Raymond reported The Dialogue is a work that Catherine dictated while taken up in ecstasy. She mentioned the Blood of Christ more than one hundred times within the work, continually demonstrating the efficacy of the sacramental Blood. Stephen Hawkins, "The Blood of Christ in the Life and Works of Saint Catherine of Siena: A Spiritual, Scriptural, Historical, Reflection Study." (M.A. Thesis, Mount Saint Mary's Seminary of the West, Athenaeum of Ohio, 1974), 18.

${ }^{338}$ Raymond of Capua, trans., Kearns, 288.

${ }^{339}$ Blessed Raymond of Capua, The Life of Saint Catherine of Siena, trans., George Lamb (New York: P.J. Kenedy \& Sons, 1960), $147-48$. The Lamb translation is more lucid in this instance. For another translation of the same passage see Kearns, 156.
} 
Father, do you know what the Lord did to my soul that day? He behaved like a mother with her favourite child. She will show it the breast, but hold it away from it until it cries; as soon as it begins to cry she will laugh for a while and clasp it to her and, covering it with kisses, delightedly give it her full breast. So the Lord behaved with me. That day, He showed me His most sacred side from afar, and I cried from the intensity of my longing to put my lips to the sacred wound. After He had laughed for a while at my tears - at least that is what He seemed to do He came to me, clasped my soul in His arms, and put my mouth to where His most sacred wound was, that is to say, the wound in His side. ${ }^{340}$

Thus, Catherine's own words make a strong association between the maternal act of nursing and the drinking of Christ's blood in the Eucharist. In fact, Bynum confirmed, "Catherine's own letters are filled with images of nursing from the breast of Christ." 341 Her Dialogue has an example. In it she relays God the Father's words to her, delivered while in an ecstatic state, in which Christ is the metaphorical wet nurse.

So the pus drained out of Adam's sin, leaving only its scar, that is, the inclination to sin and every sort of physical weakness - like the scar that remains after a wound has healed. Now Adam's sin oozed with a deadly pus, but you were too weakened to drain it yourself. But when the great doctor came (my only-begotten Son) he tended that wound, drinking himself the bitter medicine you could not swallow. And he did as the wet nurse who herself drinks the medicine the baby needs, because she is big and strong and the baby is too weak to stand the bitterness. My Son was your wet nurse, and he joined the bigness and strength of his divinity with your nature to drink the bitter medicine of his painful death on the cross so that he might heal and give life to you who were babies weakened by $\sin ^{342}$

Catherine not only analogized the act of nursing with the eucharistic consumption of

Christ's blood, but she referred to the breast of divine love and the milk drawn from it as the only means by which we can give nourishment to each other. Once we have fed ourselves there, we can help or nourish our neighbor. She wrote:

\footnotetext{
${ }^{340}$ Blessed Raymond of Capua, trans., Lamb, 173.

${ }^{341}$ Bynum, Holy Feast, 166. For more on this subject see chapter four. See also fig. 4.10 for Quirizio da Murano's fifteenth-century portrayal of Christ as lactating mother.

${ }^{342}$ Catherine of Siena, The Dialogue, trans., Suzanne Noffke, O.P. (New York: Paulist Press, 1980), 52.
} 
"It is truly good that we cannot give nourishment to another unless we have first nourished our soul with true and genuine virtues: and one cannot be nourished with virtues unless one is attached to the breast of divine love, from which breast one draws the milk of divine sweetness. ... Therefore we should hold ourselves fast to the breast of Christ crucified, in whom is the mother of love, and by means of his flesh we will draw the milk that nourishes our soul and the children of virtue, that is through the humanity of Christ. ${ }^{343}$

The means to a charitable end for St. Catherine was Christ's flesh and blood. For Catherine the milk drawn from the breast of divine love is the grace that feeds all souls.

The liquid in Christ's side was conflated. It was blood and milk.

\section{Blood and Milk}

The connection between blood and milk was muddled in the minds of the medieval people. They believed that breast milk was transmuted blood. According to Bartholomew Angelicus (d. 1272) blood reached the breasts through the veins and arteries and there turned into milk. Purification of the menstrual blood was considered to be one of the functions of the breasts. ${ }^{344}$ Clement of Alexandria (d. ca. 215) wrote an involved discourse about how this took place. He finished by equating milk with Christ's blood:

After childbirth, when the vein through which the blood was carried to the embryo has been cut off, then, with the passage obstructed, the blood is forced up into the breasts. As the blood accumulates, the breasts begin to distend and the blood begins to turn into milk. . . . Milk retains its underlying substance of blood. . . . It suffers change in its qualities, but not in its substance. . . ${ }^{345}$ But heavenly food is similar to milk in every way: by its nature it is palatable through

\footnotetext{
${ }^{343}$ Catherine of Siena, Le Lettere di S.Caterina, ed. Piero Misciatelli, vol. 2, letter 86 (Siena: Giuntini Bentivoglio \& Co., 1913 - 22), 81. The metaphors are repeated in other letters written by the saint. See Santa Caterina, Le Lettere, vol. 6, letter 2, p. 5.My gratitude to Msgr. William F. Cleves's for his help with translations.

${ }^{332}$ Bartholomaes Angelicus, 233 - 35 .

${ }^{345}$ Note, an exact parallel to the change made in the Eucharist can be made here. "It suffers change in its qualities, but not in its substance."
} 
grace; nourishing, for it is life; and dazzling white, for it is the light of Christ. Therefore it is more than evident that the Blood of Christ is milk. ${ }^{346}$

Was it more than evident to medieval churchgoers? When they gazed at the nursing Madonna painted on the altarpiece behind the altar, did they perceive a symbol of the Eucharist referenced by the blood and milk relationship? Did they make all of the spiritual and physiological connections?

Scholars wrestle with the question about understanding and applying meaning to religious images for period viewers. Michael Baxandall pointed to John of Genoa's late thirteenth-century Catholicon, a standard dictionary of the period, to answer questions about the function of religious art in the late Middle Ages. The Catholicon listed three reasons for the institution of religious images into churches: "First for the instruction of simple people .... Second, so that the mystery of the Incarnation and the examples of the Saints may be the more active in our memory ... . Third to excite feelings of devotion, these being aroused more effectively by things seen than things heard." ${ }^{347}$ It is noteworthy that all three of these articles were served by the Madonna lactans image. As discussed above, the image may have been used to instruct people about proper maternal feeding; the Incarnation theme is certainly highlighted in the image of the God-child needing human milk; and both public and private devotion to the Madonna lactans was aroused in people, as they gazed at the image behind the altar or prayed with the image in their private homes, as we have demonstrated.

The Catholicon definition represented an attitude handed down through the ages that likely entered the medieval people's consciousness; people in the Middle Ages

\footnotetext{
${ }^{334}$ Clement of Alexandria, 38-39. See also Gellius, 357.

${ }^{335}$ Michael Baxandall, 40-41.
} 
customarily embraced wisdom of ancient and late antique philosophical predecessors. ${ }^{348}$

Of course interpreting an image as a signifier of a particular message for every medieval viewer remains problematic. But when considered together with textual evidence and the period's larger understanding of the power of seeing and the power of images, one can reasonably conclude that the faithful saw a correlation between the Eucharist and the Virgin feeding her Son. And recall that the image's popularity began building after the Lateran decree, suggesting perhaps a more vital reason for its existence, namely as this study proposes, that its function was related to the practice of spiritual communion, ignited when frequency of actual communion reception came to an end. However, more than a simple correlation may have occurred. For people who engaged with the image, it may have actually been a sacramental or, as Josef Jungmann described activities not encompassed by the seven sacraments, an extra-sacramental. ${ }^{349}$

\section{The Image as a Sacramental}

As exhibited in this analysis, the Fourth Lateran Council's decree concerning Christ's real presence in the Host resulted in deepened devotion to the Eucharist, and a heightened appetite for it, engendered by infrequent eucharistic reception. Additionally

\footnotetext{
${ }^{336}$ For example Paulinus of Nola defended the decision to paint images in churches, saying "the majority of the crowd here, however, are peasant people, not devoid of religion but not able to read. [They] are at last converted into proselytes for Christ while they admire the works of the saints in Christ open to everybody's gaze." Paulinus of Nola, Carmina XXVII, 512 - 95, in Paulinus' Churches at Nola, Academisch Proefschrift door Rudolf Carel Goldschmidt (Amsterdam: N.V. Noord-Hollandische Uitgevers Maatschappig, 1940), 61-65. Quoted in Caecilia Davis-Weyer, Early Medieval Art 300-1150 (Toronto: University of Toronto Press, 1986), 18-19. Pope Gregory I famously did the same in the late sixth century in a letter to the Bishop Serenus of Marseille. He reprimanded the iconoclastic bishop, defending the necessity of religious images thus: "What scripture is to the educated, images are to the ignorant." And: "It is not without reason that tradition permits the deeds of the saints to be depicted in holy places." Pope Gregory I, Sancti Gregorii Magni Epistolarum Lib. XI, Epist. 13, Patrologia latina, ed. J. Migne, LXXVII (Paris: 1849), cols. 1128 - 30. Quoted in Davis-Weyer, 47-48. Therefore, medieval churchgoers likely expected the image above the altar to edify and instruct just as the written word did.

349 Jungmann, vol. 2, 202-217. See also Richard C Trexler, "Florentine Religious Experience: The Sacred Image," Studies in the Renaissance 19 (1972): 34 n. 81.
} 
the Lateran decree must have affected the way people saw images. It is reasonable to conclude that if medieval people believed that bread and wine could become divine, an image of the supernatural was a plausible object of transference as well. As Michael Camille put it: “. . A visual thing was itself capable of becoming and not just signifying its prototype. ${ }^{350}$ In this light, could an image laden with eucharistic implications, further compounded as worshipers gazed upon the transubstantiated bread and wine, truly become or provide something divine? Because of their ability to stimulate the spiritual senses, medieval religious images became channels through which one could encounter the supernatural. Medieval people understood the power of vision differently than we do today. Margaret Miles described the difference: "The human mind was capable of grasping supernatural truth through visible objects because visible objects both reflect and participate in the being of their prototypes. ${ }^{, 351}$ Hans Belting's meticulous study sheds light on viewers' responses to images through the medieval period. His analysis complements Miles's. Belting explained that the medieval viewer experienced "a recognition of the cult image not as an aesthetic illusion or as a work of an artist but as a manifestation of a higher reality - indeed, as an instrument of supernatural power.",352 These scholars' descriptions of medieval viewers' experiences with religious images coincide agreeably with this study's assertion that contemplating the Madonna lactans image was a sacramental occurrence. Images were facilitators to access the supernatural for medieval people. If seeing the Host was tantamount to receiving it in spiritual communion, why would people not believe that they also received something divine

\footnotetext{
${ }^{338}$ Camille, The Gothic Idol, 217.

${ }^{351}$ Miles, "The Importance of Vision in Fourteenth Century Italy" in Image as Insight, 66-68.

${ }^{352}$ Belting, 47.
} 
when they contemplated the image of the nursing Madonna behind the ritual consecration?

The type of image at issue here sometimes portrays Christ pausing at the breast and looking directly at the faithful, inviting them to partake, as in Agnolo Gaddi's Madonna with Child of ca. 1390 (fig. 3.5). In Agnolo Gaddi's painting the Christ Child pauses just before eating and looks directly out at the viewer. Bynum noted this sort of invitation, and proposed that when Christ is depicted at the breast, but not nursing, he seems to "invite the viewer toward the breast ... [hence] some assimilation of Mary's milk and the blood of the eucharist may be intended." 353 Williamson agreed with Bynum but put it more emphatically, suggesting that the assimilation was intended in "many if not most Virgin lactans images." 354 I add to the discussion that the Virgin, too, looks out at the viewer in many of these examples, as she does in a work by Puccio di Simone - a Madonna of Humility in the central panel of a polyptych (fig. 3.6). In Puccio di Simone's altarpiece Mary's gaze is directed at the viewer and the Christ Child looks at his mother. The invitation in this case comes from the Virgin. In light of the evidence equating Mary's milk with Christ's body and blood, her invitation is no less eucharistic.

Furthermore, in images like those by Barbara da Modena and Agnolo Gaddi both Mother and Child engage and invite the spectator (figs. 3.3, 3.4, and 3.5). Both glances are eucharistic invitations; both are a summons to "take and drink," as Christ encouraged at the Last Supper. It must have been a matter of great emotional and spiritual privilege

\footnotetext{
${ }^{353}$ Bynum, Holy Feast, 271. The iconographic detail of the Christ Child staring at the viewer is employed by Ambrogio Lorenzetti in his earlier Madonna del Latte usually dated to 1340 (fig. 3.7). Here Christ's torso twists purposely to lock eyes with the viewer, and he uses his foot to push against his mother's arm in order to turn. This emphatic gaze at the spectator is so deliberate it may also be an example of Christ offering a eucharistic invitation, although in Lorenzetti's painting he has not stopped nursing to do so. ${ }^{354}$ Williamson, "Virgin Lactans," 244.
} 
when devotees comprehended the invitation. Here Christ and his Mother looked directly at them. When the offer for sustenance, intercession, and mercy came from both subjects, as in these two paintings, it must have been doubly enticing to spiritually hungry viewers. And the devotee returned the gaze. The activity of gazing in a liturgical context was an intense experience for medieval worshipers. Thus engaged, they likely utilized these images as an instrumental link to supernatural power. Hence the image would have been perceived as sacramental.

As Richard Trexler observed, most religious behavior was basically sacramental; however he cautioned that not all of the seven sacraments per se, as they are known today, were part of the "average religious mentality" 355 of medieval and Renaissance people. Activities associated with sacraments were more commonly embraced. Trexler offered the sacraments of Eucharist and Confession as examples. "To see the host was a matter of great emotional excitement; to eat it was an occasional, secondary religious requirement. To speak with and trust an image was common; to confess to a priest was not. ${ }^{, 356}$ It is not far-fetched to attach believers' interaction with the inviting Madonna lactans image to Trexler's idea, especially in this period when reception of the Eucharist was rare, that is, to receive the body and blood of Christ was a rarity, but to receive the grace and efficacy of the Eucharist in the nurturing, nourishing image of the Madonna lactans image was available and inviting. Thus, what appears to us today as an accompanying action or a secondary activity to the sacrament was considered a more deeply religious or spiritual activity to people of the period and may have actually served as the sacrament itself. The goal of religious behavior was to receive something from or

\footnotetext{
${ }^{355}$ Trexler, "Florentine Religious Experience," 34.

${ }^{356}$ Trexler, "Florentine Religious Experience," 34.
} 
to connect with the divine, and images were facilitators. Trexler added, "Personal relations with images ... represent . . the strongest of all religious impulses: to exchange powers with God."357

The era's definition of a 'sacrament' further supports our hypothesis. Tertullian (AD c. 160-220), an ecclesiastical writer from the second and third centuries is thought to have introduced the term 'sacrament' in its religious sense. ${ }^{358} \mathrm{He}$ wrote about the sacrament as a sacred sign:

The flesh is washed that the soul may be made spotless. The flesh is anointed that the soul may be consecrated. The flesh is signed (with the cross) that the soul too may be protected. The flesh is overshadowed by the imposition of the hand that the soul may be illumined by the Spirit. The flesh feeds on the Body and Blood of Christ that the soul also may be replete with God. ${ }^{359}$

Even in this early writing, Tertullian attributed some kind of causality to the sacred sign so that the flesh [the human] may be filled with God. St. Augustine (AD $354-430$ ) explored the meaning of a sacrament in greater depth and defined it further as having the power to effect what it signifies. Reflecting St. Augustine, William Cleves explained, "The earliest definition that we have of 'sacrament' is two words: signum efficaxeffective sign, that is, a sign that actually brings about what it signifies." ${ }^{360}$ For medieval people the image of the Virgin feeding her Son as a visual backdrop for the consecration of the Eucharist may have embodied such an effective sign. It signified sustenance, and it brought about that sustenance in Christ who offered his body as food, food that promised eternal life. Hugh of St. Victor penned De Sacramentis at the beginning of the twelfth century, contributing an important advance in sacramental theology. He wrote:

\footnotetext{
${ }^{357}$ Trexler, "Florentine Religious Experience," 34.

${ }^{358}$ David Bourke, "Introduction," in St. Thomas Aquinas's Summa Theologiae, trans. David Bourke (New York: Blackfriars - McGraw-Hill Book Company, 1975), xv.

359 Tertullian, De Resurrectione carnis 8. PL 2, 806, trans and ed. Ernest Evans (1960) http://www.tertullian.org/articles/evans res/evans res_00index.htm.

${ }^{360}$ Msgr. William F. Cleves, e-mail correspondence with the author, November 2009.
} 
A sacrament is a physical or material element admitted to the perception of the external senses, representing a reality beyond itself in virtue of the similitude it bears to it, actually pointing to that reality in virtue of having been instituted as a sign of it and containing within itself some invisible and spiritual grace in virtue of having been consecrated. ${ }^{361}$

Thus, applying Hugh of Saint Victor's definition, we can assert: a material element (like an image of the nursing Virgin) admitted to the perception of the external senses (eyesight) represented for medieval people a reality beyond a simple likeness. Based upon this description it is not unreasonable to say that for the medieval audience, as a sign, the image contained "within itself some invisible and spiritual grace."

Bishop Durandus explicated Gregory the Great's theological writings at the end of the thirteenth century. He reiterated Gregory the Great's definition of when sacraments transpired: “. . . there is a sacrament in any celebration when an outward act is so performed as that we receive inwardly some degree of the thing signified."362 Again, the employment of Gregory's definition of a sacrament fits our hypothesis for the nursing Madonna, that medieval devotees believed they received inwardly a degree of the spiritual sustenance it embodied when viewing such an image. St. Thomas Aquinas, too, explicated and dissected the meaning of 'sacrament' in his Summa Theologice written $1265-1274$. His treatise on sacraments is quite involved. For him a sacrament was dynamic. The flow of grace is caused by the sacrament. He asserted, "A sacrament of the New Law is an instrumental cause of grace. . . But grace is in a sacrament in the sense of flowing through it ... A sacrament derives its spiritual power from Christ's blessing." 363 Therefore grace flows from Christ into the recipient through the sign itself.

\footnotetext{
${ }^{361}$ Hugh of Saint Victor, 155.

${ }^{362}$ Durandus, Rationale, 142.

363 Thomas Aquinas, The Sacraments, 3a. 62, vol. 56, Summa Theologice, trans. David Bourke (New York: Blackfriars - McGraw-Hill Book Company, 1975), 1 - 3.
} 
The image of Mary nursing signified and hence became sustenance for the Savior and for those gazing at it. Their sustenance was the grace which flowed from the signifier (the nursing Madonna image) to the supplicant, through Christ's power. The Madonna lactans image signified the Virgin's role in nourishing, and the faithful understood that they were the recipients of that nourishment. By applying these definitions of sacrament to the Madonna lactans altarpiece image, an image "capable of becoming, not just signifying its prototype," with the spiritual senses engaged, medieval people likely perceived the image as a sacramental and relied on the experience for a connection to the supernatural. This was no small matter for spiritually hungry medieval supplicants. 


\section{CHAPTER IV \\ VIEWERS, VISIONARIES, VOYEURS RECEPTION OF THE RENAISSANCE MADONNA LACTANS IMAGE}

"[Beauty is] the harmony and concord of all the parts, achieved in such a manner that nothing could be added, taken away, or altered." - Leon Battista Alberti

In the Renaissance period conventions about greater naturalism were applied to the Madonna lactans, and Mary's breast no longer looked like an unattached sphere, as in late medieval versions. Some scholars maintain that anatomical realism negated the image's sacred meaning, making it erotic or potentially provocative for viewers. But in most cases, painters of the image either de-emphasized the non-feeding breast or left it out entirely, thus preserving the sacred symbolism of a nurturing mother. The asymmetrical Madonna was not a titillating image. We shall discover that numerous factors diminished the possibility of a prurient reading of the image. The nursing Virgin was not painted in the manner that erotic women were painted at the same time, breastfeeding was commonplace during the era and not considered indecent, and scientific studies show that a woman's asymmetrical chest was not sexually attractive in the way that paired full breasts were. Moreover, sacred signifiers canceled any erotic implications for the Madonna lactans image. It is tempting to assume that the nursing Madonna would resonate differently for females than for males. But this chapter 
suggests that the new naturalism applied to the image was not disruptive for most, and the image's message of intercessory help was attractive to men and women alike. We find that nuns identified with the Virgin Mary as mother, daughter, and bride of the triune God. Their emulation of Mary sometimes occurred in visions in which they nursed or were nursed by Christ. Men, however, had similar visions. We shall discover that the Madonna lactans image aided meditative prayer, and its perceived mystical power facilitated a deeply personal encounter with Christ for both sexes.

One nun is of particular interest to this study because she drew a nursing Madonna for her own private edification. Suor Plautilla Nelli risked going against her convent's strict Savanarolan spirituality. The preacher left stern directives concerning modesty in renderings of the Virgin Mary. Nelli created the image to possess her own Madonna lactans. The exquisite drawing is fully resolved and elaborated, and we find no finished painting for which her drawing may have been a preparatory sketch. Her desire for a private devotional Madonna lactans must have been ardent. She likely perceived the image of Mary as a means to intimacy with Christ, just as the nuns before her did. But first, an exploration of how the image was not perceived will be instructive.

The claim that the image was sexually stimulating would only pertain to a segment of the population who would be susceptible to arousal by an exposed female breast, for those who would view a naked breast as titillating. Megan Holmes considered only some people's responses when she wrote that the motif "became too disruptive."364 This chapter will attempt to fill the gap. But before we examine how the image may have

\footnotetext{
${ }^{364}$ Holmes, 178.
} 
functioned for a mixed Renaissance audience, we must first address more pointedly the issue of its reception as an image with prurient connotations.

The Renaissance Madonna lactans image reflected the period's new emphasis on naturalistic depiction. In the earlier trecento, images of the Madonna lactans portrayed her bare breast as an awkward addendum to her body, a non-integrated appendage, and it often was given an unnatural shape and small size (fig. 1.2). While the image of the late medieval nursing Madonna has been well-studied, academic interest in the Renaissance version is scarce. Among the small number of scholarly explorations of the Renaissance image a few scholars concluded that the nursing Madonna was provocative because of its naturalistic execution and the employment of partial nudity. Thus, some scholars alluded to audiences as voyeurs.

For example, Georges Gharib claimed that the Renaissance nursing Madonna had "become just a pretext to show off the female body." 365 Holmes further argued that Renaissance naturalism made the image provocative. ${ }^{366}$ She used Masolino da Panicale's Madonna and Child of 1425 as an example of the change in the Renaissance image (fig.4.1), observing that the Madonna's “breast is revealed and clarified in Masolino's picture." She noted that both the placement and the anatomical proportion of the Virgin's breast adheres to Renaissance principles of correct anatomy and is in keeping with "new dictates of pictorial naturalism." 367 But Holmes concluded that, in time, an enhanced naturalism made the Madonna lactans image too pruriently suggestive to be used

\footnotetext{
${ }^{365}$ Georges Gharib, "La Vergine che allatta. Tu che nutri colui che da la vita," in Madre di Dio, vol. 58, (December, 1990), 17 - 20, quoted in Gian Paolo Bonani and Serena Baldassarre Bonani, Maria Lactans, (Roma: Edizioni “Marianum" 1995), 57.

${ }^{366}$ Holmes, 175 - 178.

${ }^{367}$ Holmes, 175.
} 
successfully as a spiritual devotional image. She declared, "What I would like to suggest is that the pictorial conventions for rendering the Virgin's breast that had been perfectly acceptable in the early quattrocento became too disruptive when a premium was placed on naturalism in the visual arts as a representational means to more didactically efficacious images." ${ }^{368}$ To a point Holmes is accurate, for indeed, the Virgin's breast is rendered with anatomical accuracy in both its positioning and shape in the Renaissance version of the nursing Madonna. But Holmes missed one important observation. In Masolino's painting the Virgin's right breast - the non-feeding breast - is absent. The blue mantle covers much of the area where the breast should be, but the orange gown under the mantle is also visible, and it does not swell with the shape of a breast. In fact, the majority of Renaissance depictions of the theme lack a non-feeding breast. The area where a breast should be is flat. Frequently, no swollen shape is articulated beneath the Virgin's gown at all. The absence of the non-nursing breast has as much significance to the meaning of the image as the "revealed and clarified" nursing breast. In the face of all of the emphasis upon anatomical correctness, why the omission of the other breast? Why is the nursing Madonna lopsided? One problem with the Holmes hypothesis is that full naturalism would call for the rendition of two breasts. Yet in most of these images, only one breast is rendered, and thus naturalism has been sacrificed. Be that as it may, Holmes proposed that when new dictates about naturalism were applied to the Renaissance version of the Madonna lactans image, they rendered the image too provocative for effective devotional reception.

\footnotetext{
${ }^{368}$ Holmes, 178.
} 
A close study of numerous Renaissance Madonna lactans images does reveal a more correct anatomical rendering of Mary's breast, as Holmes suggests, but the fact that often only one breast is articulated diminishes the claim for the employment of naturalism in the image. Rather, the imbalance in the anatomy of this Marian icon asserts its symbolic function, mitigating the potential for a lascivious reading. The absence of the other breast preserved its sacred message.

\section{Voyeurs?}

An appreciably large segment of the Renaissance population would not, could not, see an image of the Mother of God as sexually arousing, disturbing, or erotic, and it retained its potency as a devotional image with which people engaged in prayer. Several factors enter the discussion here. We mentioned a few above. To repeat, they are: the approach artists undertook to paint an erotic subject versus a sacred one, the science of asymmetrical attractiveness, and the common sight of women breastfeeding. Furthermore, we shall find that there were no laws governing breastfeeding in public but there were very particular sumptuary laws governing modesty in women's dress. As well, didactic writings such as Leon Battista Alberti's treatise on painting advocated naturalism and proportion as defining elements of beauty, so one must question why their directives were ignored in the case of the Madonna lactans.

The Renaissance era lopsided Madonna was common. Out of one hundred and fifty-three Italian images of the nursing Madonna from the beginning of the fifteenth century through the first quarter of the sixteenth century examined in this study, the fully articulated shape of the non-nursing breast is present in only twelve images. That is a 
mere eight percent (see Chart 1). In some of the images - one quarter of the total - the veil covers the area where the other breast would be, but without a swollen shape beneath it, or there is an unnaturally small swelling underneath the gown. In another fourth of the images the Virgin's hand or arm or a part of the Christ Child covers the area where the non-feeding breast would be. Andrea Solario's Madonna with the Green Cushion in the Louvre is an example of this latter type (fig. 4.2). However, in the majority of the Renaissance images the area where the non-feeding breast would be is unnaturally flat, with no attention paid to the female anatomy at all (fig. 4.3). ${ }^{369}$

A comparison of the nursing Madonna by Solario and a Cleopatra by the same artist shows how correct anatomy is deployed for the sake of eroticism and how distortion shifts the painting's meaning. Andrea Solario painted a number of versions of the nursing Madonna motif in the early years of the sixteenth century, none of which shows signs of two natural breasts. In each painting he either covered the space where the nonfeeding breast would naturally be with Mary's arm or he painted an unrealistically small bulge in the gown next to the larger, exposed feeding breast, as in the Virgin Nursing the Christ Child in the Columbia Museum of Art (fig. 4.4). If we compare Solario's treatment of breasts in his painting of a classical subject, Cleopatra, we see that Cleopatra has two evenly sized breasts (fig. 4.5). As in Solario's Virgin Nursing, Cleopatra has one exposed breast and one draped, yet in the case of the classical subject there is no mistaking the anatomical symmetry of both breasts. Cleopatra's draped breast is obviously full and round and the same size as the exposed one. Naturalism has been

\footnotetext{
${ }^{369}$ These 153 images were gathered from such sources as ARTstor, The Foundazione Federico Zeri University of Bologna, The Index of Christian Art - Princeton University, and from images found during my research and travels.
} 
faithfully employed. Her exposed breast serves a different purpose than in the Madonna lactans painting. The ancient queen famously committed suicide, and according to the legend she chose her breast as the place for an asp's deadly, venomous bite. ${ }^{370}$ Solario's Cleopatra is the antithesis of the Virgin. Represented in history as a beguiling seductress, Cleopatra's predominantly red gown (with applications of blue) symbolizes her reputation as a powerful and lustful enchantress. The Virgin's colors are the reverse, mostly blue and white and with only a little red, indicating her purity and heavenly character. In comparable three-quarter-length formats both paintings depict women who use two hands to firmly grip the objects of their attention. One holds a snake, the other the Christ Child. Both figures' downcast eyes contemplate their different fates. One contemplates death, the other life. The Virgin considers the life made possible through nurturing a Savior who promised eternal life. Conversely, Cleopatra is lost in thought about ending her own existence.

Ancient writings about Cleopatra available in the Renaissance period characterized her as a seductress who used her sexuality to gain power. Her nemesis was Octavian, who is thought to have generated the Roman propaganda that, in the century after her death, described her as "a dangerous harlot who employed sex, witchcraft and cunning." The Roman poet Lucan (A.D. 39 - 65) labeled her the "shame of Egypt, the

\footnotetext{
${ }^{370}$ Amy Crawford, "Who was Cleopatra?" Smithsonian.com (April 1, 2007), 2. http://www.smithsonianmag.com/history-archaeology/.../cleopatra.html. Historians agree that to escape capture by Octavian Cleopatra killed herself around August 12, 30 B.C. The method of her death is uncertain, but the snake's venomous bite on her breast survives in legends. Of the method Plutarch wrote: "The truth of the matter, no one knows." Stacy Schiff, Cleopatra: A Life (New York: Little Brown and Company, 2010), 286. Schiff wrote of the "asp theory," "Cleopatra's asp is the cherry tree of ancient history. . . It made poetic sense and good art. (So did the naked breast, also not part of the original tale.)" Octavian added to the lore by making a model of Cleopatra with an asp to symbolize his triumph.
} 
lascivious fury who became the bane of Rome." ${ }^{371}$ In A.D. 75 Plutarch's Life of Antony recorded a less damning account, but her allure was still characterized as bewitching and irresistible. ${ }^{372}$ Following Octavian's model, fourteenth-century author Boccaccio called her "the whore of eastern kings," and Dante placed her in his second circle of hell for her sin of lust. ${ }^{373}$ Solario endeavored to portray a libidinous, voluptuous queen. He included two full, round breasts for the effect.

In Solario's painting of the Virgin in Columbia, as in other Italian Renaissance Madonna lactans images, the deliberate distortion of her breast anatomy was, in itself a message. When we compare it to the Cleopatra by the same artist, also which presents the breast in a starring role, we receive a very different message. Solario's Cleopatra is the consummate powerful, seductive queen, and her breast is also the locus of her legendary suicide. Two equally fleshy round breasts, one covered and one bared, nipple and all, located at the center of the composition, are part of the artist's iconographic arsenal to tell the story of a lusty ruler's final act of valor. In the Virgin Nursing the Christ Child Mary looks down at her baby with great affection, her expression demure. One breast is covered and abnormally smaller than her feeding breast, which is partially wrapped in the undergarment of a nursing mother with a slit to accommodate that function. The nipple is not visible because the Christ Child takes it in his mouth to eat. Here, the breast was intended to feed the Christ Child. The image of the Virgin thus presented was received by most Renaissance viewers as sacred and communicated a message about feeding, intercession, and salvation. It seems apparent that when the

\footnotetext{
${ }^{371}$ Crawford, 2.

${ }^{372}$ Crawford, 2.

${ }^{373}$ Schiff, 299.
} 
artist's objective was to depict a narrative with an erotically charged subject such as Cleopatra, he used a different set of signifiers. On the other hand, generally Madonna and Child images serve an iconic purpose. For the Madonna lactans example, if both of the Virgin's breasts were visible or articulated with anatomical accuracy through her garment, the image might have been a bit more sexually charged. The intentional asymmetry, among other such signals, served to extinguish any spark.

As we can see, Andrea Solario was fully capable and willing to include breast symmetry in his work when he deemed it appropriate for his purposes. In fact, during the Renaissance period symmetry in art was advocated in written instructions. Vitruvius wrote about the concept of symmetry as early as the second half of the first century B.C. in his Ten Books on Architecture, which is noteworthy as one of the first theoretical discussions about symmetry and was reprinted in a whole series of translations at the end of the fifteenth century, providing a significant link between Antique and Renaissance thought. ${ }^{374}$ Philosopher, artist, architect, and mathematician Leon Battista Alberti wrote several books about aesthetics. On Painting was the first in his series of didactic works for painters, sculptors, and architects. Both a practical "how to" guide for painters and a celebration of the art form, On Painting often invoked the wisdom of ancient philosophers, and Vitruvius in particular was a favorite. Because of its immediate success, the original Latin version of his De picture, written around 1435, was translated into the Italian (Vulgare) Della pittura a year later to reach a larger audience of artists,

\footnotetext{
374 György Darvas, Symmetry: Cultural-historical and Ontological Aspects of Science-Arts Relations: The Natural and Man-made World in an Interdisciplinary Approach, trans. David Robert Evans (Basel: Birkhauser, c.2007), $49-51$. http://books.google.com/books?id=UYdsSrZF0mgC\&pg=PA50\&lpg=PA50\&dq=Leon+Alberti+symmetry \&source.
} 
patrons, and academics. Alberti was likely the first to use the word symmetria in regard to proportions and correct relationships when painting the human form. ${ }^{375}$ His instructions were specific about observing the body's proportions in nature. "As Nature clearly and openly reveals all these proportions, so the zealous painter will find great profit from investigating them in Nature for himself." His lessons about painting the human form were precise: “. . just as for a clothed figure we first have to draw the naked body beneath and then cover it with clothes, so in painting a nude the bones and muscles must be arranged first, and then covered with appropriate flesh and skin in such a way that it is not difficult to perceive the positions of the muscles."376 Alberti’s work was widely read and its dictates embraced by scores of Renaissance artists. His deep influence on Italian Renaissance art is well documented. ${ }^{377}$ Yet his instructions about observing proportion and draping the natural, nude form with clothes were routinely ignored by painters of the Renaissance Madonna lactans. In a majority of these images, the non-feeding breast is either not rendered at all or it is irregularly small beneath the Virgin's veil or gown. The naturalism, balance, and symmetry that Alberti championed were deliberately skewed.

Skewing anatomical symmetry left the Virgin's body subtly distorted, thereby rendering it sexually unappealing. The amount of literature about the sexual attractiveness of bodily symmetry is vast. In evolutionary, biological, and behavioralscience studies, distortion of bodily symmetry has been found to be unattractive. For example, in their research Steven W. Gangestad and Glenn J. Scheyd found, "Bilateral

\footnotetext{
${ }^{375}$ Darvas, 50.

${ }^{376}$ Leon Battista Alberti, "Excerpts from On Painting, 1436," in Arts Humanities: Primary Source Reader, Book II, section 3, no. 36. http://www.mcah.columbia.edu/arthumanities/pdfs/arthum raphael reader.pdf .

${ }^{377}$ For instance, "Even a cursory examination of Raphael's Marriage of the Virgin will reveal many of Alberti's principles at work." See introduction to ibid, 1.
} 
asymmetry on features that, on average within a population, are symmetrical may reflect perturbations occurring during development due to mutations, pathogens, toxins, and other stresses. Manipulations of symmetry of signals ... affect attractiveness.” 378 According to this study, and many like it, symmetry is linked to perceptions of phenotypic and genetic quality and is thought to be a mark of general fitness, parasite resistance, and good health, all of which increase mating appeal. Conversely, deviations in bodily symmetry or, fluctuating asymmetry (FA), as it is called, are believed to have a negative effect on fecundity. "In human females, higher levels of breast asymmetry are associated with lowered fecundity. ${ }^{379}$ To explain this, Devendra Singh ascertained that men are sensitive to quite small differences in female breast asymmetry. Singh gave her research subjects drawn images of women with varying waist to hip ratios (WHR) and breast symmetry and asymmetry. Her goal was to determine whether subtle differences in breast asymmetry were discernible and what those differences demonstrate about attraction. She defined attraction by asking subjects to rate their willingness to "engage in a casual short-term romantic fling and to have a serious long-term romantic relationship on a scale of 0 (least willing) to 20 (very willing). ${ }^{380}$ She concluded: "Breast asymmetry affected judgments of attractiveness; the figure with symmetrical breasts was assigned significantly higher attractiveness than the other two figures with low WHR but with asymmetric breasts." 381 These studies and a host of others like them

\footnotetext{
${ }^{378}$ Steven W. Gangestad and Glenn J. Scheyd, "The Evolution of Human Physical Attractiveness," in The Annual Review of Anthropology, eds. William H. Durham, Jean Comaroff, and Jane Hill, vol. 34 (Palo Alto: Annual Reviews, 2005), 535.

${ }^{379}$ David Waynforth, "Fluctuating Asymmetry and Human Male Life-History Traits in Rural Belize," Proceedings: Biological Sciences, vol. 265, no. 1405 (August 22, 1998), 1497. In his work Waynforth defined fecundity as a high number of offspring and lifetime number of sex partners.

${ }^{380}$ Devendra Singh, "Female Health, Attractiveness, and Desirability for Relationships: Role of Breast Asymmetry and Waist to Hip Ratio," Ethology and Sociobiology 16, no. 6 (November, 1995): 487.

${ }^{381}$ Singh, 470.
} 
show that sexual attraction depends on bilateral bodily symmetry, and this attraction is apparently anthropologically encoded to ensure a reflection of good health and resistance to pathogens in one's mate.

Behavioral scientists have conducted research on many and varied populations, with little disparity in the conclusions about symmetry and attractiveness. For example, David Waynforth studied fluctuating asymmetry and its effect on fecundity in rural Belize, a non-industrialized population. His goal was to reach conclusions reflecting those representing the entire span of human history. He wrote of his study, "The significance of this is that these populations have exposure to pathogen and fecundity levels closer to those experienced by individuals during the vast majority of human existence. Non-industrialized populations are thus living under conditions closer to those for which humans are biologically adapted." ${ }^{382}$

The conclusions reached in Waynforth's research are pertinent to the present study because the Renaissance audience was a pre-industrialized, largely illiterate population. The difficulty in researching how an image was received by Renaissance-era women and men, whose voices were infrequently recorded, is thus helped by research that applies to human behavior across time and cultures. The human reaction to images, specifically sexual attractiveness to asymmetrical factors, is well documented and by extension provides a clue about how the image of the lopsided nursing Madonna was not received five to six hundred years ago. Based upon studies about deviations in bodily bilateral symmetry and its negative effect on sexual selection such as those cited above, the image was surely not a sexually alluring one. For her research, Singh asked college

\footnotetext{
${ }^{382}$ Waynforth, 1497.
} 
men her questions. Waynforth asked rural farmers in non-industrialized Belize. ${ }^{383}$ I chose these studies from among a vast pool of research in this regard because their subjects best reflect the sort of Renaissance Italian viewers about whom I wish to apply reception and response theories concerning an image with an asymmetrical body. While it is true that images of Mary were rendered with increased naturalism in the Renaissance period, that naturalism did not extend to a symmetrical portrayal of the Virgin's chest. The employment of naturalism was, to be sure, applied to better placement and anatomical correctness of the breast that was depicted, but the other breast remained illdefined or entirely absent. In fact, the nursing Madonna image's skewed naturalism deemphasized its sexual allure in favor of a message of nurturing. But these findings alone are not enough to draw a conclusion. Other cultural aspects of Renaissance life must be considered.

For instance, the activity of breastfeeding was not an unusual sight in a society in which human milk was the only good option for feeding babies. Public breastfeeding was not thought to be indecent and therefore, taboo. The sight of a woman nursing was a common one in the early modern period, not a forbidden scene or one regulated by law, as is the case in the twenty-first century United States. Currently forty-five states and the District of Columbia have laws allowing breastfeeding in public places. In five states nursing one's baby is not allowed in public. Twenty-eight states and the District of Columbia exempt breastfeeding from public indecency laws. That means that presently breastfeeding one's infant in public is not exempt from laws governing indecency in

\footnotetext{
${ }^{383}$ Waynforth asked fifty-six subjects in isolated villages who "practice subsistence-level slash and burn farming and others involved in a cash economy." Waynforth, 1497.
} 
twenty-two states. ${ }^{384}$ No law existed in Renaissance Italy concerning breastfeeding in public. In their comprehensive study, Trevor Dean and Kate Lowe examined records in which all the offenses for which Italian Renaissance women could have been in violation are catalogued. ${ }^{385}$ No laws about breastfeeding are included. It is likely that nursing mothers in the Renaissance period may have been out and about less often than modernday women, warranting less regulation. However, an inspection of every manner of Italian Renaissance sumptuary law reveals the extent to which the smallest minutiae of women's dress and activity were regulated, especially dress and activities having to do with feminine sexual provocation, a hot-button issue garnering a good deal of apprehension at the time. The feminine décolletage was a key site for sumptuary-law intervention. These sumptuary laws attest to a preoccupation with the exposition of a woman's breast as a violation of modesty and moral codes. For example, a Renaissance Sienese statute of 1436 stated: ". . no woman or female child from the age of ten . . would be allowed to wear and to show more flesh on the front than two fingers from the pit of the throat, so that no uncovered bosom is seen." ${ }^{386}$ In 1464 a Florentine law allowed for just three centimeters of female skin to show from collarbone to dress neckline. In Milan, a sumptuary law of 1498 specified that women's necklines should be no lower than one finger (placed sideways) below the collarbone. ${ }^{387}$ Yet, anxiety about

\footnotetext{
${ }^{384}$ For more about the governance of breastfeeding in the USA see "Breastfeeding Laws," National Conference of State Legislators, updated May, 2011, http://www.ncsl.org/issuesresearch/health/breastfeeding-state-laws.aspx.

${ }^{385}$ Trevor Dean and Kate Lowe, "Writing the History of Crime in the Italian Renaissance," in Crime, Society and the Law in Renaissance Italy, Trevor Dean and K.J.P. Lowe, eds. (Cambridge: Cambridge University Press, 1994), 9-11.

${ }^{386}$ C. Falletti Fossati, Costumi senesi nella seconda meta del secolo quattordicesimo (Siena, 1881), 136. Quoted in Women in Italy, 1350 - 1650, Ideals and Realities: A Sourcebook. Selected, translated and introduced by Mary Rogers and Paola Tinagli (Manchester: Manchester University Press, 2005), 101. 387 Alan Hunt, Governance of the Consuming Passions: A History of Sumptuary Law (New York: St. Martin's Press, 1996), 222.
} 
the exposed décolletage did not reach the activity of nursing. If the sight of a woman nursing a baby was construed as indecent, it would have been legislated. Therefore it is reasonable to assert that the Renaissance image of a woman nursing would not have been considered sexually arousing either, especially when it was an image of a specific mother - the Mother of the Savior - steeped in a tradition of devotion and sanctity. Again, one must suppose, the distortion of naturalism - the presence of only one breast - in the Madonna lactans image emphasized the message of feeding, eradicating any inkling of the objectification of the Virgin Mary in it.

Moreover most of the period's Madonna lactans images included holy signifiers haloes, crowns, a throne, or celestial beings like saints and angels. Of the 153 Madonna lactans images used in the present study, eighty-three percent of the Madonna lactans images included one or more of these holy signifiers, triggering long-rooted feelings of reverence or supplication in the image's audience. Additionally, the image's surroundings, that is, where the Madonna lactans image was hung, had much to do with the way it was received. If the image was hung in a church above an altar or in a side chapel, it stands to reason that the smells, sounds, and sights the viewer encountered in a place of worship worked together with the image's sacred signifiers, prompting thoughts related to veneration, intercession, or gratitude for prayers answered. The scent of candles and incense burning, the sounds of the priest's liturgical invocation, choirs singing or chanting, and bells ringing were sensory triggers. Stained glass windows, statues of saints, reliquaries, wall and apse mosaics and frescoes decorated with titular saints or Old and New Testament scenes, and the church architecture were visual stimuli. The power of the Church's visual ritual has already been discussed in chapter three. It 
would have been similar, though not as potent, for devotional images hanging in private homes. Recall the altar-like settings that surrounded artwork used for private devotion (fig. 2.10 and 2.11). Bedchambers were equipped with devotional images to which candelabra, votive candles in wall sconces, and aspergilla were attached. The candelabra and candles illuminated the image and, as in a church, signified a sacred space. The aspergillum or situla was a receptacle for holy water. Additionally, Renaissance Italians knelt before devotional images with prayers incised into their frames. ${ }^{388}$ The presence of these elements in bedrooms replicated the liturgical settings in parish churches and reminded people of being in a sacred space. The sacredness of such household spaces warranted comment from San Bernardino, who warned women that they should never pray before their images shamelessly dressed. His warnings included the removal of cosmetic jars or ampoules from the hallowed space. ${ }^{389}$

Furthermore, Renaissance Italian devotion to the Blessed Virgin was so ardent among the general population that for the majority of people, considering such a revered sacred patroness as a source of prurient stimulation is difficult to imagine. Recall that throngs of people crowded piazzas and hung from windows as the image of the Virgin Mary was paraded through streets on her feast days and in thanks for favors perceived to have been granted by her intercessory powers. Small images of the Virgin and Child in altar-like settings were a common locus for prayer and supplication in Italian Renaissance bedrooms and private chapels. And people frequently expressed thanksgiving and praise through valuable votive offerings left at the foot of public Marian images. To ignore all

\footnotetext{
${ }^{388}$ Newbery, Bisacca, and Kanter, 39.

389 Bernardino da Siena, Le Prediche Volgare, V, 206f, quoted in Trexler, Public Life, 69.
} 
of these practices and behaviors is to misunderstand the sanctity accorded to the image of the nursing Madonna.

\section{Visionaries - Nuns}

We have examined what the image likely did not mean to many Renaissance Italians. Let us turn now to what meaning it may have held and whether it carried a different meaning and function for men and women. The image was frequently the object of conventual devotion. An exploration of how nuns as brides of Christ responded to the Madonna lactans image will provide insight.

The image of the Madonna lactans was apparently a potent one for nuns in the late medieval and early modern periods. There is evidence that nuns used images of Mary nursing as a visual aid for their public and private devotional activities. What women, particularly nuns, perceived when they gazed at the Madonna lactans image can be pieced together through some significant historical clues recorded in history. For example, Queen Marie de’ Medici loved and admired Solario's Madonna with the Green Cushion (fig. 4.2) so much she took possession of it, removing it from the convent of the Cordeliers at Blois, where it initially hung. The nuns there were bereft. The sisters in the convent at Blois were already attached to the devotion when the Queen usurped the image. They were "obliged to content themselves with a copy."390 If the nuns went so far as to have the image replicated, their devotion to the Madonna lactans must have had deep roots. Given that the Queen was able to view the image, we can assume it was hanging in a public area of the convent where all of the nuns had access to it. Whether

\footnotetext{
${ }^{390}$ David Alan Brown, “Andrea Solario," in The Legacy of Leonardo: Painters in Lombardy, 1490 - 1530, ed. Francesco Porzio (Milan: Skira Editore S.p.A., 1998), 246.
} 
individual nuns engaged in contemplative prayer before it is impossible to say, yet we know they did not want to live without it, certainly evidence of their attachment or devotion. Indeed, nuns' devotion to the Madonna lactans motif is recorded elsewhere.

A Dominican convent in Venice was another place where zeal for the motif was evident, although the nuns engaged with it in the privacy of their own cells. A series of Madonne dell'Umilita paintings was executed by Andrea di Bartolo for that community, to be hung in each of the cells. The nuns' new spiritual advisor Giovanni Dominici, saw that the images were installed in time for the foundation's dedication ceremony in June, 1394. ${ }^{391}$ Accordingly, each of the nuns had the image of the nursing Madonna available for their personal, private devotion. Dominici again recommended the theme in a 1403 sermon in which he named the most moral painted and sculpted subjects. "The Virgin Mary is good to have, with the child on her arm,... A good figure would be Jesus suckling, [or] Jesus sleeping in his Mother's lap ...”392 The National Gallery of Art in Washington D.C. owns a small devotional panel by Andrea di Bartolo, which Creighton Gilbert has identified as one of the panels the artist painted for the Venetian nuns' cells (fig. 4.6). ${ }^{393}$ The panel, now separated from an accompanying image, balanced the Madonna of Humility on one side with a Crucifixion on the other in a diptych arrangement. Due to its small size (11.7 x 7.2 in.), devotion to it necessitated viewing at

\footnotetext{
${ }^{391}$ van Os, Sienese Altarpieces, vol. 2, 76. Ann Roberts, Dominican Women and Renaissance Art: The Convent of San Domenico in Pisa (Aldershot, Hampshire: Ashgate, 2008) 21-24. For a description of the dedication ceremony see Sister Bartolomea Riccoboni, Life and Death in a Venetian Convent: The Chronicle and Necrology of Corpus Domini 1395 - 1436, trans. and ed. Daniel E. Bornstein (Chicago: University of Chicago Press, 2000), 32-34.

${ }^{392}$ Giovanni Dominici, Rule for the Management of Family Care, Part IV (1403), quoted in Creighton E. Gilbert, Italian Art, 1400 - 1500: Sources and Documents, ed. H. W. Janson (Englewood Cliffs: Prentice Hall, 1980), 145.

${ }^{393}$ Gilbert, Creighton E. "Tuscan Observants and Painters in Venice, ca. 1400," in Interpretazioni veneziane: Studi di storia dell'arte in onore di Michelangelo Muraro (Venice: Arsenale, 1984), 109-120. See also van Os, vol. 2,76. See also Roberts, 21. Roberts dates the painting to ca. 1394, van Os does not ascribe a date to the image, and the National Gallery of Art website assigns c. 1415 to the piece.
} 
close proximity. A tiny figure of a nun kneels at the bottom right corner of the painting, a place usually reserved for the patron of an artwork. Gilbert maintained that the nun is wearing an undergarment, the layer of clothing under the Dominican nun's habit. ${ }^{394}$ The only place she would be in such a state of undress is in the privacy of her own cell, as she prepares for bed. The garment is not her nightdress, since she still wears her wimple. (An example of the Dominican habit underlayer is visible in Fra Angelico's Eighteen Dominican Beati from a Dominican altarpiece in Fiesole [fig. 4.7].) What is so extraordinary is that, if Gilbert's assessment is correct, this panel is a visual record of the Dominican nuns' private devotion to the nursing Madonna because it is actually a picture of a nun in the intimate state of undress reserved for a private moment, praying before a nursing Madonna image. Clearly, the nuns' devotion to the Madonna lactans is deeply intimate and personal.

A story about how the image helped generate a religious experience in a Tuscan monastery demonstrates just how powerful the image was as an aid to meditative prayer. The Monastery of Camalduli is situated in a thousand-year-old forest of the TuscanRomagnese Appennines and was founded around 1024. Blessed Paula of Florence lived there in the fourteenth century, and instead of directing her gaze outward to take in the beautiful views, she spent her days contemplating the image of the nursing Madonna in her cell. Her unwavering affection was rewarded, as the legend goes, by special visitors. In honor of her faithfulness, the Virgin and her nursing Son appeared to Paula in her cell

\footnotetext{
${ }^{394}$ Gilbert, Interpretazioni veneziane, 114. Anabel Thomas, Art and Piety in the Female Religious Communities of Renaissance Italy (Cambridge: Cambridge University Press, 2003), 116.
} 
in 1368. The Christ Child granted a few drops of his mother's milk to fall on Paula's lips. $^{395}$

It is tempting to see the convent as an incongruous place for such a wellspring of devotion to the nursing Mother, since most nuns did not marry, give birth, or suckle babies. While this is true of the majority of nuns, there were instances of widowed women taking the veil. ${ }^{396}$ In Le sette armi spirituali, a spiritual guide for the Clarissan nuns, St. Catherine of Bologna prompted these widowed women to channel their experience as mothers into being spiritual mothers to Christ, to transform a basic human emotion that they knew from actual experience into spiritual love. ${ }^{397}$ Apparently the transformation from human emotion to spiritual love was accomplished by unmarried, celibate religious as well. As we shall see, visual culture, texts, and memoirs survive that elucidate the ardent devotion the Madonna lactans motif inspired in convents and monasteries. The image functioned as a prompt for the imitatio Mariae, facilitating a deep intimacy with God.

Women religious felt an affinity with the Virgin Mary on three levels. The triune God - Father, Son, and Holy Spirit - cast Mary in the role of God's daughter, mother, and spouse. Most Renaissance women could easily identify with being God's daughter. As sponsae Christi - brides of Christ - young women entering the convent were given liturgical cradles in which a doll-like figure of Christ was placed (fig. 4.8). ${ }^{398}$ Similarly, a little doll of the Infant Jesus, called a bambino, was counted among items in a young

\footnotetext{
${ }^{395}$ Meiss, Black Death, 152. See also Warner, 199.

${ }^{396}$ For the diversity in convent communities see Thomas, $33-54$.

${ }^{397}$ Jeryldene M. Wood, Women, Art, and Spirituality, The Poor Clares of Early Modern Italy (Cambridge: Cambridge University Press), 138.

${ }^{398}$ Carolyn Walker Bynum, Fragmentation and Redemption: Essays on Gender and the Human Body in Medieval Religion, New York: Zone Books, 1991), 199.
} 
girl's wedding trousseau or was given to her as a gift when she entered the convent. Nannina Medici, sister of Lorenzo the Magnificent, in 1466 received such a doll in her trousseau. And in 1446 Sister Angelica, baptized Costanza, took the veil for the order of St. Clare of Monticelli, whereupon she received a doll as a gift from her father. ${ }^{399}$ Thus, at the juncture when a young woman's matrimonial destiny was determined, either as earthly brides, or mystical brides of Christ, these dolls figured into their rites of passage. Cloistered "mothers" changed, kissed, fondled and sometimes placed the Infant Christ dolls at their breasts. ${ }^{400}$ The private ritual and response to images is apparent in these activities. As Anabel Thomas concluded, these practices offer evidence of private conventual ritual, distinct from the more formal ceremonies associated with convent life. ${ }^{401}$ Corresponding to this, the popular fourteenth-century Meditations on the Life of Christ, written for Poor Clare nuns, encouraged devotion to the Infant through caring for him. "Kiss the feet of the infant Jesus who is laid in his bed, and ask Our Lady to give him to you and allow you to pick him up. Receive him and hold him in your arms. Look at his face with attention and kiss it with respect. ${ }^{, 402}$ The devotee is directed to visualize the Virgin's motherly care: “[W]atch her attentively as she cares for Him assiduously and wisely, nursing Him and rendering all services. ${ }^{, 403}$ The popularity of this text is well established. It was copied word for word and versions of it were rendered into rhyming

\footnotetext{
${ }^{399}$ Christiane Klapisch-Zuber, "Holy Dolls: Play and Piety in Florence in the Quattrocento," in Women, Family, and Ritual in Renaissance Italy, trans. Lydia Cochrane (Chicago: University of Chicago Press, 1985), 311-317.

${ }^{400}$ For more about ritualistic tending to Infant Jesus effigies see Klapisch-Zuber, 324; Trexler, Public Life, $189-90$.

401 Thomas, 134.

${ }^{402}$ Quoted in Klapisch-Zuber, 323.

${ }^{403}$ Ragusa and Green, 39.
} 
verse. ${ }^{404}$ Its directives appear to have been followed in ritual and in the form of mystical visions, always in the name of devotion.

Typical of this is the tale of Saint Agnes of Montepulciano, who, after praying ardently to meet the Infant Jesus, received him from his mother's arms in a vision. "Find[ing] joy in his embraces" Agnes refused to give him back to the Virgin Mary. The Virgin used flattery and threats until Agnes relinquished him but not before putting up quite a struggle. ${ }^{405}$ In this tale, Agnes was keen to be close to the Christ Child and to satiate her motherly longing. The baby played a passive role. The relationship is onesided. A relationship with more depth is revealed in Rosemary Hale's account based on some fourteenth century German Dominican convent texts. ${ }^{406}$ These chronicles of ecstatic visions and dreams in which nuns spiritually gave birth, just as Mary did without having "known" a man - and suckled the Christ Child, often include "speaking" wooden doll effigies given to them upon entering the convent. Margaretha Ebner, a nun at Engelthal, had such a vision:

I have an image of the child, our Lord, in a cradle. I was so powerfully compelled by my Lord with great sweetness, longing and desire and also by his request because it was said to me by my Lord: "If you don't give me to suckle, then I will take myself away at the moment you love me most." So I took the image out of the cradle and laid it on my bare breast with great longing and sweetness and felt then the strongest possible grace in the presence of the Lord. Afterward I wondered how our blessed Lady could ever endure the incessant presence of God. ... But my longing and my desire is to nurse the Christchild so that through his pure humanity I might be purified and set afire by him with his burning love, and his presence and sweet grace would pour through me so that I would be motivated

\footnotetext{
${ }^{404}$ Klapisch-Zuber, 323; Meiss, Black Death, 125-126.

405 "De s. Agnete virgine ord. sancti Dominici Montepolitiani," Acta sanctorum, April II, 797. Quoted in Klapisch-Zuber, 325.

${ }^{406}$ Rosemary Hale, "Imitatio Mariae: Motherhood Motifs in Devotional Memoirs," Mystics Quarterly 16, no. 4 (December, 1990): $193-203$.
} 
by the true enjoyment of his divine essence together with all the loving souls who have lived in truth. ${ }^{407}$

Margaretha wished to be purified and to be graced by Christ's humanity and his divine essence. She longed for a new level of closeness to God, and as she achieved it she wondered how the Virgin Mary could tolerate such intense, sustained proximity. Hale reasoned that because the manuscript was copied (three pre-sixteenth century manuscripts are extant), that it may have provided exempla and "pious rationale" for meditative prayer and devotional ritual. ${ }^{408}$

Yet another example: as cloister chaplain, Friederich Sunder prepared to celebrate the Eucharist, "he says that he often prayed to experience a spiritual motherhood Gottesgeburt in der Seele, the birth of the Son in the Soul."409 He had a vision of Christ, born in his soul, and Christ spoke to him, saying:

You have often desired me and asked my holy mother that she should intercede that I be spiritually born in you. Now I have two mothers: Maria, who is my physical mother, and you my beloved soul, my spiritual mother. I have now nourished you with myself and now you should spiritually nourish me. And give me your right breast that I may nurse and be spiritually nourished. ${ }^{410}$

Here and in the female nun's account, breastfeeding Christ is a powerful spiritual event. Both people were using the imitatio Mariae as an agent to a mystical union with God specifically in giving birth to and nursing Christ. The mystical rather than the physical is underscored by reading the man's experience, since breastfeeding was an impossibility for him. It opens up the opportunity for the experience to all believers. In this light, contemplation of an image of the nursing Virgin makes sense. Notice that in both

\footnotetext{
${ }^{407}$ Hale, 196.

${ }^{408}$ Hale, 197.

${ }^{409}$ Hale, 197.

${ }^{410}$ Siegfried Ringler, "Das gnaden Leben des Friedrich Sunder, Klosterkaplan zu Engelthal," in Viten-und Offenbarungsliteratur in Frauenklöstern des Mittelalters: Quellen und Studien (München: Artemis Verlag, 1980), $391-44$, quoted in Hale, 197.
} 
accounts, Christ asked to be nursed. The give and take was explicit. What is so extraordinary is the reciprocity in the nourishment. The mystic was not a mere supplicant, begging for mercy or divine favors. The level of intimacy increased through Christ's plea to be nourished. Imitating Mary came with the privileged level of responsibility of providing God with the thing he most needed to live. How much more intimate is a relationship when there is mutual need, mutual giving. Such a mystical experience was not, however, the only avenue to achieve this level of intimacy.

In his exploration of images dating from 1500 found at St. Walburg, a Benedictine monastery in Eichstätt, Jeffery Hamburger described twelve drawings that both stimulate and record the nuns' devotion. In the drawing Consecration of Virgins the inscription says, "“Accipe puerum Istum et nutria michi, ego dabo tibi mercedem tuam” (fig. 4.9). "Take this boy and take care of [literally, suckle] me. I will give you a reward.",411 In the first part of the sentence, "Take this boy," the Virgin's entreaty mirrors the consecration rite, conducted by the bishop, in which the nun accepts Christ as her spiritual spouse. Hamburger explained that the second part is an unexpected change of voice. "After Mary commands the assembled virgins to accept her Child, the infant Christ issues an imperative of his own, 'Suckle me!",412 Once again the Christ Child asked to be nourished, this time in the inscription for an image that was painted by a nun. Christ promised a reward for the act of charity. In the inscription an appeal is made for the nun-viewer to first identify with the Virgin as Christ's bride and then as his mother, as provider of nourishment through nursing. The second entreaty, from Christ, fostered

\footnotetext{
${ }^{411}$ Jeffery F. Hamburger, Nuns as Artists: The Visual Culture of a Medieval Convent (Berkeley and Los Angeles: University of California Press, 1997), 56.

${ }^{412}$ Hamburger, 56.
} 
reciprocal intimacy, with the inducement of a reward, though the reward was not named. One did not need to reach the exceedingly pious level of devotion visionaries achieved to attain reciprocal intimacy with God. The nun-artist painted a consecration ritual available to all sisters, but also bearing an inscription in which Christ made an overture. In fact, Christ's request for food would have been familiar to people of the period who read or heard proclamations of sacred texts.

Scripture itself is full of instances when Christ asks for something to eat and drink. "Jesus said to them, 'Children, have you caught anything to eat?" (John 21.5). ${ }^{413}$ And in another passage, "While they were still incredulous with joy and were amazed, he asked them, 'Have you anything here to eat?' They gave him a piece of baked fish; he took it and ate it in front of them" (Luke 24.41-43). In still another passage, Christ approaches a Samaritan woman and says, "Give me a drink" (John 4.7). In these three examples Christ asks to be fed, privileging his benefactors with fulfilling his desires - his needs - deepening the love between them; in effect, Christ says, "I need you." The bond is not easily broken now. Furthermore, in Scripture Christ made an explicit link between feeding and loving him.

When they had finished breakfast, Jesus said to Simon Peter, "Simon, son of John, do you love me more than these?" He said to him, "Yes, Lord you know that I love you." He said to him, "Feed my lambs." He then said to him a second time, "Simon, son of John, do you love me?" He said to him, "Yes, Lord, you know that I love you." He said to him, "Tend my sheep." He said to him a third time, "Simon, son of John, do you love me?" Peter was distressed that he had said to him a third time, "Do you love me?" and he said to him, "Lord, you know everything; you know that I love you." [Jesus] said to him, "Feed my sheep" (John 21.15-18).

\footnotetext{
${ }^{413}$ All sacred texts are from the New American Bible (Washington D.C.: Confraternity of Christian Doctrine, 1970) unless otherwise noted.
} 
As the Good Shepherd, the Lord knew that his flock needed to be nourished, and Peter (and every disciple) was bound by love to do the job. In the mystics' visions and in the drawing's inscription Christ himself asked for the sustenance. The request brought the faithful into an intimate inner circle, a love relationship that must have been intoxicating, even addicting.

In other accounts the situation was reversed. Angela of Foligno and Catherine of Siena were nursed by Christ. ${ }^{414}$ Catherine's letters are full of images of her nursing from the breast of Christ; her biographer, Raymond of Capua, referred to Christ's wound as a "fountain," and Catherine calls the wound in Christ's side his "breast." ${ }^{415}$ Metaphorically the wound in Christ's side is often conflated with a breast.

The utter love expressed as Christ invites intimate contact with it is apparent in two other chronicles. In the first, besides envisioning nursing at Christ's breast, Angela of Foligno, experienced "in her soul" an extraordinary display of Christ's motherly love for Angela's "spiritual sons." The chronicle does not clarify who these "spiritual sons" were, but her biographer recorded her account of the vision:

Suddenly a multitude of the sons of his holy mother appeared around the blessed and sorrowful Jesus. And he embraced each one of them with great love, and his hands drew each one's head close to himself as he made them kiss the wound at his side... There seemed to be varying degrees of intensity of the way her sons were embraced and placed to Christ's side. He thrust some of them into his side some more, some less, some more than once and some he absorbed deep into his body. ${ }^{416}$

\footnotetext{
${ }^{414}$ Bynum, Fragmentation, 162.

${ }^{415}$ Bynum, Holy Feast, 166 and 371 n. 72.

${ }^{416}$ Angela of Foligno, Angela of Foligno, Complete Works, trans. Paul Lachance, O.F.M. (Mahwah, NJ: Paulist Press, 1993), 246.
} 
Angela was aware that the varying degrees of intensity "fitted the various degrees of Christ's intimacy with each of the sons," and she struggled to adequately represent in words the deep and tender love she witnessed in Christ as he embraced each son. ${ }^{417}$ In the second narrative, Julian of Norwich's Revelations of Divine Love put emphasis upon Mother Jesus imagery and the heavenly joy awaiting us. "The human mother may put her child tenderly to her breast, but our tender Mother Jesus simply leads us into his blessed breast through his open side, and there gives us a glimpse of the Godhead and heavenly joy - the inner certainty of eternal bliss. ${ }^{4118}$

Carolyn Walker Bynum has shown that the idea of Christ as mother has roots that date to the second century. ${ }^{419}$ Clement of Alexandria's Paedagogus devotes lengthy passages to the theme of the nursing Christ. There he developed the analogy between God, who feeds humankind with his flesh and blood in the Eucharist, and a human mother who feeds her child from her own blood/milk. ${ }^{420}$ The lactating Jesus is suggested in a fifteenth-century painting by Quirizio da Murano, who painted it for a monastery of Poor Clare nuns on the island of Murano. The Savior now hangs in the Accademia, Venice (fig. 4.10). Christ's wound, normally depicted lower and in his side, is here located frontally and higher on his torso. Quirizio painted the wound where the breast would be, and Christ's fingers splay in the so-called scissor or V-hold around the opening in his garment like a nursing mother offering the breast. It is a cousin to the Madonna lactans image. Here, instead of his Mother, Christ offers nourishment to the spectator, or

${ }^{417}$ Foligno, $246-47$.

${ }^{418}$ Quoted in Nelson Pike, Mystic Union: An Essay in the Phenomonology of Mysticism (Ithaca: Cornell University Press, 1992), 73 - 74.

${ }^{419}$ Carolyn Walker Bynum, Jesus as Mother: Studies in the Spirituality of the High Middle Ages (Berkeley and Los Angeles: University of California Press, 1982), 126, 128.

${ }^{420}$ Bynum, Holy Feast, $270-271$ n. 59. 
in this case to the devoted nun in the bottom left corner. The image is a unique one, which makes the fact that nuns commissioned it all the more fascinating. Its patronage underscores conventual commitment to the idea of reciprocal nurturing between Christ and the sisters.

Moreover, with his other hand Christ, in Quirizio's painting proffers a host to the devotee, emphasizing the Eucharist, the sacramental consumption of his Body and Blood from his side wound. Recall our previous chapter pairing nursing with the Eucharist. Certainly God's special, deep love and the reward of eternal paradise are prized results of these intimate encounters with Christ's breast/wound as he takes on a maternal role. Eternal life as a reward for reciprocal feeding is inherent in sacred texts. When the Samaritan woman questioned Jesus at the well about the water he requested of her, he replied "Everyone who drinks this water will be thirsty again; but whoever drinks the water I shall give will never thirst; the water I shall give will become a spring of water welling up to eternal life (John 4.13-14)." In the same way, when the faithful eat his body and drink his blood, Christ promises eternal life. Christian ritual uses eating and drinking to bring the faithful into a close communion with God, one that will forever quench their spiritual thirst. "Whoever eats my flesh and drinks my blood has eternal life, and I will raise him up on the last day. For my flesh is true food, and my blood is true drink. Whoever eats my flesh and drinks my blood remains in me and I in him (John $6.54-56) . "$ This, then, is the reward inferred by the inscription in the drawing at St. Walburg, "Suckle me [and] I will give you a reward!" The nun-artist that wrote that inscription knew the stakes were high; the reward was eternal life. Communion with God was understood as simultaneously mystical and corporeal. 
The image of the nursing Madonna facilitated a connection to this deep level of mutual love through feeding and the great reward inherent in the sharing. Therefore, we can make sense of the nun who loved nothing better than to contemplate the Madonna lactans image every day at Camalduli, or the separation anxiety caused by the removal of a beloved painting of the image at Blois. The meaning behind the devotion is clear. In light of nuns and visionaries being asked by Christ to take him up and suckle him, or their own feeding at Christ's breast, together with references in sacred Scripture and insight into devotional rituals involving Christ-dolls, the fervent devotion is understandable. Devotion before the Madonna lactans cultivated a deep communion with the divine in a way no other image could have done. So in this context, when celibate women and men spoke of giving birth and nursing, the metaphorical expressions were considered models to be imitated, neither sexual nor peculiar in nature. ${ }^{421}$

\section{Female Patrons and Artists of the Madonna Lactans Image}

Understanding how women responded to the image extends to examining women who commissioned and painted it. Margaret Miles wrote, "Images of the nursing Virgin are men's images; as far as can be determined, not a single image of this type was commissioned or painted by a woman until the seventeenth century." ${ }^{422}$ On the contrary, there are several recorded instances in which women either commissioned the image or painted it themselves in Renaissance Italy. For example, a Lady Datuccia commissioned such an image to adorn an altarpiece in Pisa in the last years of the fourteenth century

\footnotetext{
${ }^{421}$ In the context of period literature, stories written in early Renaissance Italy featured breastfeeding in ways that would be considered odd today. The chronicles of visionaries' suckling Christ should be viewed through this lens. For example Giovanni Boccaccio wrote a story about a grieving woman, who, marooned on an island, began to suckle two newborn kid-goats. Giovanni Boccaccio, The Decameron: Selected Tales, ed. Bob Blaisdell (Mineola, NY: Dover Publications, 2000), story VI, 38.

${ }^{422}$ Miles, Secularization of the Breast (2009), 47.
} 
(fig. 4.11). The text at the base of the panel leaves no doubt. More specifically, this painting, now in Budapest, tells the viewer that the widow had the panel painted by Taddeo di Bartolo in memory of the souls of her father and husband. It is another Madonna of Humility type. Mary is seated on the ground and is surrounded by seraphim. Angels place a jeweled crown on the nursing Virgin's head. The crown is inscribed with Mater Misericordiae, Mother of Mercy. ${ }^{423}$ The Infant Jesus takes his mother's breast in both hands, preparing to nurse, as he looks directly at the viewer. ${ }^{424}$ Lady Datuccia had the altarpiece made for the sacristy chapel in Pisa's San Francisco, where it stayed until the nineteenth century when it was dismantled and reframed. Its importance is highlighted by a number of authors, including Vasari in the sixteenth century and again by G. della Valle and A. da Morrona in the eighteenth century. ${ }^{425}$

By some estimates, there were copious numbers of female patrons of the nursing Madonna image in convents. In fact, van Os thought the number is incalculable, calling it the image 'par excellence' of convent life. "Countless images of the Madonna lactans sitting on the ground must have hung on the walls of convent cells." ${ }^{426}$ He also situated it within a liturgical context: "Most altarpieces of the 'Madonna of Humility' originally stood on altars in convent churches." ${ }^{427}$ We know, for example, the patrons of Andrea di Bartolo's small devotional Madonna lactans panels were women. While Giovanni Dominici saw to the distribution of the paintings in the Venetian Dominican convent

\footnotetext{
${ }^{423}$ van Os, Sienese Altarpieces, vol. 2, 75.

424 Taddeo di Bartolo's Budapest altarpiece exemplifies Christ's eucharistic invitation as he pauses and holds his mother's breast, looking directly at the viewer, as discussed in the previous chapter. When coupled with Mary's direct gaze, an intercessory meaning is also possible. For further discussion on the the Madonna lactans imagery as having an intercessory function see the last section of this chapter.

${ }^{425}$ van Os, Sienese Altarpieces, vol.2, 76.

${ }^{426}$ van Os, Sienese Altarpieces, vol.2, 84.

${ }^{427}$ van Os, Sienese Altarpieces, vol.2, 85.
} 
discussed above, the Dominican coffers paid for them. And furthermore, although the tiny figure of the praying nun in the bottom corner of the panel in Washington underscores its devotional function, her location and posture are traditionally reserved for patrons in Renaissance painting. ${ }^{428}$

All things considered, evidence concerning the image in convent life points to an appreciable presence. More than an iconographically pleasing picture, it functioned as a devotional conduit between the viewer and the divine, calling to mind Scriptural passages linking God's love to feeding, the provision of bodily food to the eternal life that Christ promised. It established an intimate reciprocal relationship suggested by the visual imitatio Mariae between Christ and devotee, devotee and Christ. The intense bond of unity with God involved not just a desire to be loved by him but that perfect act of charity, which is for us, in turn to love and to serve. We shall scrutinize how this devotion was manifest in the Madonna lactans image in greater detail below.

\section{Suor Plautilla Nelli}

We know of three women who rendered Madonna lactans images before the seventeenth century: Suor Plautilla Nelli, Sofonisba Anguissola, and Barbara Longhi. ${ }^{429}$ Suor Plautilla Nelli’s exquisite drawing, entitled Seated Madonna Nursing, has not been studied elsewhere (fig. 4. 12). Recently restored, it resides in the Gabinetto dei Disegni e Stampe degli Uffizi (GDSU) in Florence. While Suor Plautilla Nelli (ca.1523 - 1588)

\footnotetext{
${ }^{428}$ See for example, Masaccio's The Holy Trinity with the Virgin, St. John and Two Donors, 1425, Santa Maria Novella, Florence.

${ }^{429}$ For an essay on Sofonisba Anguissola's painting Madonna Nursing her Child, see Naomi Yavneh, "To Bare or Not to Bare: Sofonisba Anguissola's Nursing Madonna and the Womanly Art of Breastfeeding," in Maternal Measures: Figuring Caregiving in the Early Modern Period, eds., Naomi Miller and Naomi Yavneh (Burlington, VT, Ashgate, 2000), 65-81. For an examination of Barbara Longhi's Madonna lactans motif see Serena Simoni, "Una Nuova 'Madonna del Latte' di Barbara Longhi," Romagna arte e storia, vol. 24, no. 71 (2004), 105-112.
} 
falls slightly later than the chronology of this study, her drawing presents a unique case. It is rare indeed - perhaps otherwise unknown - for a nun to have rendered the Madonna lactans image, and it appears she made the drawing for her own edification. It was likely an image meant for private devotional viewing because the subject was proscribed. Nelli drew the motif at some peril, based upon the Savonarolan spirituality embraced by her Dominican convent, Santa Caterina da Siena - once located on the north side of Piazza San Marco in Florence. Savonarola had famously decried immodest dress and vehemently warned artists about the Virgin Mary's apparel. Savonarola's warnings about the Virgin's dress were heeded in Nelli's large public commissions, yet she disregarded them in her Seated Madonna Nursing drawing. Recall however, the effect the Madonna lactans image had upon nuns' devotion, as an inspiration for imitating Mary. We have seen nuns make use of the image to both stimulate and record devotion and intimacy with Christ. Therefore, despite her presumed loyalty to Savonarola's teachings, the image's existence raises questions. Examining Suor Nelli's background, the convent milieu in which she lived, her Savonarolan ties, her artistic influences, and others of her works, we can establish a basis for understanding Nelli's Seated Madonna Nursing drawing and perhaps unravel the mystery of why she made it.

Nelli is Florence's first acknowledged woman painter, yet she was largely overlooked by historians until recently. ${ }^{430}$ Vasari's discussion of her in his 1568 second edition of the Lives of the Most Excellent Painters, Sculptors, and Architects placed her in an elite class - one of the few women artists he mentioned. Vasari devoted more words to her than to history's better known Sofonisba Anguissola. Moreover he highlighted

\footnotetext{
${ }^{430}$ See n. 30 and 31 above.
} 
more works by Nelli than any other woman artist, and it is Vasari's account which still provides the best information regarding her work as an artist. $^{431}$ Vasari composed his biography of her while she was the prioress of her convent, Santa Caterina da Siena.

At the age of fourteen, Pulisena Margherita Nelli (the future Suor Plautilla) joined her older sister Costanza, called Suor Petronilla, at the convent of Santa Caterina da Siena. Eight years earlier their mother had died, when Pulisena was only six and Costanza nine. They grew up in the San Felice parish of Florence's Oltrarno district, and their father and uncle are identified as "mercers" (merciai) who sold items associated with fabrics and sewing. ${ }^{432}$ It is unclear whether the two sisters had any formal training before entering the convent, but they flowered under the Dominican nuns' instruction, both proving to be adroit scribes and Suor Plautilla a skilled artist. The elder sister is known for her transcription of Fra Girolamo Savonarola's biography, and Suor Plautilla inherited a copy of it. ${ }^{433}$ Nelli added a colophon to her inherited copy, honoring her sister's memory and identifying herself as "paintress" - "dipintora" after her signature. 434 Santa Caterina da Siena enjoyed the reputation of supporting an active art workshop, producing competent nun-artists for generations, and it was in that milieu that Nelli flourished as an artist and mentor to other nun-artists.

One of the better sixteenth-century sources on Nelli was written by Serafino Razzi in 1596 , who lavishly praised the many nun-artists at Santa Caterina, naming six as

\footnotetext{
${ }^{431}$ GiorgioVasari, Lives of the Painters, Sculptors, and Architects, trans. Gaston du C. de Vere, vol. 1 (New York: Alfred A. Knopf, 1996), 858 - 859.

${ }^{432}$ Catherine Turrill, "Nuns' Stories: Suor Plautilla Nelli, Madre Pittora, and Her Compagne in the Convent of Santa Caterina da Siena," in Plautilla Nelli (2008), 10.

${ }^{433}$ Firenze, Biblioteca Riccardiana, Moreniana, Monoscritto Moreni 219. The biography is virtually identical to La vita del Beato Jeronimo Savonarola scritta da un anonimo del secolo XVI e già attribuita a fra Pacifico Burlamacchi, published by P. Ginori Conti in Florence, 1937. Jonathan K. Nelson, "Introduction" in Suor Plautilla Nelli (2000), 4 n. 4.

${ }^{434}$ Turrill,"Nuns' Stories," 13.
} 
disciples of Suor Plautilla. ${ }^{435}$ Catherine Turrill identified twelve more nun-artists from the convent's extant account books and records. In addition to the eighteen nuns for whom Turrill found evidence of artistic activity, references to other anonymous artists exist. ${ }^{436}$ The sale of miniatures, manuscript illuminations, sculptures of "terracotta angels, Madonnas, and other saints," and painted canvases and panels helped support the convent. ${ }^{437}$ Convent records report the even greater breadth of artistic output. Hundreds of humble images in paper, plaster, papier-mâché, painted candles, and liturgical items such as altar frontals are counted among the convent's production. ${ }^{438}$ Santa Caterina's artistic output was truly unique in the "number and significance" (numero e valor) according to nineteenth-century Dominican historian Vincenzo Marchese. Its production was unrivaled in all of Italy, and no other religious community of men or women could count as many painters and sculptors in the sixteenth and seventeenth centuries. ${ }^{439}$ In those years, the account books attest to the healthy contribution da dipinture made to convent coffers. Vasari cast further light on this picture by naming Nelli's clients. Among them were monasteries, churches, convent churches, and male and female private patrons. Of her output he wrote, "In the houses of gentlemen throughout Florence there are so many pictures, that it would be tedious to speak of them all.,"440 Convent records concur. Clearly, the convent's creative atmosphere provided fertile soil from which Nelli grew as an artist.

\footnotetext{
${ }^{435}$ Serafino Razzi, Istoria degli huomini illustri, cosi nelle prelature, come nelle dottrine, del sacro ordine de gli predicatori (Lucca : per il Busdrago, 1596), a portion of which is translated by Dorothea Barrett in Plautilla Nelli (2008), 135-136.

${ }^{436}$ Catherine Turrill, "Compagnie and Discepole: The Presence of Other Women Artists at Santa Caterina da Siena," in Suor Plautilla Nelli (2000), 89-90.

${ }^{437}$ Razzi, 135-136.

${ }^{438}$ Turrill,"Compagnie and Discepole," 84.

${ }^{439}$ Turrill,"Compagnie and Discepole," 85. See also Gary M. Radke, "The Nun Artist in Historical Context," in Suor Plautilla Nelli (2000), 13 - 17.

${ }^{440}$ Vasari, (1996) 859.
} 
The other strong current running through the convent was its Savonarolan spirituality. The convent's founder, Suor Lucia (née Camilla) Bartolini Rucellai (1465 1520), was a devout follower of Savonarola, ${ }^{441}$ and Santa Caterina remained one of the most important centers of female Savonarolan spirituality in the years following the friar's execution in 1498. ${ }^{442}$ The Piagnoni, a galvanized branch of Savonarolan supporters, provided Santa Caterina with endowments and alms. Additionally, powerful members of the Piagnoni placed their own daughters in the convent, the better to monopolize its lay functions, continuing the work begun by Savonarola. ${ }^{443}$

In fact, one cannot read about Plautilla Nelli without noting Savonarola's influence on her artworks at every turn of the page. ${ }^{444}$ Andrea Muzzi, who has studied that influence at length, made the point that her art reflected a Savonarolan "ideological example of a religious in action." ${ }^{445}$ Nelli exemplified her adherence to Savonarolan ideas in her art when she painted Pentecost, in which she included Mary Magdalene. The Magdalene's traditional accoutrement of an ointment jar is in evidence. Muzzi observed, “This motif was dear to the painters close to Savonarola's ideas: the Magdalene's jar, according to the preacher, keeps the love of God warm, while earthly affections fade away."446 The friar's sermons resolutely steered the faithful away from temporal distractions in favor of the spiritual. Savonarola promoted drawing and painting by

\footnotetext{
${ }^{441}$ Turrill, "Nuns' Stories," 9.

${ }^{442}$ Lorenzo Polizzotto, The Elect Nation: The Savonarolan Movement in Florence 1495 - 1545 (Oxford: The Clarendon Press, 1994), 189.

${ }^{443}$ Polizzotto, $189-190$.

${ }^{444}$ For example: Andrea Muzzi, “The Artistic Training and Savonarolan Ideas of Plautilla Nelli," in Plautilla Nelli (2008) 28-44. Andrea Muzzi, “The Formation of Plautilla Nelli 'dipintora': Artistic 'Dilettantismo' and Savonarola's Ideas in the Convent,' in Suor Plautilla Nelli (2000), 31-44. Jane Fortune with Linda Falcone, Invisible Women (Florence: Collana The Florentine Press, 2009), 33. Turrill, "Compagnie and Discepole," 83. Turrill, "Nuns' Stories," 9.

${ }^{445}$ Muzzi, "The Formation of Plautilla Nelli," 35.

${ }^{446}$ Muzzi, "The Formation of Plautilla Nelli," 43.
} 
religious women as a way to avoid sloth, and his sermons and correspondence reflect his dogmatic views about religious art. His opinions were frequently didactic and never vague. For example, in a letter to Maddalena Pico della Mirandola, a nun with whom the friar corresponded regularly, he wrote that a cell should be adorned with "simple figures. ${ }^{\text {"447 }}$ His pronouncement about the form religious imagery should take in the private domain of the convent cell highlights the degree to which he was dictatorial about visual art, for his concern for simplicity extended to his preoccupation with virtue. ${ }^{448}$ That Savonarola's sermons (and the subsequent Piagnoni lectures) dealt with modesty, especially relative to female dress, is well-known. In a series of sermons on Amos from 1496, Savonarola lectured vehemently to artists against immodesty in the Virgin's attire in their paintings.

Do you think the Virgin Mary would go about dressed as you paint her? I say to you that she was dressed like a poor girl, simple, and covered up so that you could hardly see her face [emphasis added]. St. Elizabeth too was simply dressed. You would do a very good deed if you would erase those figures of yours painted to resemble immoral women. You show the Virgin Mary dressed like a prostitute. Now indeed is the worship of God destroyed! $!^{49}$

The fiery orator left no room for uncertainty. He stated his objection in the strongest and most jarring terms, analogizing dressing the Virgin improperly to painting a prostitute's attire. Another translation this passage uses the word "whore." 450

As intimated at the beginning of this chapter, among Madonna image-types the danger of the Virgin being construed as a prostitute was greatest for the Madonna

\footnotetext{
${ }^{447}$ Andrea Muzzi, "The Artistic Training and Savonarolan Ideas of Plautilla Nelli," 30.

${ }^{448}$ Ronald M. Steinberg, "The Visual Arts in Savonarola's Sermons," in Fra Girolamo Savonarola, Florentine Art, and Renaissance Historiography (Athens, Oh: Ohio University Press, 1997), 45-57.

${ }^{449}$ Quoted from the sermon preached on the Saturday after the second Sunday of Lent in the series on Amos and Zachariah in Marcia B. Hall, "Savonarola's Preaching and the Patronage of Art," in Christianity and the Renaissance: Imagery and Religious Imagination in the Quattrocento, eds. Timothy Verdon and John Henderson, (Syracuse, NY: Syracuse University Press, 1990), 516, n. 19.

${ }^{450}$ Gilbert, Italian Art, 157-58.
} 
lactans. In such images the Virgin's neckline is necessarily low or there is a slit in her garment, in order to expose her breast. It is a far cry from being so covered that "you could hardly see her face." Savonarola's words leave little doubt that for him, the nursing Madonna was the most offensive motif in the corpus of Marian art. Furthermore the consequences were no small matter. Destruction of something as sacred as the "worship of God" was the product of such an odious image. Yet, despite her faithfulness to his teachings, Suor Plautilla Nelli made a drawing of the Seated Madonna Nursing (fig. 4.11). Nelli adhered to Savonarola's dictates in her paintings of the Virgin, but not in this drawing.

Only three paintings by Nelli have been authenticated. ${ }^{451}$ Two feature the Virgin Mary: The Lamentation and Pentecost. A comparison of the Virgin's dress in the Seated Madonna Nursing drawing with her clothing in the two paintings reveals a far more exposed nursing Madonna. In the Lamentation (fig. 4.13 and 4.14) the Virgin is covered "so that you could hardly see her face," as the preacher directed. The same is true of the Virgin in the Pentecost (fig. 4.15). In both paintings the Virgin wears a wimple and a veil, the combination of which covers up to the area under her chin and the area all around her face and forehead. And in the Pentecost her blue mantle is pulled over her head. In contrast, the neckline in the drawing is boldly scooped, exposing part of Mary's shoulder and a substantial portion of her bare décolleté. Her right breast is almost completely revealed as the Christ Child tugs down on the dress's bodice. At the same time, both of the Child's hands caress the breast, and the Virgin's left hand holds up her breast to position it for feeding. The combination of the three hands and the Virgin's

\footnotetext{
${ }^{451}$ Catherine Turrill, "Appendix 2, List of Paintings Attributed to Nelli," in Plautilla Nelli (2008), 118 -
} 119. 
gaze, which is aimed at her breast and her Child, directs the viewer's attention to that area. In the Lamentation and Pentecost paintings the Virgin's demure downward gaze and modest hand gestures present a marked contrast to the drawing's warm, intimate mood. The two paintings are narrative scenes in which the objective, to tell the respective stories, is helped by her gestures and glances. In both paintings the Virgin's modesty is explicit and follows Savonarolan dictates. On the other hand, the drawing is surely a devotional piece, meant for the artist's gaze alone. In the name of personal devotion, she took certain liberties with the composition, daring to render a freer expression of the same maternal love so cherished by nuns we have studied.

Nelli's approach to the drawing went against the Savonarolan ideology in pursuit of her own devotion. Based upon what we know about nuns' devotion as brides of Christ, it is possible Nelli made this image for her own edification. There is no way to be certain. However, additional evidence will rule out some possible reasons to explain its appearance within her recognized oeuvre.

Vasari mentioned a number of paintings by Nelli that have not been found. The Seated Madonna Nursing drawing may be the preparatory sketch for a missing painting, yet at present it cannot be connected with any known work. Of the three paintings of the Madonna and Child that Vasari described, we can almost certainly rule out a painting of the "Magi adoring Jesus [which] is much extolled." were never conflated, and it certainly would have been very unusual if Nelli introduced such a combination. According to Vasari, who was a contemporary of Suor Nelli's and is our best primary source about her, originality was not her forte. He declared her to be a

\footnotetext{
${ }^{452}$ Vasari, (1996), 859.
} 
diligent imitator. He wrote, "She, beginning little by little to draw and to imitate in colors pictures and paintings by excellent masters, has executed some works with such diligence, that she has caused the craftsmen to marvel. . . The best works from her hand are those that she has copied from others. ${ }^{, 453}$ Fra Serafino Razzi is another literary source for Nelli's work. He echoed the Vasarian assertion that her best works were "those she copied from others. ${ }^{454}$

Another lost painting which would have included the Madonna and Child is a Nativity. Vasari declared it was copied "from one which Bronzino once painted for Filippo Salviati. ${ }^{\not 45}$ Filippo’s son Antonio was a benefactor of Santa Caterina and, according to Catherine Turrill, he allowed other artists to copy the work. ${ }^{456}$ The Bronzino is now in the Szépmüvészeti Múzeum, Budapest (fig. 4.16). In the Budapest composition the Virgin kneels in the center of the painting adoring the Christ Child, who lies on a marble slab close to the ground with the shepherds surrounding him. Mary is not holding the Christ Child as in the Seated Madonna Nursing drawing, and the compositions are completely different; hence it is safe to say the drawing was not a preparatory sketch for the lost Nativity painting either.

A third contender described by Vasari is of "Our Lady with the Child in her arms, S. Thomas, S. Augustine, S. Mary Magdalene, S. Catherine of Siena, S. Agnese, S. Catherine the Martyr, and S. Lucia.. ${ }^{457}$ Vasari situated this large altarpiece in the choir

\footnotetext{
${ }^{453}$ Vasari, (1996), 859. The term "craftsmen" is used in this edition's translation. Vasari used the word artefice. The translator's note declared this the "nearest to expressing Vasari's idea of the 'artefice' as a practical workman.” See Vasari, (2006), xxi.

${ }_{454}$ Razzi, 135.

${ }^{455}$ Vasari (1996), 859.

${ }^{456}$ Turrill, "Paintings Attributed to Nelli," 121.

${ }^{457}$ Vasari (1996), 859.
} 
of the Convent of S. Lucia in Pistoia. It probably was the important "quadro di Santa Lucia," for which Nelli reported compensation in March of $1559 .^{458}$ Also lost, it is impossible to say whether "Our Lady with the Child in her arms" was seated and nursing as in our drawing. In the two authenticated, large commissions we have previously examined, the Virgin is covered quite completely (figs. $4.13-4.15$ ). If these are indicative of Nelli's approach to depicting Mary in large, public paintings, it is likely that the Santa Lucia altarpiece did not include a Madonna suckling her Son. We may never know for certain, however. What we do know for certain is that the two large, extant, paintings portray Mary dressed with Savonarolan modesty, as if the preacher had painted them himself.

Let us turn to what is certain about the drawing. Of the nine authenticated drawings by Plautilla Nelli ${ }^{459}$ in the GDSU, the Seated Madonna Nursing is the most fully elaborated. There are just twelve drawings in the Uffizi collection under the heading "Suor Plautilla Nelli," and an examination of these revealed that the Seated Madonna Nursing is the most finished and looks least like an exercise or sketch. The pyramidal composition has a monumentality that belies its small size. The description of form beneath the drapery is defined with anatomical accuracy, although, a few areas come across as awkward. In particular, the Virgin's left foot is not defined beneath the pool of drapery on the floor at all, and her right foot is drawn at an unnatural angle. But, for the most part the drawing was executed with a sure hand and delicate line quality. At the same time there is a robust and weighted quality to both figures. Both the Child's and

\footnotetext{
458 Turrill, "Paintings Attributed to Nelli," 124.

${ }^{459}$ Maria Faietti, Appendix 1 “'In the Shadow of the Friar': The Uffizi Drawings Attributed to Plautilla Nelli," in Plautilla Nelli (2008), 99-117. Doubt about attribution has been recently cast on three of the GDSU drawings.
} 
Mary's faces are executed with classical features. The soft chiaroscuro defines the figures' contours convincingly. Lips, eyelids, cheeks, and chins are defined by a deft use of light and shadow. The drawing is finished with a sepia wash and white highlights. The Virgin's veil is subtly diaphanous and falls from the top of her head to the floor, covering her back and reinforcing the pyramidal shape. No area is unresolved; it is, for all appearances, a fully finished composition.

All the other drawings by Nelli appear to be exercises. For example, in Kneeling Woman there is a visible pentimento in the hand area, and the head is a ghost of linear form. Likewise Drapery Study is reminiscent of drawing-class exercises - a cropped study of a figure's lap draped in nicely rendered folds of cloth. Partial Study of Michelangelo's Risen Christ is another such example (fig. 4.17). It too is unfinished and appears to be a means for the artist to study male features, which were unavailable to Nelli in the form of a live model. Next to the Seated Madonna Nursing, the closest to a finished composition is the striking Head and Shoulders of a Young Woman. However, it has a noticeable pentimento around the shoulder of the subject's dress. This piece might well have been a study for one or more of the individuals in Nelli's religious paintings. Thus, if the Seated Madonna Nursing drawing stands out as a finished piece and indeed was not meant to serve as a preparatory draft for a painting, then it demands an exploration of the resources she may have tapped for its impetus and inspiration.

Suor Nelli seems to have had a great number of drawings by fra Bartolommeo at her disposal, which she studied in lieu of live models. Vasari provides some evidence for this. He lamented the fact that as a woman, Nelli did not have access to live models. "[S]he shows that she would have done marvelous things if she would have enjoyed, as 
men do, advantages for studying, devoting herself to drawing, and copying living and natural objects. ${ }^{, 460}$ Because live models were usually unavailable to her, Nelli's sources were necessarily other artists' works. Vasari's text about fra Bartolommeo in Lives indicates that a large corpus of Bartolommeo's drawings was transferred from San Marco, where he had spent his vocational life, to Santa Caterina. Vasari recounted, “... [T] he greater part [of his drawings] are now in the Monastery of S. Caterina da Siena on the Piazza di S. Marco, in the possession of a nun who paints, and of whom record will be made in the proper place." ${ }^{461}$ In 1727 a large number of fra Bartolommeo's drawings were purchased from the Santa Caterina Convent and sold to Niccolò Gabburri, Director of the Accademia dell'Arte del Disegno in Florence. ${ }^{462}$ Further evidence for Gaburri's possession of the corpus of drawings can be found in the 1728 text Notizie dei professori del disegno da Cimabue in qua by Filippo Baldinucci, published posthumously and edited by his son Francesco. There it is noted that the Bartolommeo drawings, which Vasari strongly implied had been in Nelli's possession, were "presently in the hands of Cav. Gabburri in Florence and are about five hundred in number." ${ }^{463}$ The drawings came into the possession of the Boymans Museum Foundation in Rotterdam in the twentieth century. This vast corpus of drawings provided a basis for the study of Nelli, and although Bartolommeo died six years before Nelli was born, in essence he was her teacher.

\footnotetext{
${ }^{460}$ Vasari (1996), 859.

${ }^{461}$ Vasari (1996), 679.

${ }^{462}$ Chris Fischer, Fra Bartolommeo: Master Draughtsman of the High Renaissance. A Selection from the Rotterdam Albums and Landscape Drawings from Various Collections (Rotterdam: Museum Boymans-van Beuningen, 1990), 18-19. Faietti, 101.

${ }^{463}$ Quoted in Faietti, 101.
} 
Bartolommeo's Lamentation with Saints Peter and Paul in the Galleria Palatina has been compared to Nelli's painting of the same subject, and certainly it is difficult to ignore the friar's influence. ${ }^{464}$ In line with this observation, in her 1938 book, Giovanna Pierattini surmised that the head of Nelli's nursing Madonna was derived from a Bartolommeo drawing. She wrote, "The composition marked n. 249 seems good to me. It represents the Virgin nursing the Christ Child, The head of the Madonna seems to me to be a copy by fra Bartolommeo (Uffizi, 473, F.). ${ }^{465}$ The Uffizi Bartolommeo to which Pierattini referred is a study of a head seen from a different angle than Nelli's Madonna. ${ }^{466}$ However, Bartolommeo's Study for the Head of the Virgin, now in the Rotterdam collection, provides a closer comparison (fig. 4.18). The similarity between the Rotterdam Bartolommeo study and the Virgin's head in Nelli's Seated Madonna Nursing is palpable (fig. 4.19). Both heads are inclined at the same angle and the execution of the features and tender, maternal expressions are alike. Chris Fischer noted that the model was the same for both Bartolommeo's Uffizi and Rotterdam studies. For Nelli, the model was the Rotterdam drawing. And going one step further, the combination of the Bartolommeo Study for the Head of the Virgin and yet another Bartolommeo drawing may have been Nelli's inspiration for her nursing Madonna. A Rotterdam Bartolommeo drawing entitled Study of a Woman Nursing a Baby bares a thematic resemblance (fig. 4.20). Fischer deemed it an unlikely prototype for a specifically Virgo lactans image, reasoning that the informal visual angle precluded it

\footnotetext{
${ }^{464}$ Magnolia Scudieri, “The History, Sources, and Restoration of Plautilla Nelli's Lamentation" in Plautilla Nelli (2008), 60-65. Jonathan K. Nelson, Suor Plautilla Nelli (2000), 5.

${ }^{465}$ "Di quello segnato $n$. 249 la composizione mi sembra buona, rappresenta la Vergine che allatta il Figlio. La testa della Madonna mi sembra copia di quella di fra Bartolommeo.” Pierattini, 38 - 39.

${ }^{466}$ GDSU, Florence, 473 E: black chalk, yellow highlights. Fischer, 217.
} 
from it representing a religious subject. ${ }^{467}$ And to be sure, Nelli's frontal pyramidal composition bestows a formality lacking in the Bartolommeo drawing. Furthermore, the Virgin's long veil and the Christ Child's gaze at the viewer signify that Nelli's is a Madonna and Child, a religious theme rather than a secular one such as Bartolommeo drew. To summarize, it is difficult to ignore the debt Nelli owed to Bartolommeo's nearly identical Study for the Head of the Virgin. And she may have seen his drawing of a nursing mother and altered it to a more formal, more religious version. Why would Nelli make a sacred version of Bartolommeo's secular study? Yet one must ask why is her Seated Madonna Nursing so fully elaborated compared to her other drawings? Moreover, in light of her finished paintings of the Virgin, which reflect Savonarolan decorum - in posture, dress, and gestures - why would she draw a Madonna motif so reviled by Savonarolan spirituality? I suspect she made it for her eyes only - for private devotion.

As a Dominican nun, Nelli was a member of a community - an interpretive community, as described in our Introduction. Her community had a history of devotion to the nursing Madonna. Giovanni Dominici, the influential Dominican friar and prolific writer, alluded to earlier, left behind volumes of instructional texts. Recall that in 1403 he advised that the nursing Madonna was a good image to have in his Rule for the Management for Family Care: "The Virgin Mary is good to have, one with the child on her arm. A good figure would be Jesus suckling." ${ }^{\text {"468 }}$ And it was he who saw to the installation of an image of the Madonna lactans in each nun's cell in the Dominican

\footnotetext{
${ }^{467}$ Fischer, 334.

${ }^{468}$ Giovanni Dominici, Rule for the Management of Family Care, Part IV, (1403) quoted in Gilbert, Italian Art, 145.
} 
convent of Corpus Domini in Venice on the day it was consecrated in 1394. At least one of those Madonna lactans images included a Dominican nun in the bottom right corner cast in dual roles as patron and devotee (fig. 4.6). The Nelli drawing may have served the same purpose in the Tuscan Dominican convent about a century and a half later.

While it is impossible to prove Nelli's desire to meditate before the image of the Seated Madonna Nursing, we can point to some facts to back the hypothesis that she made the image for her own personal use. First, as elaborated previously, there is data to support nun-devotion to this Marian image-type. Second, Nelli's drawing is a finished composition, implying that she cared about it and went to special lengths to complete it. Third, it is not a prototype for any extant painting, and it appears not to have been a sketch for a lost painting. Fourth, one might suppose that her impulse to meditate upon the image in private superseded the risk of going against Savonarola's directions. And fifth, ironically, the seeds of a desire to imitate Mary (imitatio Mariae) in multiple roles, as other nuns did, may have been sown through a different Savonarolan sermon.

On Assumption Day in 1495, Savonarola preached about honoring Mary in the multiple roles of daughter, bride, and mother of God. The sermon, Compendio di revelatione was published the following year. The friar spoke of his vision of a heavenly crown which had twelve hearts and twelve ribbons bearing inscriptions of the Virgin's unique mystical "privileges." The preacher defined the "privileges," explaining that the Virgin was: "Sposa di Dio Padre vera, because God the Father and she have one and the same Son... [and] Madre del suo padre, because Jesus Christ was the Son and is God 
the Creator of the Universe, who created her." ${ }^{469}$ A woodcut image of this allegorical crown illustrates the sermon's message (fig. 4.21) ${ }^{470}$ Hatfield explained that the crown symbolizes prayers said to Mary, asking her to pray (to God) for us: "The 'privileges' are really the invocations in twelve supplications to Mary to pray for us; indeed the whole crown is effectively an elaborate set of prayers." ${ }^{471}$ The crown's prayers were later recited by Savonarolan followers. People were encouraged to recite the corona or coronella. ${ }^{472}$ In the same sermon the preacher explored the twelfth chapter of Revelation, connecting the glory of Mary with the imminent coming of Christ on earth. "A great sign appeared in the sky, a woman clothed with the sun, with the moon under her feet, and on her head a crown of twelve stars. She was with child and wailed aloud in pain as she labored to give birth (Revelation, 12.1 - 2)." As we have discovered, these Marian themes were poignant for nuns who embraced Marian roles as they entered the convent. Mary's privileged positions as spouse and mother of God, outlined by Savonarola in his sermon and immortalized in the woodcut, would have encouraged nuns to envision themselves in those roles too, as demonstrated previously. The Madonna lactans motif was the emblematic image before which nuns meditated on imitating and honoring Mary, and the existence of the drawing is evidence, at least in some measure, of Nelli's devotion to the theme. If scholars are correct that Suor Plautilla Nelli otherwise followed Savonarola's compelling dictates, this study suggests she must have been at least

\footnotetext{
${ }^{469}$ Girolamo Savonarola, Compendio di revelatione, Florence, (Francesco Bonaccorsi) 1496, fols 30r-6v, quoted in Rab Hatfield, "Botticelli's Mystic Nativity, Savonarola and the Millennium," Journal of the Warburg and Courtauld Institutes, 58 (1995), 94.

${ }^{470}$ Rab Hatfield of Syracuse University, Florence, discovered the woodcut image. He realized the sermon's words corresponded exactly to the inscriptions on the ribbons held by the twelve angels in the upper register of Botticelli's Mystic Nativity

${ }^{471}$ Hatfield, 95.

${ }^{472}$ Hatfield, 96.
} 
somewhat ambivalent along that path. The existence of the forbidden nursing Marian icon demonstrates that her devotion to Mary prevailed over her devotion to the friar.

There is evidence of other instances as well in which she did not follow Savonarolan sentiments slavishly. A look at Vasari's and Savonarola's texts is revealing. Vasari's last line about Nelli is a flattering description of some of her religious paintings' figures.

In the faces of women in some of her works she has portrayed Madonna Costanza de' Doni, who has been in our time an unexampled pattern of beauty and dignity; painting her so well, that it is impossible to expect more from a woman, who for reasons stated above, has had no great practice in her art. ${ }^{473}$

Savonarola preached to painters specifically against using recognizable models for religious paintings, warning them that it dishonored God and caused scandals.

The images of your Gods are the images and likenesses of the figures you have painted in churches, and then the young men go around saying to this girl and to that girl, "That girl is the Magdalene, that other girl is St. John," because you have the figures in churches painted in the likeness of this woman or that other one, which is ill done and in great dishonor of what is God's. You painters do an ill thing; if you knew what I know and the scandal it produces you would not paint them." 474

The admonition was clearly directed at painters. Using someone well known as a model was forbidden, and yet Nelli's sometime model was so recognizable that Vasari named her. Nelli appears to have been loyal to Savonarola's directives when it suited her purposes. But if the nun-artist had access to a good-looking model, she must have asked her to sit for her. Live models were scarce. The ability to identify Nelli's model does not indicate an egregious religious infraction; it simply points to Nelli's willingness to accommodate her artistic needs and calls into question the degree of her support of the

\footnotetext{
${ }^{473}$ Vasari (1996), 859.

474 Savonarola, from Sermons on Amos, 1496, quoted in Gilbert, Italian Art, 157.
} 
friar's directives. I suggest that she may not have been the faithful Savonarola follower that history remembers.

In addition, scholars often point to Nelli's prized possession, a biography of Savonarola and Nelli's inscription in it, as proof of her ardent devotion to his teachings. ${ }^{475}$ This inscription is the only extant example of Nelli's own words written in her own hand. The Life of Savonarola was penned by Suor Petronilla, Plautilla's beloved sister and fellow Dominican nun. Petronilla bequeathed the book to her younger sister around 1560 before she died. The inscription reads:

This book belongs to the convent of Santa Caterina da Siena in Florence and is the possession of Suor Plautilla Nelli nun in this convent, sister of the above mentioned Suor Petronilla and a painter, and I beg all those persons into whose hands it should come to return it because she holds it very dear for the preciousness of the book and for the memory of her sister who has passed on to a better life. ${ }^{476}$

The first part of the inscription is a plea for the book to be returned should it become lost. The second part gives two reasons for the plea: "because of the preciousness of the book and for the memory of her sister who has passed on ..." From this, it is clear Plautilla valued the book because it was her sister's. It was in her sister's handwriting, and it was a special inheritance. The motive "for memory of her sister" is clearly stated and must have been acutely felt by the grieving sibling. Whether the book was precious because it contained the life story of her moral compass, Fra Savonarola, or for another reason is not clear. "Preciousness of the book," after all, could have meant it was treasured because of its high material value. The inscription itself does not unambiguously imply Nelli's Savonarolan devotion.

\footnotetext{
${ }^{475}$ Muzzi, "The Formation of Plautilla Nelli," 42.

${ }^{476}$ Quoted in Muzzi, "The Formation of Plautilla Nelli," 42.
} 
Nelli heeded Savonarola's warnings about the Virgin's dress in her large public commissions but not in the small drawing of the nursing Virgin. We know that the convent embraced Savonarolan spirituality. Nelli was three times voted prioress of the convent, which is testimony to her ability to lead and to her perceived spirituality. It is not my suggestion that she conducted herself in an overtly counter-Savonarolan manner or that she purposely rebelled against the friar's or the Piagnoni's teachings. But scrutiny of anyone's behavior is likely to fall short where adherence to a strict code of conduct is concerned. Devotional prayer was a principal occupation for members of religious communities, and its fervor could have driven creative impulses usually held in check for public consumption. The Piagnoni, outspoken supporters of Savonarolan doctrine, were benefactors of Santa Caterina with daughters among the convent's ranks. Nelli would not have rendered a Virgin so uncovered as she is in the drawing in question for public viewing, biting the hands that fed her. Thus, the drawing was a visual aid for her private prayer.

Nuns' devotional practices before Madonna lactans images were a channel for attaining intimacy and a connection with the divine. Imitating Mary was at the heart of it. All of the warmth and maternal intimacy lacking in the Marys of the Pentecost and the Lamentation paintings can be found in Nelli's drawing. The prioress created for herself a Mary she could emulate. Scriptural passages about Christ's love and feeding would have been familiar to Nelli, and when she meditated on those passages, the nursing image was the desired visual aid. Like Blessed Paula of Camalduli and the nuns at Blois who were devastated by the removal of their nursing Madonna painting, Suor Plautilla likely sought the connection to the Virgin Mary and communion with the divine that the image 
engendered. The anonymous nun at St. Walburg inscribed Christ's plea to be fed on the panel commemorating her sanctification ceremony. Her Consecration of Virgins includes Christ's imperative, "Suckle me," and with it, the promise of a reward. For brides of Christ, this image was so important because it prompted their imitatio Mariae, establishing an intimate reciprocal relationship between devotee and Christ, Christ and devotee. Unlike her public representations of Mary, the nursing Mary of the drawing was worthy of the prioress's imitation. In it the Virgin gazes with tenderness at her Child and the source of his food, her own breast. One of her hands holds up his head and her other hand props up her breast for him. The Christ Child looks out at the viewer. Compare Michelangelo's Madonna and Child, a drawing in the Casa Buonarroti collection from ca. 1525 (fig. 4.22). The nursing Virgin deliberately looks off in the distance as the Christ Child suckles. He is occupied solely with nursing, his face in profile all but hidden. It is significant that Michelangelo originally drew the Madonna's face in profile, her eyes cast down at her suckling Child, but changed his mind for the final drawing. ${ }^{477}$ Ultimately, his drawing is less intimate. Michelangelo's is a drawing of a mother nursing a hungry baby, and Nelli's is so much more. Hers is the embodiment of a nun's personal devotion to an ideal. If Nelli's spirituality was anything like the other nuns we have studied, from the same or other orders, then we can infer comparable devotional beliefs. Feeding Christ is an act of love, nourishing the Savior will be rewarded with eternity, and

\footnotetext{
${ }^{477}$ Pina Ragionieri, Casa Buonarroti, Milan: Mandadori Electa S.p.A., 2009, 46. Ragionieri states, "[T]he most notable correction on this sheet reveals that Michelangelo had originally drawn the Madonna's face in profile, with her eyes lowered to gaze down at the child. ..." Scholars have interpreted the purposeful denial of an emotional relationship between mother and child in Michelangelo's renditions of the nursing Madonna motif as the artist's psychological exploration of a void in his own mother-son relationship. The same distancing exists in his early relief, Madonna della Scala. It has also been suggested that the Virgin foresees Christ's inevitable Passion, the price of salvation, in her thoughtful outward gaze. Rona Goffen, "Mary's Motherhood According to Leonardo and Michelangelo," Artibus et Historiae 40, no. 20 (1999): 44 $-46$.
} 
the devotee is invited to be an active participant. Suor Plautilla Nelli was following Savonarola's encouragement for imitation of the Mother of God and prayer before images, but she did so on her terms. The breastfeeding theme was deplorable to Savonarola, yet indispensable to Nelli. She drew it and then kept it to herself. In this instance artist and devotee were likely one and the same person.

If the artist drew the image for her own edification, and if she could render the scene precisely to suit her needs, the composition is worth a second look, as a drawing created by someone very conscious of its function and its viewer. We previously recognized the tenderness revealed in the motherly caress and expression, hypothesizing Nelli wished to create a Virgin Mary to emulate. But what about the Christ Child? He makes eye contact with the viewer, inviting the devotee into the intimate scene. He is not yet eating. One of his hands rests on Mary's exposed breast, and the other rests above on her bare décolletage, creating a gestural frame around his mother's breast. Mary's left hand lies diagonally across her chest. Her fingers form the left boundary of that frame such that the breast becomes the focal point, calling attention to the source of nourishment and intervention. ${ }^{478}$ The Christ Child's inviting gaze and the gestures attract the viewer to the source. Hence, the composition is one of the strongest clues to the drawing's function.

In general, heightened awareness about function must have been uppermost in every Renaissance artist's mind. Pleasing the client prompted more work. Devotional artworks were commissioned by people who would engage with them in the manner of the era. A consideration of how other Renaissance artists' responded to their viewers'

\footnotetext{
${ }^{478}$ We shall address how Mary's breast is connected to mercy and intercession presently.
} 
use of devotional images will expand our understanding of their reception. While the Madonna lactans devotional image comprised a surprisingly varied set of signifiers, let us now examine a group of them that had something in common. We shall find that in a number of nursing Madonna paintings from the same time and locale, it appears that artists intentionally made viewers complicit in their very function.

\section{The Included Audience}

The iconography of the Christ Child directly engaging the viewer as in the Nelli drawing was not new. It had numerous historical prototypes. We see the Christ Child's dramatic turn of the head as early as the second or third century in the wall painting in the Roman Catacomb of Priscilla, which has been identified as the earliest representation of the suckling Child (fig. 2). ${ }^{479}$ The Christ Child's dynamic head-turn is repeated in many of the late thirteenth and fourteenth century Madonna lactans images. ${ }^{480}$ Millard Meiss maintained that the Christ Child's simultaneous posture of nursing and turning to look at the spectator developed more extensively in Siena than in any other place in Italy or Europe in the thirteenth and fourteenth centuries. ${ }^{481}$ Despite its antiquity, the pose is rarely seen in earlier examples, as the mother-child relationship tends to be more hieratic in the twelfth and thirteenth centuries, and as such distinctions endured into the Renaissance. ${ }^{482}$ This section seeks to refine our knowledge about how both male and female Renaissance viewers may have received images of the nursing Madonna while praying. The artworks themselves will illustrate that worshipers "took part" in

\footnotetext{
${ }^{479}$ Shorr, 68. Lasareff, 27. Meiss, Black Death, 147. That the painting may be the earliest surviving image of Mary and her Son, see Rubin, Mother of God, 25. See also the second leaf of the unpaginated color plate section in Rubin.

${ }^{480}$ Shorr, 69.

${ }^{481}$ Meiss, Black Death, 146.

${ }^{482}$ Shorr, 69.
} 
experiential viewing. Not only did Christ gaze directly at viewers, but the Virgin looks pointedly outward as well in many lactans images. Their gaze is an invitation to the devotee. Intercession and mercy are being offered to the spectator through the pantomime of Christ and Mary's gestures and glances. We shall consider several small paintings, suitable for private devotion, which were painted within approximately twentyfive years of each other and in the northern part of the Italian peninsula. Additionally, we shall consider the intercessory meaning in some larger images in which Christ and Mary appeal to God the Father, indicating their side wound and breast, respectively, as grounds for prayers to be granted to their faithful followers.

In Andrea Solario's Madonna with a Green Cushion the Virgin and Christ Child share a tender exchange as he nurses, and the naked Christ Child playfully grabs his own foot, as babies do (fig. 4.2). Mary wears a beatific expression as she gazes into her nursling's eyes; he returns the affectionate look. In another example, the Christ Child is up to more serious business. Ambrogio da Fossano's (called Bergognone) Christ Child is dressed and sitting up. He gazes directly out at the viewer (fig. 4. 23). The Solario painting depicts an intimate moment between the Virgin and her Child; the viewer is an onlooker, and the devotee is not included. Ambrogio's Mary and Jesus include the viewer quite deliberately. Here the Christ Child is not interested in nursing. The direction of his gaze is direct, pointed. He turns and addresses the viewer and his hand rests on his Mother's breast as if showing it to the viewer; he does not grab or hold the breast to position it for sucking. The combination of the gesture and the directed gaze (and the use of the lopsided anatomy) asserts the image's symbolic function. Christ presents his Mother to the viewer as the mother of us all, nurturer of us all. Mary's 
gesture and gaze contribute to this message as well. Her left hand holds Christ, and her right hand lies across her chest, pointing toward her exposed breast. Mary looks outward, and at first glance it appears she engages the devotee, too, but if we follow her eyes we notice that her gaze includes a wider audience. We realize the two figures together take in more than one devotee, and the viewer can count him or herself among the privileged faithful. In another Madonna and Child (this one is not a Madonna lactans) example by Ambrogio the dual gaze device is again unmistakably employed (fig. 4.24). Mary's and Christ's inclusive eye-contact, focused on more than one devotee, is striking. She is Mater omnium and Nutrix omnium, and the prize is a powerful, merciful intercessor. The merciful Mary and the mother-Son intercessory role will be discussed presently.

Another example is in the Vatican Museum. Giovanni di Pietro, called Lo Spagna, painted his Madonna del Latte between Saint Mary Magdalene and Saint Anthony of Padua in the early years of the sixteenth century (fig. 4.25). ${ }^{483}$ All four figures look in slightly different directions. It is reminiscent of a group photograph in which several photographers snapped the shutter at the same time, everyone looking into a different camera. Because of this Lo Spagna's painting also gives the impression that the subjects connect with an audience of multiple devotees. As a lone devotee meditated before it, such a worshiper would have felt that there were others behind him or her. The feeling that there were others sharing his or her burdens as well as devotions, and that Mary's intercessory power was available for all, must have been comforting. It functioned as group therapy of the age.

\footnotetext{
${ }^{483}$ Giovanni di Pietro is often referred to as Lo Spagna because he was born in Spain, but he spent most of his life in Italy.
} 
In the next three examples the Virgin's gaze is less open than the Christ Child's and in all of them Christ holds the viewer's attention through additional signals. The meaning is made apparent through the iconographic details. The first is by Luca Signorelli, who painted Madonna and Child in Glory with Angels in the 1480s, now in the Pinacoteca di Brera in Milan (fig. 4.26). ${ }^{484}$ In the painting the Christ Child sits in Mary's lap in a frontal pose and offers his Mother's breast to the spectator with both hands, his gaze aimed directly at the beholder. His hands are positioned around the breast as one would hold a prized gift. The blatant gesture is one of offering. It is as if the Christ Child is saying, "This is for you." Mary's hand points to her breast, indicating the offering as well. Beholders are brought into an intimate inner circle by the Child's direct gaze.

The same direct gaze and a new application of a familiar gesture is employed in a Marco d'Oggiono's Madonna del Latte, presently in the Auckland Art Gallery in New Zealand (fig. 4.27). In numerous nursing images we have seen the so-called scissor or $\mathrm{V}$ hold gesture. Generally Mary splays two fingers around her nipple to assist Christ with latching onto the breast. Recall Quirizio da Murano employed this gesture in his maternal image of Christ in The Savior (fig. 4.10). Remarkably in Marco d'Oggiono's work it is the Christ Child who positions his fingers around his Mother's nipple as he gazes directly at the viewer. The meaning is clear. Here he deliberately offers the viewer Mary's merciful breast. Additionally, in this painting Christ sits on a plinth, its edge

\footnotetext{
${ }^{484}$ The painting is an oil on wood banner painted for Santa Maria del Mercato at Fabriano. It bears the artist's signature but no date. It has been assigned to the late 1470s and the early1480s. The two-sided standard has the Flagellation painted on one side and this Madonna and Child on the other. It was likely used in processions. Antonio Paolucci, Luca Signorelli, ed. and trans. Lisa Pelletti (Florence: SCALA, 1990), 5. Tom Henry and Laurence Kanter, Luca Signorelli: The Complete Paintings (New York: Rizzoli International Publications, 2002), 19.
} 
made obvious by the sharp drop of drapery in the foreground. It is difficult to ignore the altar symbolism. Christ makes an offering of mercy to the faithful from the sacrificial altar.

A final example reveals an even more expressive Christ Child, actively presenting his mother's nourishment to the devotee. Bartolomeo Suardi, nicknamed Bramantino because he studied painting with Bramante, figured a nursing Christ Child in the mid1480s, now in the Museum of Fine Arts, Boston (fig. 4.28). In an iconographic innovation Christ's pace is situated behind Mary's breast. He is in mid-stride, his right arm swinging as his left foot pushes off in a forward thrust. His chubby right hip advances within the pictorial space. The unusual inclusion of sandaled feet emphasizes that he is walking. This is not a cuddly, helpless baby, nor do viewers witness an intimate moment. Bramantino's Christ is fully dressed, wrapped in toga-like garb. His left hand holds his mother's breast while his gaze zeroes in on the viewer as he literally brings his offering forward to the faithful - an offertory of the same life-giving nourishment of which he partakes. In the background a fortified brick town, rendered in perspective, helps push the figures in the foreground to the front of the picture plane. And the foreshortened left elbow advances almost into the space occupied by the observer. There is nothing tentative about the composition, and its energetic dynamism contrasts sharply with the serene scene of maternal feeding in Solario's Madonna with the Green Cushion. Christ's atypical pose, clothing, and footwear are so out of the ordinary that they surely caught the Renaissance viewer's full attention just as they do that of the modern observer. Full engagement of the viewer was achieved by the subjects' intense gaze and by pose and gesture, which deliberately beckoned spectators to 
receive the offering. Interacting with devotional images was a deeply personal experience filled with hope for heaven-sent blessings, and here, the direct invitation would have been hard to miss.

The inclusion of the faithful in the devotional image, in the devotional experience, affirms an active role for the artwork, one completed by the beholder's presence. ${ }^{485}$ Renaissance viewers knew how to interact with visual art. They knew Sacred Scripture well but had also been directed to visualize themselves in the scenes described in the readings. Spiritual exercises and meditations facilitated by such texts as Meditations on the Life of Christ and the Zardino de Oration, a prayer manual written in 1454 and printed in 1494, were common practices, as we have seen. When people heard the Gospels proclaimed and listened to the sermons that followed, they were encouraged to actively imagine themselves as a part of the scene under consideration. To explain the relationship between painting and beholder Michael Baxandall called the Renaissance devotional painting a "relic" of a cooperation between the artist and the viewer. "... The fifteenth-century experience of the [artwork] was an interaction between the painting, the configuration on the wall, and the visualizing activity of the public mind - a public mind with different furniture and dispositions from ours. ${ }^{, 486}$ Baxandall chose the term "visualizing activity;" devotional activity might also be used, which suggests that there was nothing passive about contemplating Renaissance-era religious artworks. The term

\footnotetext{
${ }^{485}$ John Shearman, Only Connect: Art and the Spectator in the Italian Renaissance (Princeton, NJ: Princeton University Press, 1992), 33. I have adapted the idea from John Shearman's work: “. . .the relationship between the work of art and the spectator is now fully transitive." The author defined "transitive" to clarify his point: "taking a direct object to complete the sense, passing over or affecting something else." Shearman credited Jacob Burckhardt for noticing how the artist engaged spectators, writing of a twelve-year-old Christ in a Bernardino Luini painting, Christ Among the Doctors of the Temple, "Christ does not teach them, he teaches us." Jacob Burckhardt, "Das Altarbild," in Beiträge zur Kunstgeschichte von Italien (Basel, 1898), 114; see Shearman, 36.

${ }^{486}$ Baxandall, 48.
} 
"relic" is an accurate one in that it underscores the concept that the painting is the tangible or corporeal thing that stimulates and records the spiritual, devotional activity. Baxandall and others have correctly asserted that each viewer brought his or her own experiences to the image. The effect of the devotional activity may have differed from person to person. However, among members of a similar community, it is fair to assert that their experiences resembled one another's. Devotional activity ranged from very public processions in the streets with crowds of participants to contemplative prayer conducted in the privacy of a one's own room. Images like those by Ambrogio da Fossano, Lo Spagna, Signorelli, Marco d'Oggiono, and Bramantino actively engaged beholders and conveyed the message that individual devotees were not alone. Help was available to all who prayed for it. Renaissance people were looking for a channel to the divine. Their contemplation, visualization, and prayers before images of the Madonna lactans were potent activities enhanced by the signifiers within the pictures. Gestures and directed gazes personalized such images, making their allure intoxicating. The message spoke of merciful nurturing available to all the faithful with the nursing Madonna functioning as an intercessory instrument to procure people's hearts' desires from God.

The concepts of the Virgin as merciful mother and as intercessor are not novel ones, and a number of scholars have made connections between the Madonna lactans image and the merciful Virgin. ${ }^{487}$ The correlation could have been made in the mind of viewers who were familiar with images of Madonna of Mercy and allegorical depictions

${ }^{487}$ For a thorough examination see Levin, "Studies in the Imagery," 546-710. See also Levin, "Advertising Charity." 215 - 309. The connection is also mentioned in Meiss, Black Death, 150 - 152, Lane, 7 - 8, Lilian H. Zirpolo, "Artemisia Gentileschi's Spada Madonna and the Trauma of Loss," in Essays on Women Artists “The Most Excellent," Book One, ed. Liana de Girolami Cheney (Lampeter, Ceredigion, Wales: The Edwin Mellen Press, Ltd., 2003), 56, and Warner, 198 - 200. 
of Charity found in churches and prayer books across medieval and Renaissance Europe. They recognized allegories of Charity and Mercy in, among other things, the simple gesture of the figure touching her breast. The same gesture is present in the paintings last reviewed.

Mary is touching her breast in three of the five paintings just examined and in the Nelli drawing, as well. Mary touches her breast in Solario's Madonna with the Green Cushion too, but only to aid her nursing activity. As Christ does in the Auckland Madonna del Latte (fig. 4.28) Mary employs the scissor or V-hold to press the full breast back from the nipple so Christ can latch on more easily. There is a practical purpose in the gesture. But in the nursing Madonna images by Ambrogio (fig.4.23), Signorelli (4.26), Bramantino (fig. 4.28), and Nelli (fig.4. 12), Mary is touching her breast with no apparent practical purpose, such as to aid in the process of feeding. Images depicting the Madonna of Mercy also often employ Mary's breast-touching gesture as a signifier. As William Levin has demonstrated, the iconographic element of touching one's bosom to indicate love between human beings has a long heritage. ${ }^{488}$ For example, a South German Gospel Book dating from the beginning of the eleventh century offers an illumination depicting personifications of Poverty, Chastity, Obedience, and a fourth figure labeled "Unice pietatis affectus," - Solely the affection of Piety. This fourth figure places both of her hands upon her bosom. ${ }^{489}$ Levin explained that according to its biblical and classical meanings Piety is defined as "familial affection and respect, a love and faithfulness that actively passes between one human being and another, and therefore

\footnotetext{
${ }^{488}$ Levin, "Studies in the Imagery of Mercy," 575-76.

${ }^{489}$ Levin, "Studies in the Imagery of Mercy," 575-76.
} 
comes under the broader concept of Mercy." ${ }^{, 40}$ The definition describes love of neighbor, Amor proximi. In the Cathedral of Basel there are several carved reliefs depicting love of neighbor using the breast-touching gesture. For instance, one relief near the Door of St. Gall portrays a man dressed in rags being guided by a wimpled woman who takes his hand in her own and places them on her breast. The carved inscription reads, "Pauper, Misericordia, Luchart," thus labeling the indigent man, the assisting woman - who is dubbed Mercy - and the sculptor, respectively. ${ }^{491}$ In Italy the theme is represented late in the fifteenth century as a carved personification of Charity for the Tomb of Doge Andrea Vendramin, now in SS. Giovanni e Paolo in Venice. The Charity figure touches her right breast with one hand and holds a bowl of flames with the other. ${ }^{492}$ In these examples presented the personifications of Piety, Mercy and Charity touch their breasts, each signifying giving of oneself, one human being to another. In the paintings listed above, not only does Mary touch her breast, signifying mercy, but the Christ Child makes certain the message is received by viewers. He reinforces the message by also presenting his mother's breast. The hands of Signorelli's, Ambrogio's, and Nelli's Christ figures frame the offering while his intense look is directed toward the devotee. Marco d'Oggiono's Christ employs the practical scissor hold making it easy for devotees to latch onto the breast of mercy. Bramantino's Christ goes to greater lengths, virtually delivering the offering at the devotee's feet. In her letters St. Catherine of Siena encouraged people to take nourishment from the sweet breast as well. She wrote about

\footnotetext{
${ }^{490}$ Levin, "Studies in the Imagery of Mercy," 576.

${ }^{491}$ Levin, "Studies in the Imagery of Mercy," 577.

${ }^{492}$ Levin, "Studies in the Imagery of Mercy," 577. The flame (as well as a heart) symbolizes another piece of the larger Caritas theme - love of God, Amor Dei. See Levin, as in n. 123 above. See also R. Freyhan, "The Evolution of the Caritas Figure in the Thirteenth and Fourteenth Centuries," Journal of the Warburg and Courtauld Institutes, 11(1948), 68 - 86.
} 
the breast and its metaphorical role in charity. She insisted that unless people first attach themselves to the divine breast, being charitable to one's neighbor will be impossible. ${ }^{493}$ In an earlier letter she had placed Christ in the role of breast-feeding nurturer; ${ }^{494}$ however, in this letter she specified the mother of charity as the donor of the milk.

Dearest mothers and sisters in Christ Jesus Our Lord, I, Catherine ... write to you in his precious blood, with the desire of seeing you rooted in true and perfect charity, so that you can be true caretakers of your souls. He has decreed that we cannot take care of another if we do not first nourish our own soul with true and genuine virtues; and one cannot nourish oneself with virtue if one is not first attached to the breast of divine charity, a breast from which one draws the milk of divine sweetness. . . And we would not be able to nourish ourselves with this milk that we draw from the mother of charity without suffering.

Thus, Saint Catherine explicitly recommended nourishing one's soul at the mother of charity's breast, just as the gestures and pointed gazes did in the images. In the same letter she wrote of the purpose of suffering, declaring that love calls for co-suffering, literally, "compassion."

[B]ut love does this, making itself weak with those who are weak ... weeping with those who are in the season of grief ... The soul takes the flesh of Christ crucified, carrying the cross in pain with him, ... the pain that is love, to follow the footsteps of Christ crucified, and thus taste the milk of divine sweetness. ${ }^{495}$

Hence, Saint Catherine revealed the rewards of the suffering, ultimately to taste the milk of divine sweetness. The Madonna lactans image coupled with an image of the suffering Christ functioned as a locus for people to ask for rewards and mercy $-\mathrm{a}$ focus for their pleas for intercession - in order to "taste the milk of divine sweetness." And a number of intercessory themed paintings associated the suffering Christ with the Madonna lactans

\footnotetext{
${ }^{493}$ Santa Caterina, Le Lettere, vol. 6, letter 2, p. 5.

${ }^{494}$ See Santa Caterina, Le Lettere vol. 2 letter 86, p. 81.

${ }^{495}$ Santa Caterina, Le Lettere, vol. 6, letter 2, p. 5. My gratitude to Msgr. William F. Cleves for his help with translations.
} 
image. They depict Christ pleading with his Father as he shows the side wound he incurred during his Passion while Mary beseeches her Son to intervene in recompense for having nursed him. Again people made the connection because of the breast imagery. When coupled with period writings, sermons, and miracle stories, the message that Mary's powerful intercession for help and mercy was attainable was apparent to devotees. A few examples of intercessory images and texts of this sort will deepen our understanding of the connection made by Renaissance people.

\section{The Double Intercession}

In order for Mary to dispense mercy, she had to follow the correct intercessory process. The Virgin is depicted with her grown Son interceding on behalf of the faithful in The Intercession of Christ and the Virgin, a painting from ca. 1402, which once adorned the Florence Cathedral as a prominent altarpiece just inside the main portal (fig. 4.29). It is now in the Metropolitan Museum of Art in New York. In it Christ, on God's right, shows his side wound to his Father with one hand and with the other, in an expressive, elegant gesture, conveys a petition for his Mother's request. Thus the order is established. Christ addresses his Father through Italian text inscribed on the painting: "My Father, let those be saved for whom you wished me to suffer the Passion." Mary, kneeling on God the Father's left, grasps her bared breast with one hand and indicates eight diminutive kneeling figures at her hem with the other. In the tradition of the latefourteenth- to early fifteenth-century images of the Madonna lactans, one breast is visible as a virtually unattached appendage; the other side of her chest is flat. The Virgin addresses her Son, "Dearest Son, because of the milk that I gave you, have mercy on 
them." ${ }^{496}$ Both Christ and his Mother make a plea for mercy, and both use the rationale of a debt owed to acquire it. Christ appeals directly to the Father, indicating the wound in his side as the justification for granting his petition. Mary addresses her Son, calling in the favor of having suckled him. Dispatched from the Father, the dove of the Holy Spirit descends toward Christ, golden rays emanating down, indicating the favors have been granted. The prominent placement of this painting sent every churchgoer a clear message as they entered the Florence Cathedral. ${ }^{497}$ Christ and his Mother were not only inclined to intervene but were successful mediators, by virtue of their suffering and feeding, respectively, to attain mercy for the faithful. Together they were indomitable.

The pair of mediators appears again in the mid-fifteenth-century Turin-Milan Book of Hours (fig. 4.30). They are found in a miniature of the same Double Intercession theme in which an enthroned God the Father sits, not in heaven this time, but on the same plane as his supplicants. He appears as king and judge, holding a scepter and an orb. Mary, kneeling on God's left, bares one breast, her palm open, and Christ on his right, kneeling on the pillar of his Passion, gestures to his Father with one hand and his side-wound with the other. No supplicating crowd of sinners is gathered, as in the previous painting. In this case, the lone sinner would have been the devotee holding the book. People would have read their prayers while meditating on the miniature, asking for intervention. The small devotional image lent a personal, private quality to the act of

\footnotetext{
${ }^{496}$ The translation appears on The Metropolitan Museum of Art website. The Metropolitan Museum of Art http://www.metmuseum.org/Collections/search-thecollections/70010757?rpp $=20 \& p g=1 \& \mathrm{ft}=$ Intercession + of + Christ + and + Mary \&pos $=3$. Millard Meiss provided the original text in his examination of the painting: Millard Meiss, "An Early Altarpiece from the Cathedral of Florence" The Metropolitan Museum of Art Bulletin 12, no. 10 (1954), 306.

${ }^{497}$ For a detailed discussion on the placement of the painting in the Cathedral see Meiss, "An Early Altarpiece," $310-312$.
} 
prayer, likely prompting the devotee to visualize herself or himself in the scene, just as other devotional texts had taught them to do.

Another widely-read text, the Miracles of the Blessed Virgin, was composed around 1435 by Johannes Herolt, who signed it Discipulus. He included the tale of a hard-hearted sinner who at the end of his life was surrounded by devils clamoring to claim his soul. Despite his sinful ways the man was devoted to the Blessed Virgin and had recited one-hundred "Hail Marys" each day. Knowing his manifold sins, God the Father condemned him. In the meantime the Virgin offered an accounting of these prayers to her Son, begging for mercy on her devotee's behalf. The devils fought back, bringing books listing all of the man's sins. The two ledgers were put on scales, and the sins out-weighed the prayers. Now the Virgin implored her Son in earnest:

Remember, Beloved, that Thou didst receive of my substance, visible, tangible and sensible substance; give to me one drop of Thy blood shed for sinners in Thy Passion. And he replied: 'It is impossible to deny thee anything. Yet know that one drop of my blood weighs heavier than all the sins of the whole world. Receive therefore thy request. ${ }^{498}$

In the end the defeated devils departed complaining, "The Lady is too merciful to Christians; we fail as often as she comes to contend with us." ${ }^{499}$ Note that, as in the images, the Virgin and Christ worked together, the Virgin offering the act of nursing without naming it specifically, and Christ offering his blood, shed for the sake of sinners. God the Father as judge, inclined toward conviction, had to be convinced otherwise. Again the hierarchical chain passed from sinner to Virgin, Virgin to Christ, then Christ to his Father. The Virgin's mercy was unconditional, and a reminder of her breast-feeding secured leniency.

\footnotetext{
${ }^{498}$ Herolt, 77.

${ }^{499}$ Herolt, 77.
} 
These texts worked in tandem with the images, and the faithful understood the straightforward correlation between images of intercession and the nursing Madonna images. Both were symbols of Mary's unqualified compassion and her guarantee of mercy for her devotees through the immutable bond forged when she nursed her Son. ${ }^{500}$

Another version of the theme is in a fresco by Benozzo Gozzoli located on the southern nave wall in Sant' Agostino in San Gimignano (fig. 4.31). The upper portion of the painting forms the triangle of Father, Son, and Virgin similar to the Metropolitan Museum painting. In the lower half Saint Sebastian is standing on a pedestal surrounded by people who have taken their petitions to him, initiating the intercessory chain of command (fig. 4.32). The people brought their prayers to Sebastian, Sebastian petitioned the Virgin, and the Virgin lobbied Christ, who then made a plea to the Father. Saint Sebastian was the patron saint Christians appealed to for protection against the plague, and in fact, the painting was executed during an outbreak of the disease in $1464 .^{501}$ As in the Metropolitan painting and the miniature, Christ looks up at his Father as he indicates his wound with one hand. With the other he points to St. Sebastian. But in this intercessory image, Mary's breasts (and by association, her breastfeeding) play an even more prominent role. She bares both breasts, executed with the heightened realism of

\footnotetext{
${ }^{500}$ The pairing of the two themes, Suffering Christ with Madonna and Child had predecessors in late medieval diptych altarpieces. Quite often small in size, they were used as portable altarpieces or personal devotionals. The Man of Sorrows image was juxtaposed with images of the Virgin and Child, hinged together to imply intercession, a theme that became explicit with the Renaissance Double Intercession motif. See Meiss, "Early Altarpieces," 309, MacGregor 126 - 27, Camille, Gothic Art, 118 - 19, and Levin, "Imagery of Mercy," chap. 6.

${ }^{501}$ The painting, called a Pestbilder, was a painted prayer against the ravages of the plague. Gozzoli would have interrupted his work on the main chapel's decoration, Episodes from the Life of St. Augustine, in order to finish this one in 1464, as the inscription on Sebastian's pedestal reveals, indicating a sense of urgency for its completion. A restoration and study of the work conducted in 1990 concluded the painting was completed in just sixteen days. Emil Kren and Daniel Marx, Gozzoli, Benozzo, Saint Sebastian, Intercessor, http://www.wga.hu/frames-e.html?/html/g/gozzoli/5various/4interce.html. Serena Nocentini, Museo Benozzo Gozzoli, http://www.museobenozzogozzoli.it/works/SaintSebastian.html.
} 
mid-fifteenth century Italian art, and likewise gestures toward St. Sebastian and the crowd below as she stares pointedly at her Son, as only a mother can do. This time the players pantomime the message eloquently without need or benefit of an inscription, and the period churchgoer would have understood it well. The action in this painting takes place before the verdict from the Father has been decided. He has aged since the earlier Metropolitan version, and his angry scowl and the arrow held aloft tells the spectator all is not yet forgiven of the sinners below. Suspense is amplified by the army of angels poised to hurl their own arrows at the world below. The image of the Virgin baring both breasts may be unsettling to modern viewers, but the Renaissance public would have been well acquainted with the symbolism and likely been able to guess the outcome. Christ and Mary's double intercession would secure clemency. A widely disseminated twelfth-century manuscript written by Ernaldus of Chartres (and soon thereafter erroneously ascribed to well-known Marian devotee, Bernard of Clairvaux) gave away the ending.

Man has now secure access to God where he has the Son as mediator for his cause before the Father and the mother before the Son. Christ, His Flank exposed, shows the Father His side wound; Mary shows Christ her breasts; and nor is it possible in any way, when [Christ and Mary] come together to plead very eloquently in every tongue, for these monuments of mercy and signs of charity to be repulsed. The mother and Son divide the office of piety in the presence of the Father ... Mary sacrifices herself to Christ in spirit and entreats [for] salvation of the world, the Son requests it, the Father pardons. ${ }^{502}$

The text made the intercession process crystal clear, and the confident tone assured success. There are other popular texts which supported the images. The Speculum humanae salvationis (Mirror of Human Salvation) was written in the beginning of the fourteenth century and quickly became one of the most widely read of all religious

\footnotetext{
${ }^{502}$ Zirpolo, 57. Meiss, “An Early Altarpiece,” 306.
} 
texts. $^{503}$ The Speculum likewise was illuminated with illustrations of intercessory images of Christ showing his wound to his Father and the Virgin indicating her breast to her Son.

The small devotional paintings in which Mary and Christ make invitations with their gestures and directed gazes were engaging and magnetic to Renaissance worshipers. In these later paintings the Christ Child has awakened and plays an active role. No longer simply a hungry baby, he is as dynamic as Mary and sometimes more so, making the same promise of mercy and intercession we find in the Double Intercession images, populated with an adult Christ. The presence of God the Father as judge in those intercession images signifies a specific type of intercession: the Salvation of souls. Yet it is difficult to know exactly what petitions individual supplicants brought before the images. Recall that the Benozzo Gozzoli image was painted during an outbreak of the plague and Saint Sebastian was the patron saint of protection against the disease. Whether the aspiration was forgiveness of sins and salvation, or intervention about disease or fertility, the goal of merciful intercession was the same for both types of images. Divine mercy and love was available to the faithful who prayed before the image in the Florence Cathedral, just as it was available in the small devotional image, from a mother and Child. And what an influential Child he was.

${ }^{503}$ Meiss, “An Early Altarpiece,” 306. 


\section{Conclusion}

A desire for a deep communion with the divine characterizes the medieval and Renaissance response to the Madonna lactans image. It is the common response shared by most of the viewers in this study. Deep communion was the goal of nuns who prayed before the image in the privacy of their cells, by Renaissance supplicants begging for intercession, and by late medieval Mass goers when they gazed at the image behind the altar.

The very interactive way in which people engaged with images during the period of our study has been a critical consideration. Peoples' understanding of what happened while gazing was explained in period texts about the way vision worked. The viewer's very soul was an integral part of the process. Augustine and others emphasized that a visual "ray" connected the seer with what was seen and a spiritual transformation occurred. ${ }^{504}$ Margaret Miles elucidated, "By the vehicle of the visual ray, the object is not only 'touched' by the viewer, but the object is also 'printed' on the soul of the viewer." 505 Due to infrequent reception of the Eucharist in the medieval period, people engaged in a practice called spiritual communion, an activity in which gazing at the Host

\footnotetext{
${ }^{504}$ Xavier John Seubert, OFM, STD, "Liturgical Instruments and the Placing of Presence," in Perspectives on Medieval Art: Learning through Looking, ed. Ena Giurescu Heller and Patricia C. Pongracz (London: Museum of Biblical Art, 2010), 141 - 43.

${ }_{505}$ Margaret Miles, Rereading Historical Theology: Before, During, and After Augustine (Eugene, OR: Cascade Books, 2008), 208.
} 
was tantamount to receiving it. The Madonna lactans motif was a favorite altarpiece adornment. When people fixed their eyes on it overlaid by the consecration rite and the Elevation of the Host, communion with the divine was felt intensely. The sacramental efficacy of the image profoundly graced medieval believers. Recall Michael Camille put the belief in the supernatural element of medieval religious images succinctly: "The notion of the 'real presence' in eucharistic practice must have deeply influenced people's perception of images, for here a visual thing was itself capable of becoming and not just signifying its prototype. ${ }^{, 506}$ Hence people's understanding of a religious image went well beyond their taking pleasure in a picture of a nursing mother and her baby. Furthermore, liturgical settings were laden with sensory signifiers. They included the pungent fragrance of incense, the tinkling of bells, mystical light streaming through stained glass, and the sound of the priest's transubstantiating prayers.

A less dramatic setting was replicated in peoples' homes for private devotion. Bedchamber altars were fitted with candelabra and receptacles for holy water. The large numbers of these small devotional Madonna lactans paintings confirm their popularity and usage. The Madonna lactans image was available to the nobility and peasant. Working class people could revere the nursing Madonna in tabernacle roadside shrines or in mass-produced, affordable bronze plaquettes, a medium in which the relief was rubbed in the truly private venue of a devotee's pocket. Devotion to an icon in which eating was so prominent a feature asked for the engagement of all the senses. Seeing merely initiated the experience.

${ }^{506}$ Camille, The Gothic Idol, 217. 
The intensity of experiencing communion with the divine had to do with what believers embraced in their interpretive communities. We see this spiritual union in its most extreme model among visionaries who imagine themselves nursing Christ or being nursed by him. In more subtle manifestations, the nursing Virgin was the saint to which people appealed for favors. Pilgrims to milk-relic and Madonna lactans shrines asked for abundant milk. Wet nurses and new mothers struggling with inadequate milk supplies prayed for food from heaven. But the help requested of Mary was not limited to something so literal. In fact, the literal reading was the exception rather than the rule. Remember Hans Belting explained that the medieval viewer experienced "a recognition of the cult image not as an aesthetic illusion or as a work of an artist but as a manifestation of a higher reality - indeed, as an instrument of supernatural power., ${ }^{507}$ The nursing Madonna image was such an instrument. People understood that nothing would be refused the mother and Son portrayed in the image. As the two figures directed their intense stare at the audience and gestured to Mary's breast, devotees believed in a merciful outcome. The message was apparent in the small devotional lactans paintings, but the meaning was made clearest in an image of the adult pair, which delivered the intercessory message, presenting the faithful with the hierarchical ladder of supplication. As they entered the enormous Florence Cathedral in the early years of the fifteenth century, Italians encountered the Double Intercession of Christ and the Virgin, a painting attributed to Lorenzo Monaco. If the inscription on the painting did not teach them, period texts and sermons supported the message. The Virgin's inscription reads,

\footnotetext{
${ }^{507}$ Belting, 47.
} 
"Dearest Son, because of the milk that I gave you, have mercy on them."508 The Virgin holds her breast in her hand - the instrument of supernatural power.

Whether the Madonna lactans was in the form of a crude fresco above a Franciscan altar for multitudes of pilgrims celebrating Christmas, or a modest drawing rendered by a nun for her private edification, late medieval and Renaissance audiences understood they were included in the invitation to accept merciful intercession. Even as naturalism became increasingly prevalent, people believed that the Virgin's breast was an instrument of supernatural power and the means to communion with the divine.

\footnotetext{
${ }^{508}$ The Metropolitan Museum of Art website. The Metropolitan Museum of Art http://www.metmuseum.org/Collections/search-thecollections $/ 70010757$ ? $\mathrm{pp}=20 \& \mathrm{pg}=1 \& \mathrm{ft}=$ Intercession + of + Christ + and + Mary\&pos $=3$.
} 


\section{ILLUSTRATIONS}




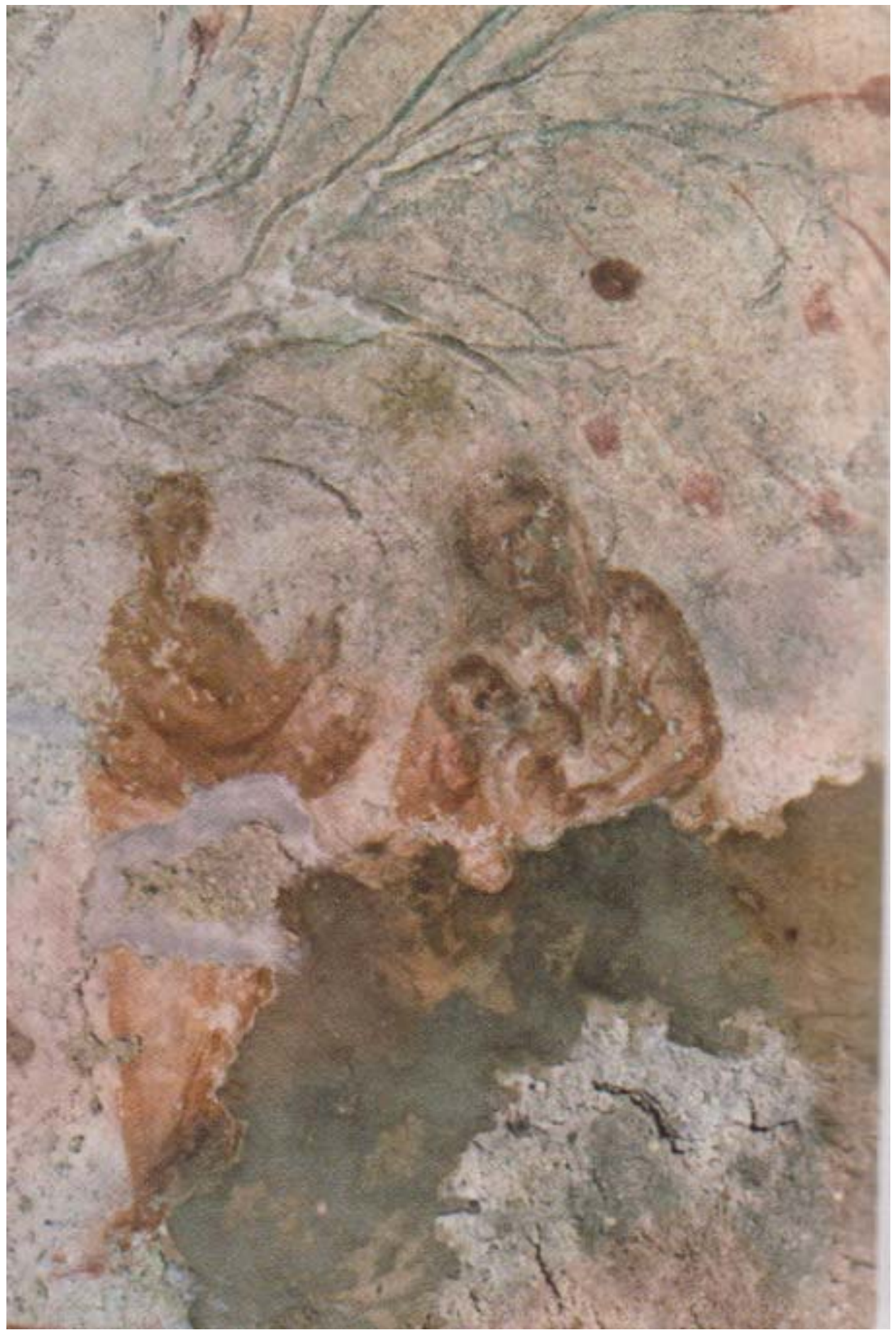

Fig. 1. Virgin Suckling the Christ Child, ca. between the second and the fourth century, Catacomb of Priscilla, Rome. 


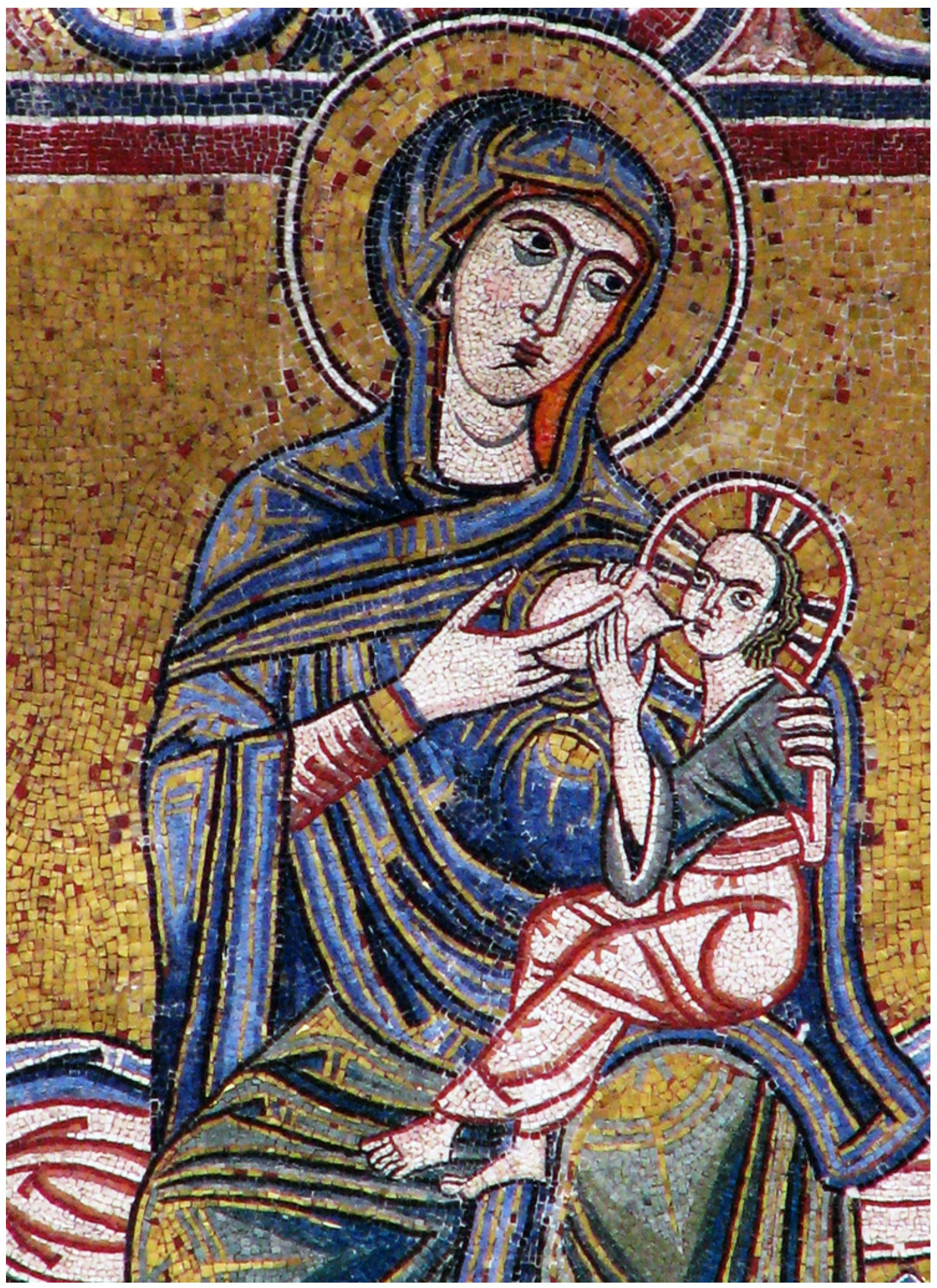

Fig. 2. Madonna and Child, twelfth century, mosaic, S. Maria Trastevere, Rome. 


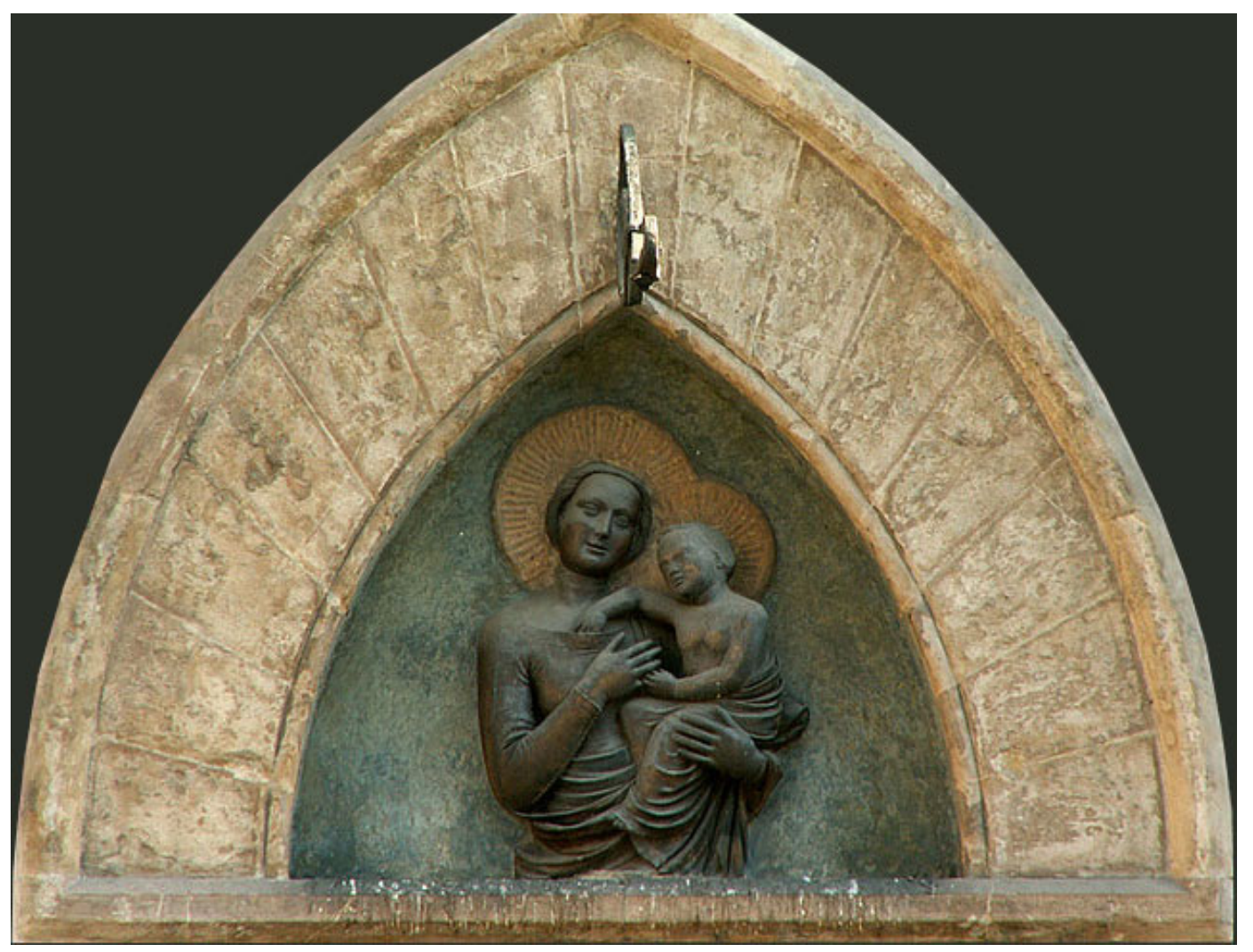

Fig. 1.1 Alberto Arnoldi, Madonna and Child, 1361, Museo del Bigallo, Florence. 


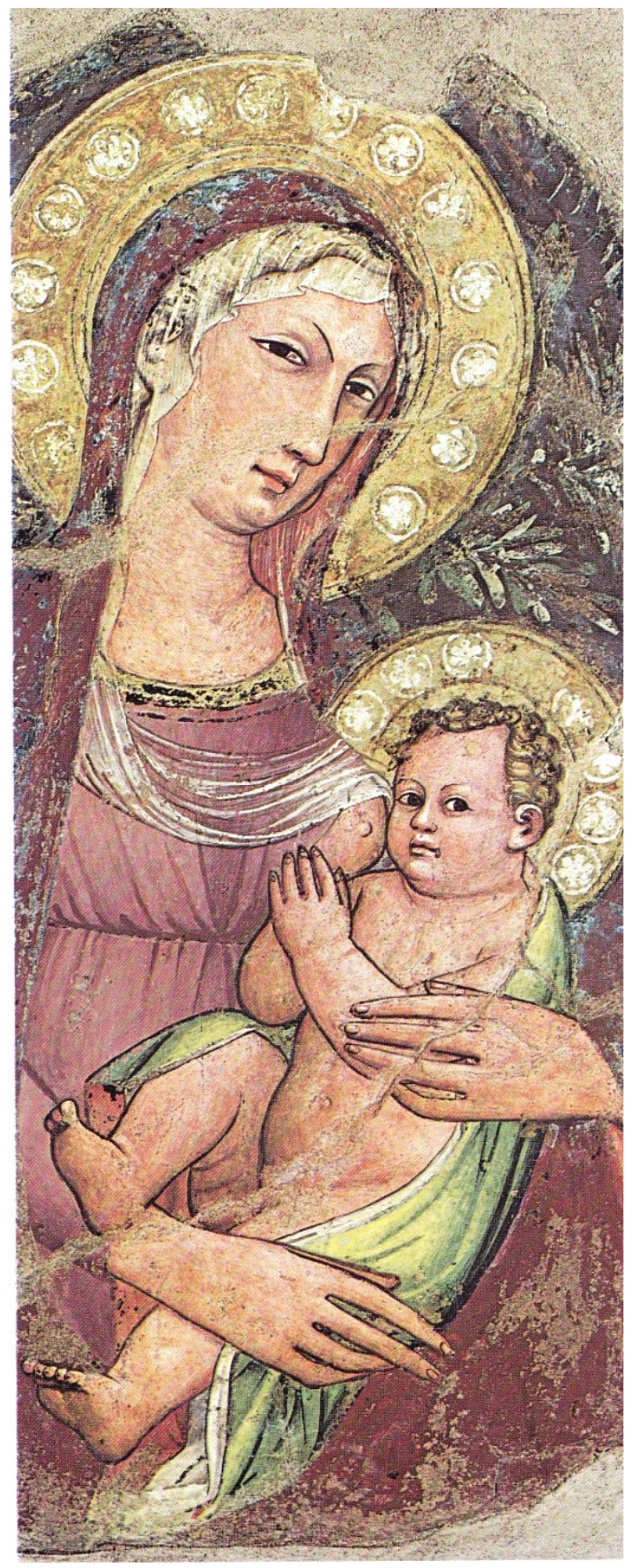

Fig. 1.2. Cenni di Francesco di Ser Cenni, Madonna with Child, late fourteenth or early fifteenth century, removed fresco, Spedale e Museo degli Innocenti, Florence. 


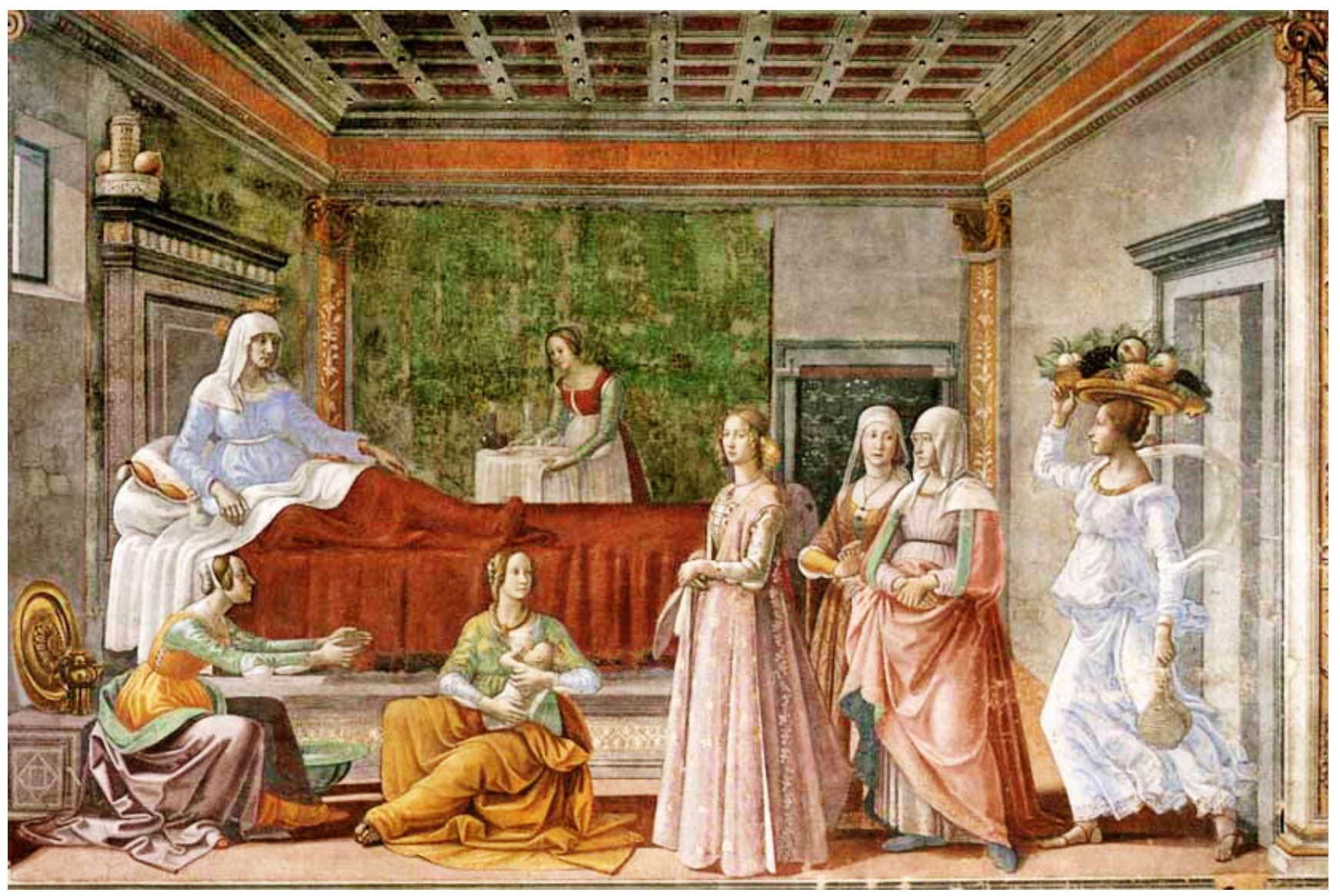

Fig. 1.3. Domenico Ghirlandaio, Birth of John the Baptist, 1485 - 90s, fresco, S. Maria Novella, Florence. 


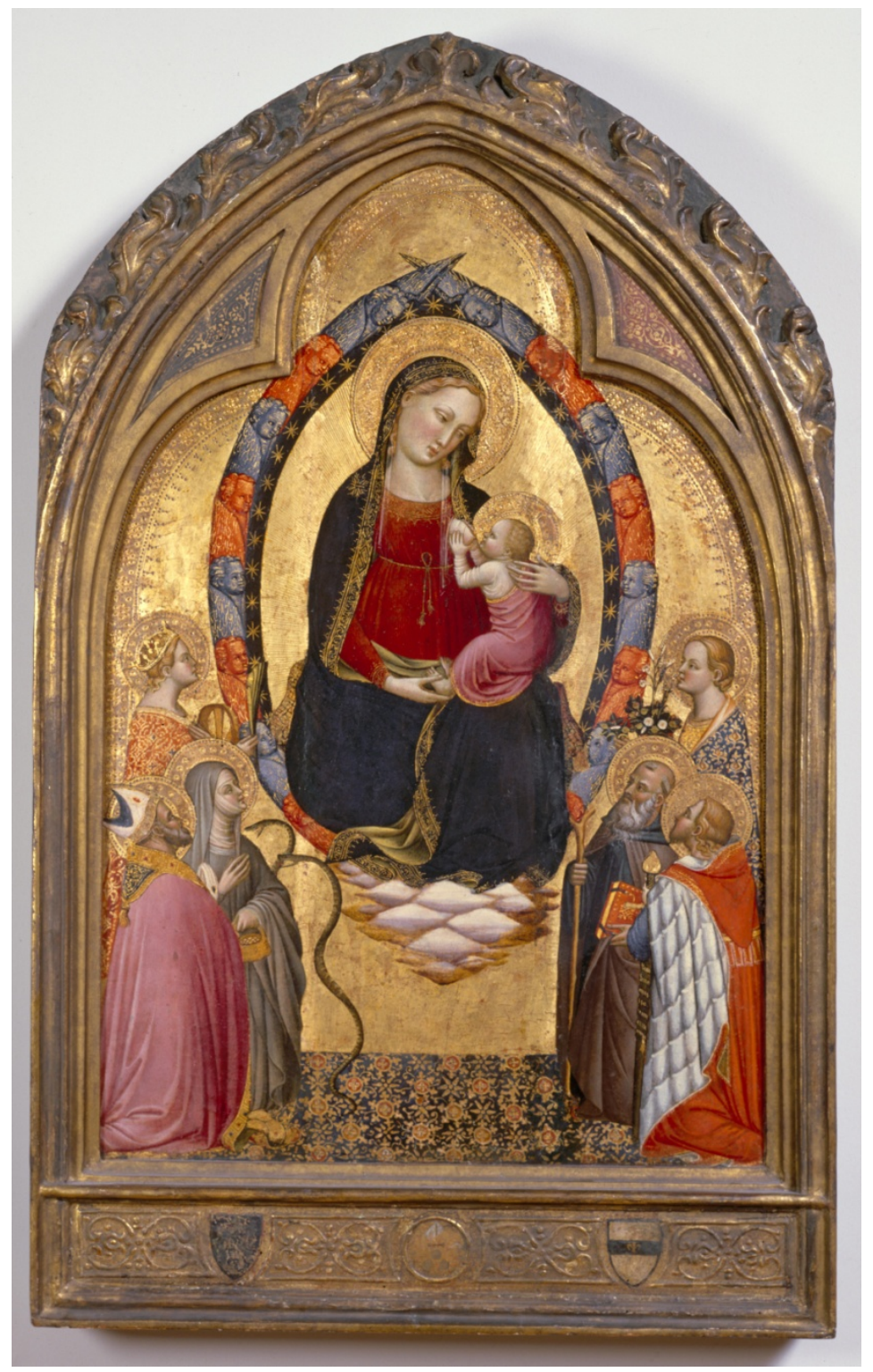

Fig. 1.4. Tomasso del Mazza, Madonna and Child with Six Saints, ca. 1390, tempera on panel, High Museum of Art, Atlanta. 


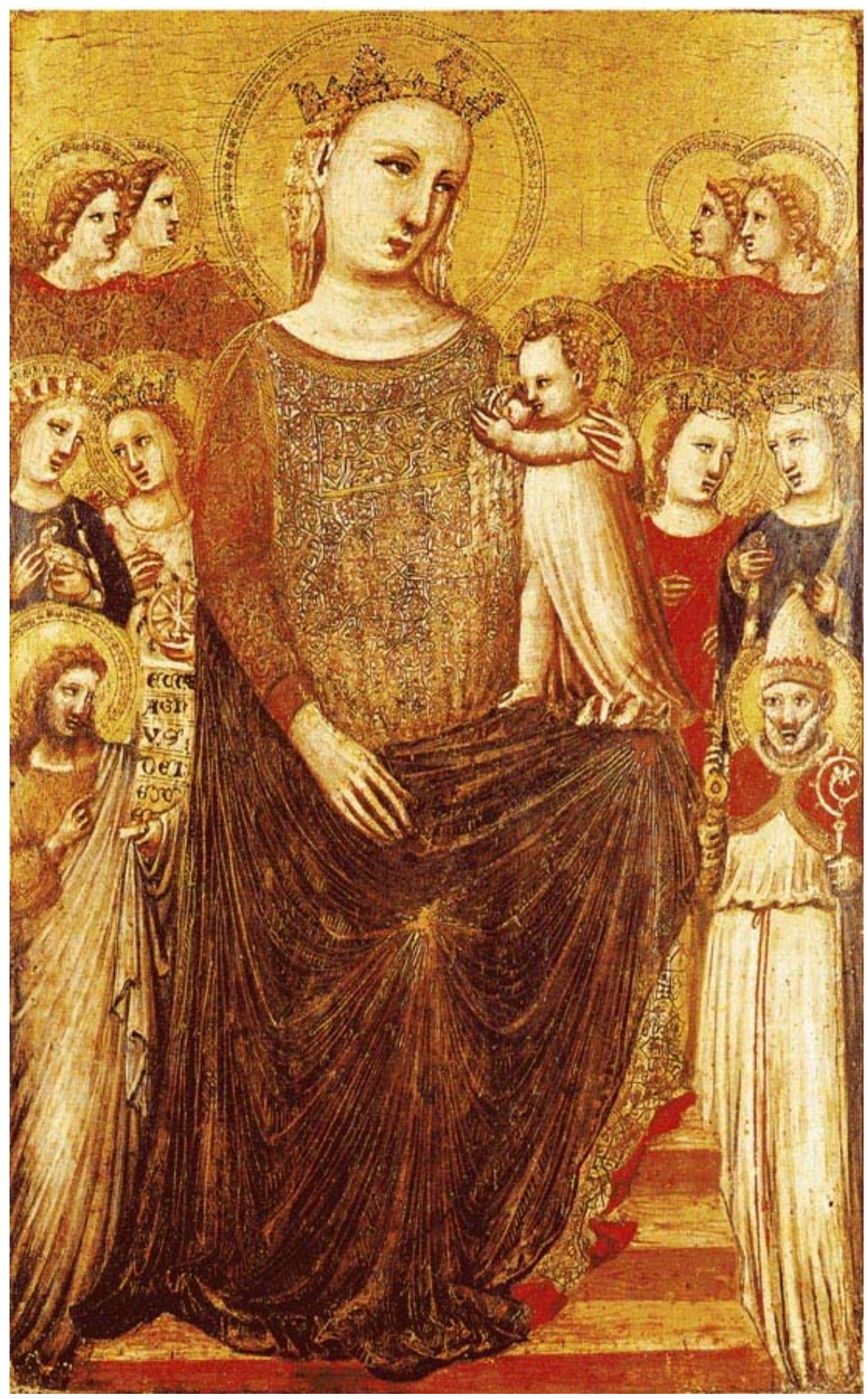

Fig. 1.5. Pietro da Rimini, Madonna and Child, early fourteenth century, Longhi Foundation, Florence. 


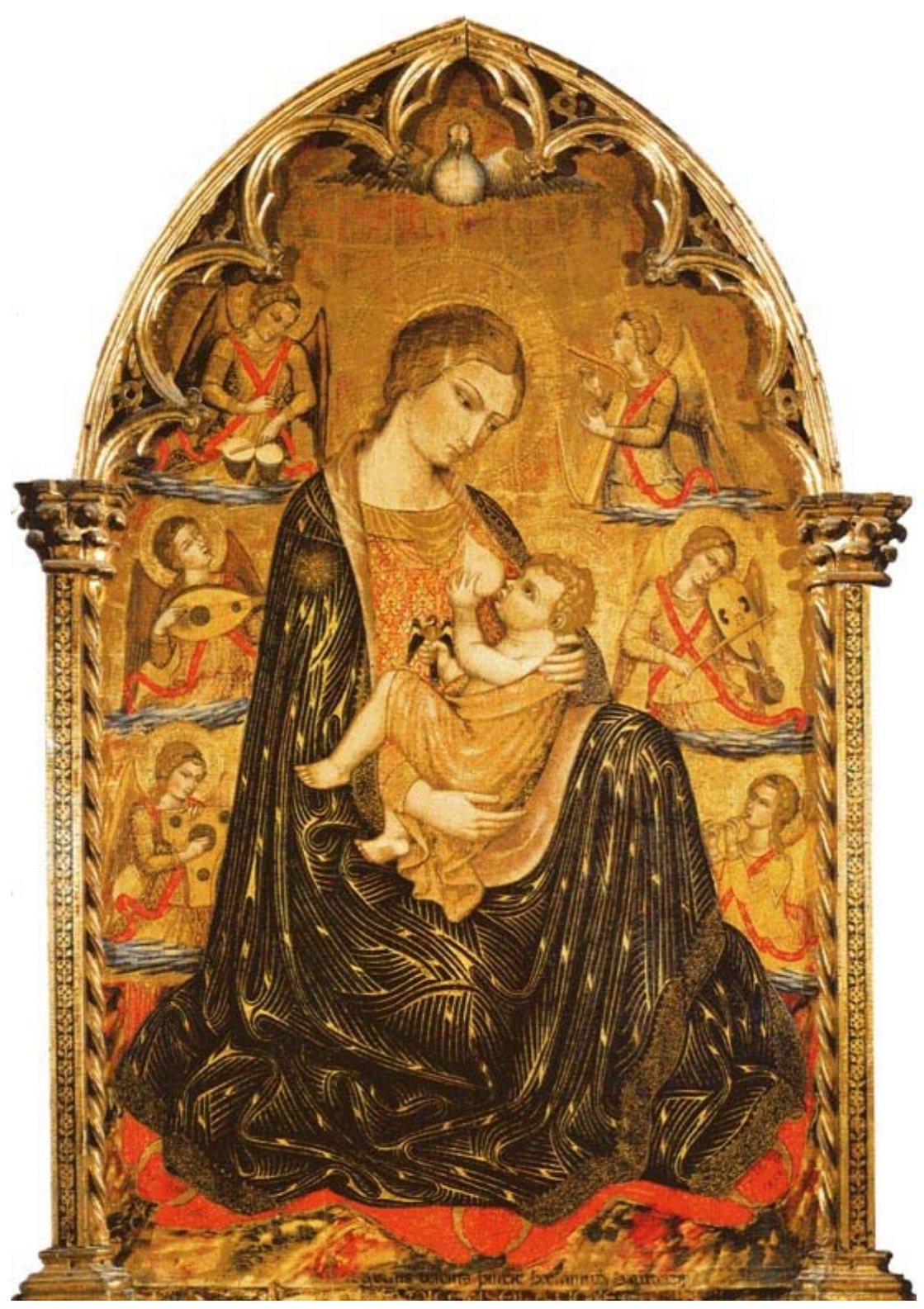

Fig. 1.6. Gregorio di Cecco, Virgin of Humility with Angels and Saints, detail of polyptych, painting on panel, early fifteenth century, Museo dell'Opera, Siena. 


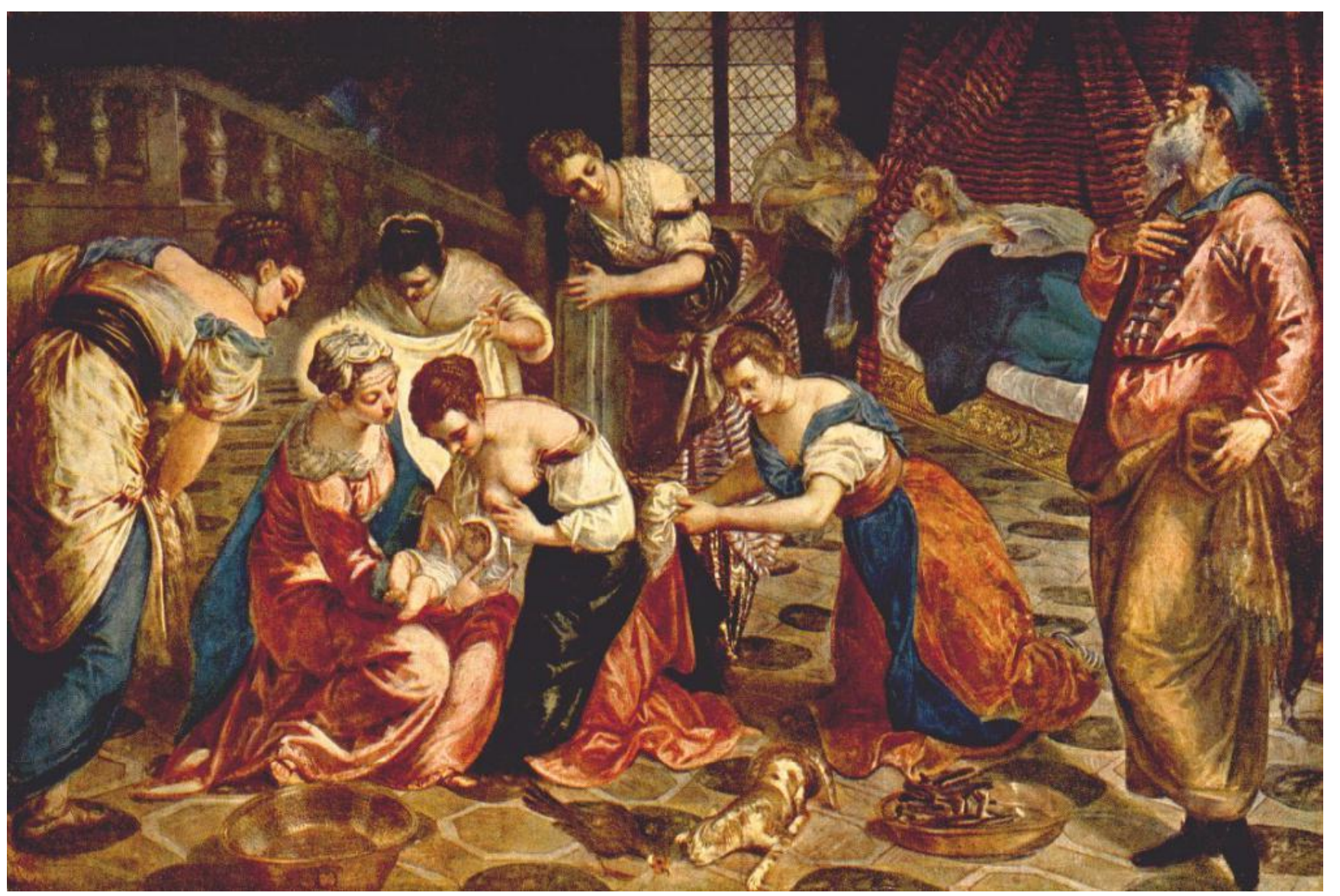

Fig. 1.7. Jacopo Tintoretto, Birth of John the Baptist, 1550s, Hermitage Museum, St. Petersburg. 


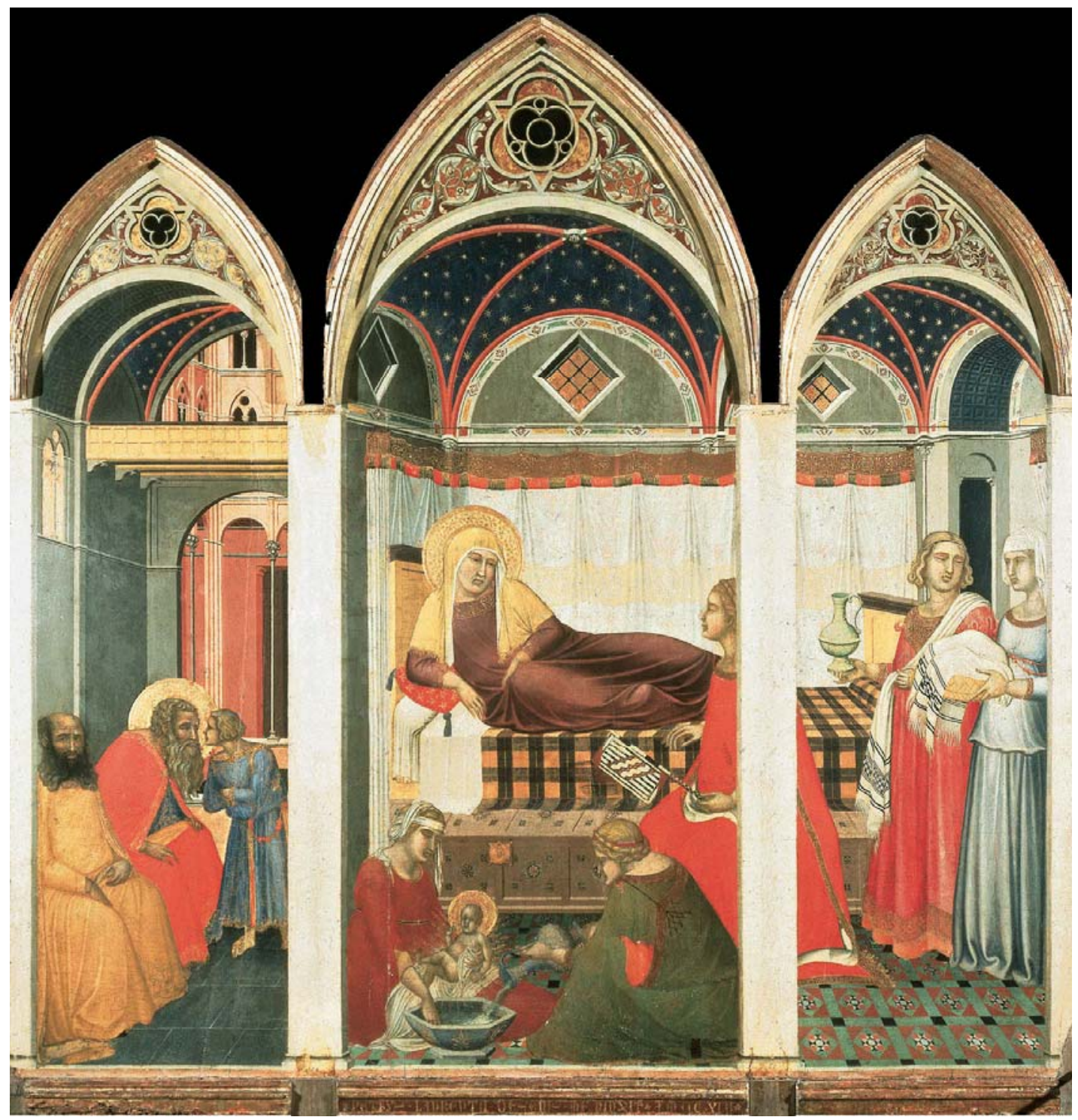

Fig. 1.8. Pietro Lorenzetti. The Birth of the Virgin, 1342, Museo dell'Opera del Duomo, Siena. 


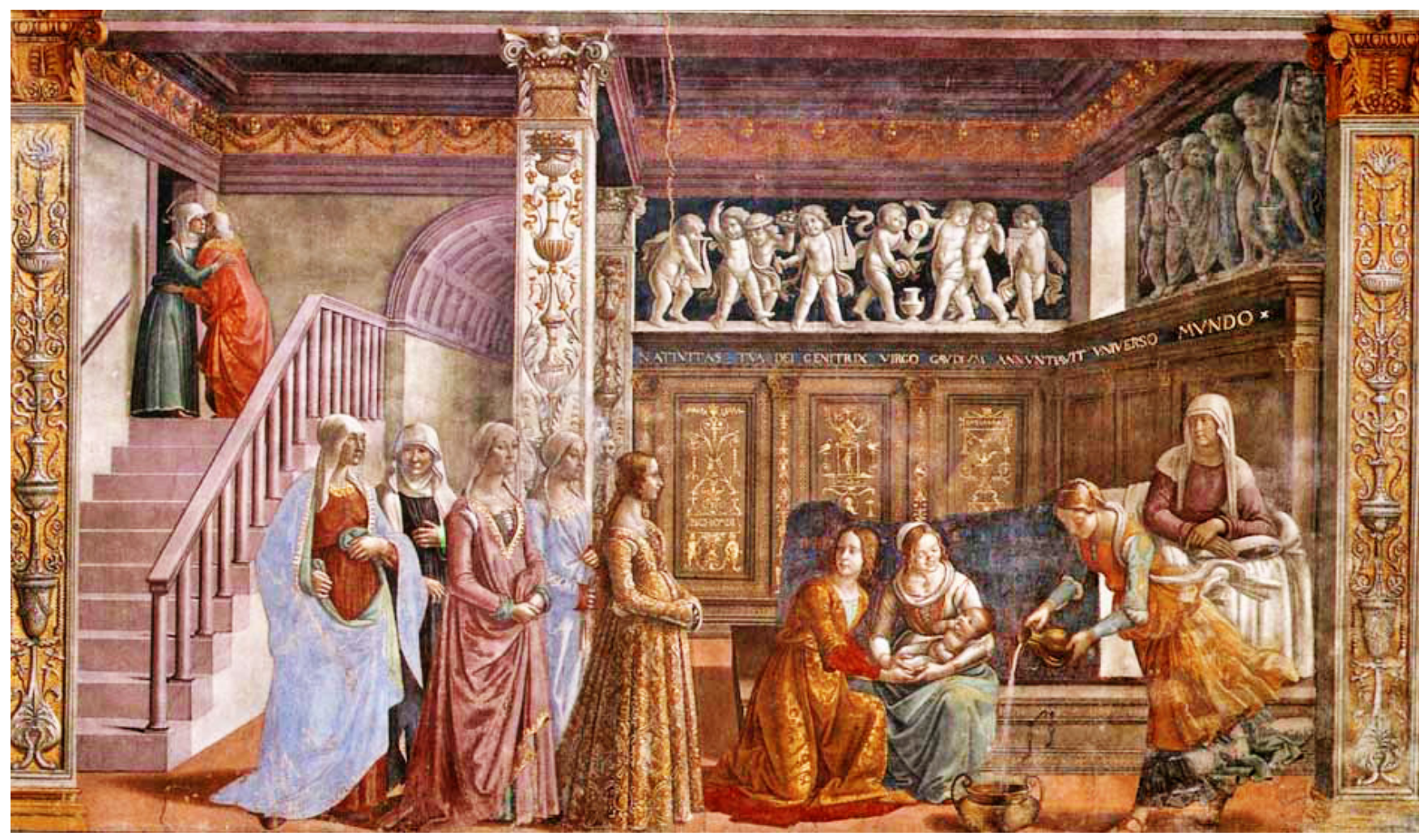

Fig. 1.9. Domenico Ghirlandaio, Birth of the Virgin, 1485 - 90s, fresco, S. Maria Novella, Florence. 


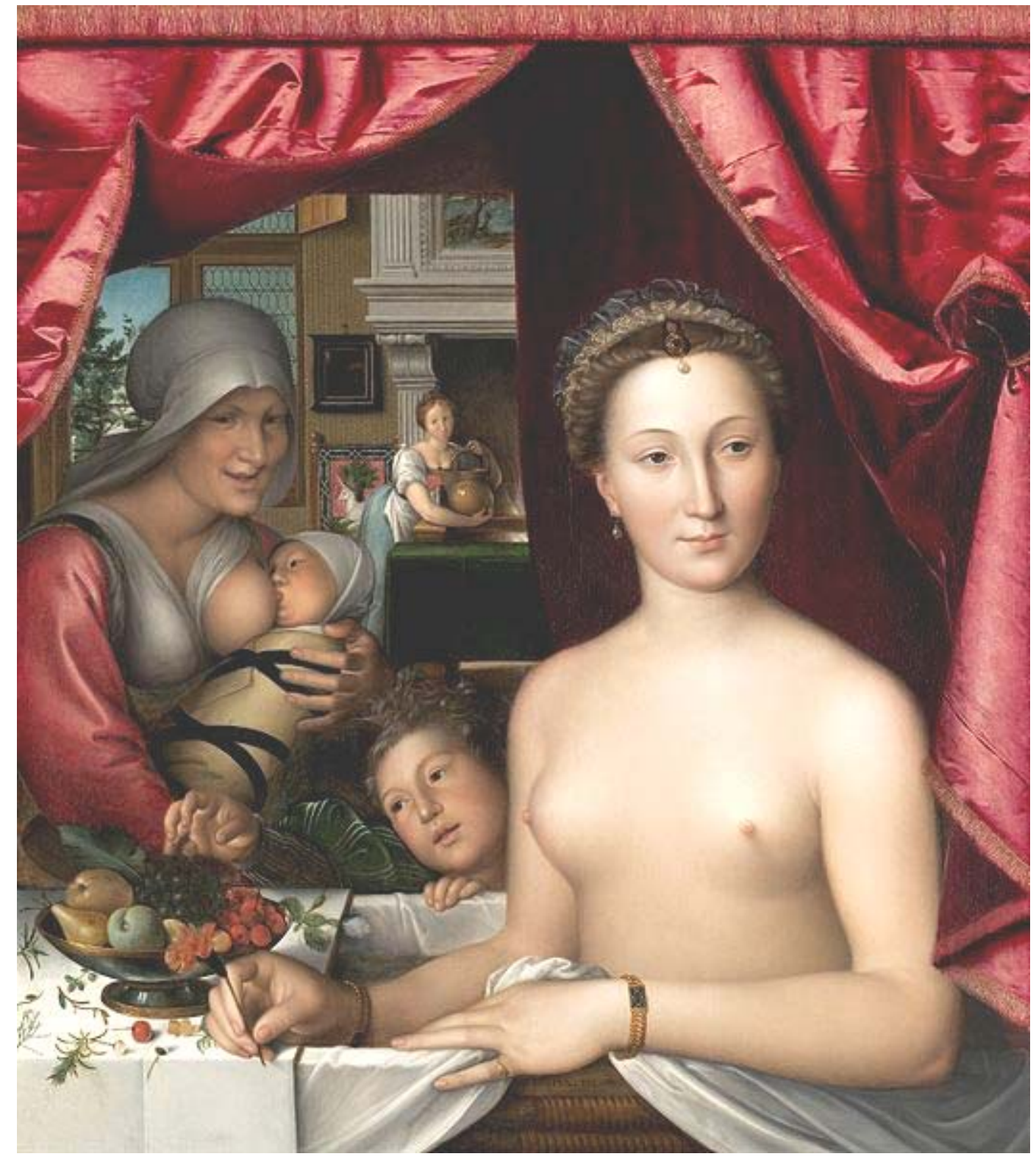

Fig. 1.10. François Clouet, A Lady in Her Bath, ca. 1571, oil on oak, National Gallery of Art, Washington D.C. 


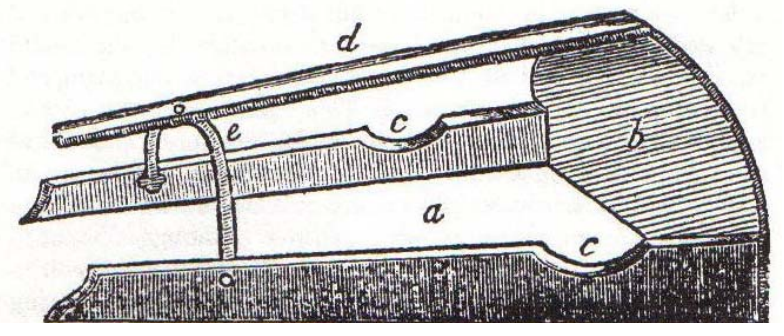

Fig. 1.11. The fifteenth-century Florentine Arruccio designed to prevent overlaying by the wet nurse.

a. Where the baby lies.

b. The headboard.

c. The hollows for the wet nurse's breasts.

d. Bar of wood to lean on when feeding.

e. Iron arch to support the bar.

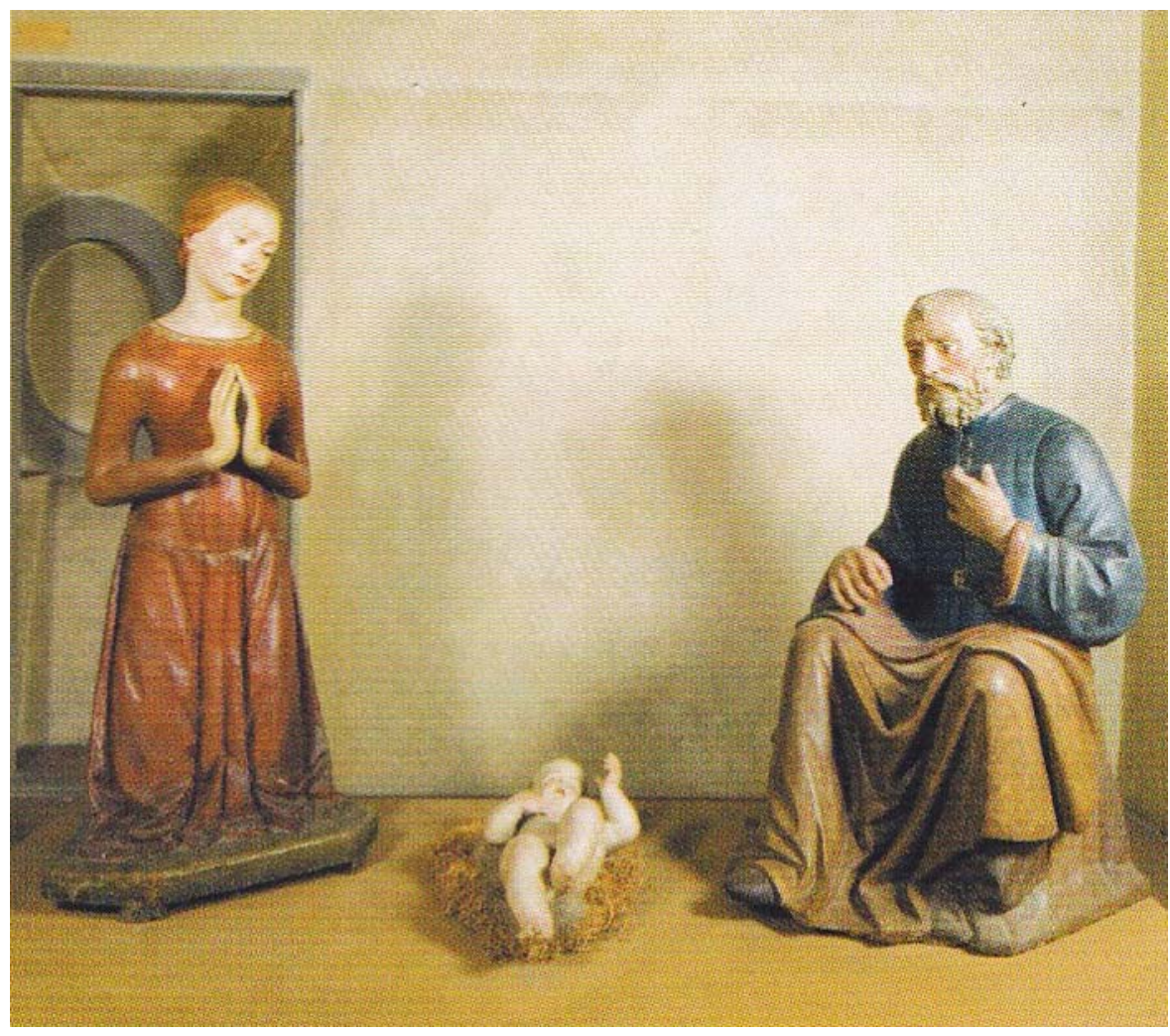

Fig. 1.12. Marco della Robbia called Frate Mattia, The Madonna and Saint Joseph, 1505, Institute of the Innocents, Florence. (The Christ Child statue is a later addition). 


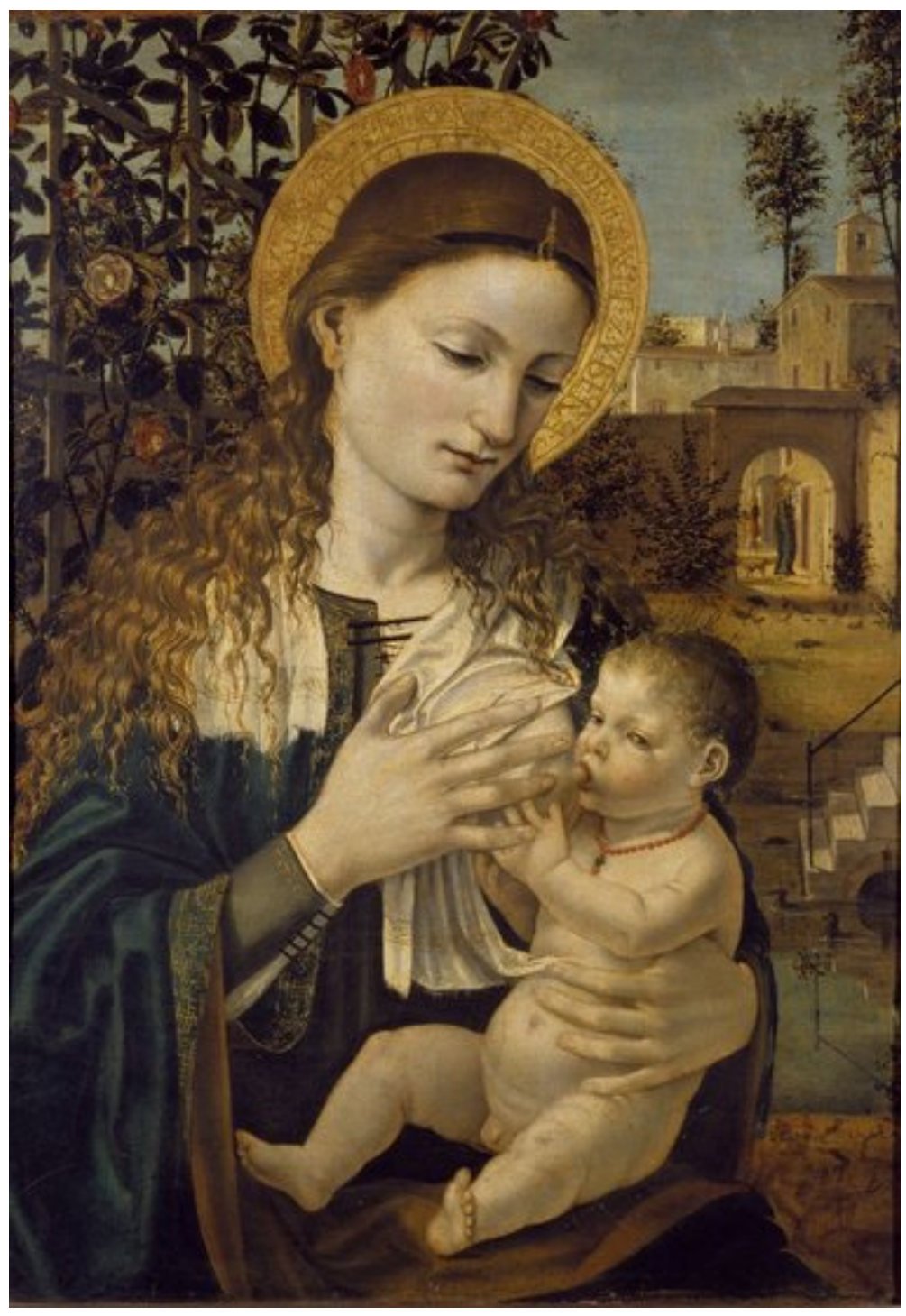

Fig. 1.14. Ambrogio da Fossono (Bergognone), Madonna del Latte, 1485, Accademia Carrara Bergamo 


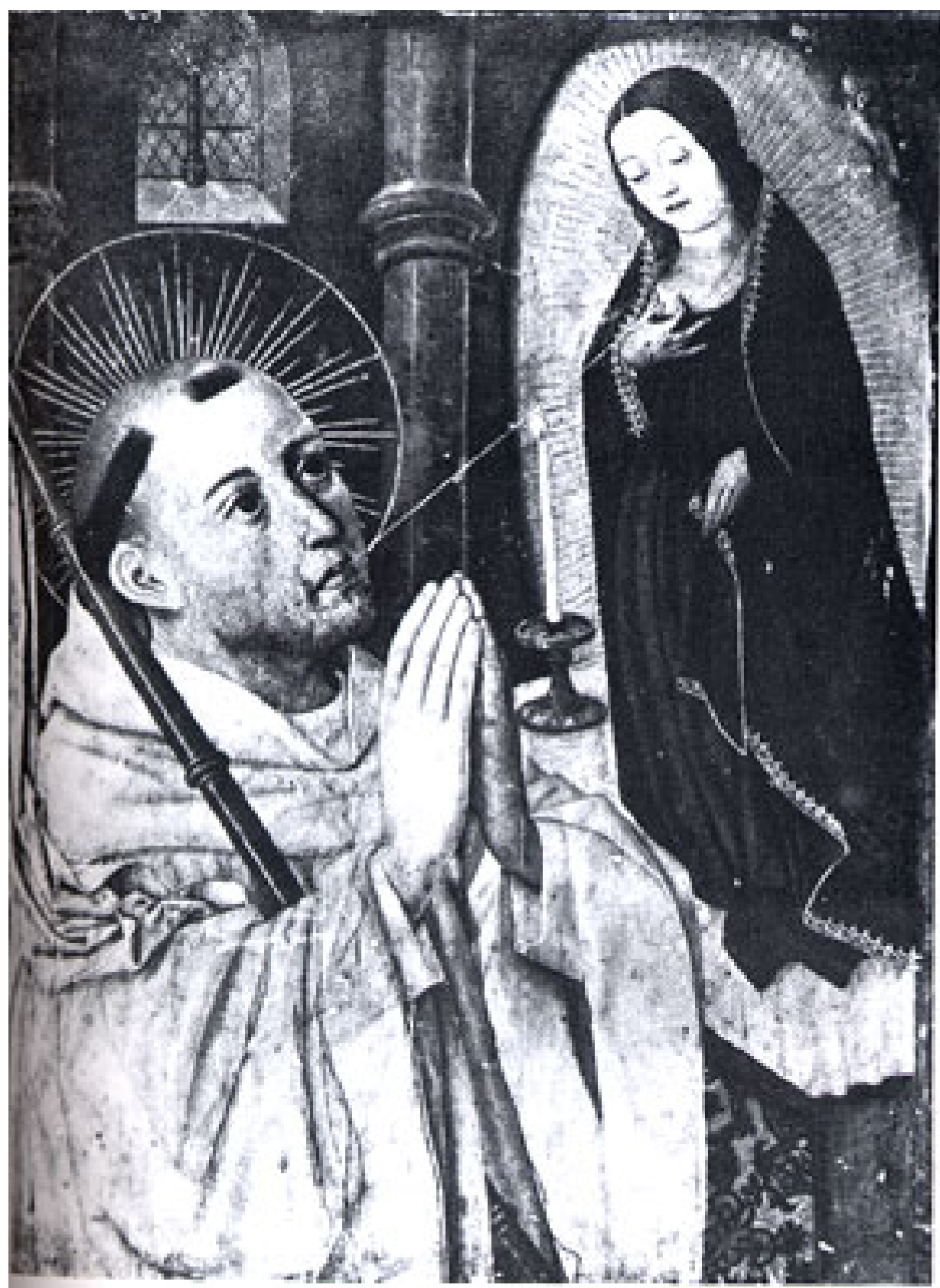

Fig. 2.1. Master of Osma, Lactation of St. Bernard from a Retable of St. Ildefonso, ca. 1460, The Cathedral, El Burgo de Osma, Soria. 


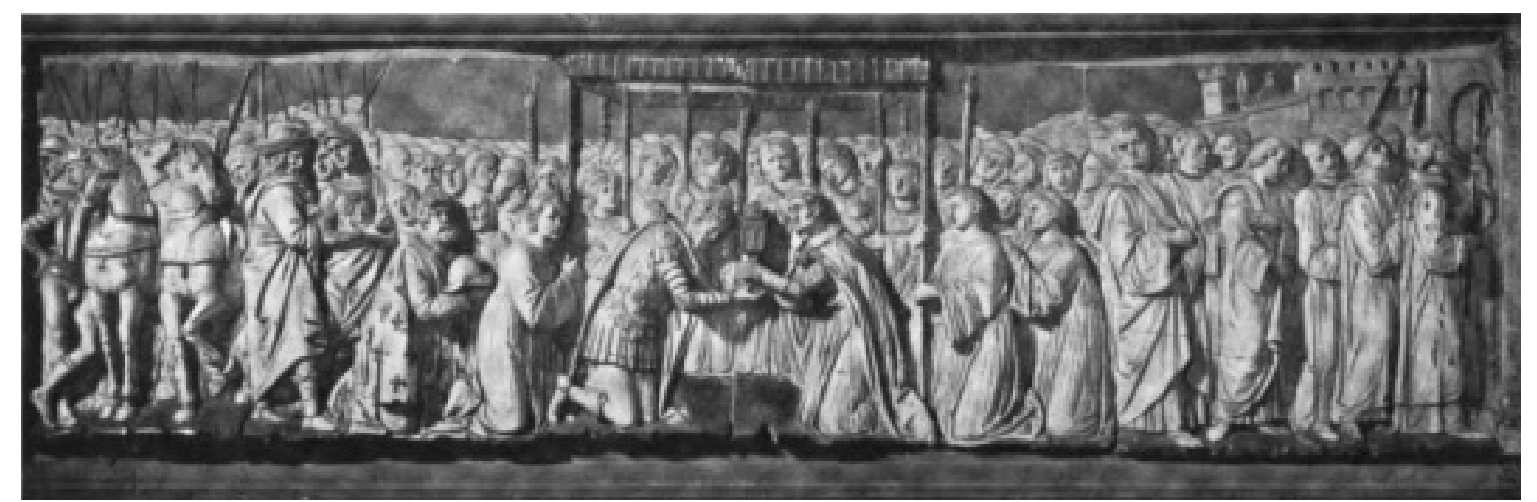

Fig. 2.2. Andrea della Robbia, Historical Relief, Collegiata di S. Lorenzo, Montevarchi.

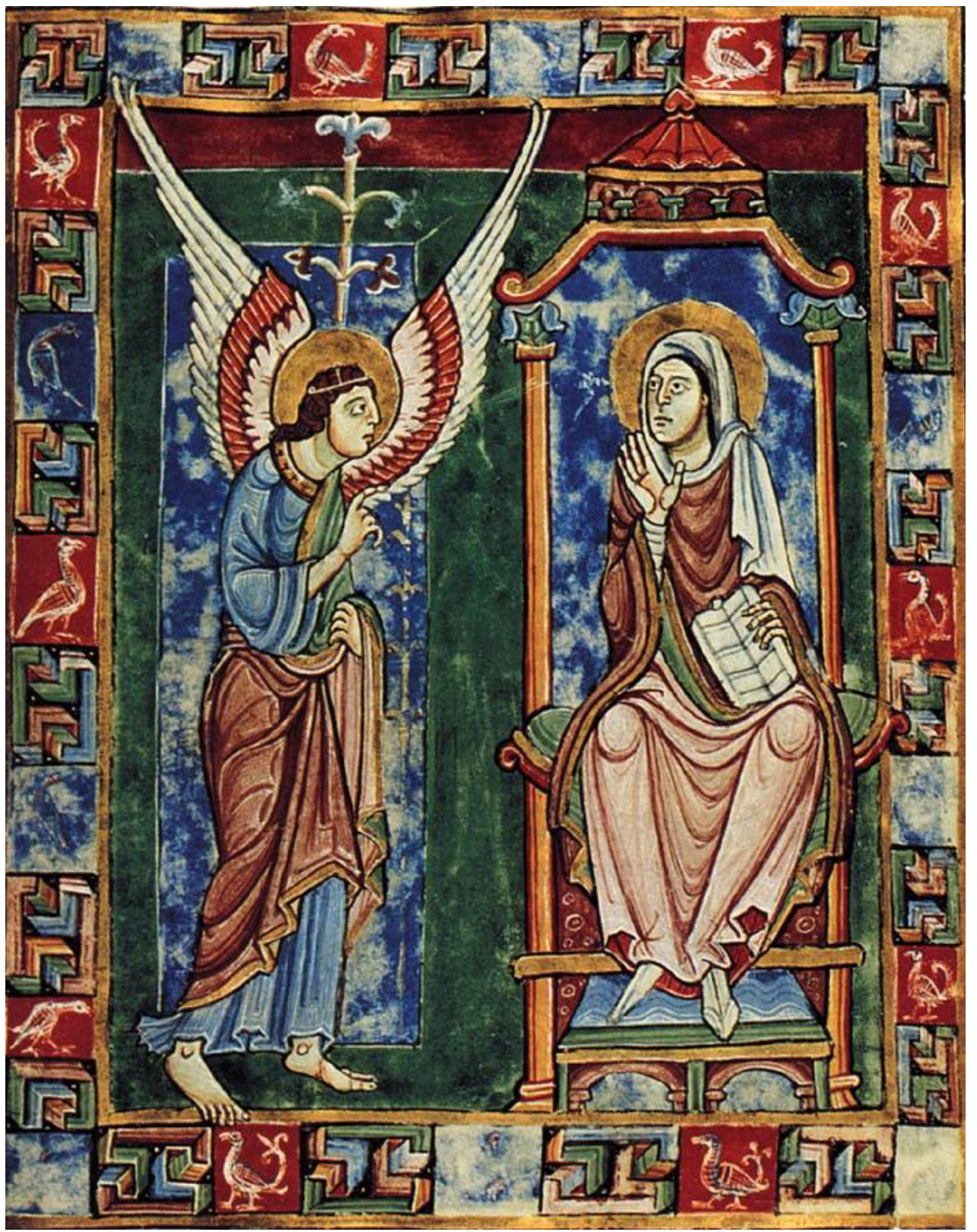

Fig. 2.3. The Annunciation, 1120s, St. Albans Psalter. 


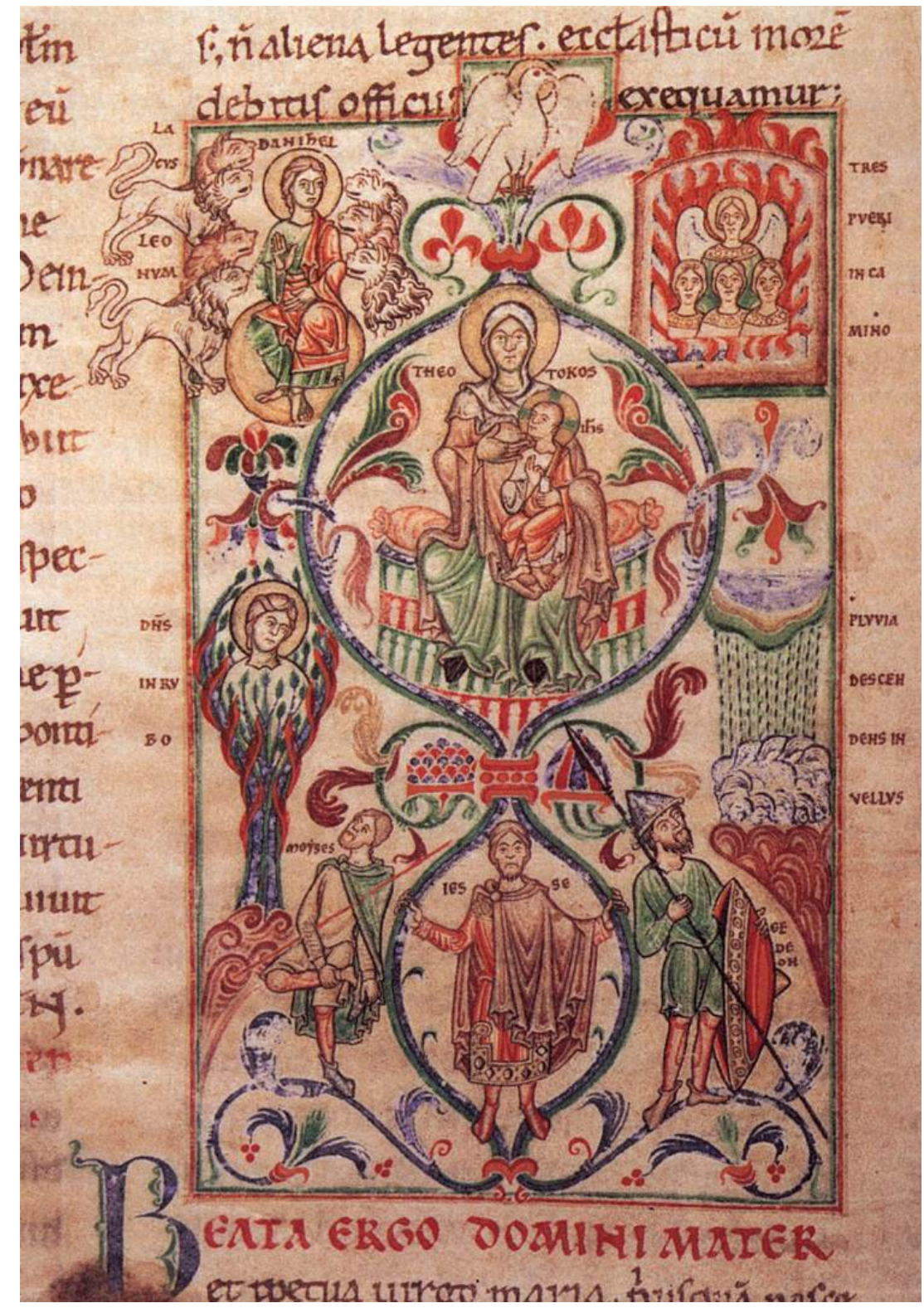

Fig. 2.4. Tree of Jesse, c. 1130, Colored ink drawing, Bibliothèque Municipale, Dijon. 


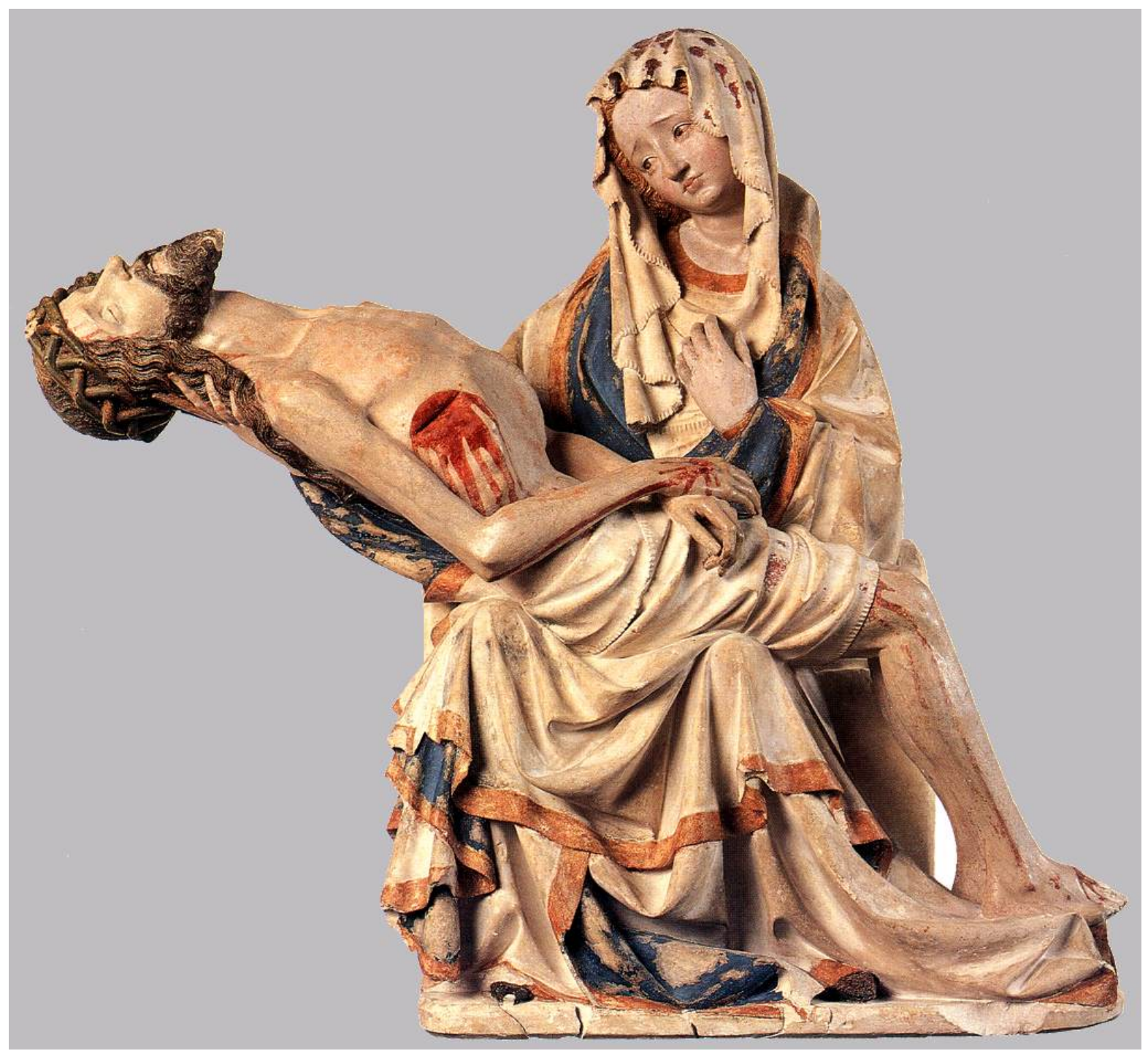

Fig. 2.5. Pietà, ca. 1400, Limestone. Seeon Monastery, Salzburg. 


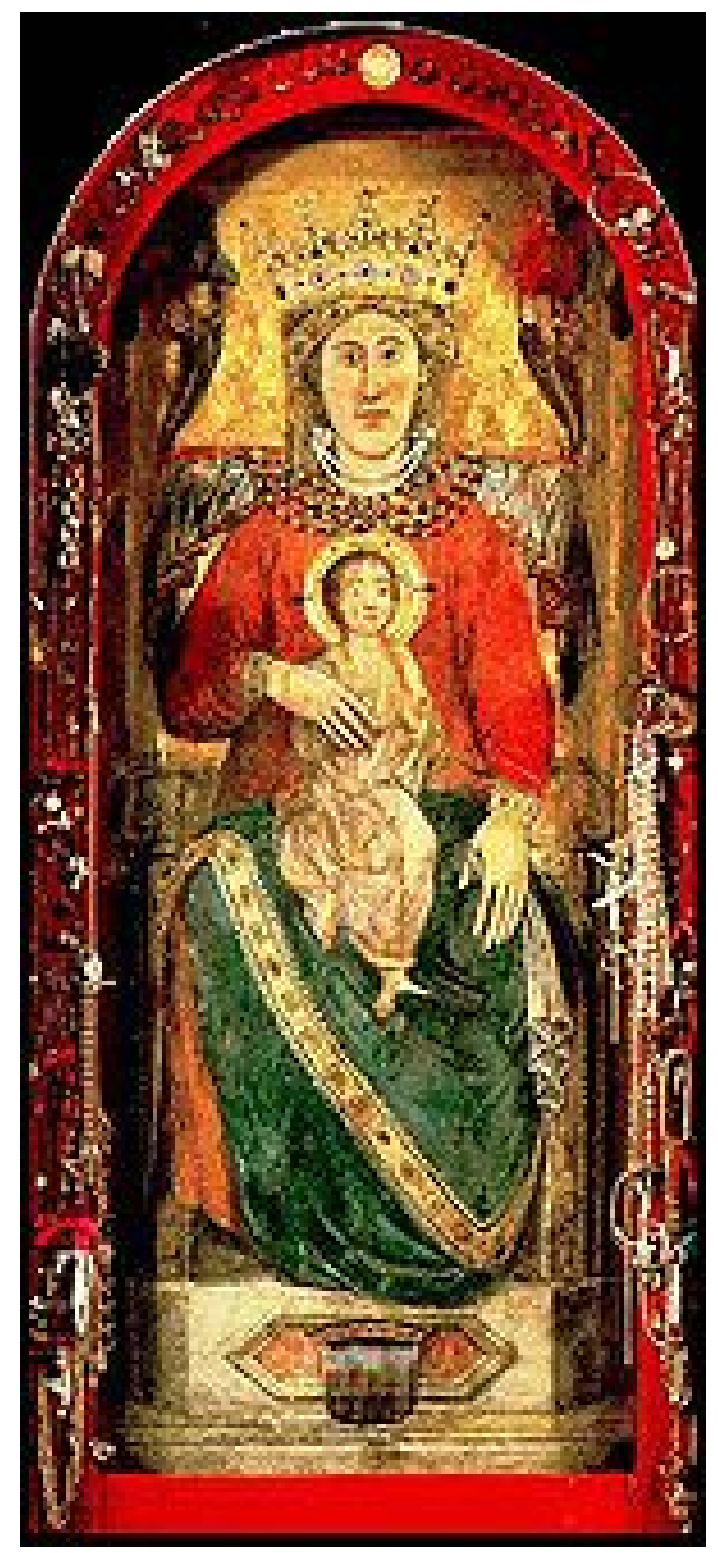

Fig. 2.6. Our Lady of Impruneta, ca. 1430, Santa Maria dell'Impruneta, near Florence. 


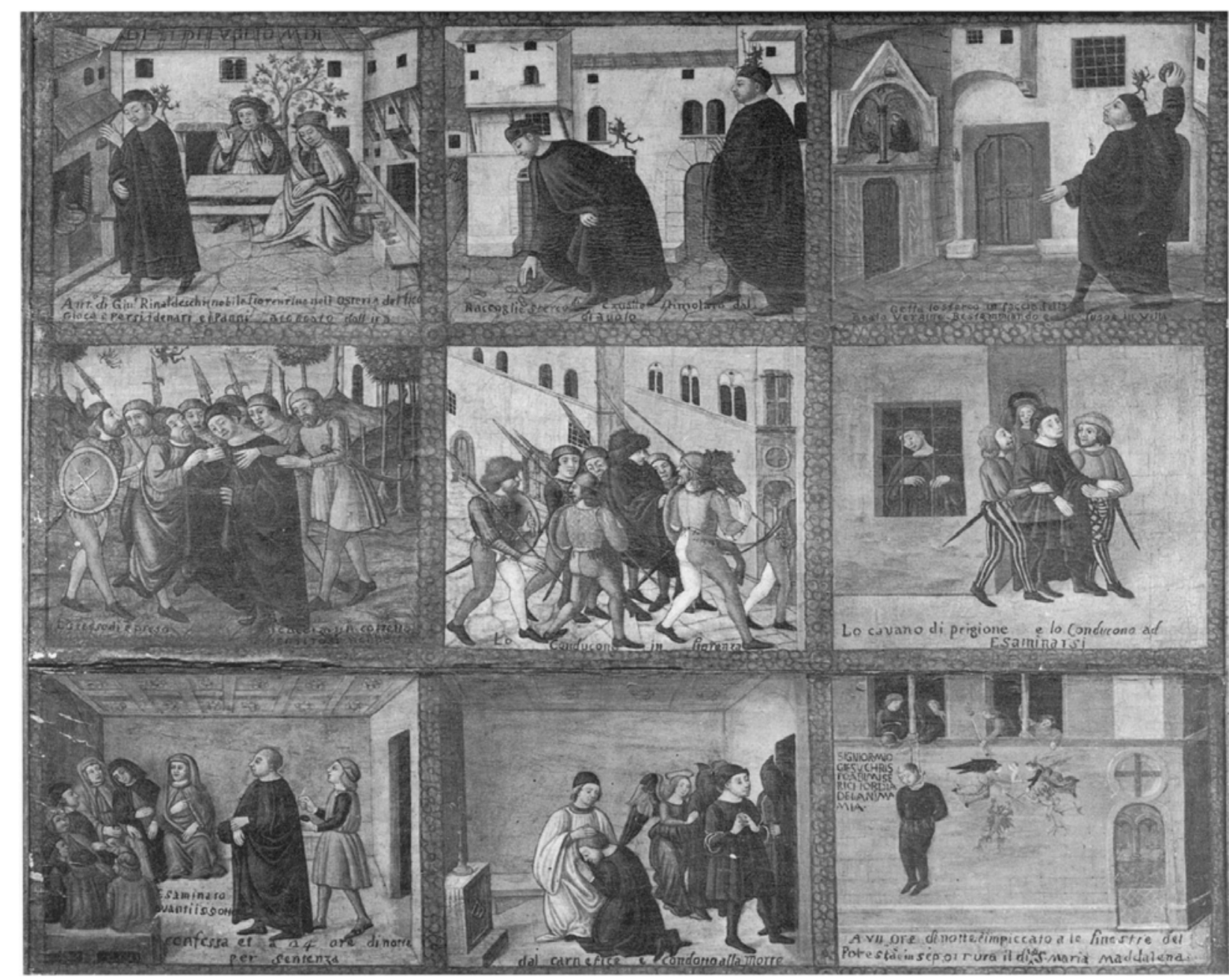

Fig. 2.7. Filippo Dolciati, The History of Antonio Rinaldeschi, 1502, Museo Stibbert, Florence. 


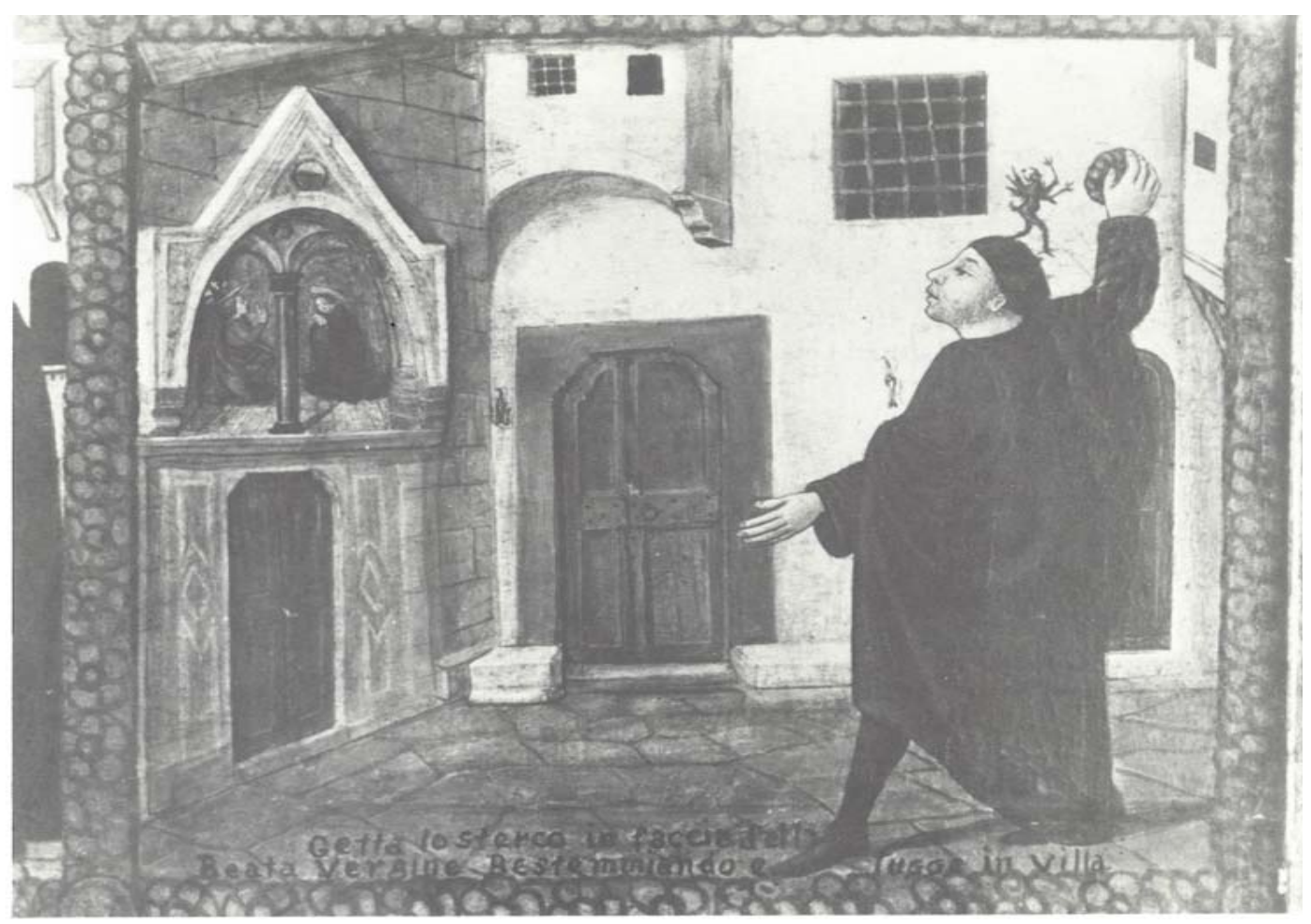

Fig. 2.8. Filippo Dolciati, The History of Antonio Rinaldeschi, detail, 1502, Museo Stibbert, Florence. 


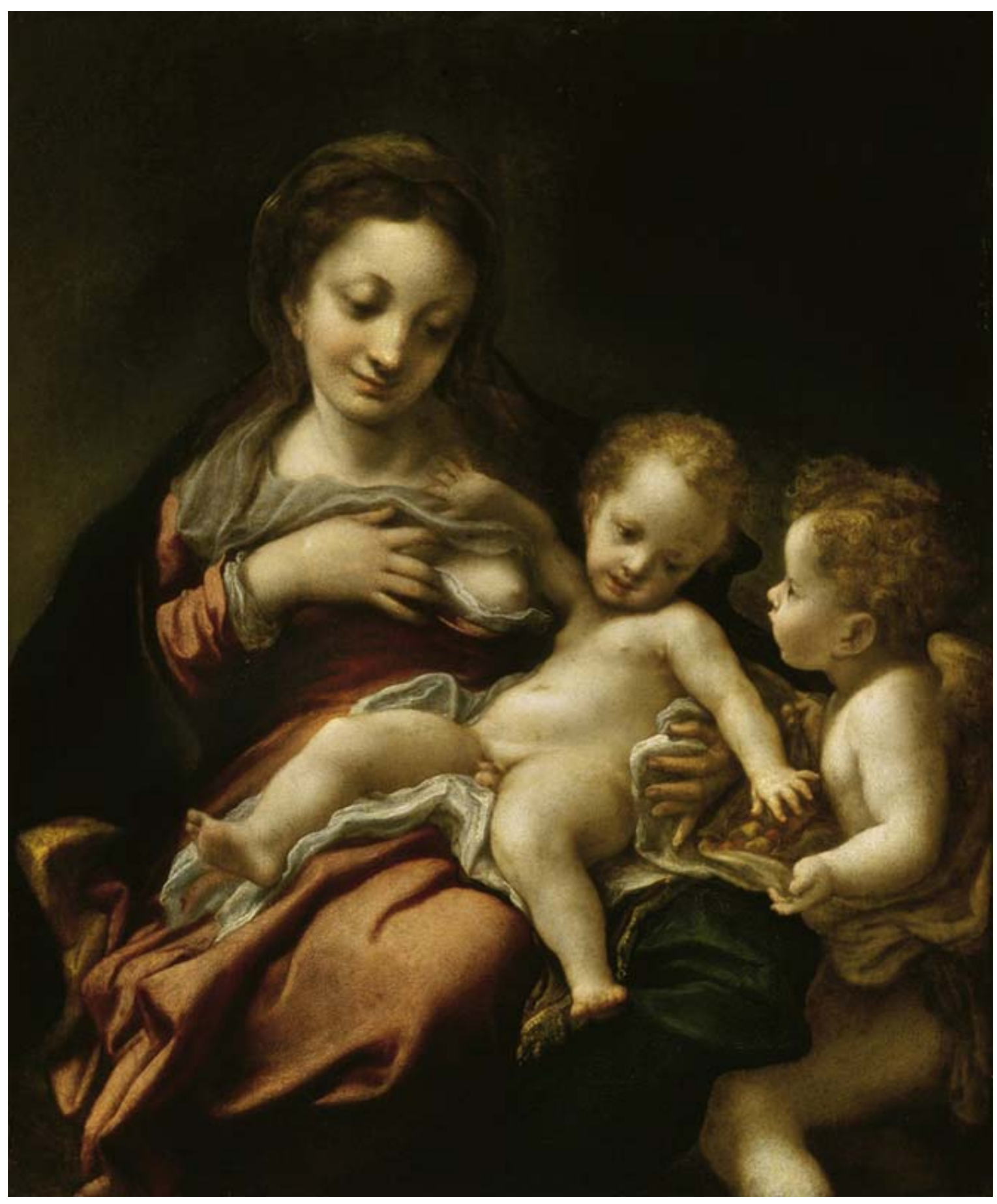

Fig. 2.9. Correggio, Madonna and Child with an Angel, ca. 1525, oil on panel, Museum of Fine Arts, Budapest. 


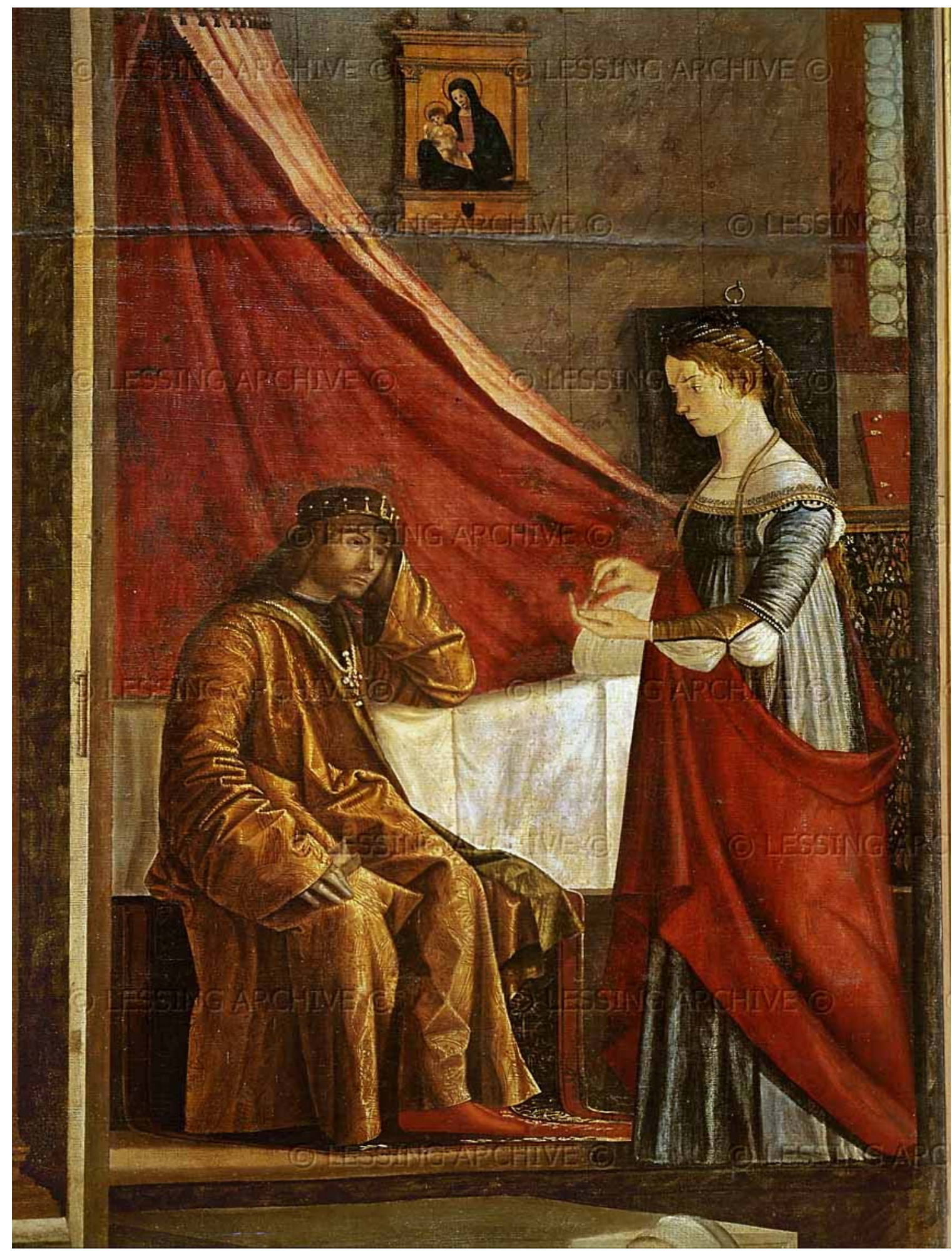

Fig. 2.10. Vittorio Carpaccio, Scenes from the Life of St. Ursula: Arrival of the Ambassadors (detail), 1495, Gallerie dell'Accademia, Venice. 


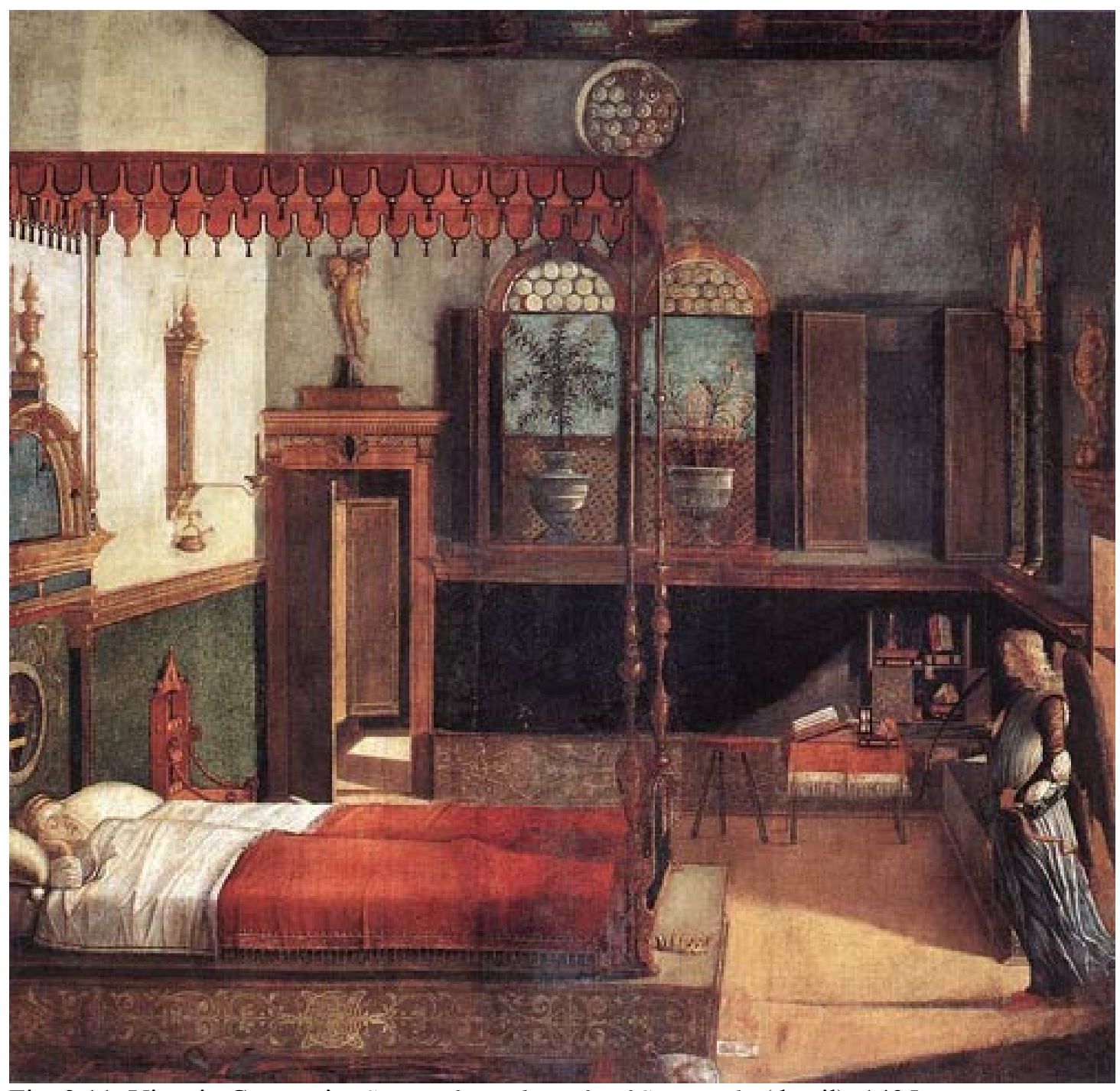

Fig. 2.11. Vittorio Carpaccio, Scenes from the Life of St. Ursula (detail), 1495, Gallerie dell'Accademia,Venice.

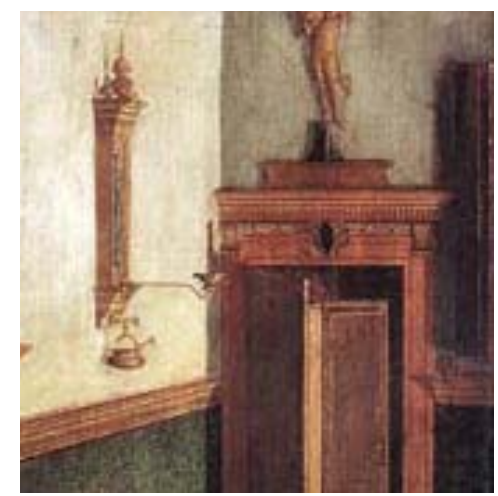

Fig. 2.12. Vittorio Carpaccio, Scenes from the Life of St. Ursula, detail of tabernacle frame. 


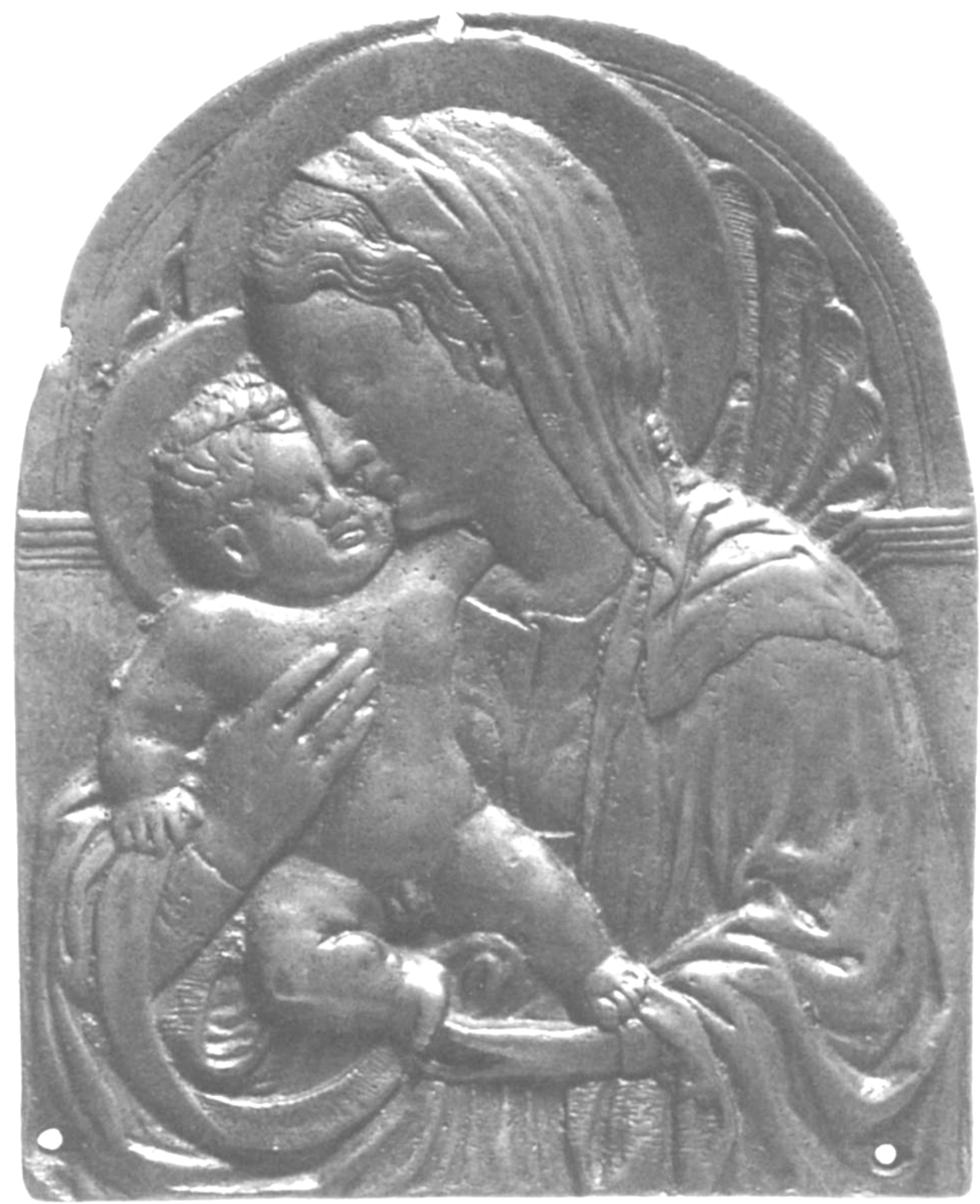

Fig. 2.13. Donatello circle, Madonna and Child before a Niche, 1440s, bronze plaquette, Walters Art Museum, Baltimore. 


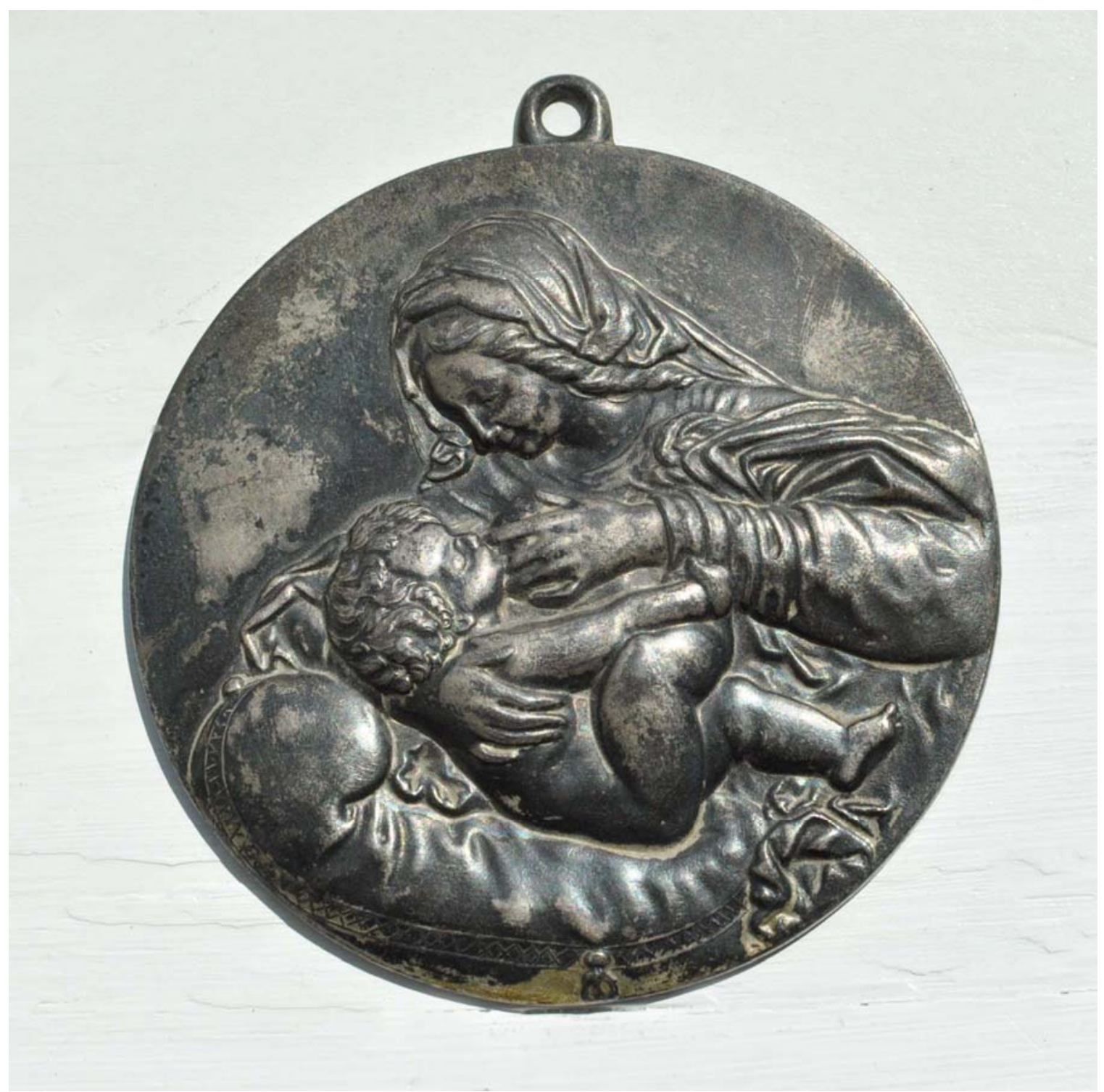

Fig. 2.14. Artist unknown, after Andrea Solario's Madonna with Green Cushion, private collection. 


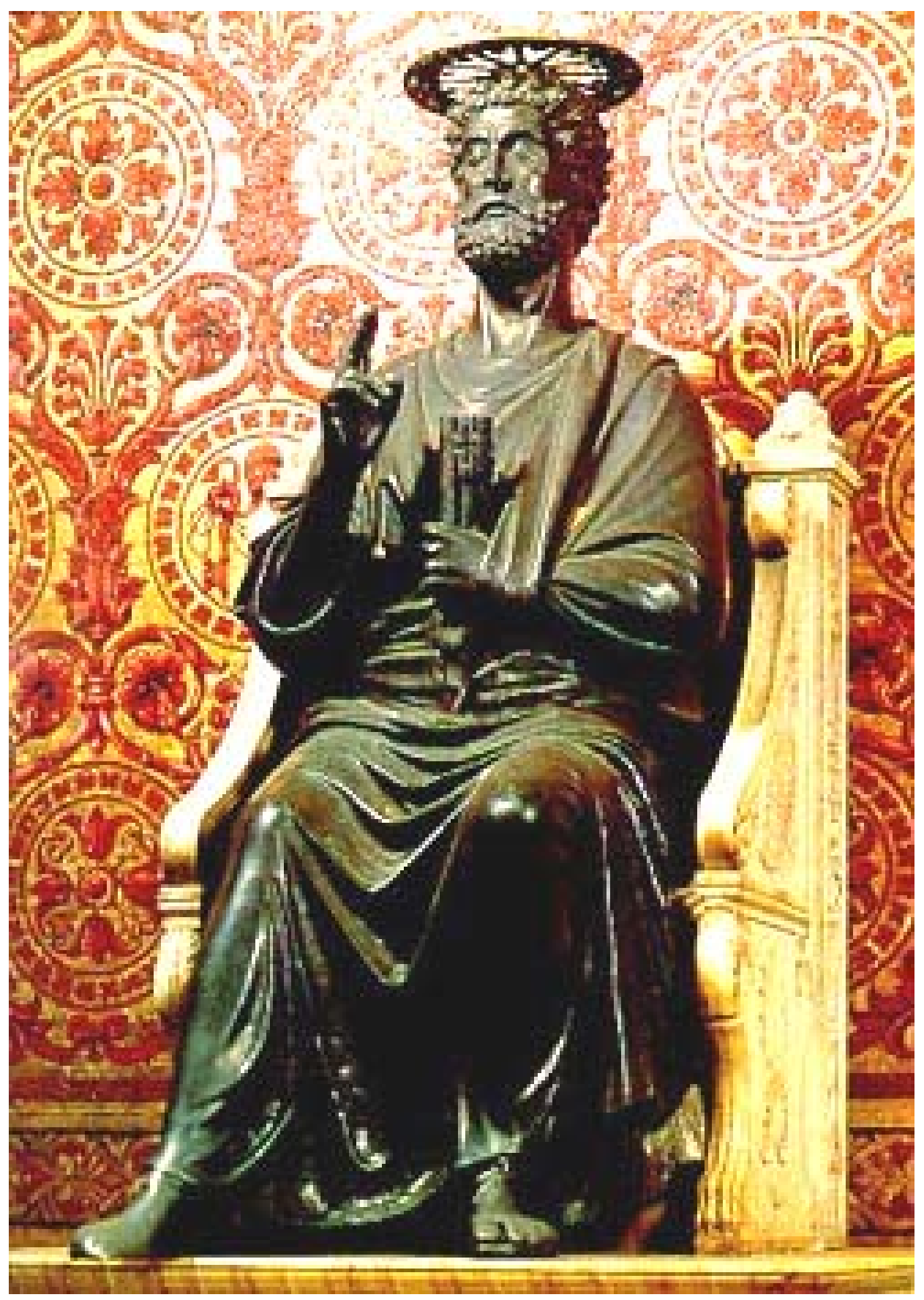

Fig. 2.15. Attributed to Arnolfo di Cambio, St. Peter, ca. 1300, bronze, St. Peter Basilica, Rome. 


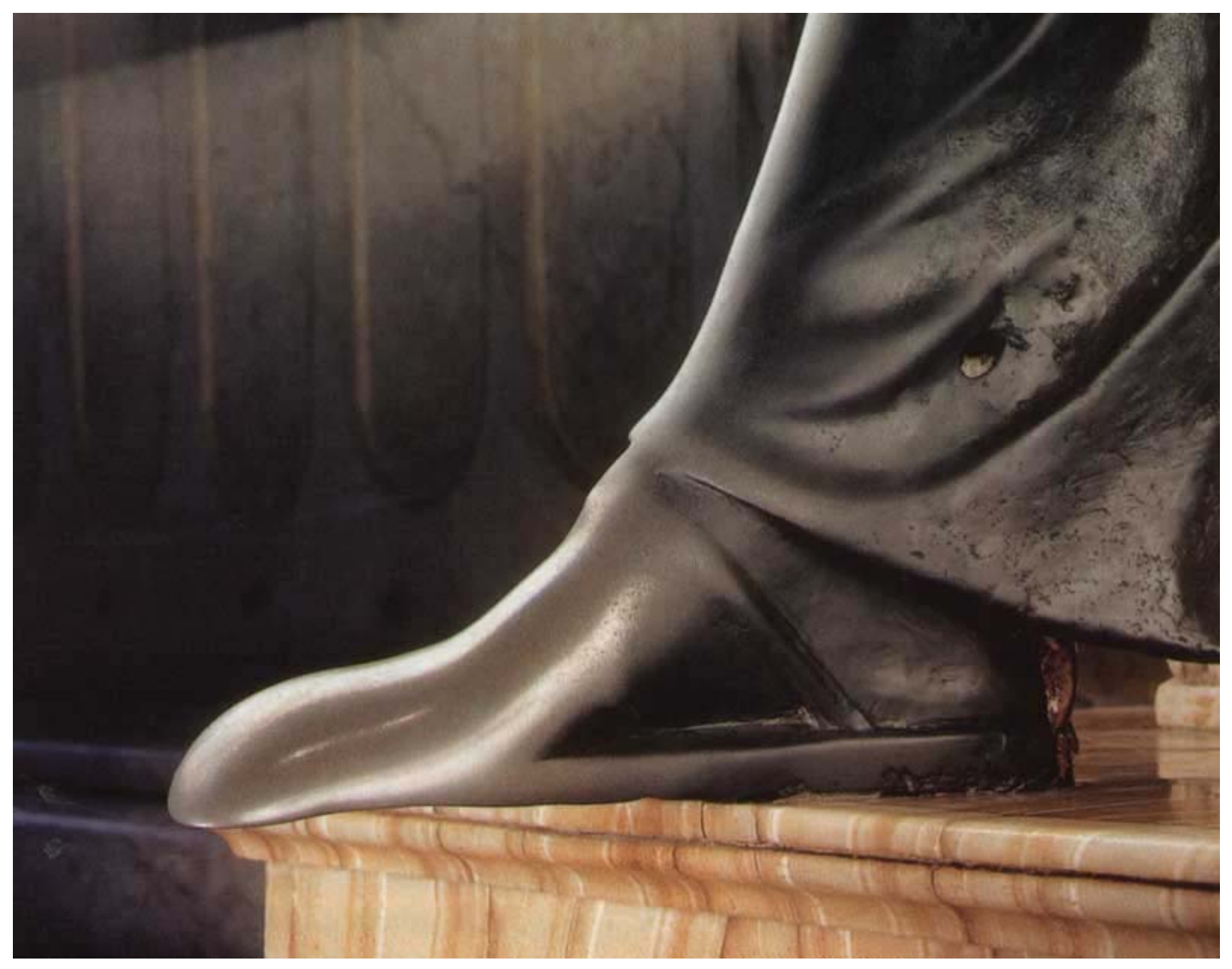

Fig. 2.16. Attributed to Arnolfo di Cambio, St. Peter, detail, ca. 1300, bronze, St. Peter Basilica, Rome. 


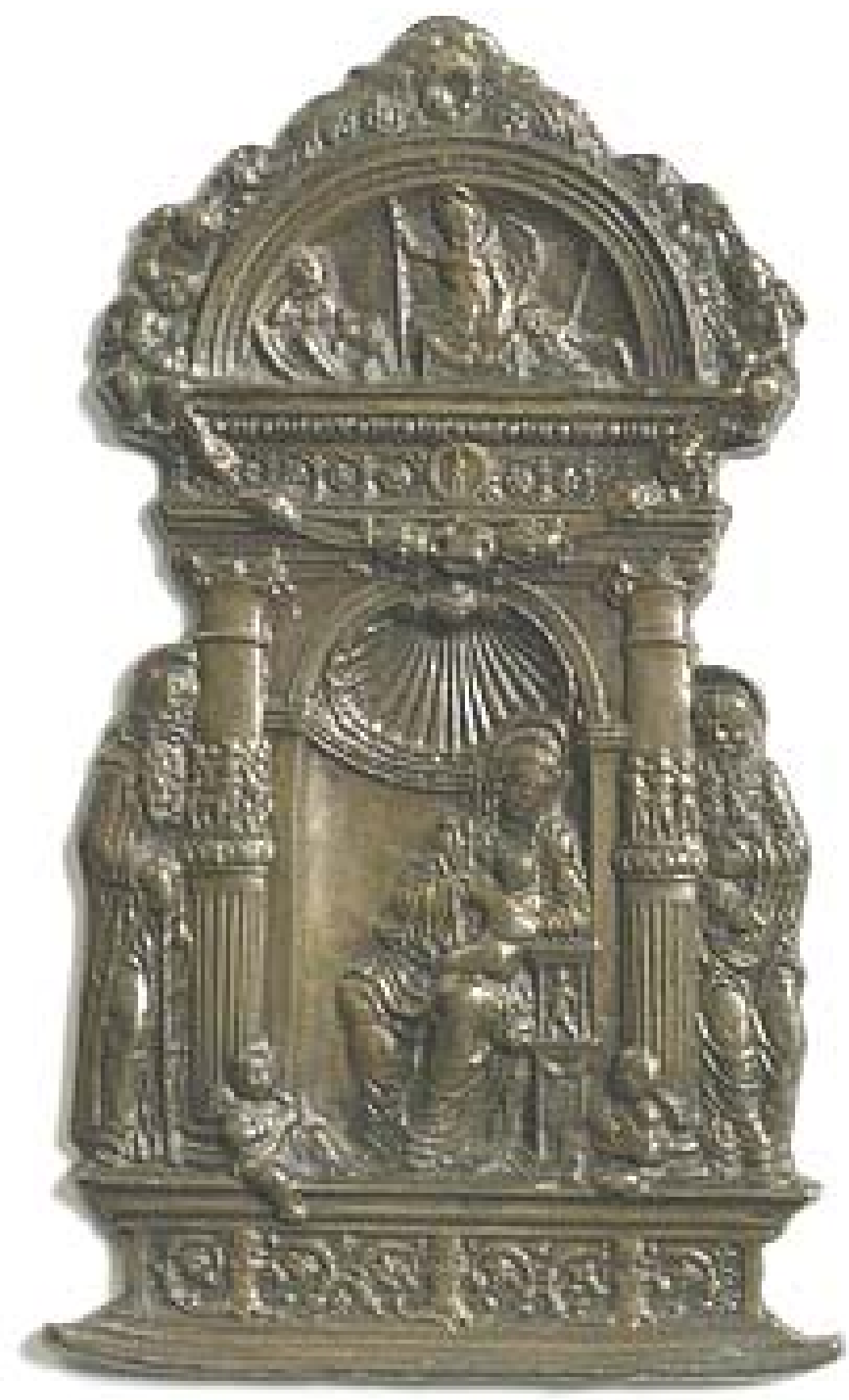

Fig. 2.17. Moderno, Virgin and Child with St. Anthony Abbot and St. Jerome, ca. 1490, bronze pax, Victoria and Albert Museum, London. 


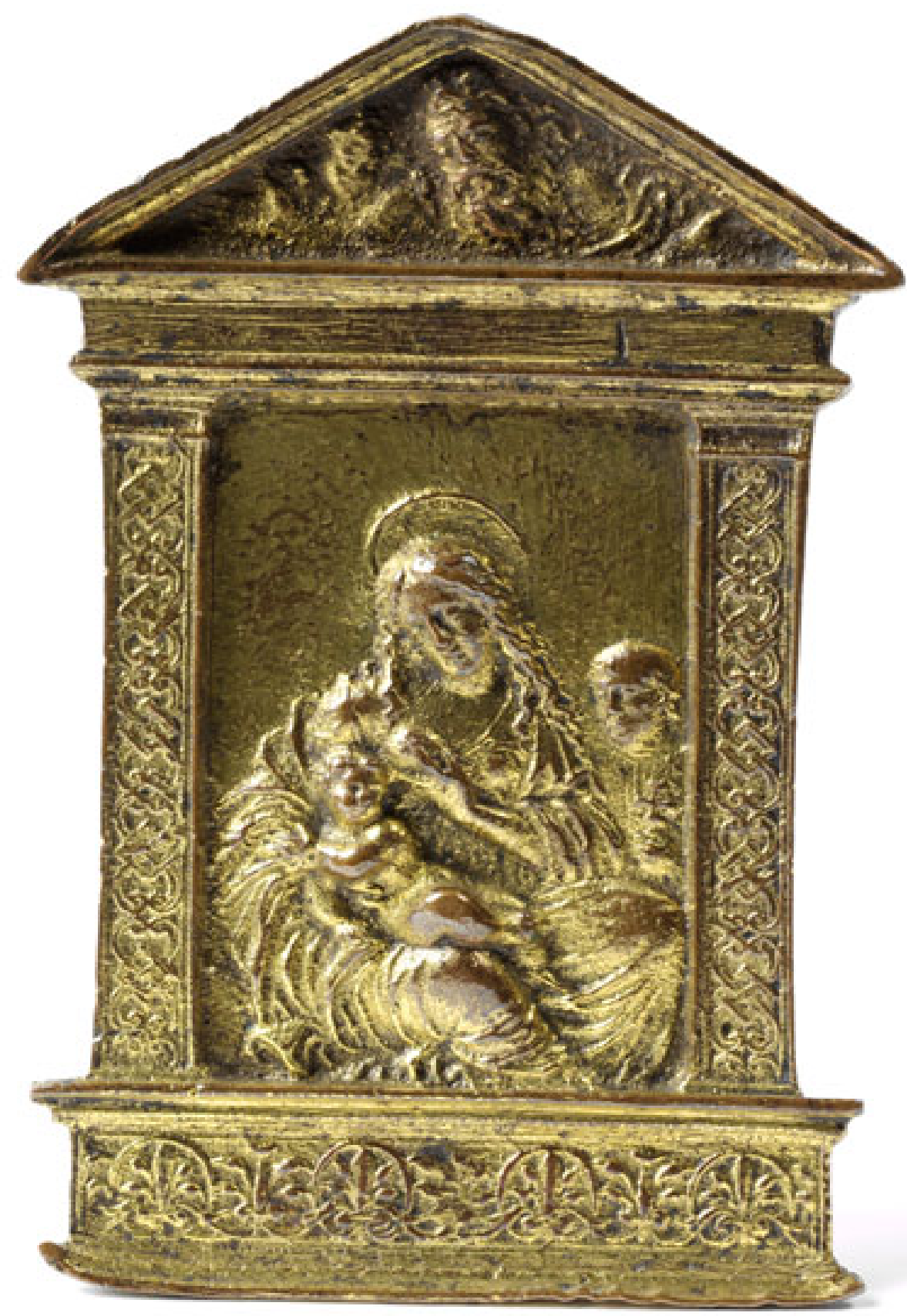

Fig. 2.18. Moderno, Madonna and Child with Donor, Tympanum with God and Cherub, early sixteenth century, bronze pax, The British Museum, London. 


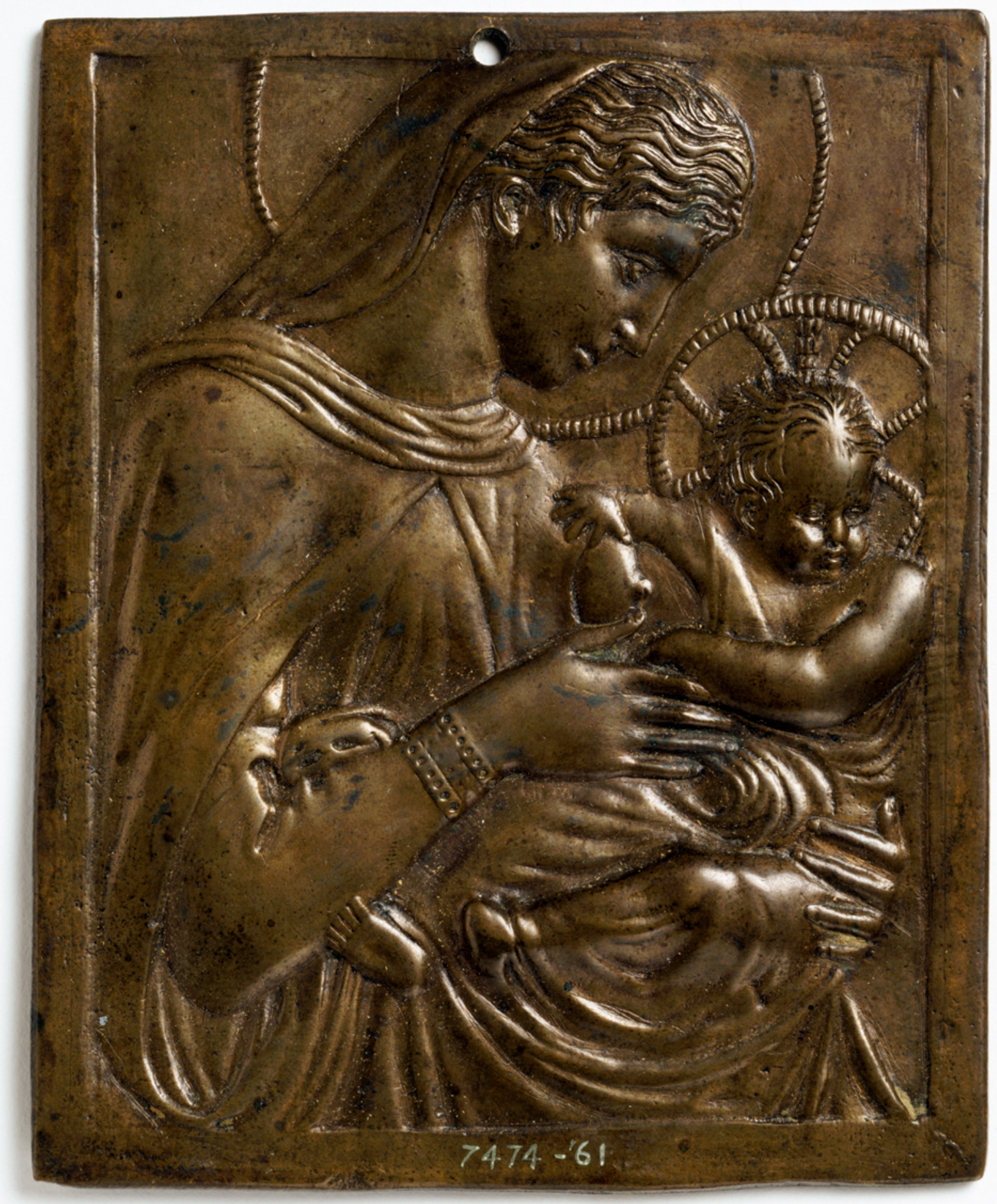

Fig. 2.19. Attributed to Donatello. Madonna del Latte, bronze. 


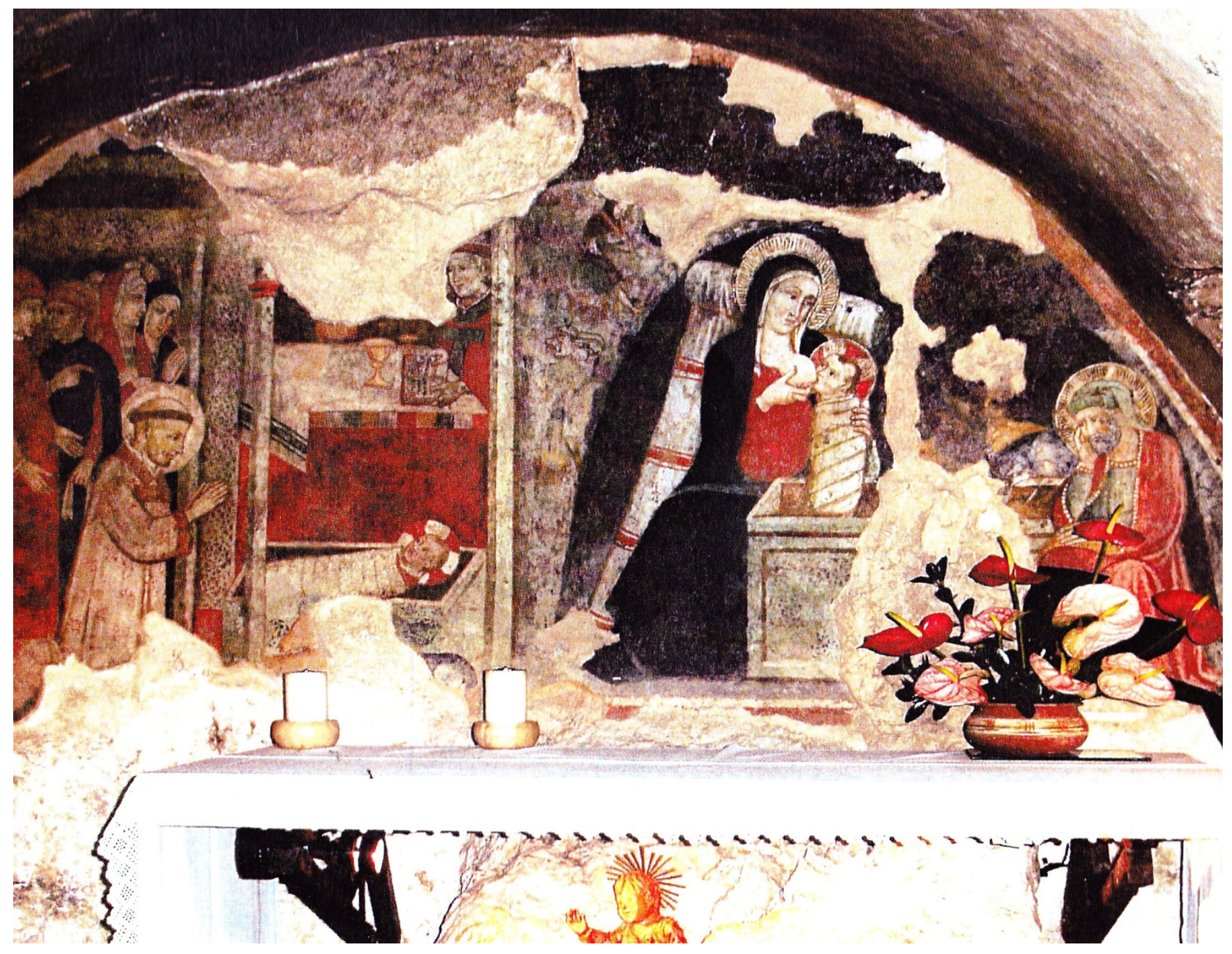

Fig. 3.1. Artist Unknown, Franciscan Crib with the Madonna del Latte, fourteenth century fresco, Grotto in Greccio, near Rieti. 


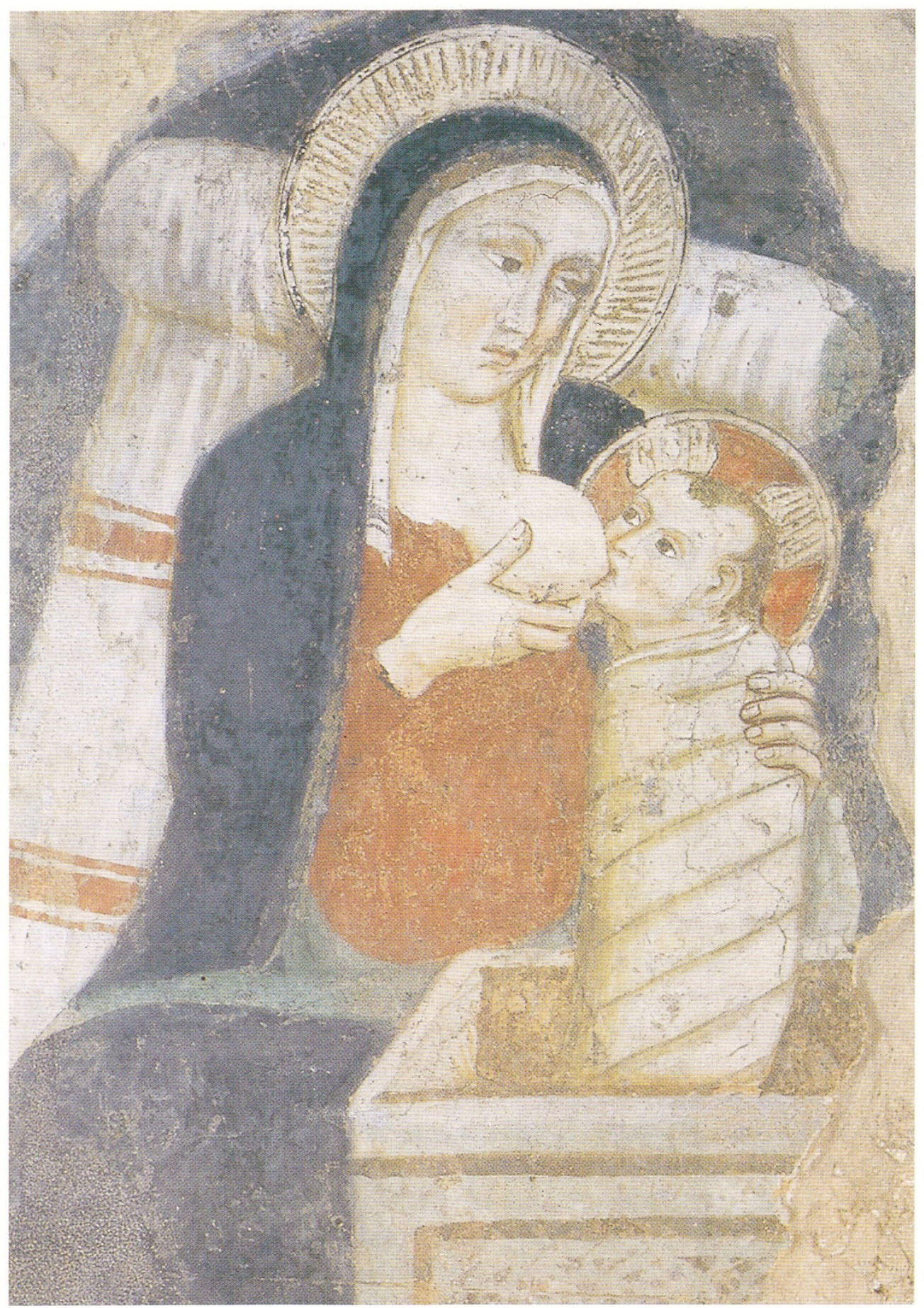

Fig. 3.2. Artist Unknown, detail of Franciscan Crib with the Madonna del Latte. 


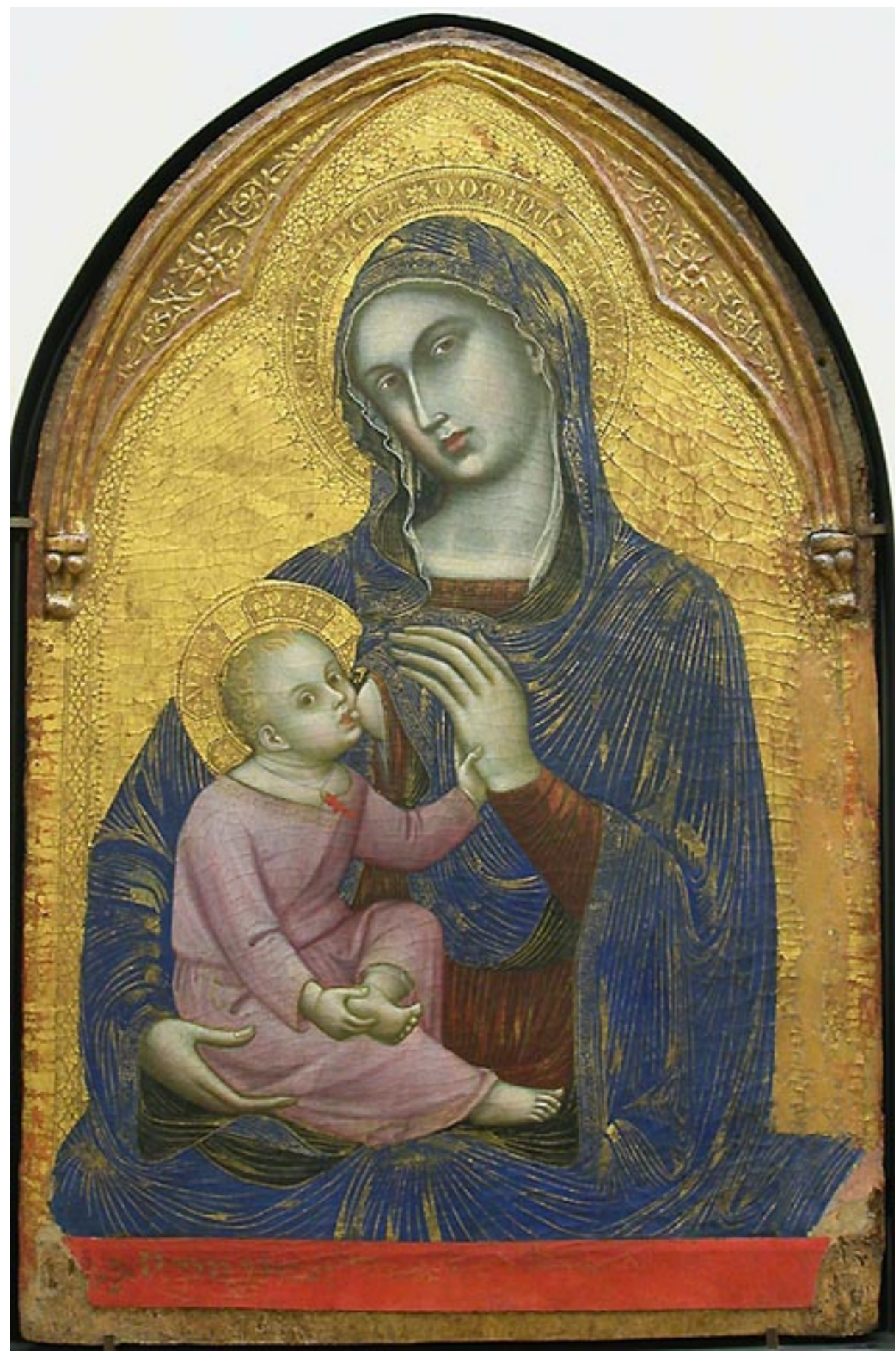

Fig. 3.3. Barnaba da Modena, Virgin with Child, ca. 1370, wood, central panel of polyptych, The Louvre, Paris. 


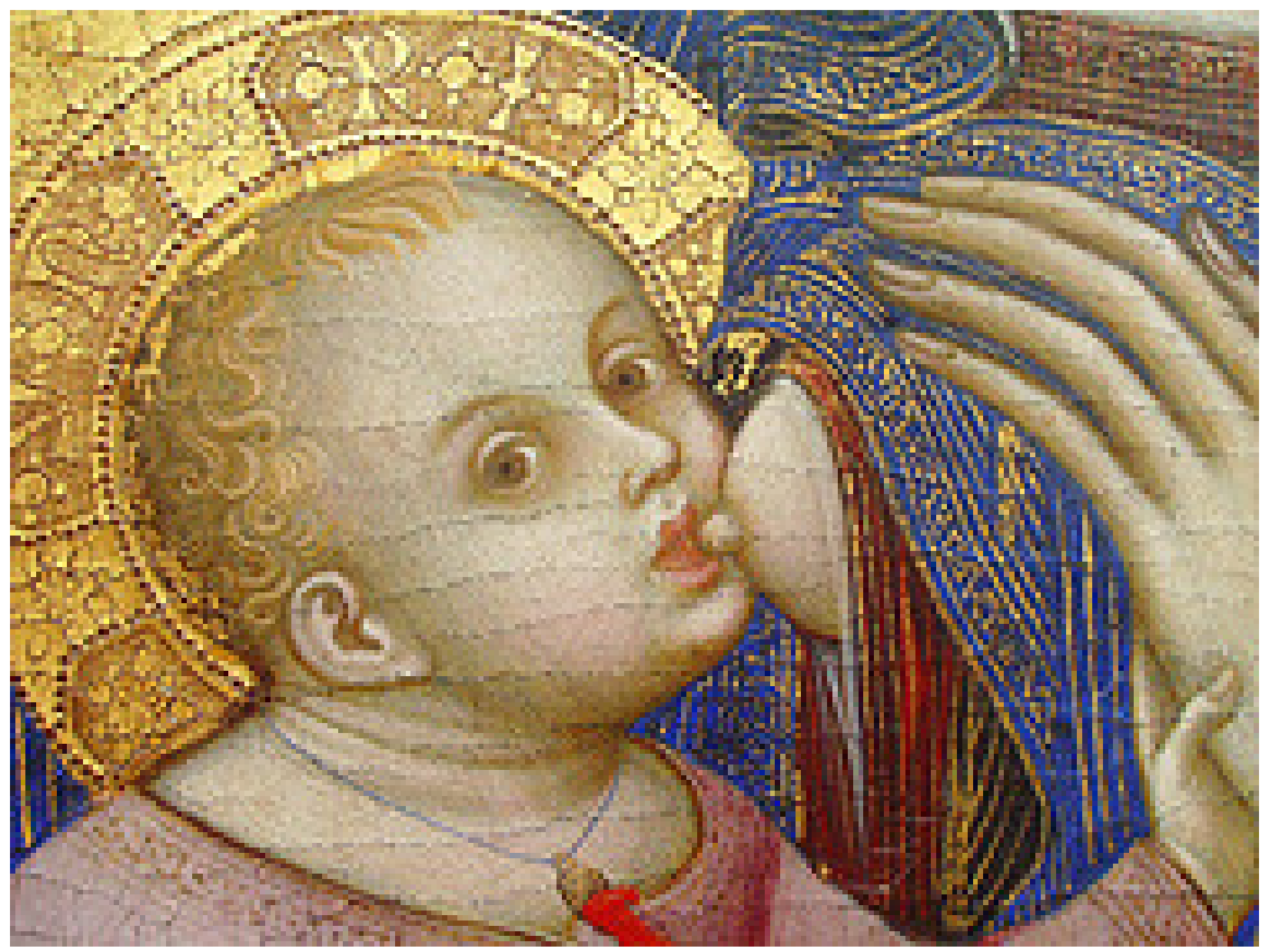

Fig. 3.4. Barnaba da Modena, detail of Virgin with Child. 


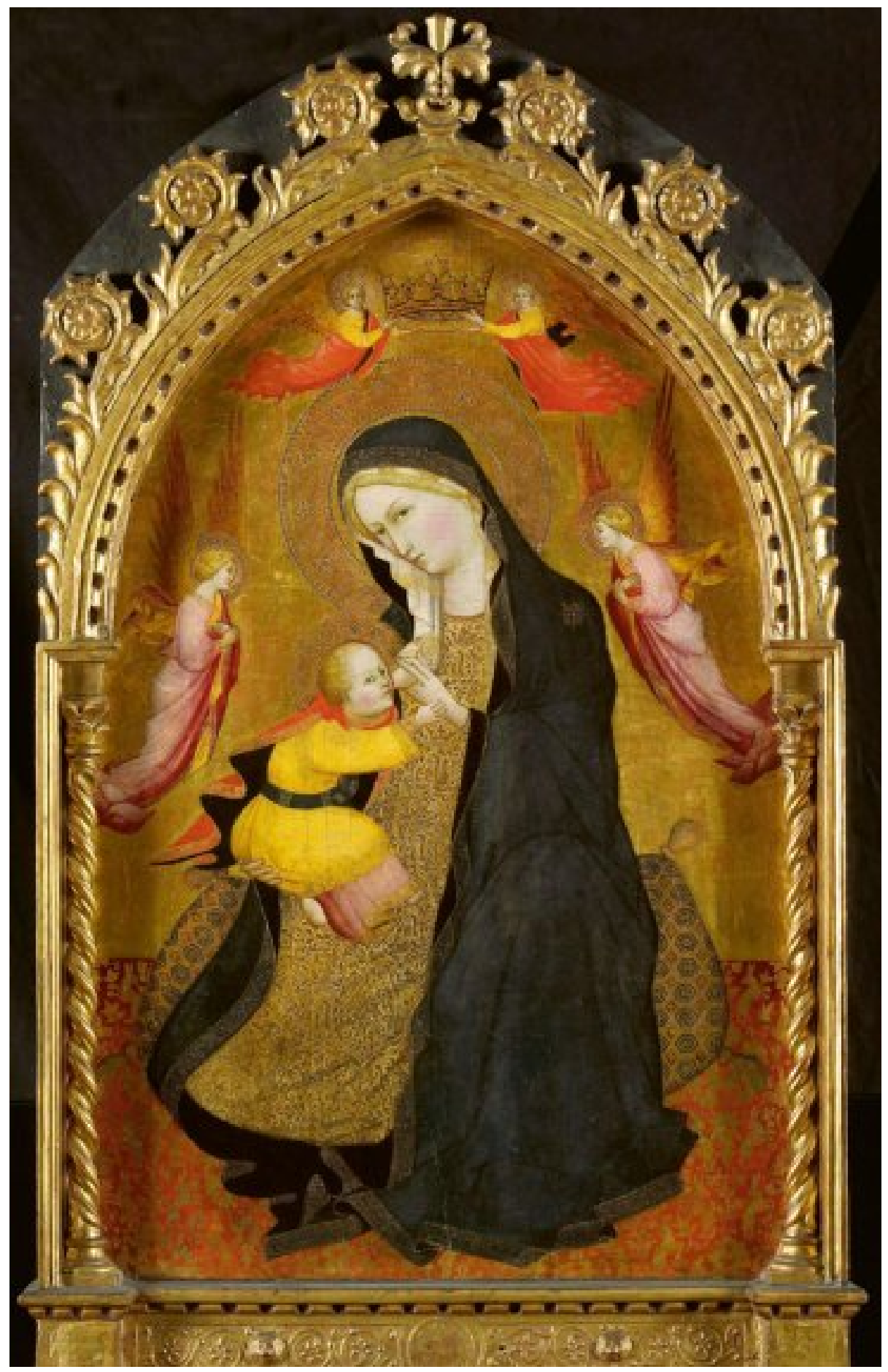

Fig. 3.5. Agnolo Gaddi, Madonna and Child, ca. 1390, oil on panel, Rijksmuseum. 


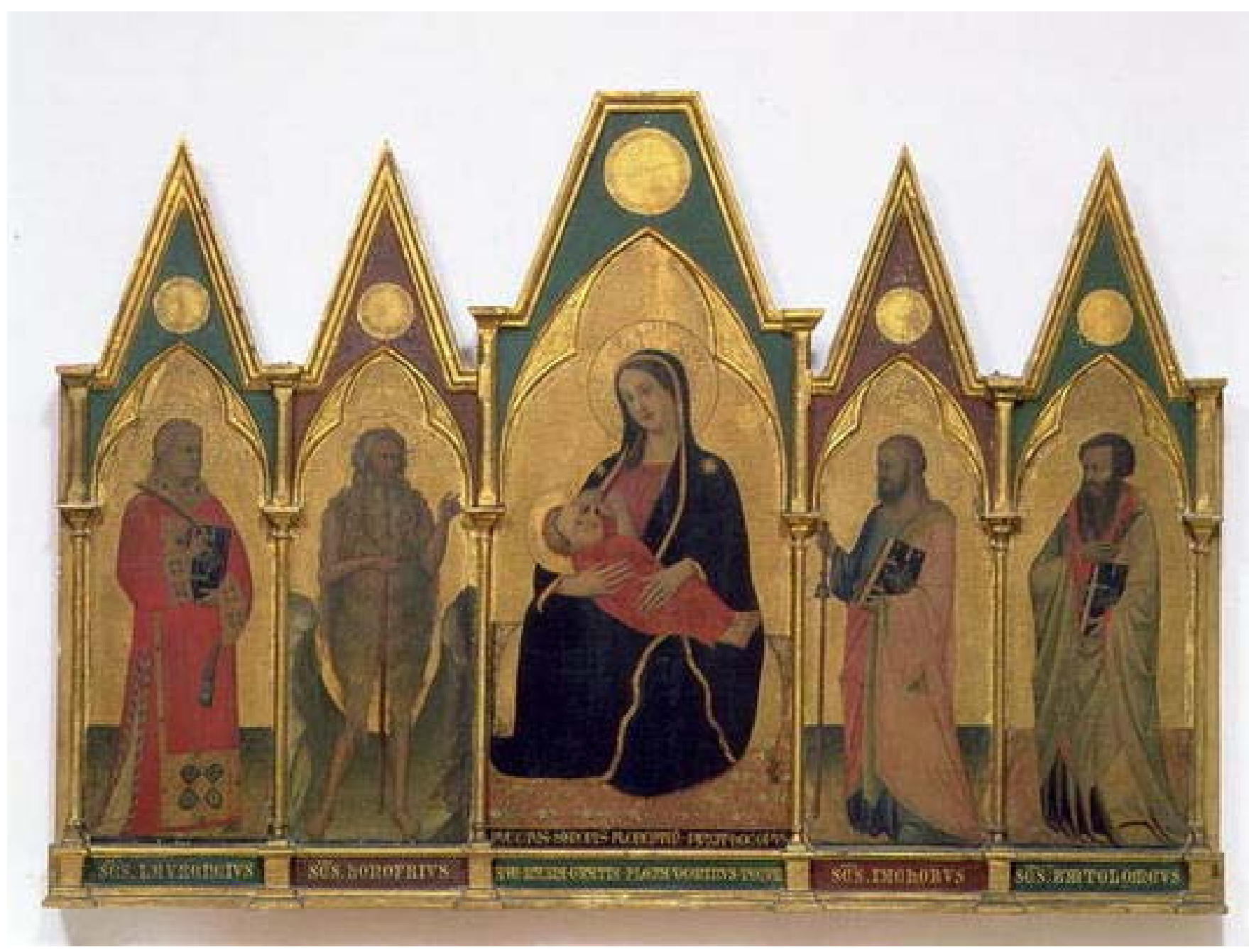

Fig. 3.6. Puccio di Simone, Madonna of Humility, mid-fourteenth century, Polyptych, Accademia, Florence. 


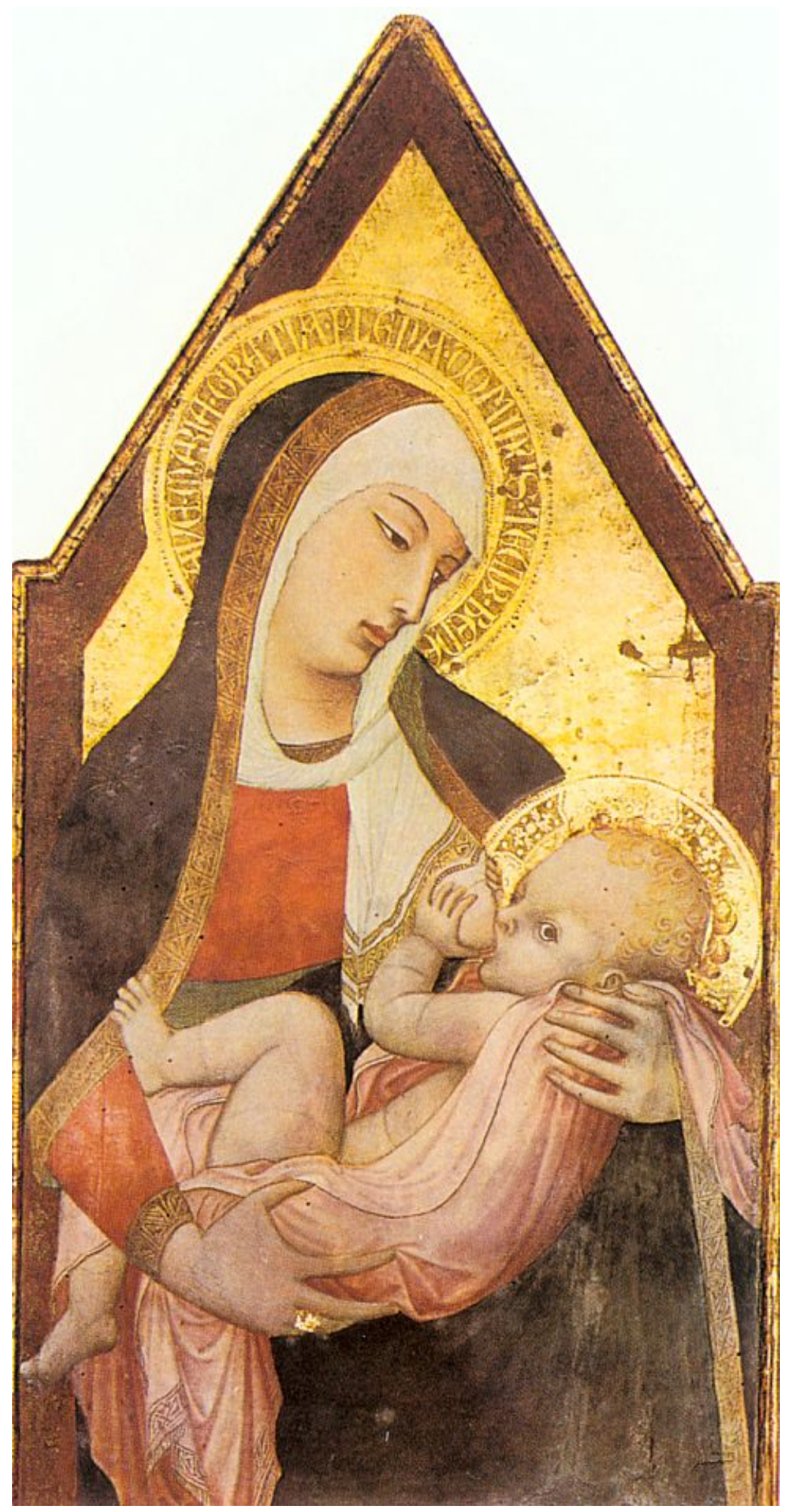

Fig. 3.7. Ambrogio Lorenzetti, Madonna del Latte, ca. 1340, tempera on panel, Palazzo Arcivescovile, Siena. 


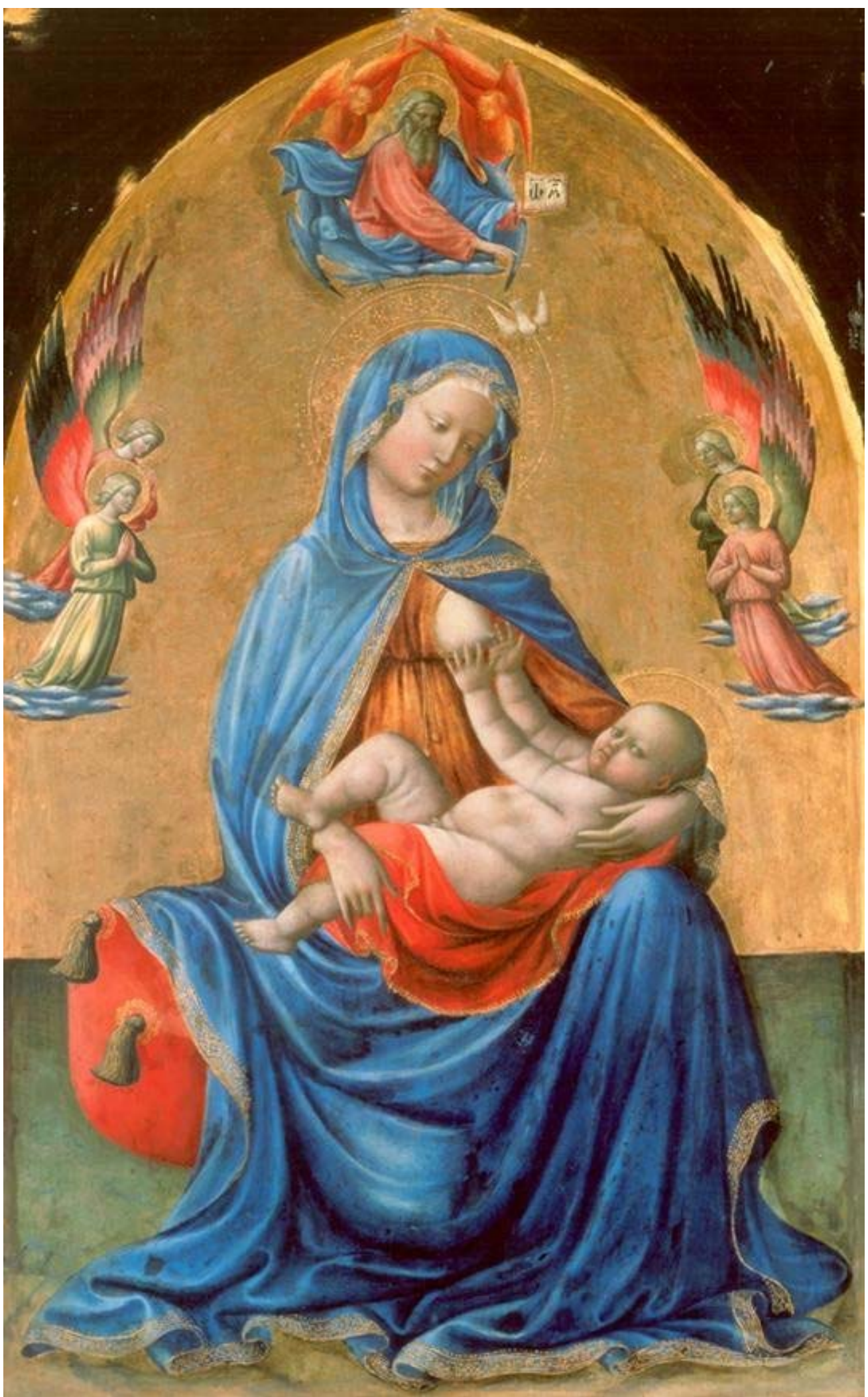

Fig. 4.1. Masolino di Panicale, Madonna and Child, 1436, Alte Pinakotek, Munich. 


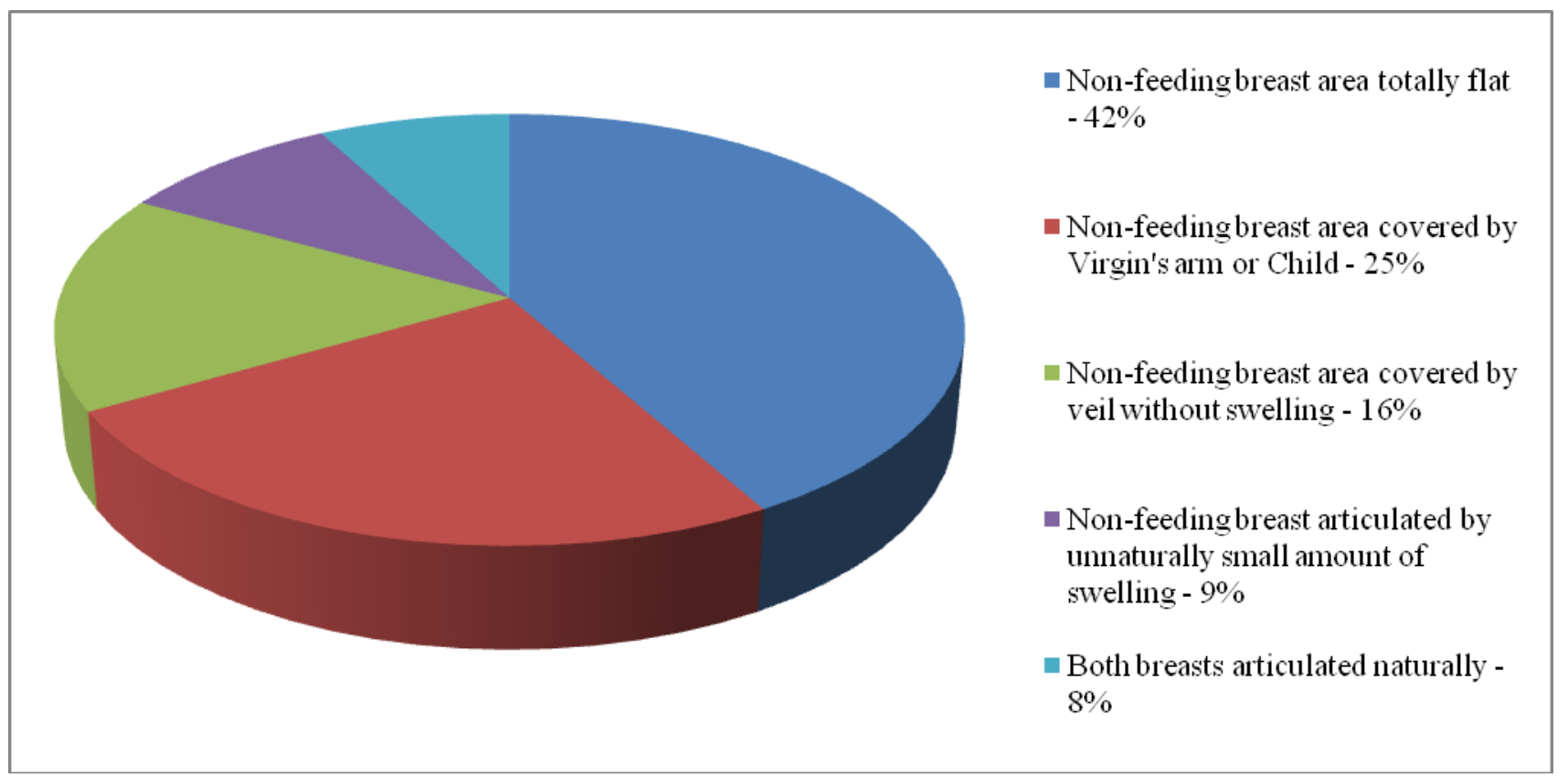

Chart 1. Diagram showing various ways and percentages breasts were depicted or dealt with in one hundred and fifty-three Italian Renaissance Madonna lactans images from the fifteenth century and the first quarter of the sixteenth certury.

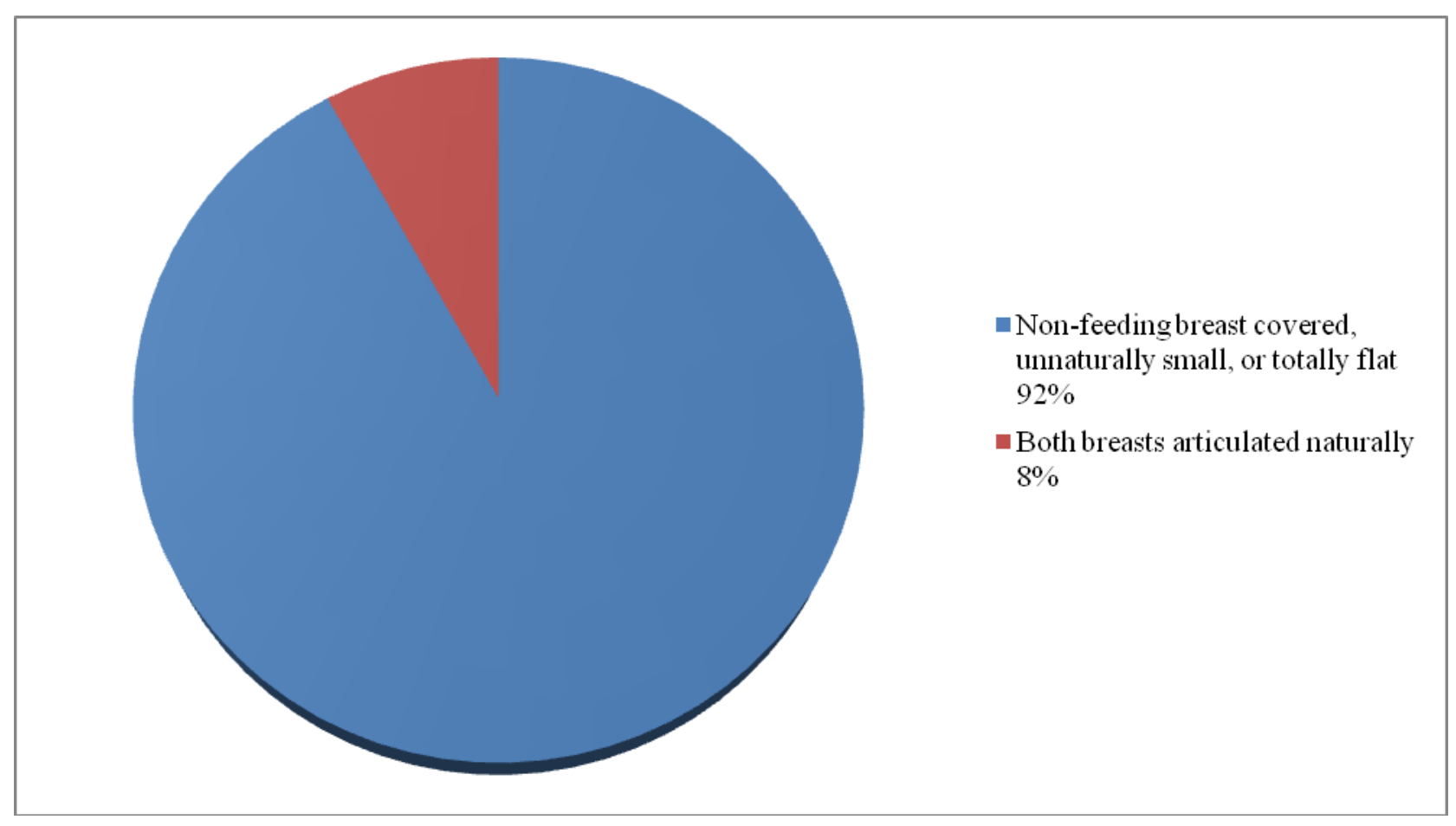

Chart 2. Diagram showing totals of the ways non-feeding breasts were dealt with vs. both breasts naturally rendered. 


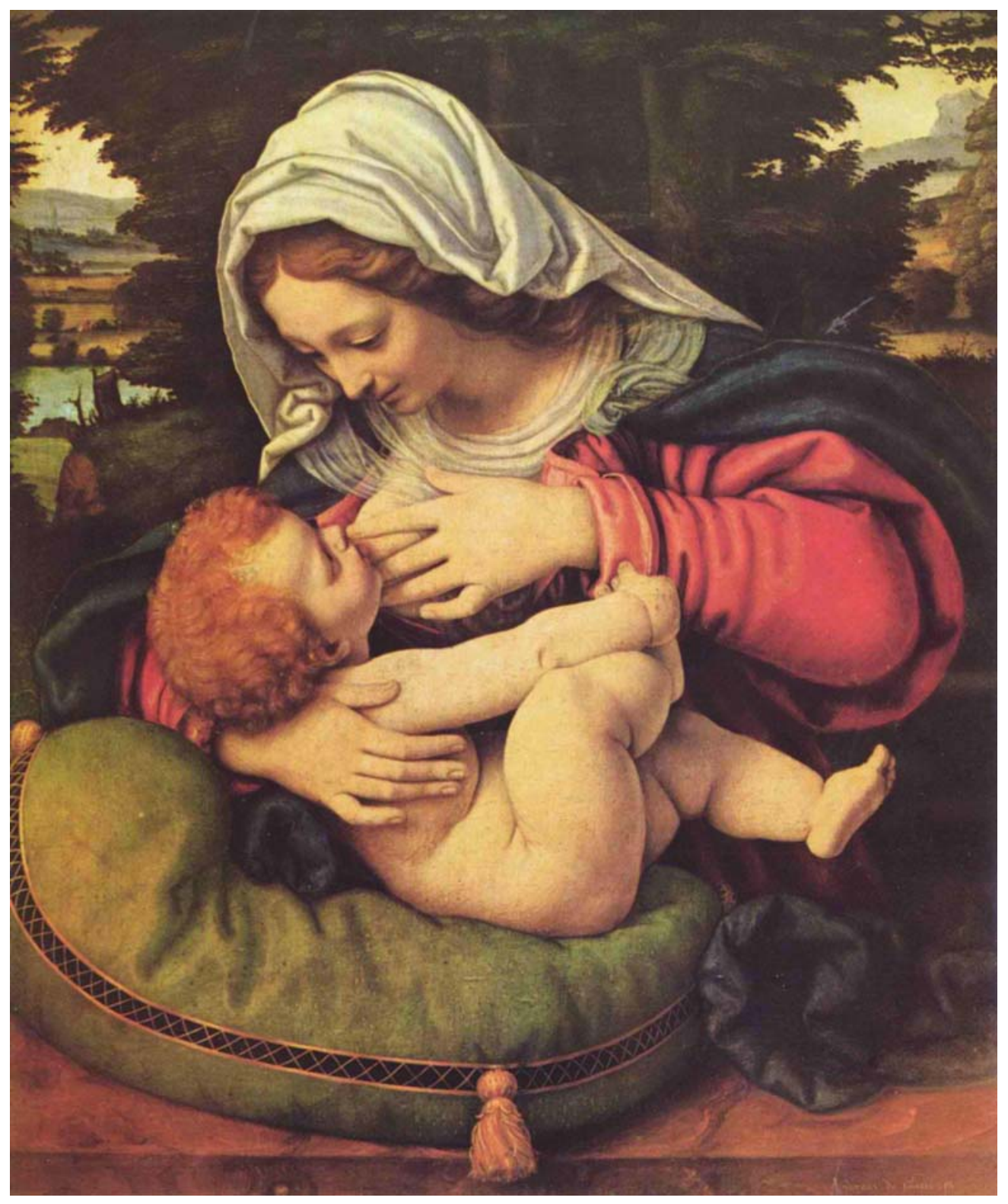

Fig. 4.2. Andrea Solario, Madonna with Green Cushion, ca. 1507, oil on wood, Paris, Musée du Louvre. 


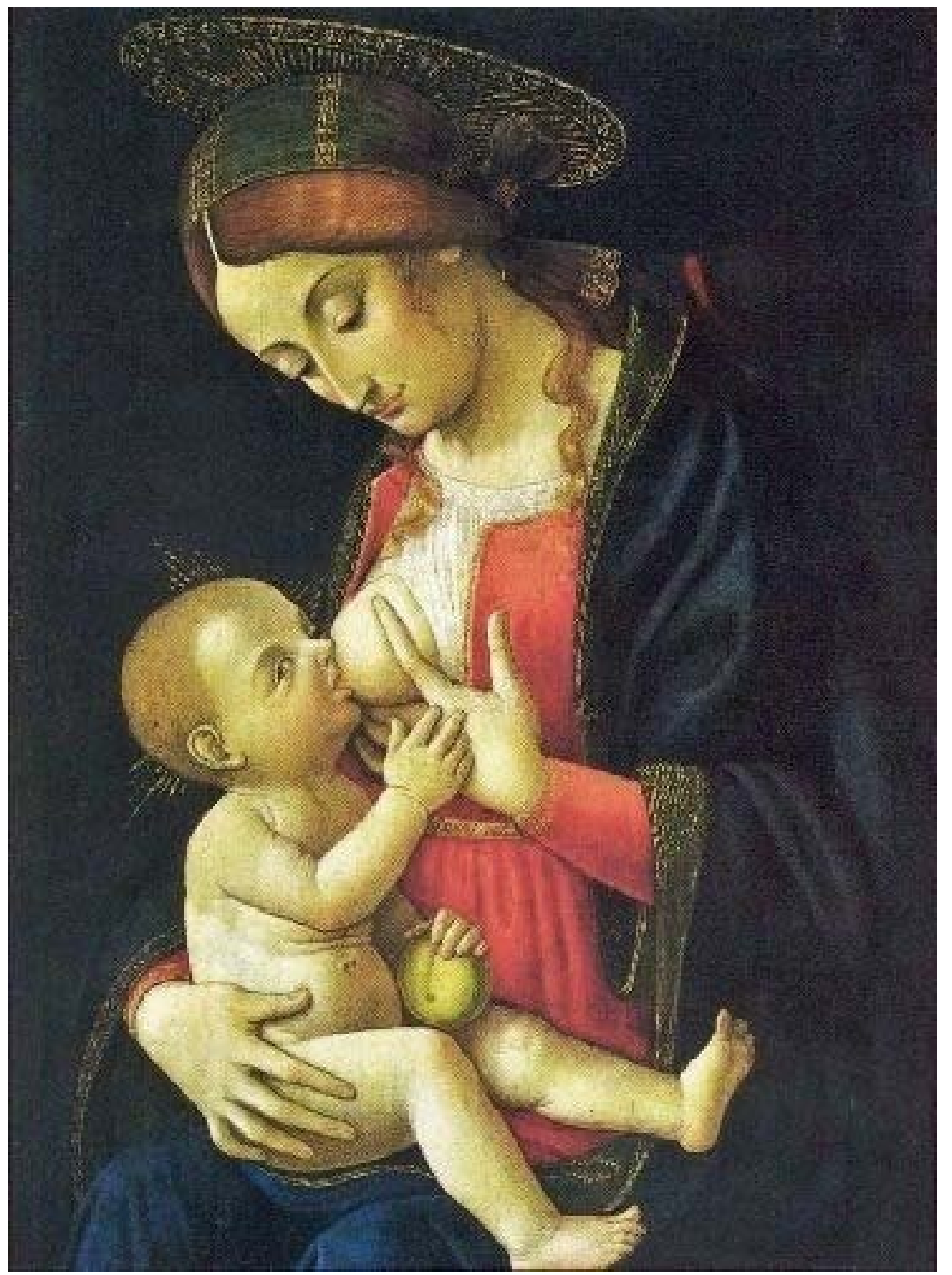

Fig. 4.3. Gian Giacomo di Alladio (detto Marcino d'Alba) Madonna del Latte, 1510, Milan, private collection. 


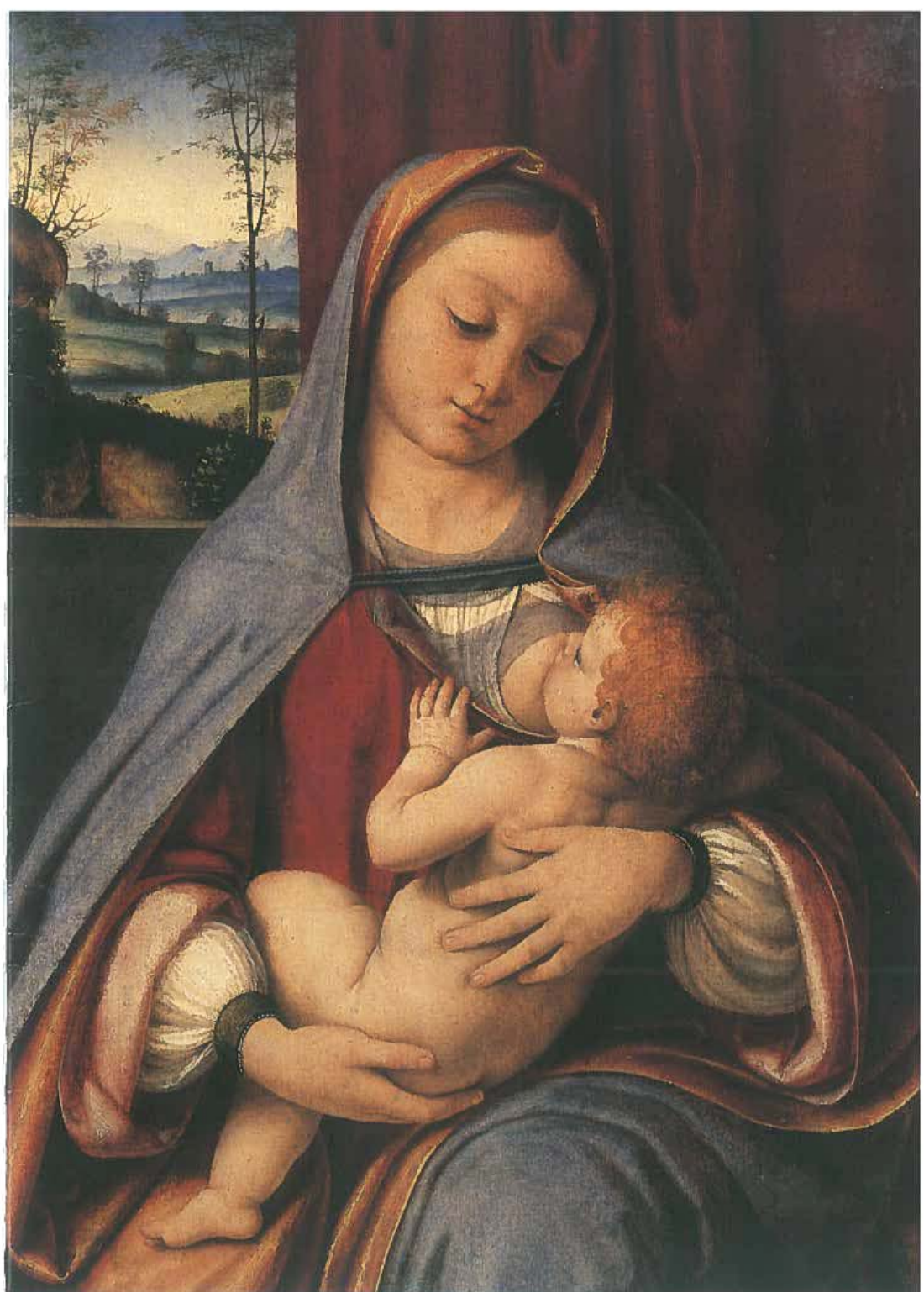

Fig.4.4. Andrea Solario, Madonna and Child, ca. 1500, Columbia Museum of Art, Columbia, SC. 


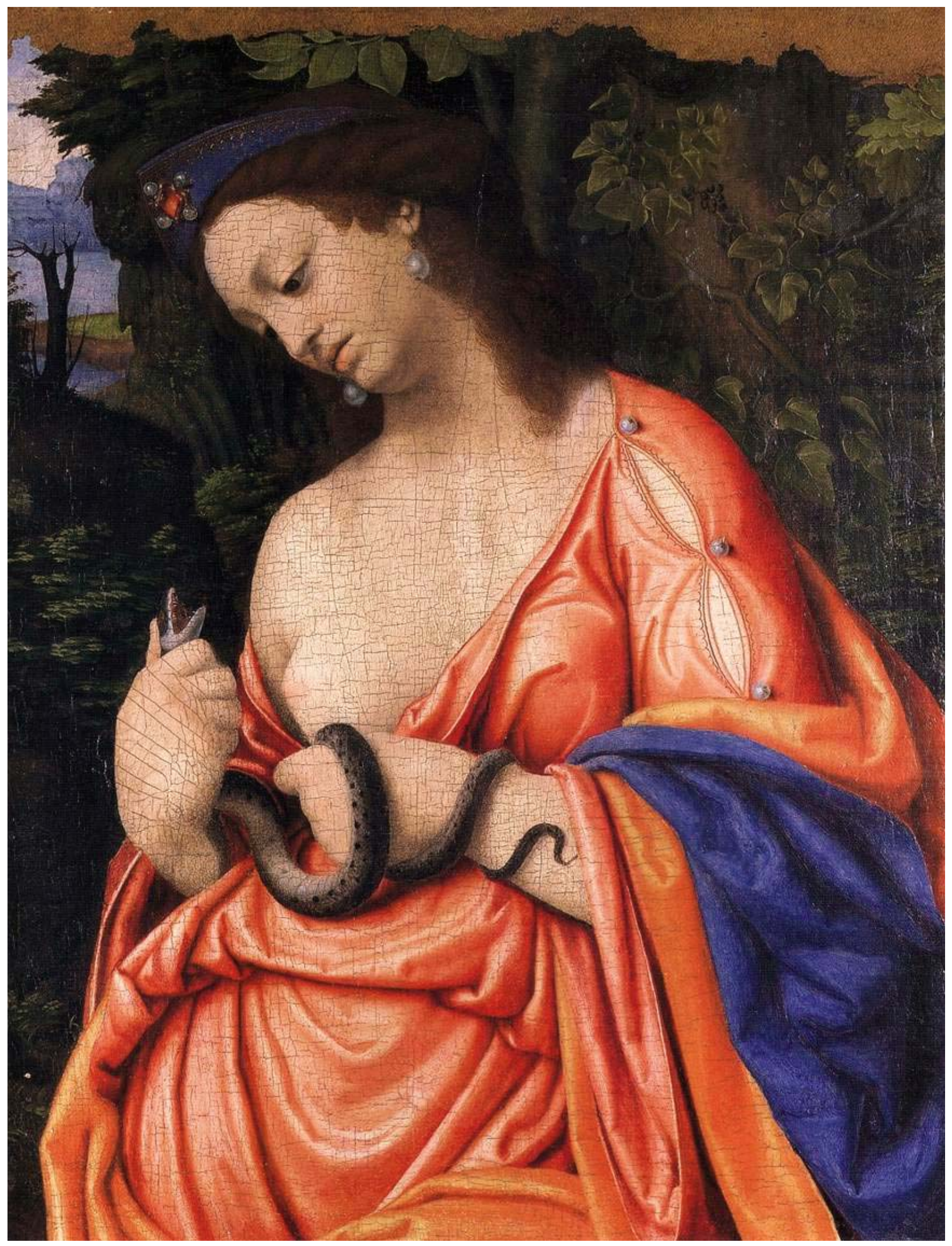

Fig. 4.5. Andrea Solario, Cleopatra, early sixteenth century, private collection. 


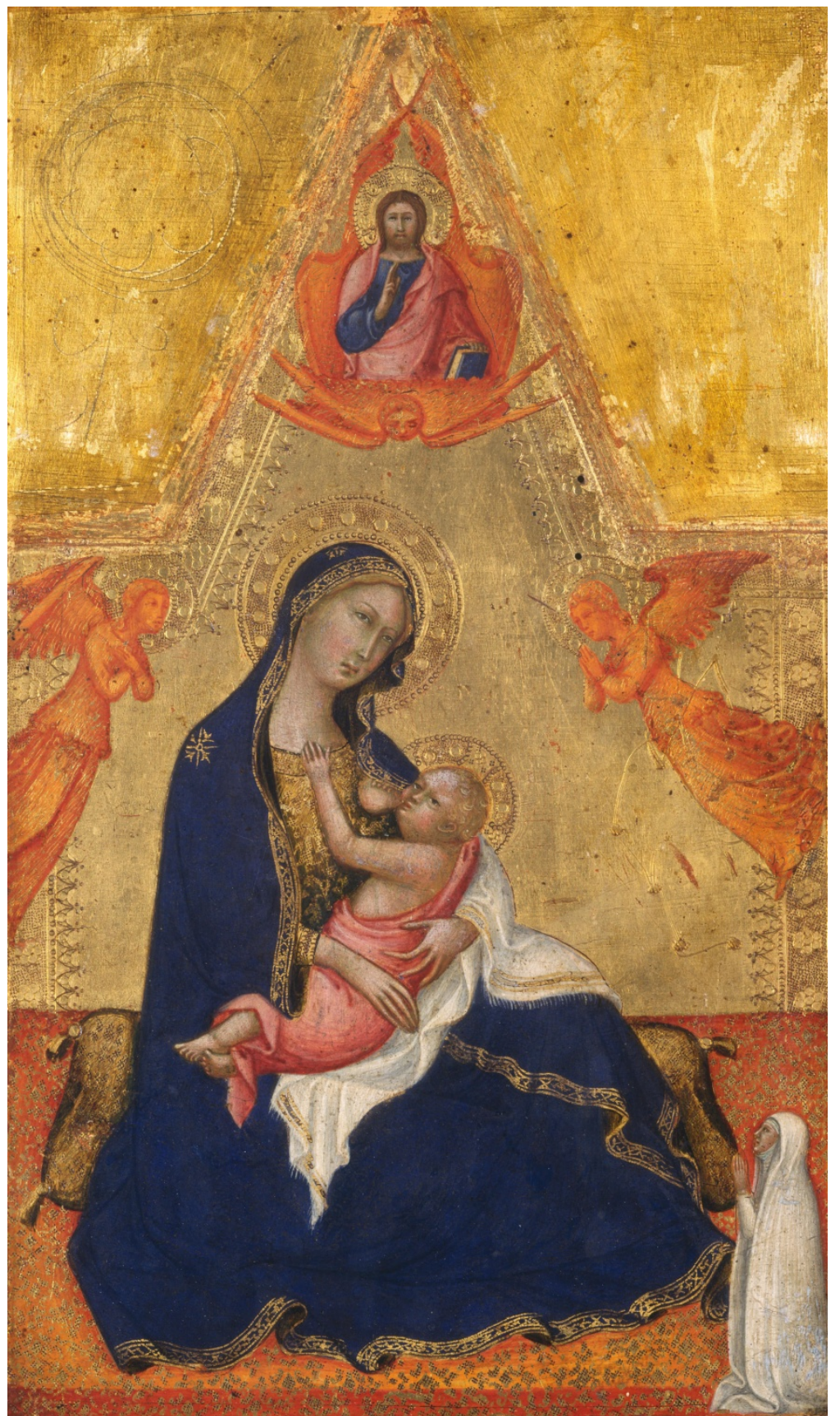

Fig. 4.6. Andrea di Bartolo, Madonna of Humility, ca. 1394-1415, National Gallery of Art, Washington DC. 


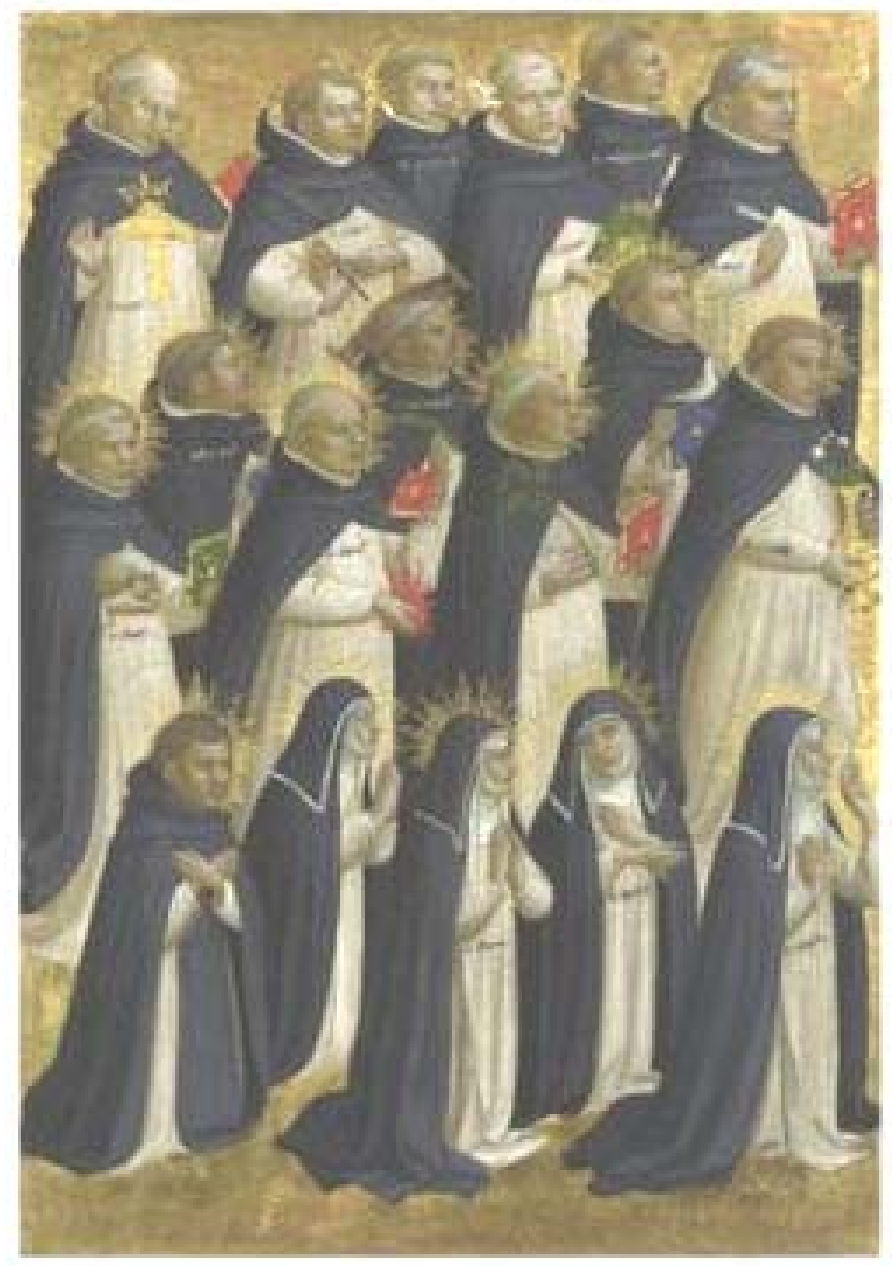

Fig. 4.7. Fra Angelico, Eighteen Dominican Beati, 1425, detail of predella from the altarpiece at San Domenico, Fiesole. 


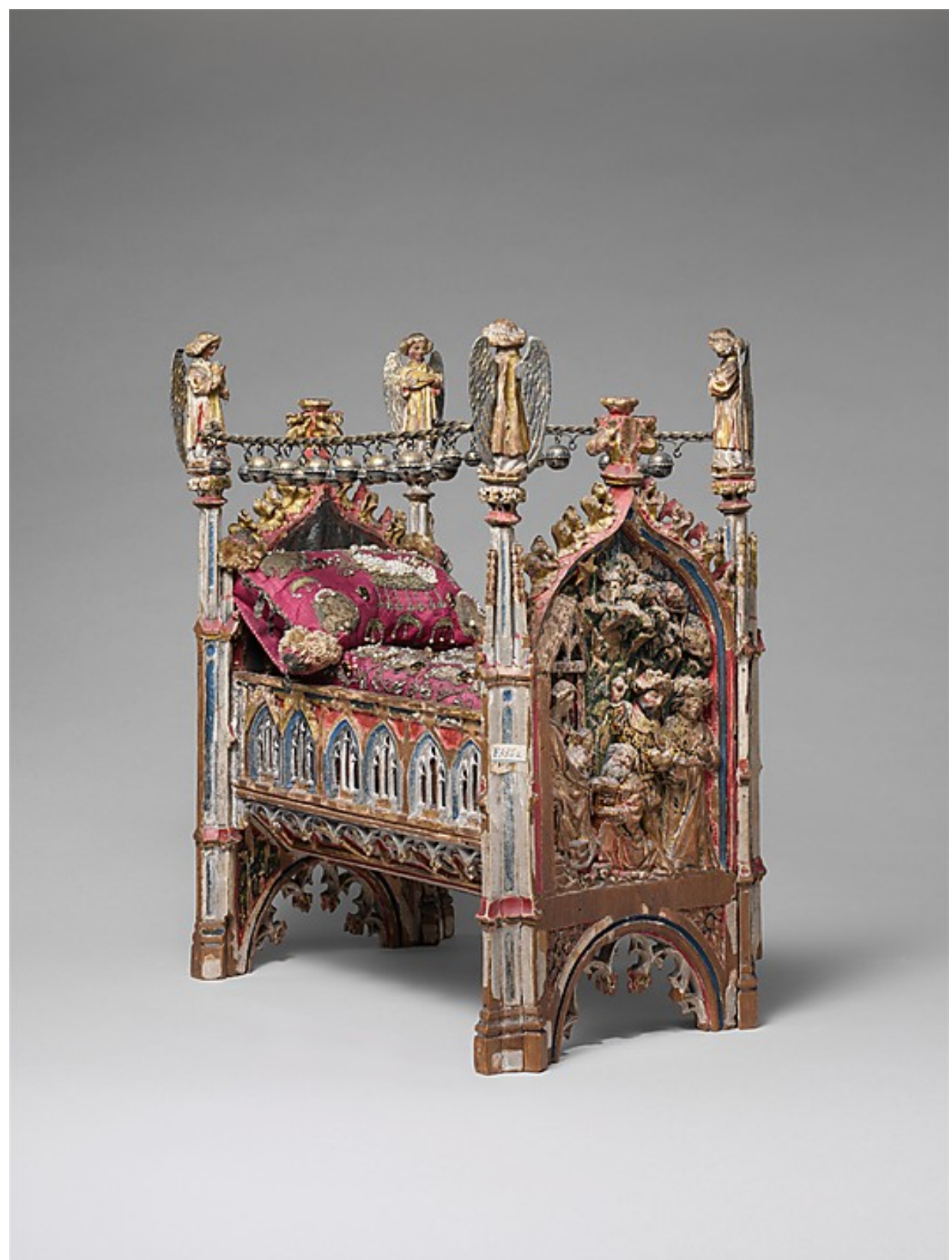

Fig. 4.8. Liturgical cradle from the Grand Beguinage in Louvaine, fifteenth century. 


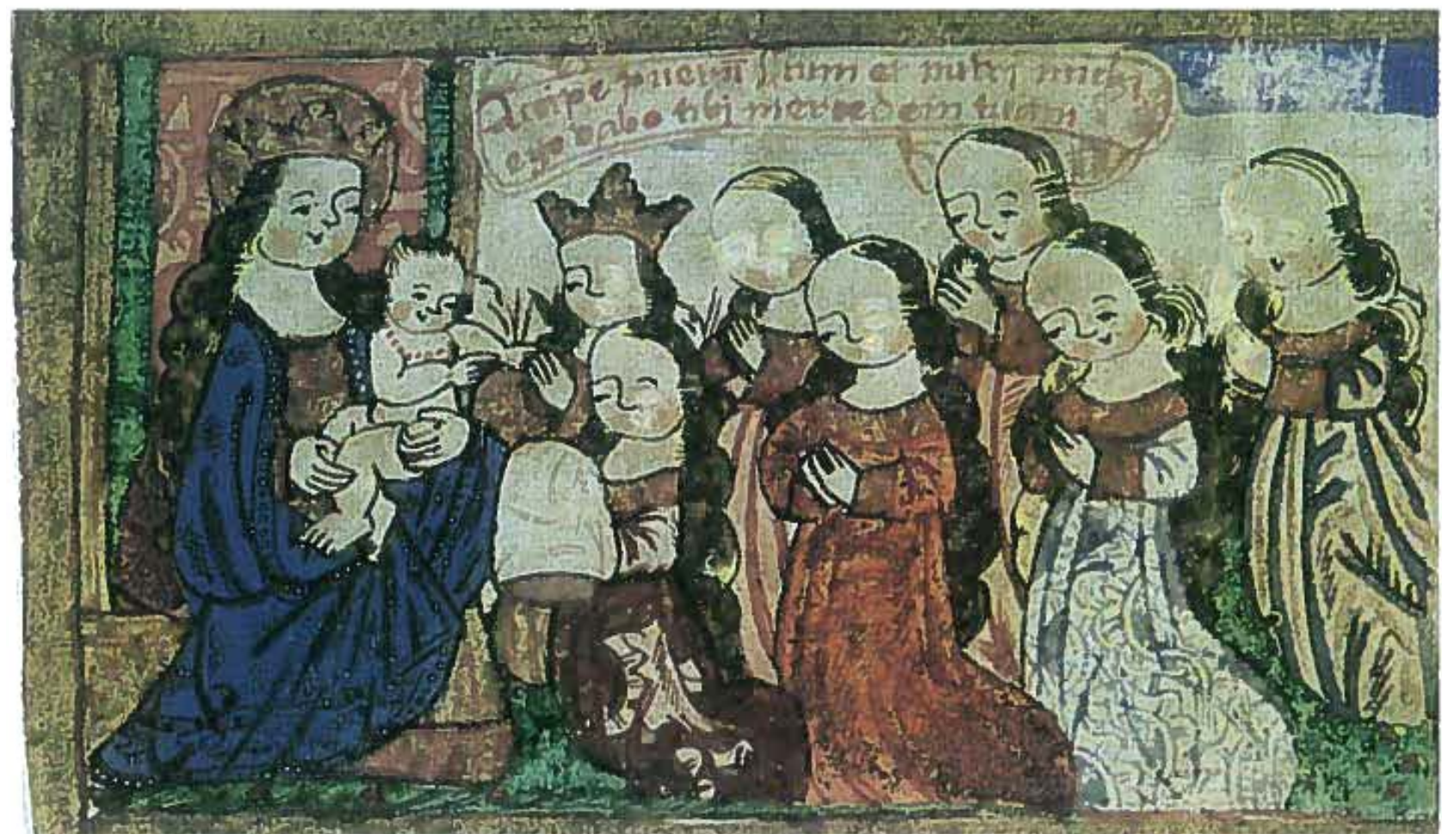

Fig. 4.9. Anonymous, Consecration of Virgins, ca.1500, Eichstätt, St. Walburg. 


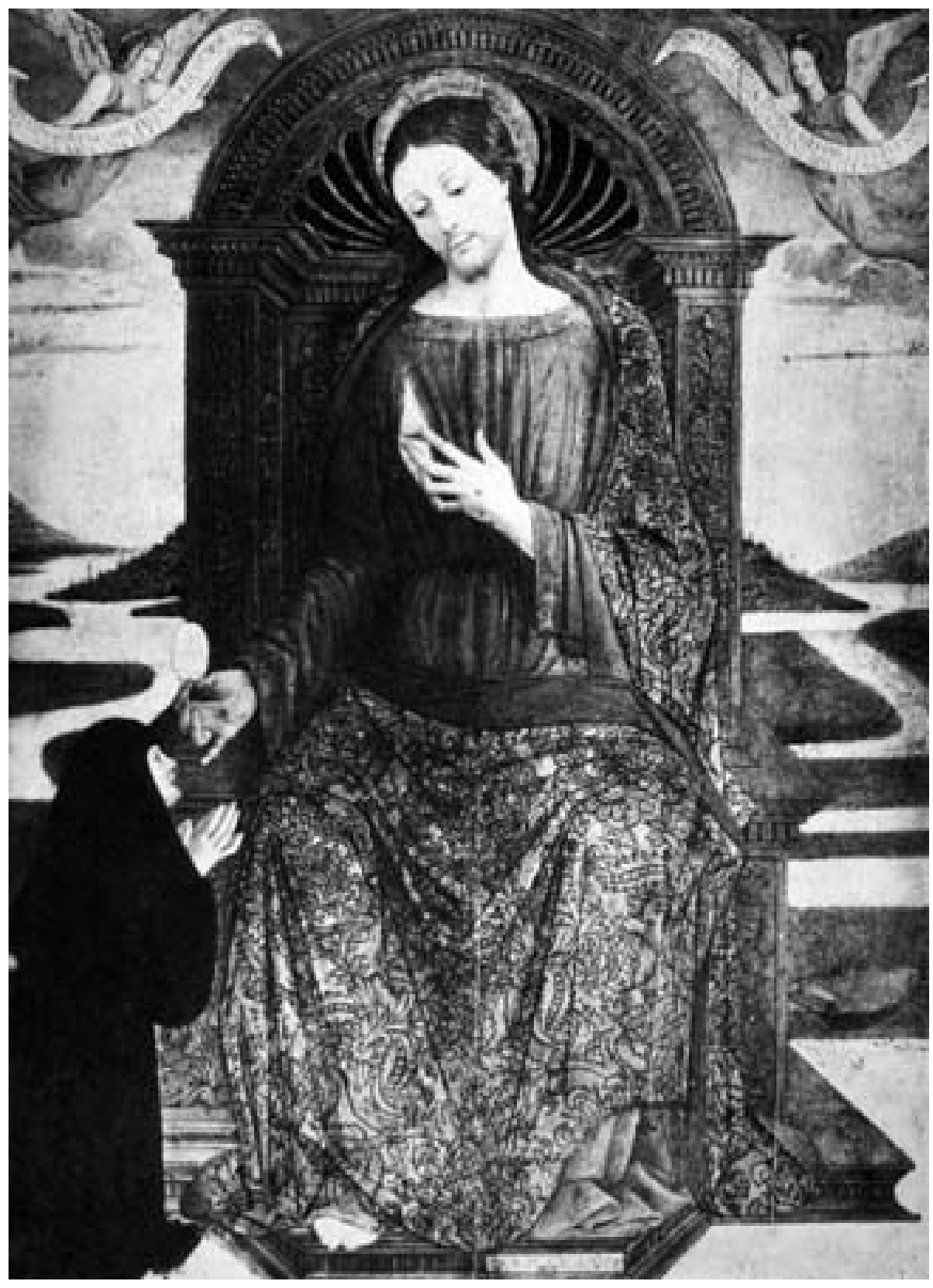

Fig. 4.10. Quirizio da Murano, The Savior, 1460 - 1478, tempera and oil on panel, Accademia, Venice. 


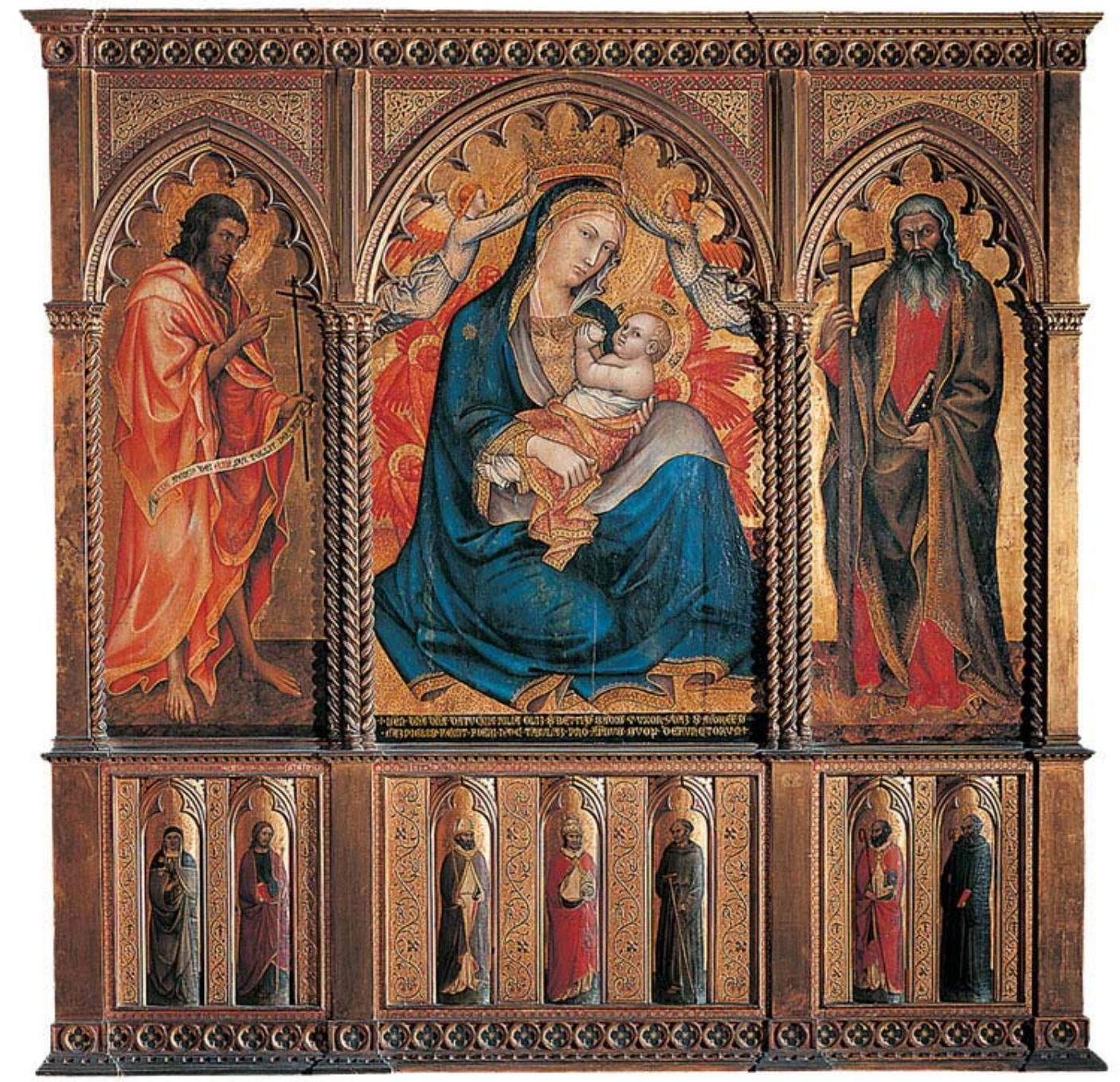

Fig. 4.11. Taddeo di Bartolo, Virgin and Child with Saint John the Baptist and Saint Andrew, 1395, tempera on panel, Museum of Fine Arts Budapest. 


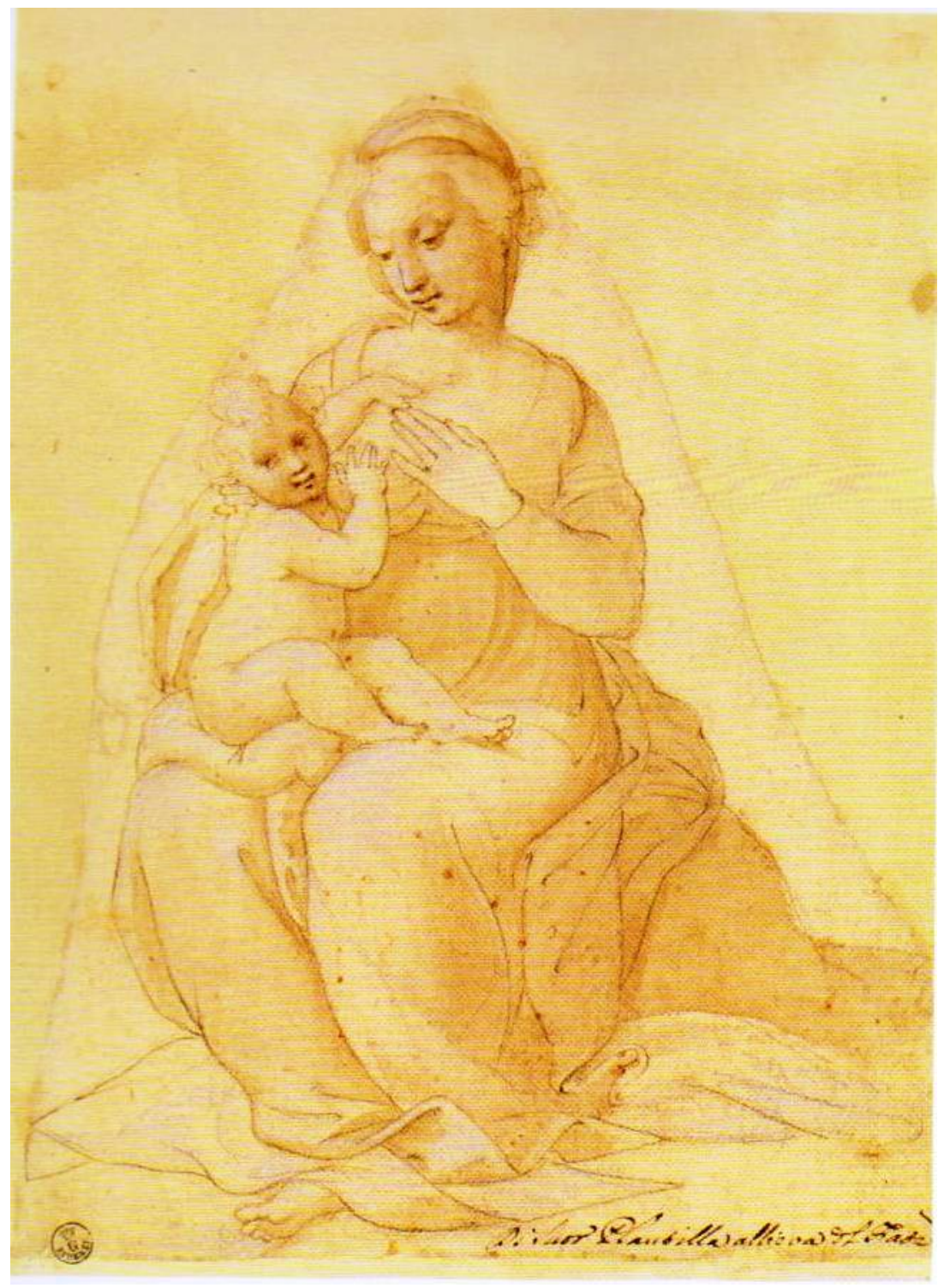

Fig. 4.12. Plautilla Nelli, Seated Madonna Nursing, sixteenth century, GDSU, Uffizi, Florence, $249 \mathrm{~S}$. 


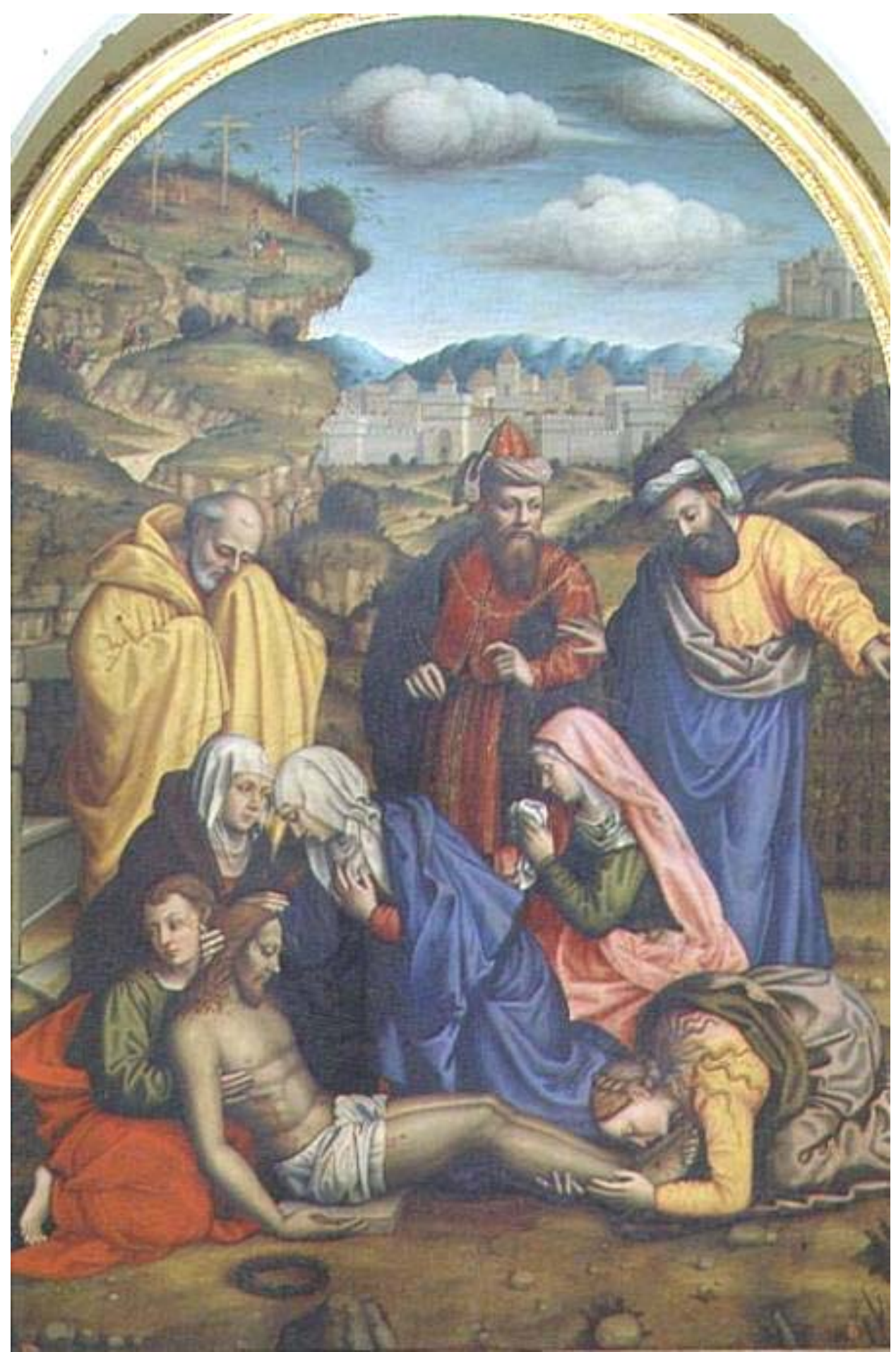

Fig. 4. 13. Plautilla Nelli, Lamentation, sixteenth century, Museo di San Marco, Florence. 


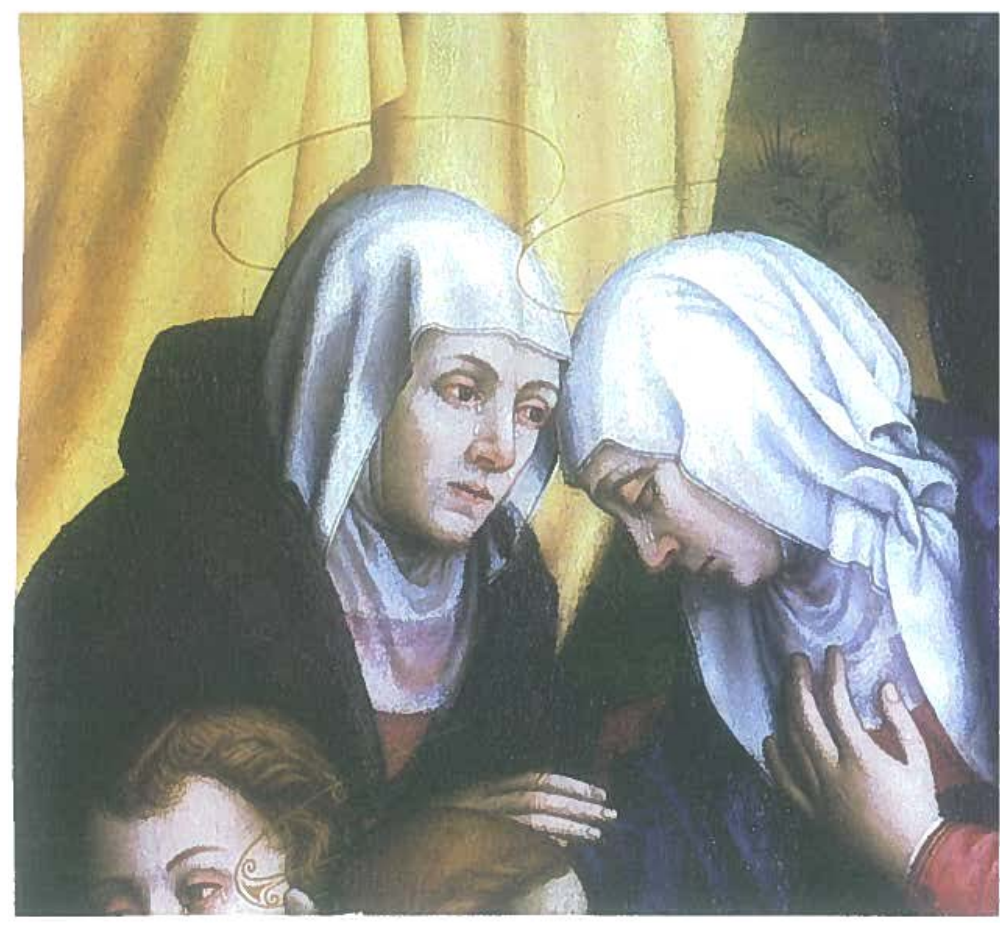

Fig. 4.14. Plautilla Nelli, Lamentation, detail, Museo di San Marco, Florence. 


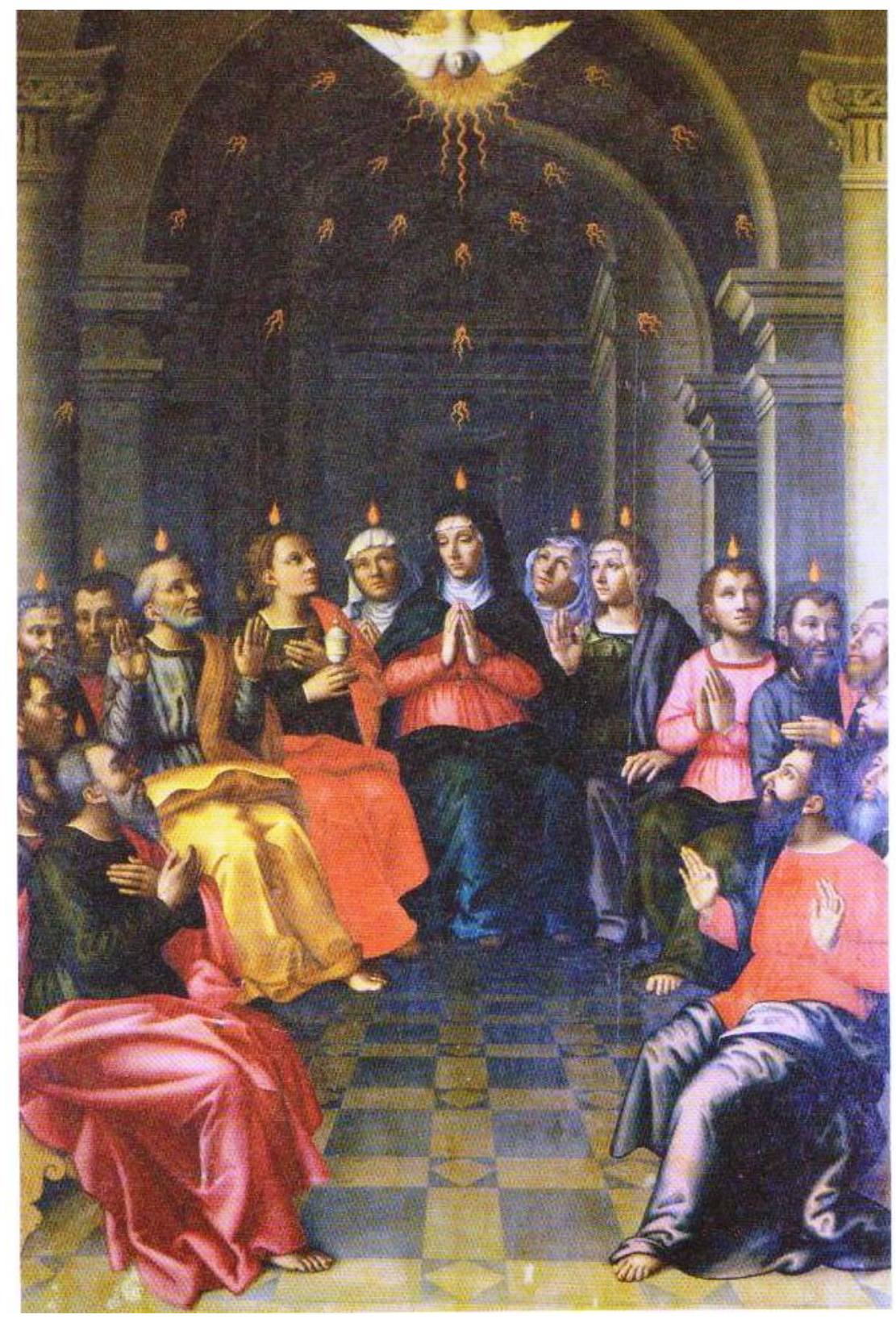

Fig. 4.15. Plautilla Nelli, Pentecost,San Domenico, Perugia. 


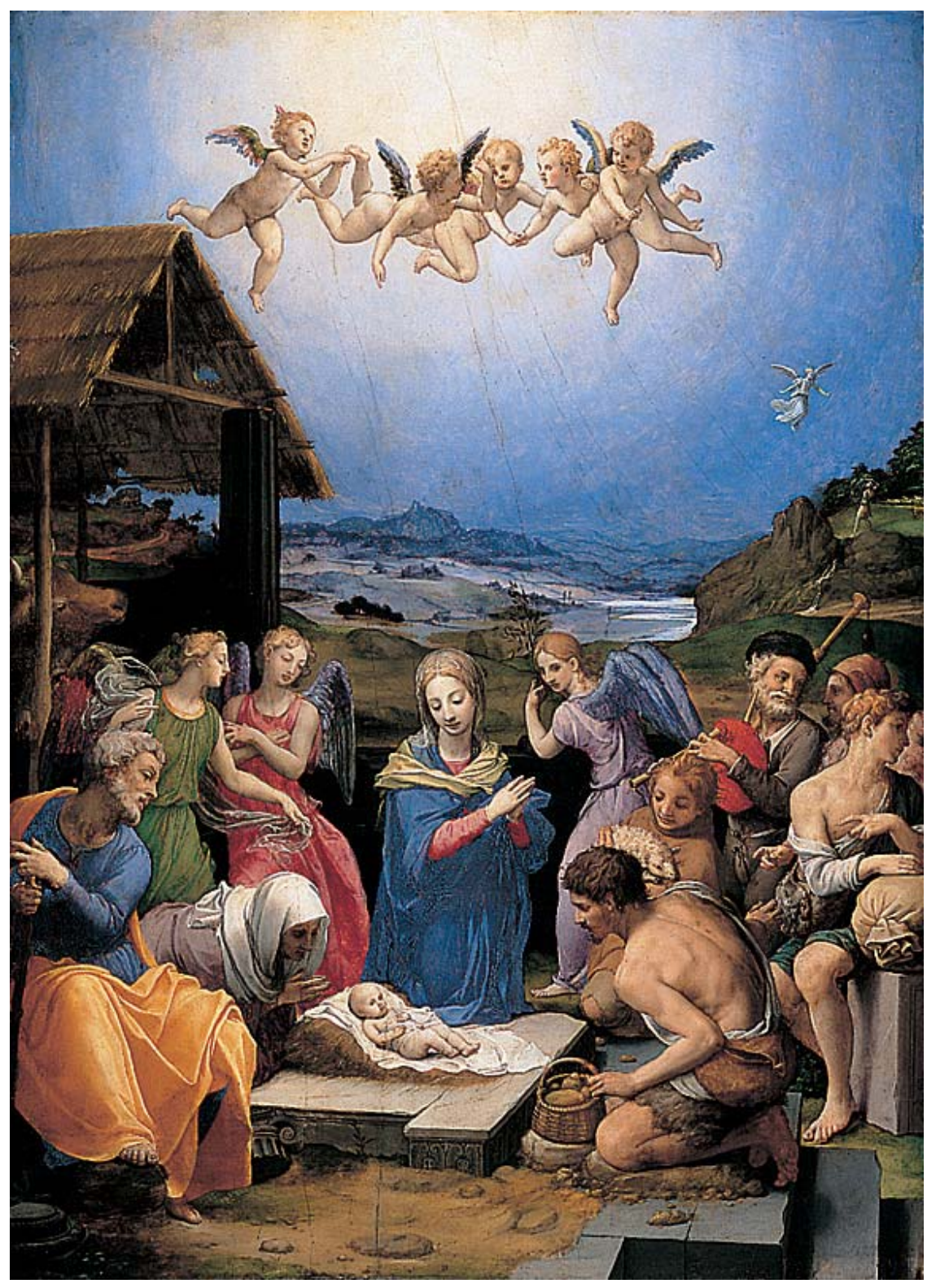

Fig. 4.16. Agnolo Bronzino, Adoration of the Shepherds, ca. 1538, oil on panel, Szépmüvészeti Múzeum, Budapest. 


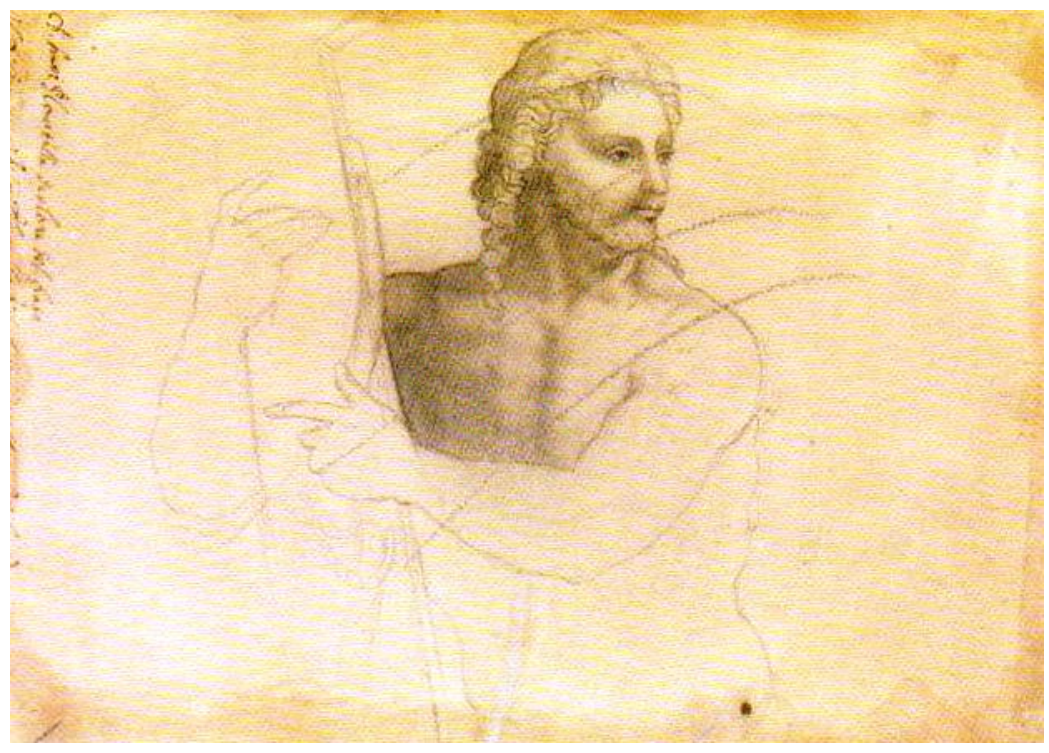

Fig. 4.17. Plautilla Nelli, Partial Study of Michelangelo's Risen Christ, GDSU, Florence, 6762F v. 


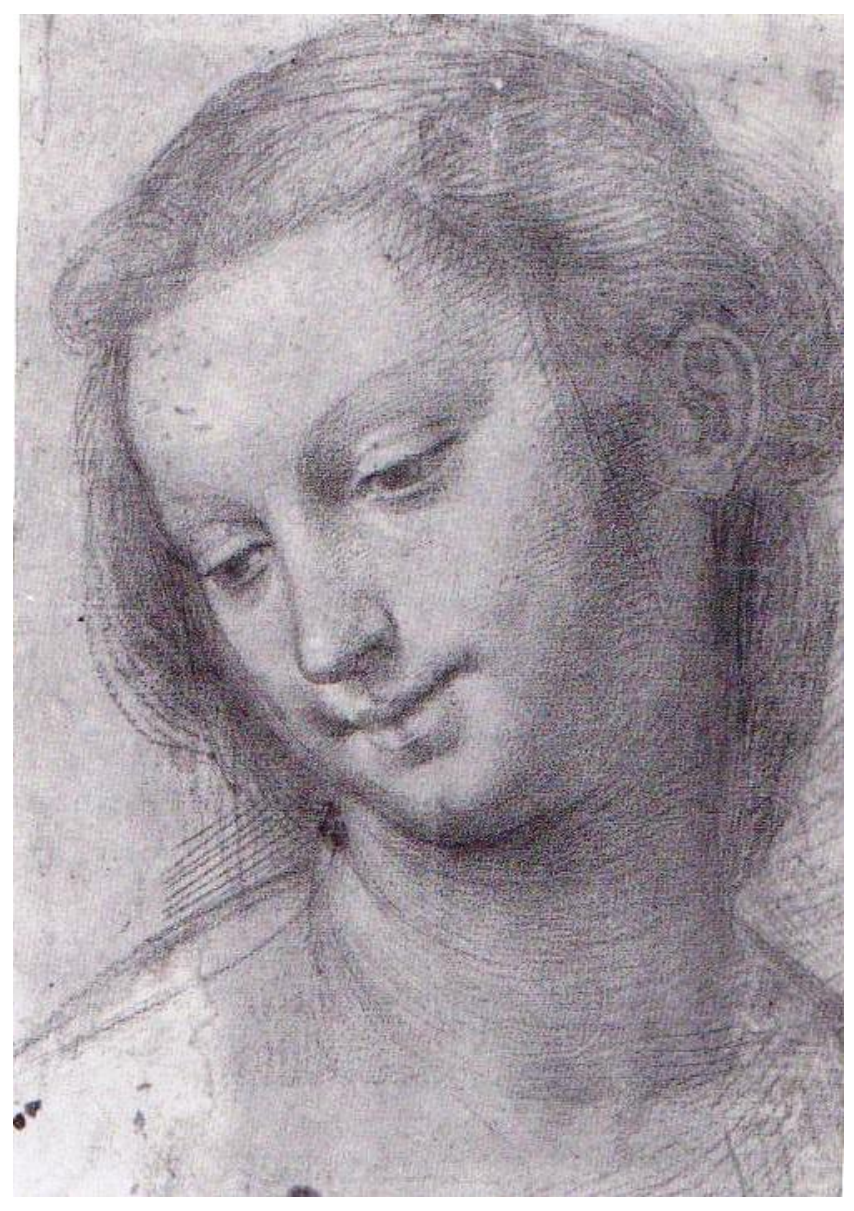

Fig. 4.18. Fra Bartolommeo Study for the Head of the Virgin, black chalk heightened with yellow, Museum Boymans-van Beuningen, Rotterdam.

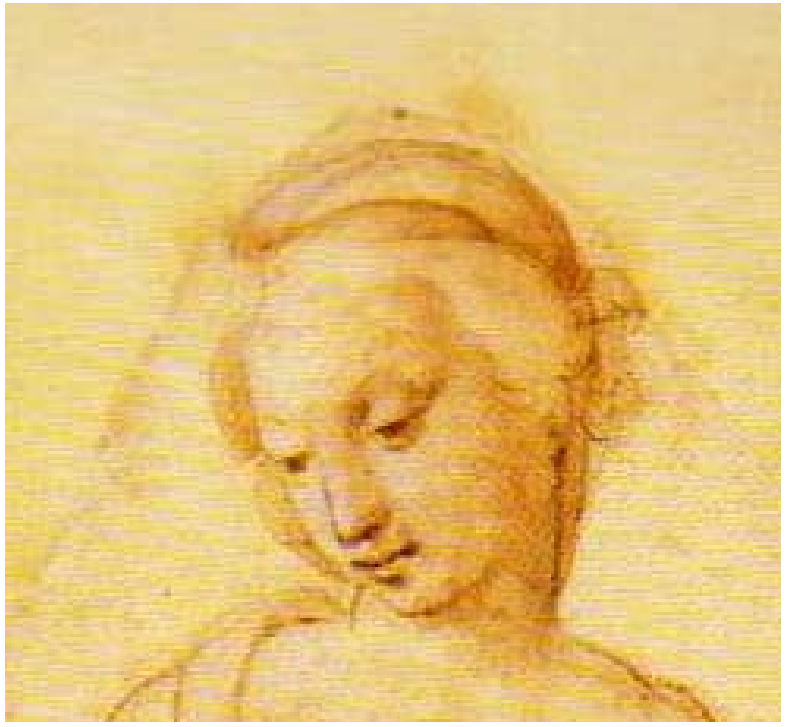

Fig. 4.19. Plautilla Nelli, Seated Madonna Nursing, detail, GDSU, Uffizi, Florence, 249 S. 


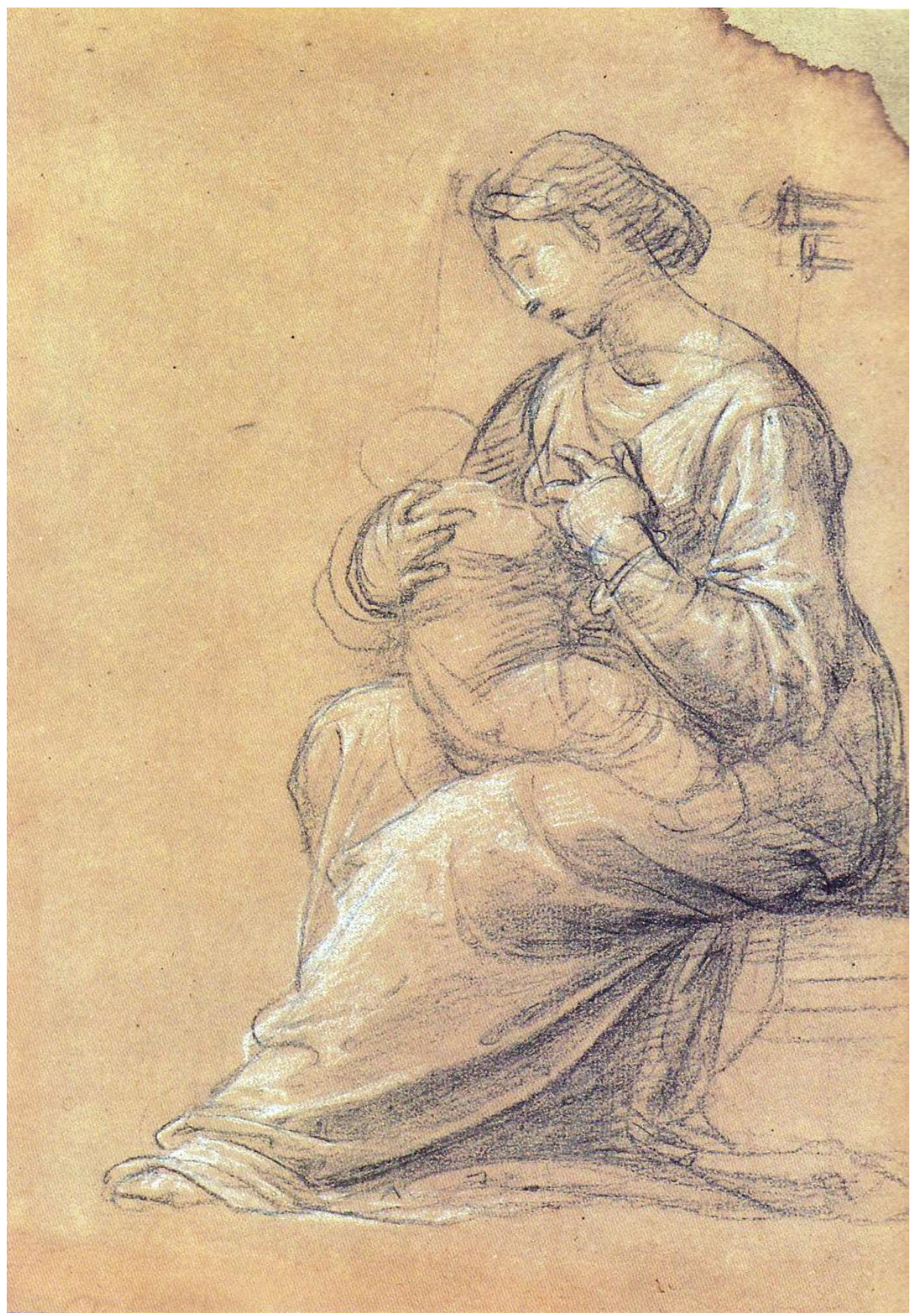

Fig. 4.20. Bartolommeo Study for a Woman Nursing a Baby (recto), Rotterdam. 


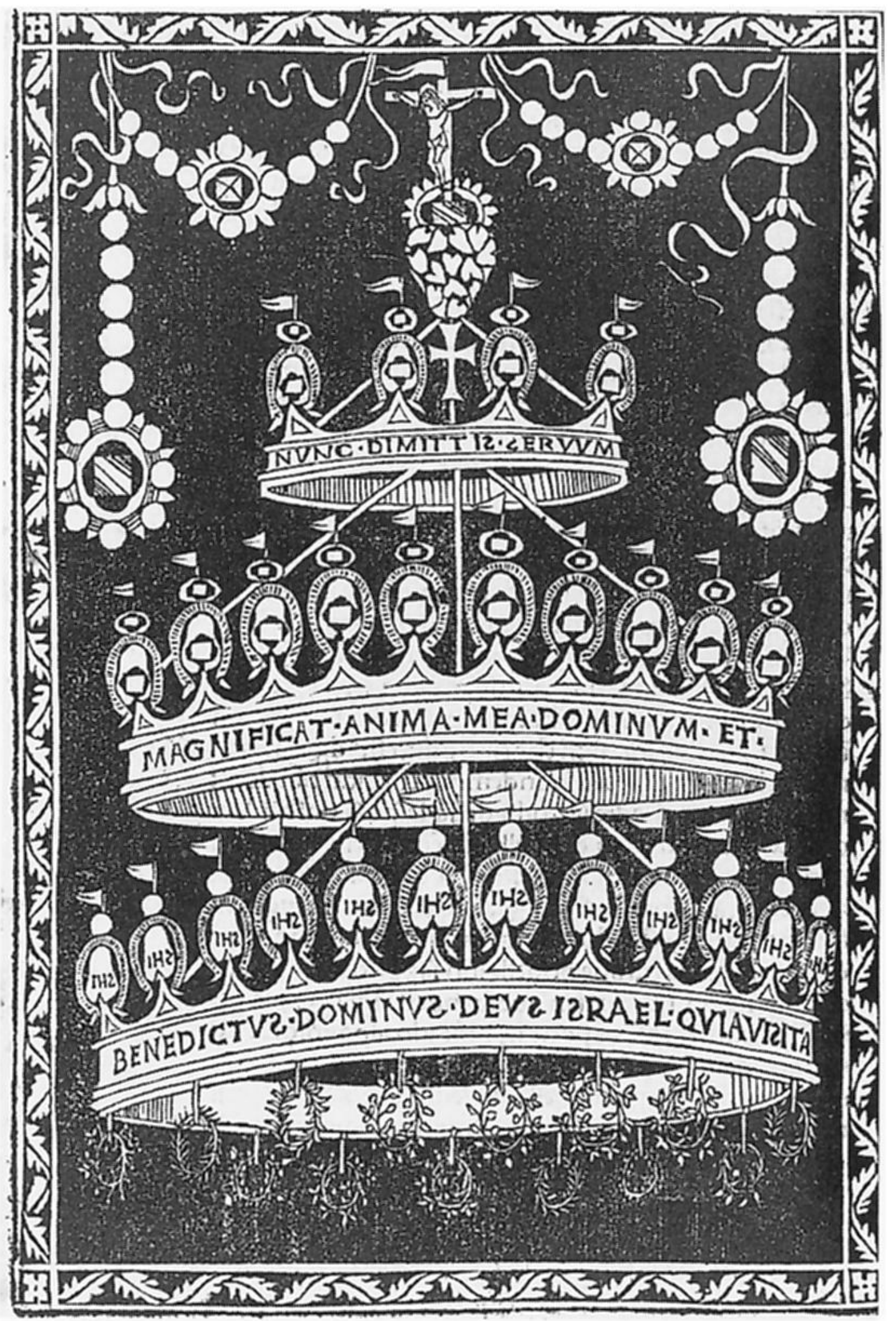

Fig. 4.21. Girolamo Savonarola, Compendio di revelatione, 1496, fol. 29v. Florence. 


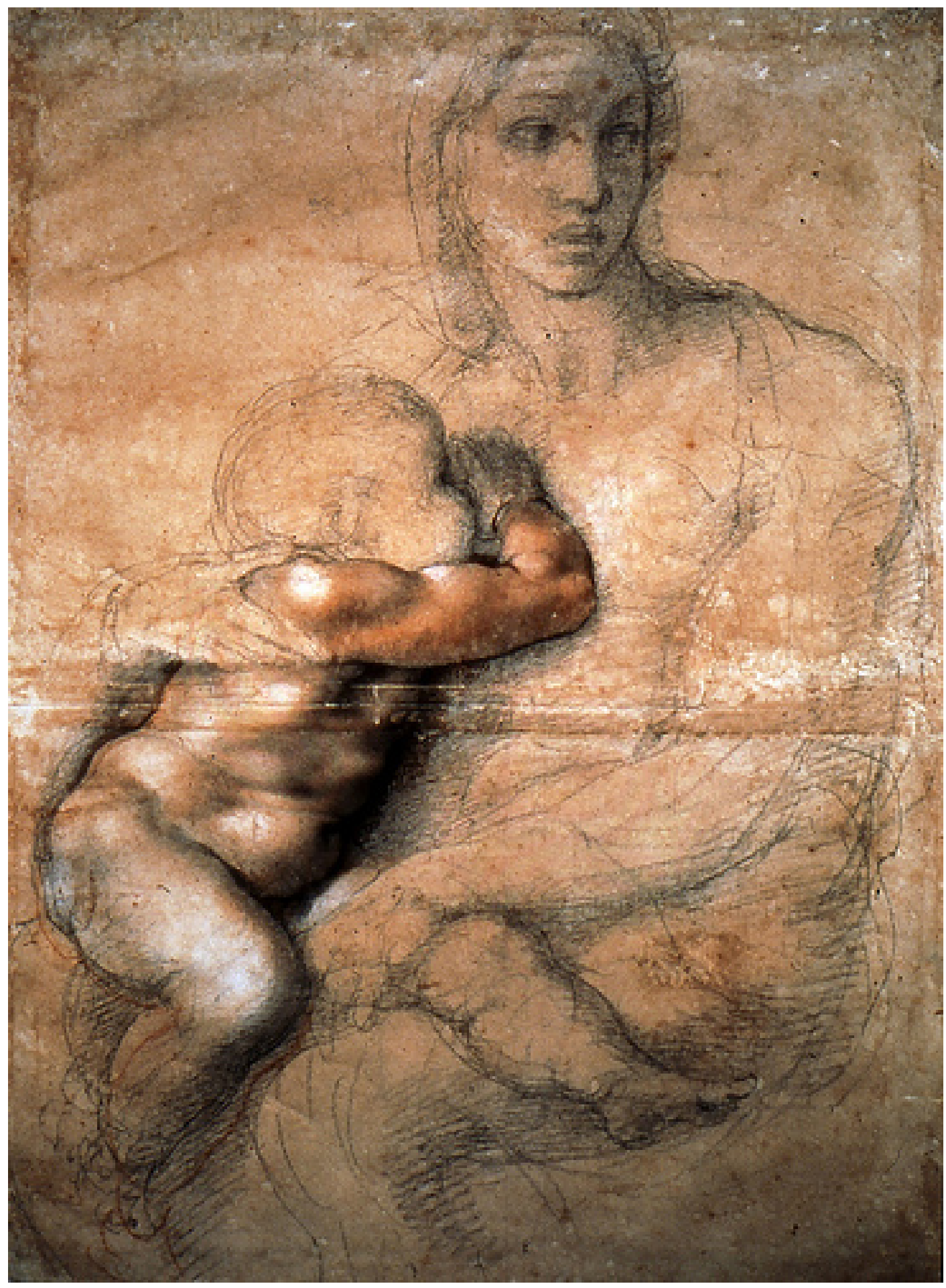

Fig. 4.22. Michelangelo, Madonna and Child, ca.1525 - 30, red and black chalk, white lead, and ink on paper. Casa Buonarroti, Florence. 


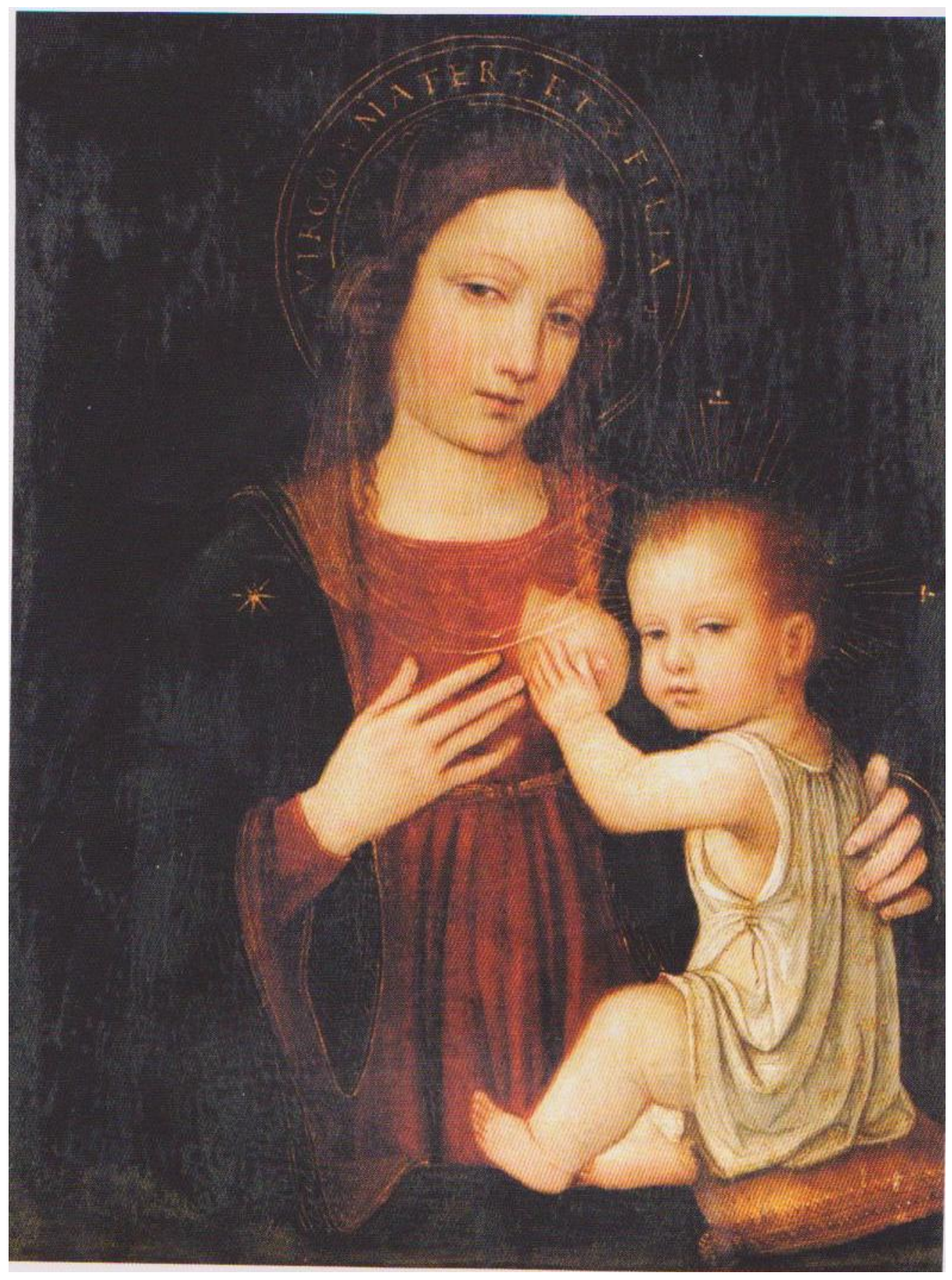

Fig. 4.23. Ambrogio da Fossano, Madonna del Latte, (active in Milan 1481 - 1523), private collection. 


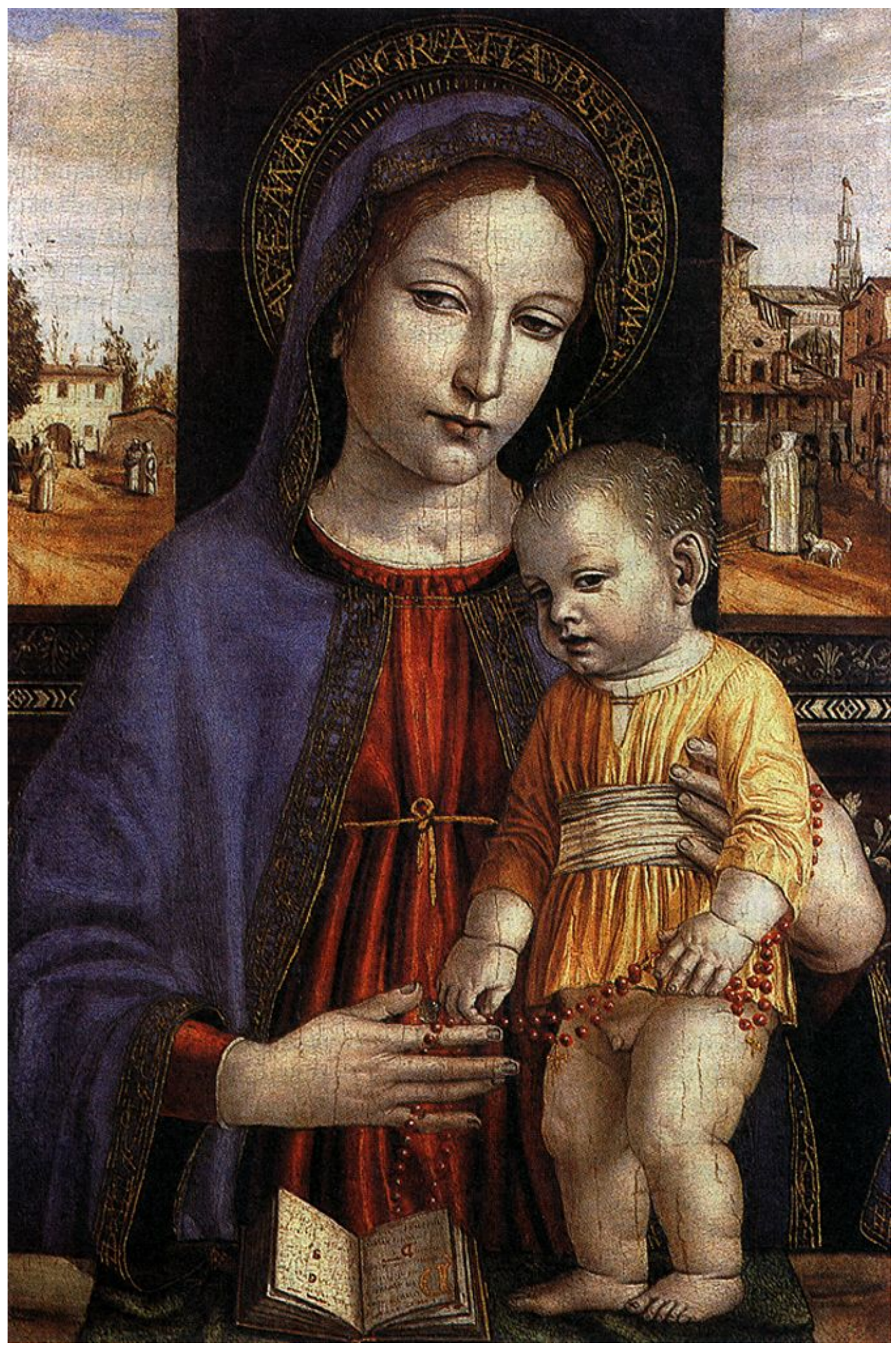

Fig. 4.24. Ambrogio da Fossano, The Virgin and Child, ca.1488 - 90, oil on poplar, National Gallery of Art, London. 


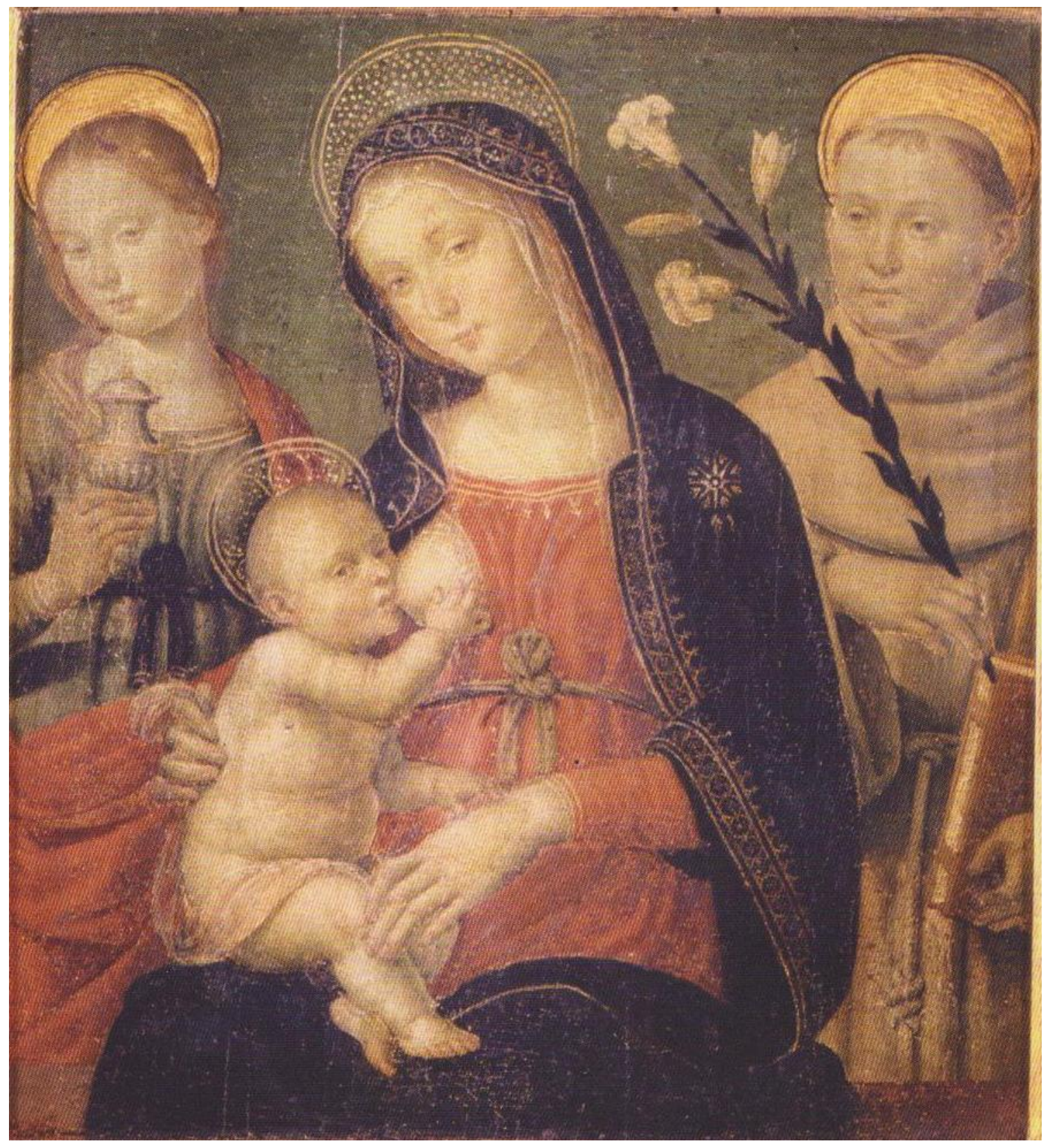

Fig. 4.25. Giovanni di Pietro (called Lo Spagna), Madonna del Latte between Saint Mary Magdalene and Saint Anthony of Padua, first quarter of the sixteenth century, Vatican Museum, Rome. 


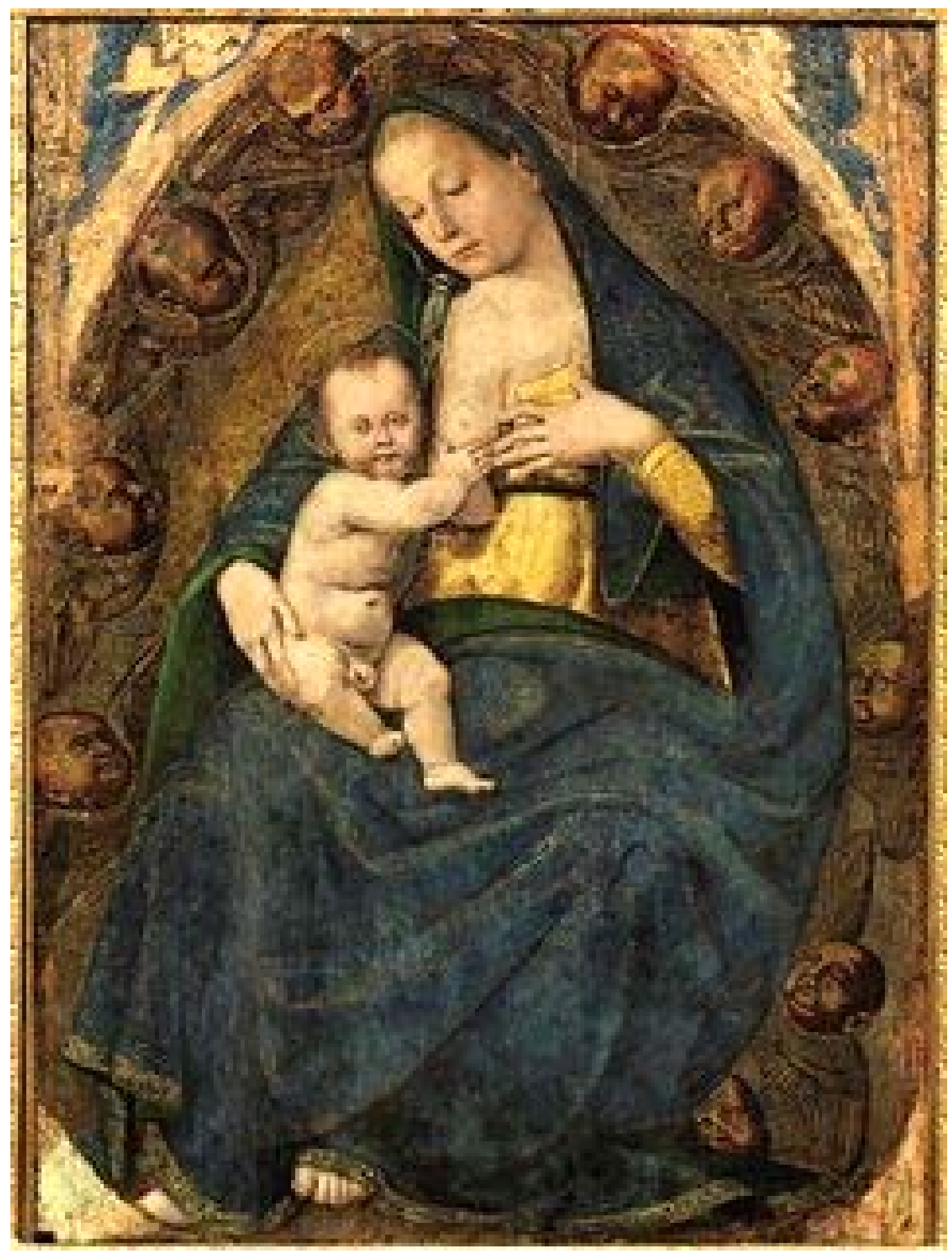

Fig. 4.26. Luca Signorelli, Madonna in Glory with Angels, 1480s, oil on wood, Pinacoteca di Brera, Milan. 


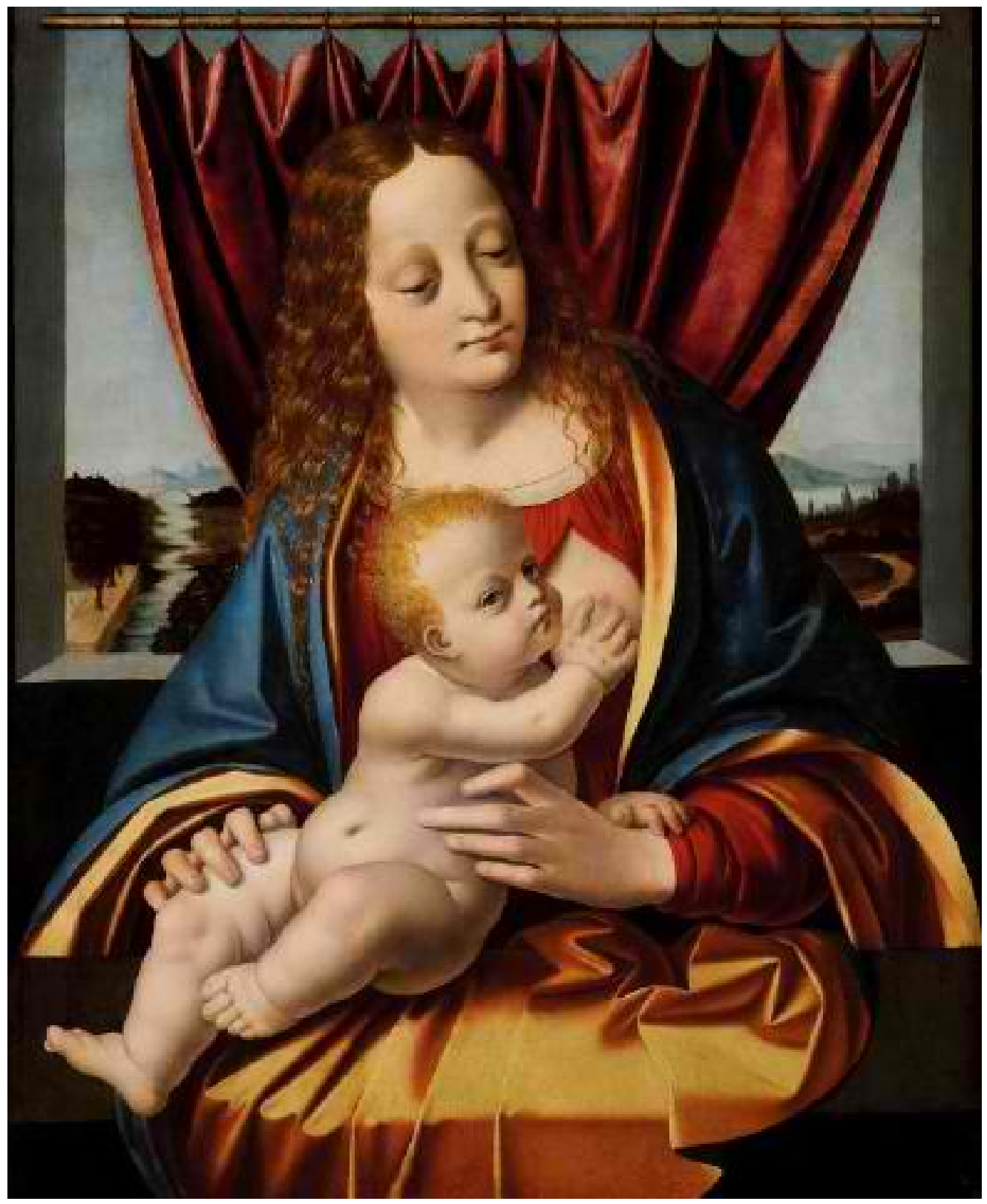

Fig. 4.27. Marco d'Oggiono, Madonna del Latte, late fifteenth or early sixteenth century, tempera on panel, Auckland Art Gallery, New Zealand. 


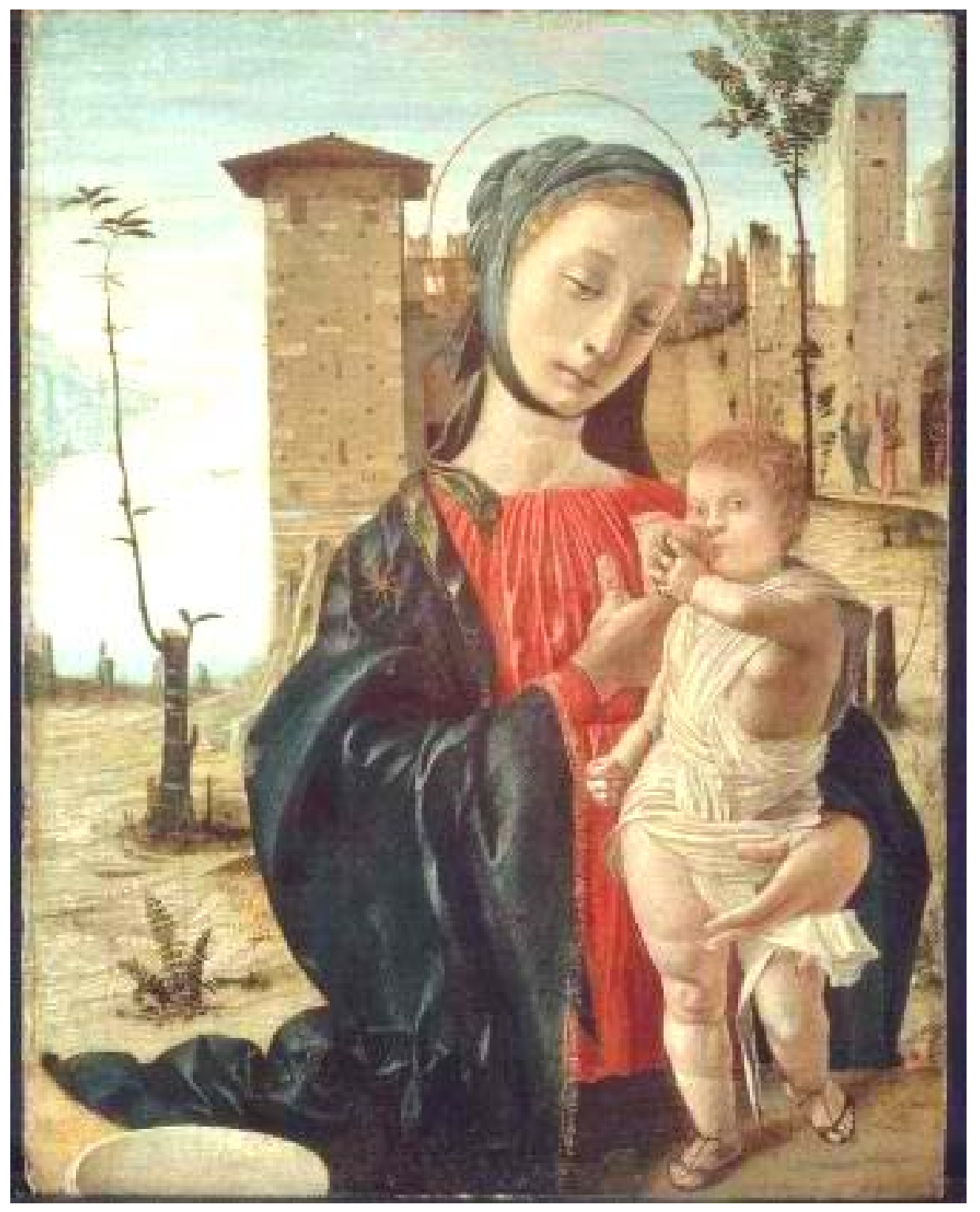

Fig. 4.28. Bartolomeo Suardi called Bramantino, Virgin and Child, 1485 - 90, tempera and oil on panel, Museum of Fine Arts, Boston. 


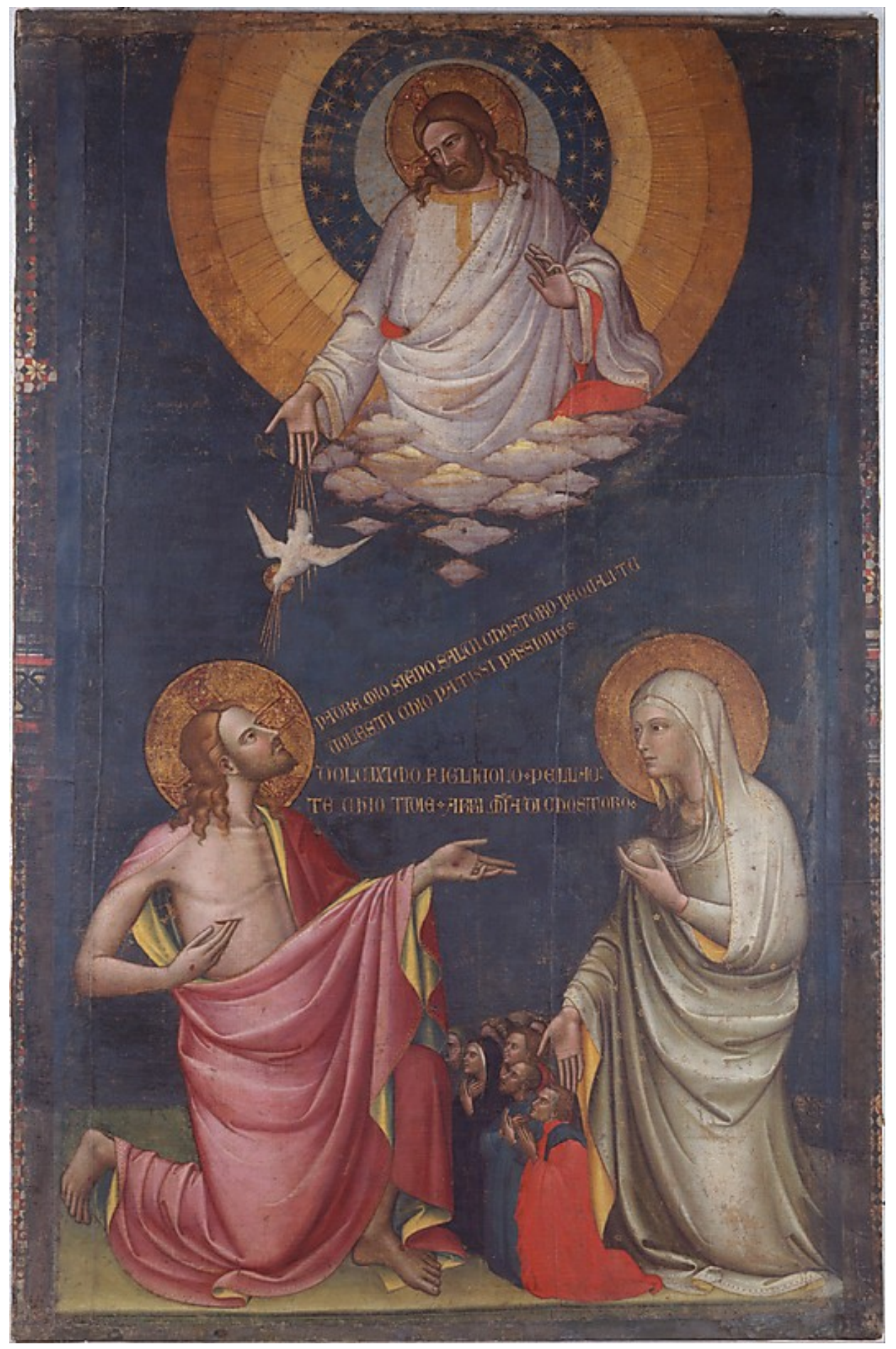

Fig. 4.29. Attributed to Lorenzo Monaco (Piero di Giovanni), The Intercession of Christ and the Virgin, ca. 1402, tempera on canvas, New York Metropolitan Museum of Art. 


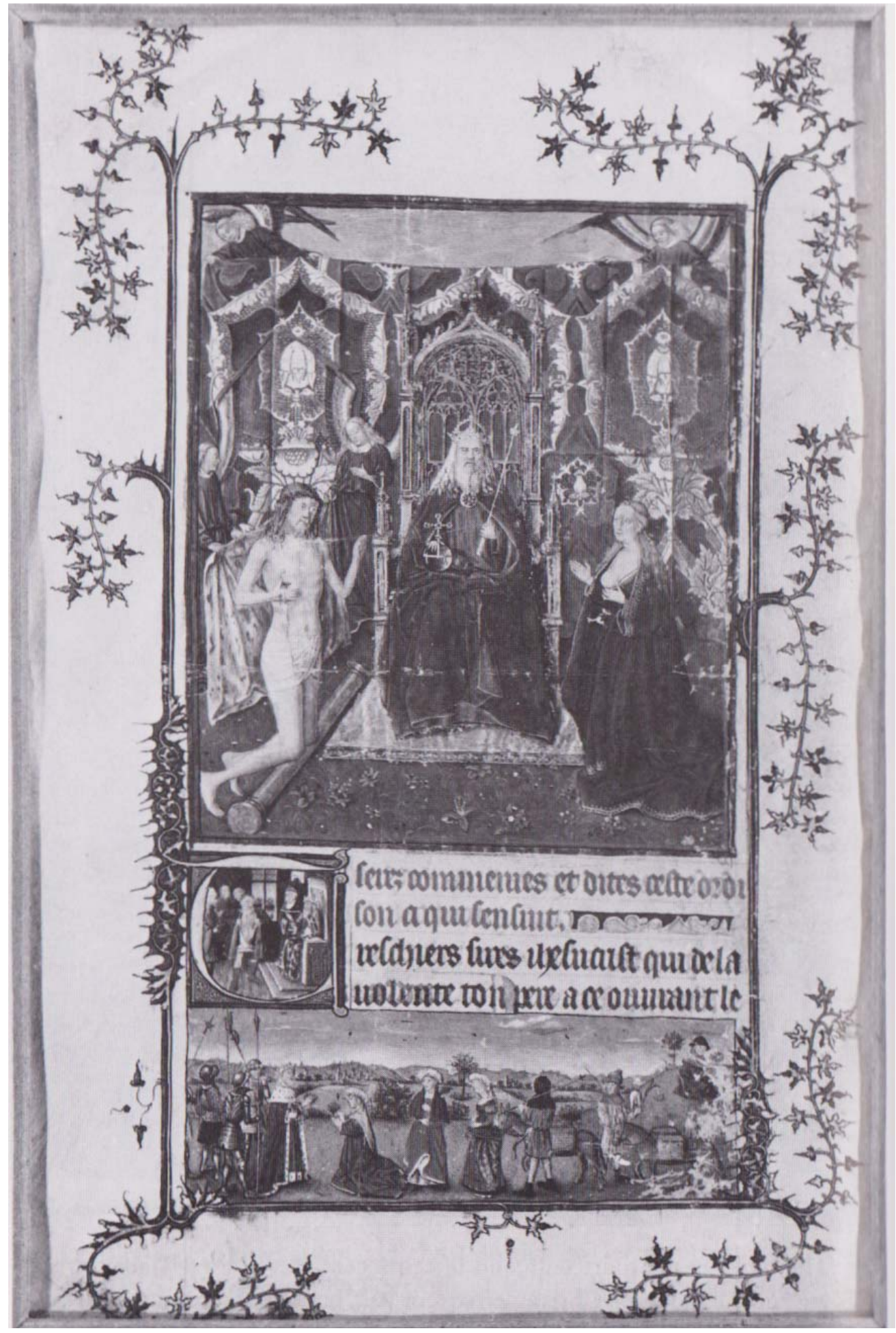

Fig.4.30. Double Intercession, Turin-Milan Book of Hours, mid-fifteenth century, Cabinet des Dessins, Musée du Louvre, Paris. 


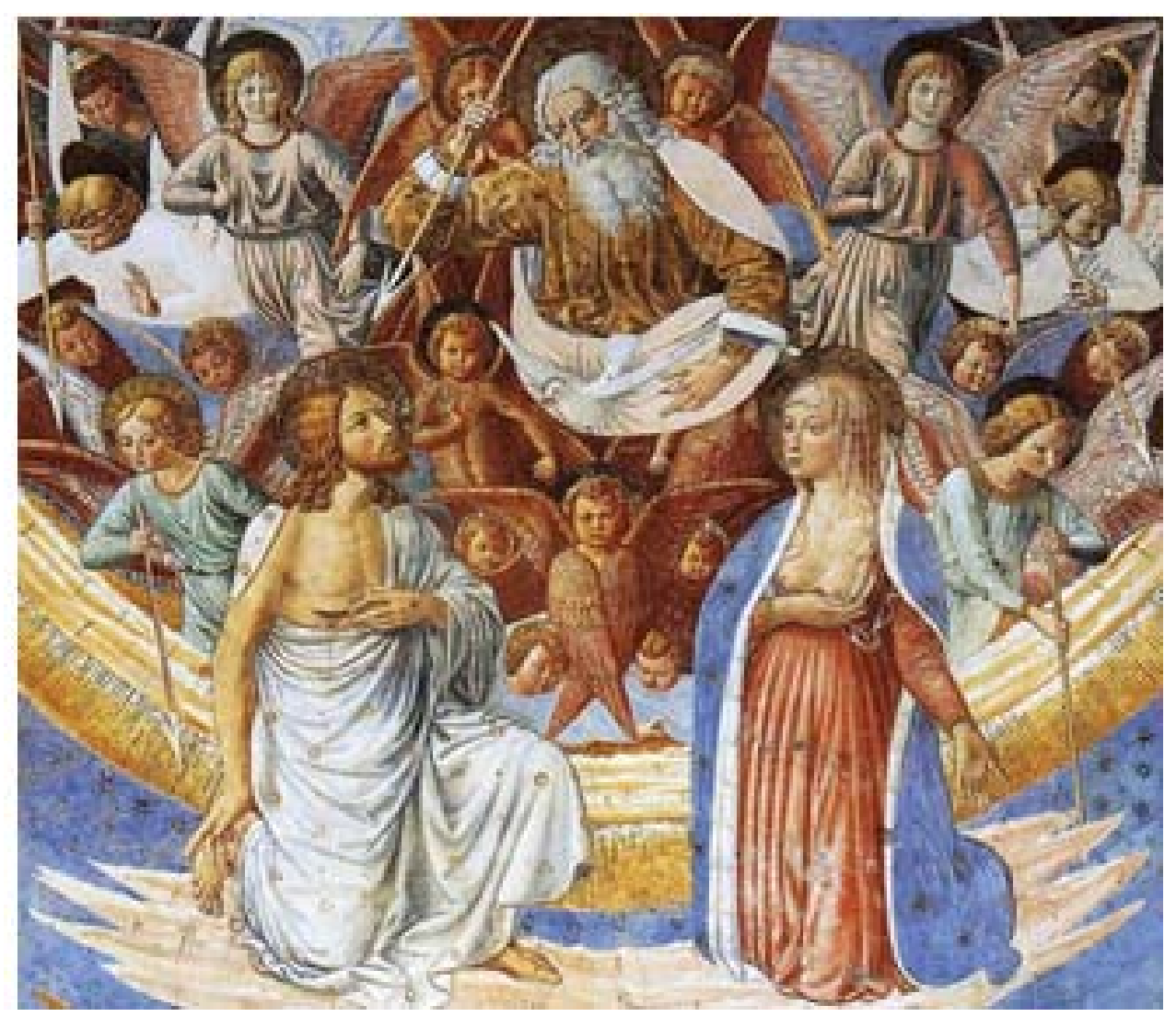

Fig. 4.31. Benozzo Gozzoli, Saint Sebastian, Intercessor, detail, 1464, fresco, Sant'Agostino, San Gimignano. 


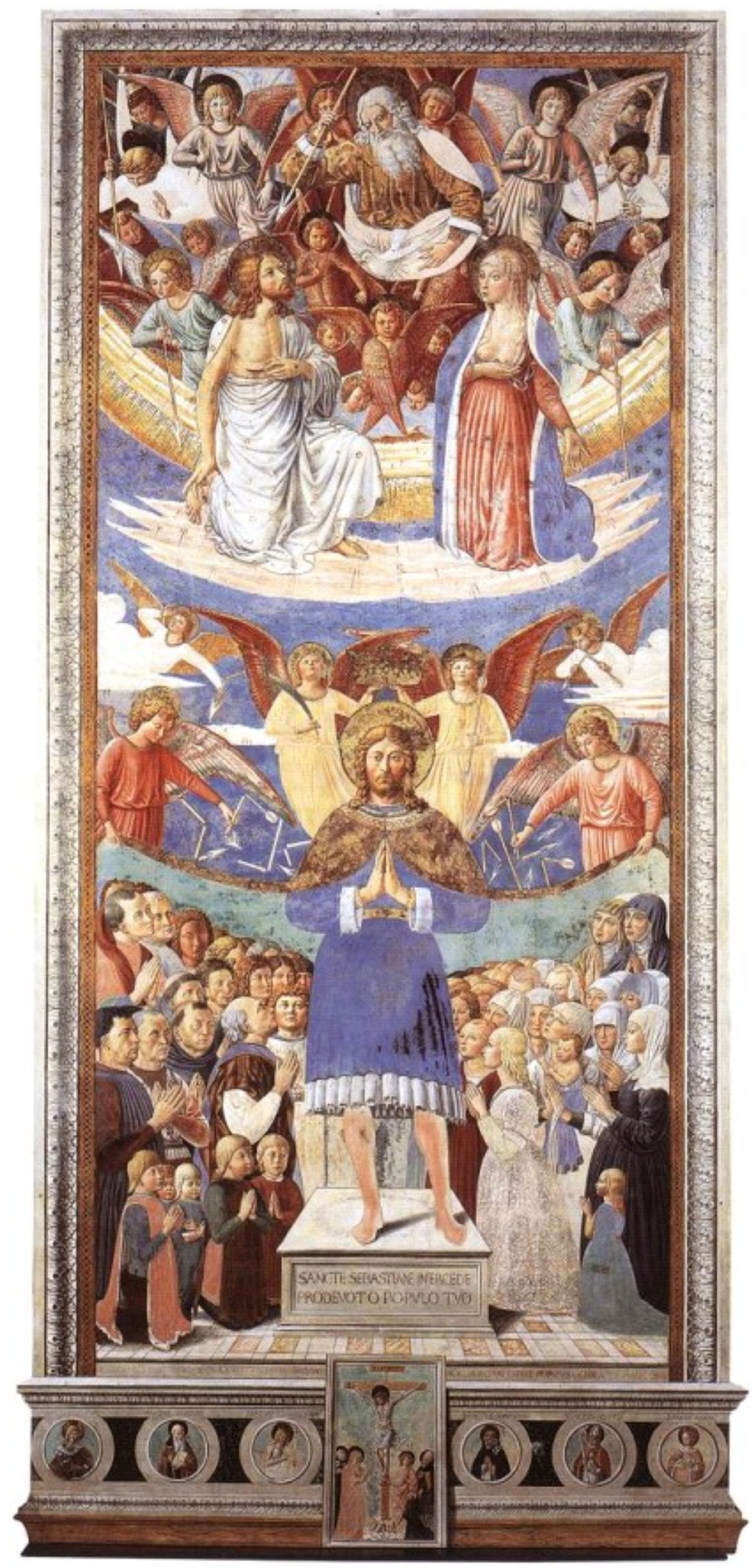

Fig. 4.32. Benozzo Gozzoli, Saint Sebastian, Intercessor, 1464, fresco, Sant'Agostino, San Gimignano. 


\section{$\underline{\text { References }}$}

\section{Primary Sources}

Acta Sanctorum Database. Antwerp and Brussels: Societe des Bollandistes, 1643-1940.

Alberti, Leon Battista. The Family in Renaissance Florence: A translation by Renee Neu Watkins of I libri della famiglia. Columbia, SC: University of South Carolina Press, 1969.

Angela di Foligno, The Book of Divine Consolation of the Blessed Angela of Foligno. Translated by Mary G. Steegmann. New York: Cooper Square Publishers, 1966.

Angela of Foligno. Angela of Foligno Complete Works. Translated by Paul Lachance, O.F.M. Mahwah, NJ: Paulist Press, 1993.

Aquinas, Saint Thomas. On Charity (De caritate). Translated by Lottie H. Kendzierski. Milwaukee: Marquette University Press, 1960.

Aquinas, Thomas. The Sacraments. Vol. 56, Summa Theologice. Translated by David Bourke. New York: Blackfriars - McGraw-Hill Book Company, 1975.

Archives of the Hospital of the Innocents of Florence (Balie a fanciugli A) $(1444-1451)$, n. 5 , c. 3 .

Armenini, Giovanni Battista. "Dei veri precetti della pittura, libro terzo." In Collezione di ottimi scrittori Italiani in supplemento ai classico Milanesi (1587) Pisa: N. Capurro, 1818.

Aulus Gellius. The Attic Nights of Aulus Gellius. Vol. 2. Translated by John C. Rolfe. London: William Heinemann, 1927.

Barbaro, Francesco. “On Wifely Duties.” Translated by Benjamin G. Kohl in The Earthly Republic: Italian Humanists on Government and Society. Edited by Benjamin G. Kohl and Ronald Witt. Philadelphia: University of Pennsylvania Press, 1978.

Bartholomaeus Angelicus. De proprietatibus rerum (On the Properties of Things). Translated by John Trevisa. Oxford: Clarendon Press, 1975. 
Bernardine of Siena. Sermons. Edited by Don Nazareno Orlandi. Translated by Helen Josephine Robins. Siena: Tipografia Sociale, 1920.

Borromeo, Federico. De pictura sacra. Edited and translated by Kenneth S.

Rothwell, Jr. Cambridge, MA.: Harvard University Press, 2010.

Book of Beasts: Being a Translation from a Latin Bestiary of the Twelfth Century. Translated and edited by T. H. White. New York: Dover, 1984.

Davis-Weyer, Caecilia. Early Medieval Art 300 - 1150. Toronto: University of Toronto Press, 1986.

Canons and Decrees of the Council of Trent; Original Text with English Translation. Translated by H. J. Shroeder. St. Louis and London: B. Herder Book Company, 1941.

The Canons and Decrees of the Sacred and Oecumenical Council of Trent, Celebrated under the Sovereign Pontiffs Paul III, Julius III, and Pius IV. Translated by James Waterworth. London: C. Dolman, 1848.

Catherine of Siena, Le Lettere di S. Caterina da Siena. Edited by Piero Misciatelli. Siena: Giutini Bentivoglio \& Co., 1913 - 22.

de Caulibus, Johannes. Meditations on the Life of Christ. Translated and edited by Anne Miller, OSF., Francis Taney, Sr. and C. Mary Stallings-Taney. Asheville, NC: Pegasus Press, 2000.

Celano, Thomas. St. Francis of Assisi: First and Second Life of St. Francis, with selections from Treatise on the Miracles of Blessed Francis. Translated by Placid Hermann,O.F.M. Chicago: Franciscan Herald Press, 1963.

Celano, Thomaso. The Lives of S. Francis of Assisi. Translated by A. G. Ferrers Howell. London: Meuthen \& Co., 1908.

Clement of Alexandria, Christ the Educator. Vol. 23. Translated by Simon P. Wood. New York: Fathers of the Church, 1954.

de Coincy, Gautier. "Miracles of the Blessed Virgin," in Medieval Hagiography. Edited by Thomas Head. New York: Garland Publishing Inc., 2000 .

Cranmer, Thomas. The Remains of Thomas Cranmer, Archbishop of Canterbury. Edited by Henry Jenkyns. Oxford: Oxford University Press, 1833.

Deloney, Thomas. The Works of Thomas Deloney. Edited by Francis Oscar Mann. Oxford: Claredon Press, 1912. 
Durand, Guillaume. Symbolism of Churches and Church Ornaments; A Translation of the First Book of Rationale divinorum officiorum. New York: Scribner, 1893.

Durandus, William. The Symbolism of Churches and Church Ornaments: A Translation of the First Book of the Rationale Divinorum Officiorum. London: T.W. Green, 1843.

Erasmus, Desiderius, Disputatiuncula de taedio, pavore, tristicia Iesu; Concio de immensa Dei misericordia; Modus orandi Deum; Explanatio symboli apostolorum sive catechismus; De praeparatione ad morte. Translated by Michael H. Heath, John N. Grant and Louis A. Perraud. Edited by John W. O’Malley. Toronto: University of Toronto Press, 1998.

Falletti, Fossati, C., Costumi senesi nella secunda meta del secolo quattordicesimo. Siena: 1881. In Women in Italy, 1350 - 1650, Ideals and Realities: A Sourcebook. Selected, Translated, and Introduced by Mary Rogers and Paola Tinagli. Manchester: Manchester University Press, 1995.

Galenus, Claudius. The Translation of Galen's Hygiene. Translated by Robert M. Green, M.D. Springfield, Il.: Charles C. Thomas, Publisher, 1951.

Gerald of Wales. The Jewel of the Church: A Translation of Gemma Ecclesiastica by Giraldus Cambrensis. Translated by John J. Hagen. Leiden: E. J. Brill, 1979.

Gregory I, Pope, ca. 540 - 604. The Dialogues of Saint Gregory. Translated by P.W. to English tongue (1608). Re-edited with introduction and notes by Edmond $\mathrm{G}$. Gardner, M.A. London: P.L. Wagner, 1911.

Guillermus, Altissiodorensis. Summa aurea. Paris: Editions du Centre National de la Recherche Scientifique; Rome: Editions Collegii S. Bonaventurae ad Claras Aquas, $1980-87$.

Herolt, Johannes and C.C. Swinton Bland. Pupil's Storehouse of Miracles of the Blessed Virgin Mary. New York: Harcourt, Brace and Company, 1928.

Hildegard of Bingen. On Natural Philosophy and Medicine: Selections from Cause et cure. Translated by Margret Berger. Cambridge, UK: D. S. Brewer, 1999.

Hippocrates. Aphorism. Translated by Francis Adams. Written in 400 BCE. Section V, 50. http://classics.mit.edu/Hippocrates/aphorisms.5.v.html.

Hugh of Saint Victor. Hugh of Saint Victor on the Sacraments of the Christian Faith (De sacramentis). Translated by Roy J. Deferrari. I,IX, 2 (Cambridge, MA: Medieval Academy of America, 1951. 
Jacobus de Voragine. The Golden Legend. Translated by Granger Ryan and Helmut Ripperger. New York: Arno Press, 1969.

The Koran. M. H. Shakir. Searchable Translation of the Koran. January 2000. 8 April 2007 http://quod.lib.umich.edu/k/koran/browse.html.

Leonardo da Vinci. Leonardo da Vinci: desegni anatomici dalla Biblioteca reale di Windsor. Florence: Giunti-Barbèra, 1979.

---. A Treatise on Painting. Translated by John Francis Rigaud. Amherst, NY: Prometheus Books, 2002.

Luther, Martin. Luther's Works. General Editor, Jaroslav Pelikan. Saint Louis: Concordia Publishing House, 1968.

Maffeo Vegio. Maphei Vegii laudensis De educatione liberorum et eorum claris moribus libri sex; a Critical text of Books I - III. Edited by Maria Walburg Fanning and Anne Stanislaus Sullivan. Washington D.C.: The Catholic University Press, 1933 - 36.

Marino, Giambattista. Dicerie sacre. Venice: Presso Gio: Pietro Brigonci, M.DC.LXVII (1667).

Molanus, Johannes. De picturis et imaginibus sacris (Traité des saintes images). Translated by François Bœspflug, Oliver Christin, and Benoît Tassel. Paris: Cerf, 1996.

Paleotti, Gabriele. Discorso intorno alle imagini sacre et profane. Bologna, 1582.

Palmieri, Matteo. [Libro] Della Vita civile: Ttrattato. Milan: Giovanni Silvestri, 1825. http://babel.hathitrust.org/cgi/pt?id=nnc1.0022851135\#page/iii/mode/1up.

Paolo da Certaldo. Libro di buoni costumi. Edited by Alfredo Schiaffini. Florence: F. Le Monnier, 1945. http://books.google.com/books/about/Libro di_Buoni_Costumi.html.

Pediatrics of the Past: An Anthology. Edited by John Ruhrah. New York: P.B. Hoeber, 1925

Pliny the Elder, The Natural History of Pliny. Vol. II. Translated with notes by John Bostock, M.D. and H.T. Riley. London: Henry G. Bohn, 1855 .

Ragusa, Isa and Rosalie B.Green. Meditations on the life of Christ: An Illustrated Manuscript of the Fourteenth Century. Princeton: Princeton 
University Press, 1961. This is the hitherto unpublished manuscript in the Biblioteque Nationale in Paris (MS.Ital.115).

Raymond of Capua, The Life of Catherine of Siena. Translated by Conleth Kearns. Dublin: Dominican Publications, 1980.

Blessed Raymond of Capua. The Life of Catherine of Siena. Translated by George Lamb. New York: P.J. Kenedy \& Sons, 1960.

Riccoboni, Bartolomea. Life and Death in a Venetian Convent: The Chronicle and Necrology of Corpus Domini, 1395 - 1436. Translated and edited by Daniel E. Bornstein. Chicago: University of Chicago Press, 2000.

Sacchetti, Franco. Il Trecentonovelle, novella LX. Edited by E. Faccioli. Turin: Einaudi, 1970. http://www.letteraturaitaliana.net/pdf/Volume 2/t46.pdf.

Saint Antoninus Pierozzi (attributed to). Libretto della Dottrina Cristiana attribuito a Sant'Antonino arcivescovo di Firenze. Edited by Gilberto Aranci. Florence: A. Pontecorboli, 1996.

Saint Catherine of Siena, The Dialogue. Translated by Suzanne Noffke, O.P. New York: Paulist Press, 1980.

Shinners, John, ed. Medieval Popular Religion 1000-1500: A Reader. Second Edition. Peterborough, ON: Broadview Press, 2007.

Soranus of Ephesus. Soranus' Gynecology. Translated by Owsei Temkin, Nicholson J. Eastman, Ludwig Edelstein, and Alan F. Guttmacher. Baltimore: Johns Hopkins University Press, 1956.

Suarez, Francis, S.J., "The Dignity and Virginity of the Mother of God," from The Mysteries of the Life of Christ, Disputations I, V, VI (1592). Translated by Richard J. O’Brien, S.J. West Baden Springs, IN: West Baden College, 1954.

Vasari, Giorgio. The Lives of the Most Eminent Painters, Sculptors and Architects. Translated by Gaston du C. de Vere. London: MacMillan \& Co., Id. and The Medici Society, Id., 1912 - 1915.

---. The Lives of the Artists. Translated by George Bull. New York: Penguin Books, 1965.

---. Lives of the Painters, Sculptors, and Architects. Translated by Gaston du C. de Vere. New York: Alfred A. Knopf, 1996.

---. The Lives of the Most Eminent Painters, Sculptors and Architects. Edited by Philip Jacks. Translated by Gaston du C. de Vere. New York: The Modern Library, 2006. 
William of Malmesbury, El libro de laudibus et miraculis Sanctae Mariae. Edited by Jose M. Canal. $2^{\text {nd }}$ ed. Rome: Alma Roma, 1968. Quoted in Miri Rubin, Mother of God: A History of the Virgin Mary, New Haven: Yale University Press, 2009, 138.

\section{Secondary Sources}

Adams, Doug, and Diane Apostolos-Cappadona, eds. Art as Religious Studies. New York: Crossroad Publishing Company, 1987.

Alexander-Bidon, Danielle, and Didier Lett. Children in the Middle Ages: Fifth Fifteenth Centuries. Translated by Jody Gladding. Notre Dame, IN: University of Notre Dame Press, 1999.

Antal, Frederick. Florentine Painting and Its Social Background: The Bourgeois Republic Before Cosimo de' Medici's Advent to Power: XIV and Early XV Centuries. London: Kegan Paul, Trench, Trubner \& Co., 1948.

Archer, Madeline Cirillo. The Illustrated Bartsch. Vol. 28. Commentary. Edited by John T. Spike. New York: Abaris Books, 1978.

Ariès, Philippe. Centuries of Childhood: A Social History of Family Life. Translated by Robert Baldick. New York: Knopf, 1962.

Astell, Ann W. Eating Beauty: The Eucharist and the Spiritual Arts of the Middle Ages. Ithaca: Cornell University Press, 2006.

Atkinson, Clarissa, Constance H. Buchanan, and Margaret R. Miles, eds., Immaculate and Powerful: The Female in Sacred Image and Social Reality. Boston: Beacon Press, 1985.

---. The Oldest Vocation: Christian Motherhood in the Middle Ages. Ithaca: Cornell University Press, 1991.

Atlas Database for the The Musée du Louvre. Barnaba da Modena.

http://cartelen.louvre.fr/cartelen/visite? $\mathrm{srv}=$ car_not_frame\&idNotice $=1247 \&$ langue $=$ en.

Baxandall, Michael. Painting and Experience in Fifteenth Century Italy: A Primer in the Social History of Pictorial Style. Oxford: Oxford University Press, 1972.

Becker, Marvin. Medieval Italy: Constraints and Creativity. Bloomington: Indiana University Press, 1981.

Belting, Hans. Likeness and Presence. A History of the Image before the Era of Art. Chicago: University of Chicago Press, 1994.

Bennett, Jill. "Stigmata and the Sense Memory: St. Francis and the Affective 
Image.” Art History 24, no. 1 (March, 2001): 1 - 16.

http://web.ebscohost.com.echo

Berger, John. Ways of Seeing. New York: The Viking Press, 1972.

Berliner, Rudolf. "The Freedom of Medieval Art." Gazette des Beaux-Arts. VI Series XXVII (November, 1945): 263-288.

---. Early Modern Italy: A Social History. London: Routledge, 2001.

Blunt, Anthony. Artistic Theory in Italy 1450 - 1600. Oxford: The Clarendon Press, 1940.

Bonani, Gian Paolo, and Serena Baldassarre Bonani. Maria Lactans. Rome: Edizioni "Marianum,"1995.

Bonano, Salvatore, Rev. "The Concept of Substance and the Development of Eucharistic Theology to the Thirteenth Century." Ph.D. diss., The Catholic University of America, 1960.

Bornstein, Daniel, and Roberto Rusconi, eds. Women and Religion in Medieval and Renaissance Italy. Chicago: University of Chicago Press, 1996.

Borsook, Eve, and Fiorella Superbi Gioffredi, eds. Italian Altarpieces 1250 - 1550: Function and Design. Oxford: Clarendon Press; New York: Oxford University Press, 1994.

Burckhardt, Jacob. The Altarpiece in Renaissance Italy. Edited by Peter Humfrey. Cambridge: Cambridge University Press. 1988.

---. The Civilization of the Renaissance in Italy. Translated by S. G. Middlemore. Oxford: Phaidon, 1965.

Buser, Thomas. "Jerome Nadal and Early Jesuit Art in Rome." The Art Bulletin. 58, no. 3 (September, 1976): 424-433.

Bynum, Caroline Walker. Fragmentation and Redemption: Essays on Gender and the Human Body in Medieval Religion. New York: Zone Books, 1991.

---. Holy Feast and Holy Fast: The Religious Significance of Food to Medieval Women. Berkeley: University of California Press, 1987.

---, Jesus as Mother: Studies in the Spirituality of the High Middle Ages. Berkeley: University of California Press, 1982.

Camille, Michael. Gothic Art Glorious Visions. Upper Saddle River, N.J., Prentice 
Hall, 1996.

---. The Gothic Idol: Ideology and Image Making in Medieval Art. Cambridge and New York: Cambridge University Press, 1989.

Carroll, Michael P. Madonnas that Maim: Popular Catholicism in Italy Since the Fifteenth Century. Boston: The Johns Hopkins University Press, 1992.

Carruthers, Mary. The Book of Memory: A Study of Memory in Medieval Culture. Cambridge, UK: Cambridge University Press, 2008.

Chidester, David. Word and Light: Seeing, Hearing, and Religious Discourse. Urbana and Chicago: University of Illinois Press, 1992.

Cleves, Msgr. William F. Stories in Glass: The Windows of the Cathedral Basilica of the Assumption, Covington, Kentucky. Covington, KY: The Cathedral Foundation, 2009.

Coakley, John. "Gender and the Authority of Friars: The Significance of Holy Women for Thirteenth Century Franciscans and Dominicans." Church History, 60 (1991): 445-60.

Coleman, Earle J. Creativity and Spirituality: The Bonds between Art and Religion. Albany, NY: The State University of New York Press, 1998.

Coletti, Theresa. "Purity and Danger: The Paradox of Mary's Body and the En-gendering of the Infancy Narrative in the English Mystery Cycles." In Feminist Approaches to the Body in Medieval Literature. Edited by Linda Lomperis and Sarah Stanbury. Philadelphia: University of Pennsylvania Press, 1993.

Colon, A.R. A History of Children: A Socio-Cultural Survey across Millennia. Westport, Connecticut: Greenwood Press, 2001.

Connell, William J., and Giles Constable. "Sacrilege and Redemption in Renaissance Florence: The Case of Antonio Rinaldeschi." Journal of the Warburg and Courtauld Institutes, 61 (1998): 53-92.

Coolman, Boyd Taylor. Knowing God by Experience: The Spiritual Senses in the Theology of William of Auxerre. Washington, D.C.: Catholic University of America Press, 2004.

Crawford, Amy. "Who was Cleopatra? Mythology, Propaganda, Liz Taylor and the Real Queen of the Nile," Smithsonian.com (April 1, 2007). http://www.smithsonianmag.com/history-archaeology/.../cleopatra.html. 
Dabbs, Julia K. Life Stories of Women Artists, 1550 - 1800, An Anthology. Burlington, VT: Ashgate, 2009.

Darvas, György. Symmetry: Cultural-historical and Ontological Aspects of Science-Arts Relations: the Natural and Man-made World in an Interdisciplinary Approach. Translated by David Robert Evans. Basel: Birkhauser, 2007.

Dean, Trevor and Kate Lowe. "Writing the History of Crime in the Italian Renaissance." In Crime, Society and the Law in Renaissance Italy. Edited by Trevor Dean and K.J.P. Lowe. Cambridge: Cambridge University Press, 1994.

Debby, Nirit Ben-Aryeh. Renaissance Florence in the Rhetoric of Two Popular Preachers: Giovanni Dominici and Bernardino da Siena. Turnhout, Belgium: Brepols, 2001.

Delehaye, Hippolyte. The Legends of the Saints. New York: Fordham University Press, 1962.

Demaitre, Luke. "The Idea of Child Care in the Medical Writings of the Middle Ages." Journal of Psychohistory IV (1977): 461-90.

Derbes, Anne, and Mark Sandona. “"Ave charitate plena': Variations on the Theme of Charity in the Arena Chapel." Speculum, 76, no.3 (July, 2001): 599-637.

Despres, Denise, "Franciscan Spirituality: Margery Kemp and Visual Meditation." Mystics Quarterly 11, no. 1 (March 1985): 12 - 18.

Dix, Gregory. The Shape of the Liturgy. London: A. \& C. Black, Ltd. Dacre Press, 1945.

Ellington, Donna Spivey. From Sacred Body to Angelic Soul: Understanding Mary in Late Medieval and Early Modern Europe. Washington, D. C: Catholic University of America Press, 2001.

Evangelisti, Silvia." Rooms to Share: Convent Cells and Social Relations in Early Modern Italy." In The Art of Survival: Gender and History in Europe, 1450 2000. Edited by Ruth Harris and Lyndal Roper. Oxford: Oxford University Press, 2006.

Etienne, Robert. "Ancient Medical Conscience and the Life of Children." Journal of Psychohistory IV (1977): 131-161.

ffollitt, Sheila. "Wife, Widow, Nun, and Court Lady: Women Patrons of the Renaissance and Baroque." In Italian Women Artists from Renaissance to Baroque. Edited by Elizabeth S. G. Nicholson, Rebecca Price, Jane McAllister, and Karen I. Peterfreund. Milan: Skira Editore S.p.A., 2007. 
Fildes, Valerie. Breasts, Bottles and Babies: A History of Infant Feeding. Edinburgh: Edinburgh University Press, 1986.

---. Wet Nursing: A History from Antiquity to Present. Oxford: Basil Blackwell, 1988.

Fischer, Chris. Fra Bartolommeo: Master Draughtsman of the High Renaissance. A Selection from the Rotterdam Albums and Landscape Drawings from Various Collections. Rotterdam: Museum Boymans-van Beuningen, 1990.

Fish, Stanley. Is There a Text in this Class? The Authority of Interpretive Communities. Cambridge, MA: Harvard University Press, 1980.

Follmar, Mary Ann. The Steps of Love in the Dialogue of St. Catherine of Siena. Petersham, MA.: St. Bede Publications, 1987.

Forsyth, Ilene. "Children in Early Medieval Art: Ninth through Twelfth Centuries." Journal of Psychohistory IV (1977): 31-70.

Frantz, David O. Festum voluptatis: A Study of Renaissance Erotica. Columbus, Ohio: Ohio State University Press, 1989.

Freedberg, David. The Power of Images: Studies in the History and Theory of Response. Chicago: University of Chicago Press, 1989.

---. Sanctarum imaginum et picturarum, Book II, Chapter 42." Journal of the Warburg and Courtauld Institutes. 34 (1971): 229-45.

Freyhan, R. "The Evolution of the Caritas Figure in the Thirteenth and Fourteenth Centuries." Journal of the Warburg and Courtauld Institutes, 11 (1948): 68 - 86.

Fulton, Christopher B. An Earthly Paradise: The Medici, Their Collections and the Foundations of Modern Art. Florence, Italy: Leo S. Olschki, 2006.

---. "The Master IO F.F.and the Function of Plaquettes." In Italian Plaquettes. Vol. 22, Studies in the History of Art. Washington D.C.: National Gallery of Art, 1989.

Fulton, Rachel. From Judgment to Passion: Devotion to Christ and the Virgin Mary, 800-1200. New York: Columbia University Press, 2002.

Gabrovsky, Vanessa Elena. "Chaste Sexuality in Saint Bernard's Vision and the Multiplicity of Mary's Breast." MA thesis, University of California, Los Angeles, 2004. 
Gavitt, Philip. Charity and Children in Renaissance Florence: The Ospedale degli Innocenti, 1410 - 1536. Ann Arbor: University of Michigan Press, 1990.

Geetz, Clifford. "Thick Description: Toward an Interpretive Theory of Culture.” In The Interpretation of Cultures. New York: Basic Books, 1973.

Gilbert, Creighton E. Italian Art 1400 - 1500: Sources and Documents. Englewood Cliffs, N.J.: Prentice Hall, 1980.

---. "Tuscan Observants and Painters in Venice, ca. 1400." In Interpretazioni veneziane: Studi di storia dell'arte in onore di Michelangelo Muraro. Venezia: Arsenale Editrice, 1984.

Goffen, Rona. "Mary's Motherhood According to Leonardo and Michelangelo." Artibus et Historiae 40, no. 20 (1999): 35 - 69.

Goldthwaite, Richard. Wealth and the Demand for Art in Italy 1300 - 1600. Baltimore: Johns Hopkins University Press, 1993.

Graef, Hilda. The Devotion to Our Lady. New York: Hawthorn Books, 1963.

---. Mary: A History of Doctrine and Devotion. London: Sheed and Ward, 1963.

Grendler, Paul. "Form and Function in Italian Renaissance Popular Books." Renaissance Quarterly 46, no. 3 (Autumn 1993): $451-485$.

Greyerz, Kasper von. Religion and Culture in Early Modern Europe 1500-1800. New York: Oxford University Press, 2008.

Grillo, Michael. Symbolic Structures: The Role of Composition in Signaling Meaning in Italian Medieval Art. New York: Peter Lang Publishing, 1997.

Haas, Louis. The Renaissance Man and his Children: Childbirth and Early Childhood in Florence, 1300 - 1600. New York: St. Martin's Press, 1998.

Hahn, Cynthia. "Visio Dei Changes in Medieval Visuality." In Visuality Before and Beyond the Renaissance: Seeing as Others Saw. Edited by Robert S. Nelson. Cambridge: Cambridge University Press, 2000.

Hale, Rosemary."Imitatio Mariae: Motherhood Motifs in Devotional Memoirs." Mystics Quarterly, 16, no. 4 (December, 1990): 193 - 203.

Hall, Marcia B. "The Ponte in S. Maria Novella: The Problem of the Rood Screen in Italy." Journal of the Warburg and Courtauld Institutes. 37 (1974): 157-173. 
Hamburger, Jeffrey F., Nuns as Artists: The Visual Culture of a Medieval Convent. Berkeley and Los Angeles: University of California Press, 1997.

Hanawalt, Barbara. Growing Up in Medieval London: The Experience of Childhood in History. New York: Oxford University Press, 1993.

Hatfield, Rab. "Botticelli's Mystic Nativity, Savonarola and the Millennium." Journal of the Warburg and Courtauld Institutes. 58, (1995): 88 - 114.

Hawkins, Stephen. "The Blood of Christ in the Life and Works of Saint Catherine of Siena: A Spiritual, Scriptural, Historical, Reflection Study.” M.A. Thesis, Mount Saint Mary Seminary of the West, The Athenaeum of Ohio, 1974.

Heal, Bridget. "Images of Mary and Marian Devotion in Protestant Nuremberg." In Religion and Superstition in Reformation Europe. Edited by Helen Parish, and William G. Naphy. Manchester and New York: Manchester University Press, 2002.

Henry, Tom, and Laurence Kanter. Luca Signorelli: The Complete Paintings. New York: Rizzoli International Publications, 2002.

Herlihy, David. Opera Muliebria: Women and Work in Medieval Europe. Philadelphia: Temple University Press, 1990.

---.Women, Family and Society in Medieval Europe: Historical Essays 1987 - 1991. Providence: Berghahn Books, 1995.

Herlihy, David and Christiane Klapisch-Zuber. Tuscans and Their Families: A Study of the Florentine Catasto of 1427. New Haven and London: Yale University Press, 1985.

Hirn, Yrjo. The Sacred Shrine; a Study of the Poetry and Art of the Catholic Church. Boston: Beacon Press, 1957.

Hollander, Anne. Seeing Through Clothes. New York: Viking, 1978.

Holmes, Megan. "Disrobing the Virgin: The Madonna Lactans in Fifteenth-Century Florentine Art." In Picturing Women in Renaissance and Baroque Italy. Edited by Geraldine A. Johnson, and Sara F. Matthews Grieco. Cambridge: Cambridge University Press, 1997.

Holt, Elizabeth Basye Gilmore. A Documentary History of Art. Garden City, NY: Doubleday \& Co., Inc., 1957.

Horkan, Vincent J. Educational Theories and Principals of Maffeo Vegio. Washington, D.C: Catholic University of America Press, 1953. 
Humfrey, Peter, and Martin Kemp, eds. The Altarpiece in the Renaissance. Cambridge: Cambridge University Press, 1990.

Hunt, Alan. Governance of the Consuming Passions: A History of Sumptuary Law. New York: St. Martin's Press, 1996.

Hunt, David. Parents and Children in History: The Psychology of Family Life in Early Modern France. New York: Basic Books, Inc., 1970.

Just, Felix S.J., Basic Texts for the Roman Catholic Eucharist, Eucharistic Prayers $I-I V$, from the English translation of The Roman Missal (C) 1973, International Committee on English in the Liturgy, Inc., January 8, 2010 http://catholicresources.org/ChurchDocs/EP1-4.htm.

Kasl, Ronda, "Holy Households: Art and Devotion in Renaissance Venice," In Giovanni Bellini and the Art of Devotion. Indianapolis: Indianapolis Museum of Art, 2004.

Kay, Sarah, and Miri Rubin, eds. Framing Medieval Bodies. Manchester: Manchester University Press, 1994.

Kelly-Gadol, Joan. “Did Women have a Renaissance?” In Becoming Visible: Women in European History. Edited by Renate Bridenthal and Claudia Koonz. Boston: Houghton Mifflin, 1977.

Kent, Dale V., and Francis William Kent. Neighbours and Neighbourhood in Renaissance Florence: The District of the Red Lion in the Fifteenth Century. Locust Valley, NY: J. J. Augustin, for Villa I Tatti, 1982.

Kent, Francis William. Household and Lineage in Renaissance Florence: The Family Life of the Capponi, Ginori and Rucellai. Princeton: Princeton University Press, 1977.

Kertzer, David I. Sacrificed for Honor: Italian Infant Abandonment and the Politics of Reproductive Control. Boston: Beacon Press, 1993.

King, Georgiana Goddard. "The Virgin of Humility." The Art Bulletin 17, no. 4 (December, 1935): 474-91.

Klein, Robert and Henry Zerner. "The Council of Trent on Religious Art," Italian Art 1500-1600: Sources and Documents. Englewood Cliffs, N.J.: Prentice Hall, 1966.

Klapisch-Zuber, Christiane. "Blood Parents and Milk Parents." In Women, Family, and Ritual in Renaissance Italy. Translated by Lydia Cochraine. Chicago: 
University of Chicago Press, 1985.

---. "Parenti, Amici, e Vicini: il territorio urbano d'una famiglia mercantile nel XV secolo," Quaderni storici, XXXIII (1976): 953-82.

Klauser, Theodore. A Short History of the Western Liturgy, Second edition. Oxford: Oxford University Press, 1979.

Koerner, Joseph Leo. The Reformation of the Image. Chicago: University of Chicago Press, 2004.

Kren, Emil and Daniel Marx. Gozzoli, Benozzo, Saint Sebastian, Intercessor. http://www.wga.hu/frames-e.html?/html/g/gozzoli/5various/4interce.html.

Kristeller, Paul. Andrea Mantegna. Translated by Sanford Arthur Strong. London: Longmans, Green and Co., 1901.

La Leche League International, "What is Colostrum? How Does it Benefit My Baby? http://www.1lli.org/FAQ/colostrum.html.

Lane Barbara. The Altar and the Altarpiece: Sacramental Themes in Early Netherlandish Painting. New York: Harper \& Row, 1984.

Lasareff, Victor. "Studies in the Iconography of the Virgin." The Art Bulletin. 20 (1938): $25-65$.

Laurentin, Rene. The Question of Mary. Translated by I. G. Pidoux. New York: Holt, Rinehart and Winston, 1963.

Levin, William, R. "Advertising Charity in the Trecento: The Public Decorations of the Misericordia in Florence." Studies in Iconography 17 (1996): 215-309.

---. "'Lost Children,' A Working Mother, and the Progress of an Artist in the Florentine Misericordia in the Trecento." Publications of the Medieval Association of the Midwest 6 (1999): 34-84.

---. "Studies in the Imagery of Mercy in Late Medieval Italian Art." Ph.D. diss., University of Michigan, 1983.

Lomperis, Linda, and Sarah Stanbury, eds. Feminist Approaches to the Body in Medieval Literature. Philadelphia: University of Pennsylvania Press, 1993.

Lowe, K. J. P., Nuns' Chronicles and Convent Culture in Renaissance and CounterReformation Italy. Cambridge: Cambridge University Press, 2003.

Lydecker, John Kent. "The Domestic Setting of the Arts in Renaissance Florence," Ph.D. diss., Johns Hopkins University, 1987. 
MacCaskey, Laura. "Triumph and Martyrdom: Counter Reformation Politics in a Farnese Altarpiece.” Konsthistorisk Tidskrift. 75, no. 3 (2006): 167-81.

MacMichael,Brian. “The New Translation of the Holy Mass." Today's Catholic News. http://www.todayscatholicnews.org/2011/02/the-new-translation-of-the holy-mass-12.

Macy, Gary. The Theologies of the Eucharist in the Early Scholastic Period. New York: Oxford University Press, 1984.

Mâle, Emile. Religious Art in France of the Thirteenth Century. Translated by Dora Nussey. New York: E. P. Dutton \& Co., 1913.

Manning, J.T., D. Scutt, G.H. Whitehouse, S.J. Leinster, and J. M. Walton. "Asymmetry and the Menstrual Cycle in Women," Ethology and Sociobiology. 17, no. 2 (1996): $129-143$.

Marquand, Allan. Andrea della Robbia and his Atelier. Vol. 1. Princeton: Princeton University Press, 1922. http://catalog.hathitrust.org/Record/001981811.

Martines, Lauro. "The Italian Renaissance Tale as History." In Language and Images in Renaissance Italy. Edited by Alison Brown. Oxford: Clarendon Press, New York: Oxford University Press, 1995.

---. Power and Imagination: City States in Renaissance Italy. New York: Knopf, 1979.

Mayes, Frances. Under the Tuscan Sun. New York: Broadway Books, 1996.

Mazza, Angelo. Guido Reni 1575-1642. Los Angeles and Bologna: Los Angeles County Museum of Art and Nuova Alfa Editoriale, 1988.

McDannell, Colleen, and Bernhard Lang. Heaven: A History. New Haven and London: Yale University Press, 1988.

McHugh, Joan Carter. Eucharist, God Among Us. Essays and Images of the Eucharist in Sacred History. Lake Forest, Il.: Witness, 1999.

McLaughlin, Mary Martin. "Survivors and Surrogates." The History of Childhood. Edited by Lloyd deMause. New York: The Psychohistory Press, 1974.

Meehan, Andrew. "Pax." In The Catholic Encyclopedia. Vol. 11. New York: Robert Appleton Company, 1911. http://www.newadvent.org/cathen/11594b.htm.

Meiss, Millard. "The Madonna of Humility.” The Art Bulletin 18, no. 4 (December, 
1936): $435-64$.

Migne, Jaques-Paul. Index alphabeticus omnium doctorum, patrum, scriptorumque ecclesiasticorum quorum opera scriptaque vel minima in Patrologia Latina reperiuntur. Ridgewood, NJ: Gregg Press, 1965.

Miles, Margaret. A Complex Delight: The Secularization of the Breast, 1350-1750. Berkeley: University of California Press, 2008.

---. Image as Insight. Boston: Beacon Press, 1985.

---. "Nudity, Gender and Religious Meaning in the Italian Renaissance." In Art as Religious Studies. Edited by Doug Adams and Diane Apostolos-Cappadona. New York: Crossroads Publishing Company, 1987.

---. Rereading Historical Theology: Before, During, and After Augustine. Eugene, OR: Cascade Books, 2008.

Miller, John D. Beads and Prayers: The Rosary in History and Devotion. London and New York: Burns and Oates, 2002.

Miller, Naomi, and Naomi Yavneh. Maternal Measures: Figuring Caregiving in the Early Modern Period. Burlington, VT: Ashgate, 2000.

Mineo, Tommaso Claudio. La Spada e il latte, Genoa: San Giorgio Editrice, S.p.A., 2008.

Moorman, Mary C. "A Theological Reading of Medieval Vessels as Emblems of Embrace." In Perspectives on Medieval Art, Learning through Looking. Edited by Ena Giuescu Heller and Patricia C. Pongracz. New York: Museum of Biblical Art, 2010.

Mormando, Franco. The Preacher's Demons. Bernardino of Siena and the Social Underworld of Early Renaissance Italy. Chicago: University of Chicago Press, 1999.

Muir, Edward, and Ronald F. E. Weissman. "Social and Symbolic Places in Renaissance Venice and Florence." In The Power of Place: Bringing together Geographical and Sociological Imaginations. Edited by John A. Agnew, and James S. Duncan. Boston: Unwin Hyman, Inc., 1989.

Muir, Edward, "The Virgin on the Street Corner: The Place of the Sacred in Italian Cities." In Religion and Culture in the Renaissance and Reformation. Edited by Steven Ozment. Kirksville, Mo.: Sixteenth Century Journal Publishers, XI, 1989.

Mulvaney, Beth A. "The Beholder as Witness: The Franciscan Crib at Greccio from 
the Upper Church at San Francesco, Assisi, and Franciscan Influence on Late Medieval Art in Italy." In The Art of the Franciscan Order in Italy. Edited by William Cook. Leiden: Koninklijke Brill NV, 2005.

Mulvey, Laura."Visual Pleasure and Narrative Cinema." In Issues in Feminist Film Criticism. Edited by Patricia Erens. Bloomington: Indiana University Press, 1990.

Musallam, Basim. Sex and Society in Islam, Birth Control Before the Nineteenth Century. Cambridge: Cambridge University Press, 1983.

Nelson, Jonathan K. Ed. Plautilla Nelli (1524 - 1588) The Painter and the Prioress. Syracuse: Syracuse University Press, 2008.

---, ed. Suor Plautilla Nelli (1523 - 1588). The First Woman Painter of Florence. Fiesole: Edizione Cadmo, 2000.

Newbery, Timothy J., George Bisacca, and Laurence B. Kanter. Italian Renaissance Frames. New York: Metropolitan Museum of Art, 1990.

Newman, Barbara. From Virile Woman to WomanChrist: Studies in Medieval Religion and Literature. Philadelphia: University of Pennsylvania Press, 1995.

Nocentini, Serena. Museo Benozzo Gozzoli, http://www.museobenozzogozzoli.it/works/SaintSebastian.html.

Norman, Diana. Siena and the Virgin: Art and Politics in a Late Medieval City State. New Haven, London: Yale University Press, 1999.

Offner, Richard. Studies in Florentine Painting: The Fourteenth Century. New York: Junius Press, 1927.

O’Malley, John W. The First Jesuits. Cambridge: Harvard University Press, 1993.

O’Neill, W. Patrick. "The Marian Art of Da Vinci, Michelangelo, and Raphael with a Prologue on Aspects of Marian Art in Comparison with Pre-Christian Deities." M.A. Thesis. Bloomsburg University. 1984.

Origo, Iris. The Merchant of Prato, Francesco di Marco Datini (1335 -1410). New York: Alfred A. Knopf, Inc., 1957.

--- The World of San Bernardino. New York: Harcourt Brace \& World, 1962.

Orme, Nicholas. From Childhood to Chivalry: The Education of English Kings and Aristocracy, 1066-1530. London: Methuen, 1984.

---. Medieval Children. New Haven: Yale University Press, 2003. 
Os, Henk van. The Art of Devotion in the Late Middle Ages in Europe 1300-1500. London: Merrell Holberton, 1994.

---. Sienese Altarpieces 1215 - 1460 Volumes I and II. Groningen: Bouma's Boekhuis bv, 1984 and 1990.

---. Visions of Holiness: Art and Devotion in Renaissance Italy. Edited by Andrew Ladis, and Shelley E. Zuraw; introduction by Henk van Os. Athens, GA: Georgia Museum of Art, University of Georgia, c. 2001.

Osborne, John. "The Dado Programme in Giotto's Arena Chapel and Its Italian Romanesque Antecedents.” The Burlington Magazine 145, no. 1202 (May, 2003): $361-365$.

Ozment, Steven. The Age of Reform(1250-1550): An Intellectual and Religious History of Late Medieval and Reformation Europe. New Haven: Yale University Press, 1980.

Palmer, Allison Lee. "The Walters' Madonna and Child Plaquette and Private Devotional Art in Early Renaissance Italy" The Journal of the Walters Art Museum 59 (2001): 73 - 84.

Panofsky, Erwin. "Erasmus and the Visual Arts." Journal of the Warburg and Courtauld Institutes 32 (1969): 200 - 227.

---. Meaning in Visual Arts. Garden City, NY.: Doubleday \& Co., Inc., 1939.

Paoletti, John T., and Gary M. Radke. Art in Renaissance Italy. Second Edition. Upper Saddle River, NJ: Harry N. Abrams, 2002.

Paolucci, Antonio. Luca Signorelli. Edited and translated by Lisa Pelletti. Florence: SCALA, 1990.

Payne, Blanche. History of Costume. New York: Harper \& Row Publishers, 1965.

Pelikan, Jaroslav. Mary Through the Centuries: Her Place in the History of Culture. New Haven: Yale University Press, 1996.

Petroff, Elizabeth Alvilda. Body and Soul: Essays on Medieval Women and Mysticism. New York: Oxford University Press, 1994.

Petzold, Andreas. Romanesque Art. New York: Harry N. Abrams, 1995.

Piccini, Attilio. Spedale e Museo degli Innocenti. Florence: "Lo Studiolo," 1977. 
Pierattini, Giovanna. Suor Plautilla Nelli, Pittrice Domenicana. Firenze: Convento S. Maria Novella, 1938.

Polizzotto, Lorenzo. The Elect Nation: The Savonarolan Movement in Florence 1494 - 1545. Oxford: Clarendon Press, 1994.

Pope- Hennessy, John. Donatello Sculptor. New York: Abbeville Press, 1993.

--- "The Study of Italian Plaquettes." In Italian Plaquettes. Edited by Alison Luchs. Studies in the History of Art. Vol. 22. Washington D.C.: National Gallery of Art, 1989.

Ragionieri, Pina. Casa Buonarroti. Milan: Mondadori Electa, S.p.A., 2009.

Rahner, Karl. Theological Investigations Vol. XVI, Experience of the Spirit: Source of Theology. Translated by David Moreland O.S.B. New York: The Seabury Press, 1979.

Randolph, Adrian W. B. "Gendering the Period Eye: Deschi da Parto and Renaissance Culture.” Art History 27, no. 4 (September, 2004): 538 - 562.

Reames, Sherry. The Legenda Aurea. Madison: University of Wisconsin Press, 1985.

Ringbom, Sixten. Icon to Narrative: The Rise of the Dramatic Close-up in FifteenthCentury Devotional Painting. Second edition. The Netherlands: Davaco Publishers, 1985.

Roberts, Ann. Dominican Women and Renaissance Art: The Convent of San Domenico. Aldershot, Hampshire: Ashgate, 2008.

Rogers, Mary, and Paola Tinagli, eds. Women in Italy, 1350 - 1650, Ideals and Realities: A Sourcebook. Manchester: Manchester University Press, 2005.

Rosenthal, Erwin. "The Crib of Greccio and Franciscan Realism." The Art Bulletin 36 (March 1954): 57-60.

Ross, James Bruce. "The Middle-Class Child in Urban Italy, Fourteenth to Early Sixteenth Century." The History of Childhood. Edited by Lloyd deMause. New York: The Psychohistory Press, 1974.

Rubin, Miri. Corpus Christi: The Eucharist in Late Medieval Culture. Cambridge: Cambridge University Press, 1991.

---. The Mother of God: A History of the Virgin Mary, New Haven: Yale University Press, 2009. 
Schiff, Stacy. Cleopatra: A Life. New York: Little Brown and Company, 2010.

Seasonwein, Johanna G. "The Nursing Queen: Sculptures of the Virgo Lactans in Late Medieval France.” Ph.D. diss., Columbia University, 2010.

Seubert, Xavier John OFM, STD. "Liturgical Instruments and the Placing of Presence." In Perspectives on Medieval Art: Learning through Looking, edited by Ena Giurescu Heller and Patricia C. Pongracz, 137 - 145. London: Museum of Biblical Art, 2010.

Shah, Mazhar H. General Principals of Avicenna's Canon of Medicine. Pakistan: Inter Services Press, 1966.

Shahar, Shulamith. The Fourth Estate: A History of Women in the Middle Ages. Translated by Chaya Galai. London: Methuen \& Co, 1983.

---. "Infants, Infant Care, and Attitudes toward Infancy in the Lives of Medieval Saints." Journal of Psychohistory X (1983): 281-309.

Shearman, John. Only Connect: Art and the Spectator in the Italian Renaissance. Princeton: Princeton University Press, 1992.

Shorr, Dorothy C. The Christ Child in Devotional Images in Italy During the XIV Century. New York: G.Wittenborn, 1954.

Simoni, Serena, "Una nuova 'Madonna del Latte' di Barbara Longhi.” Romagna arte e storia 24, no. 71 (2004): 105-112.

Sinanoglou, Leah. "The Christ Child as Sacrifice: A Medieval Tradition and the Corpus Christi Plays. Speculum 48, no. 3 (July 1973): 491-509.

Singh, Devendra. "Female Health, Attractiveness, and Desirability for Relationships: Role of Breast Asymmetry and Waist to Hip Ratio." Ethology and Sociobiology 16, no. 6 (November, 1995): 465-81.

Spear, Richard E. The "Divine” Guido: Religion, Sex, Money and Art in the World of Guido Reni. New Haven and London: Yale University Press: 1997.

Steele, Robert. Mediaeval Lore from Bartholomaeus Angelicus. New York: Cooper Square Publishers, 1966.

Steinberg, Leo. The Sexuality of Christ in Renaissance Art and in Modern Oblivion. New York: Pantheon Books, 1984.

Steinberg, Ronald. Fra Girolamo Savonarola, Florentine Art, and Renaissance Historiography. Athens, OH: Ohio University Press, 1977. 
Steinhoff, Judith. Sienese Painting after the Black Death: Artistic Pluralism, Politics, and the Art Market. Cambridge: Cambridge University Press, 2006.

Stevens-Arroyo, Anthony M. "The Evolution of Marian Devotionalism within Christianity and the Ibero-Mediterranean Polity." Journal of the Scientific Study of Religion 37, no. 1 (March 1998): 50-73.

Swan-Jones, Lois, and Preston Jones. "The Virgin Mary in Art: Renaissance to Reformation.” In The Development of Christian Symbolism. Dallas: Swan/Jones Productions. Copyright, 1996.

Syson, Luke with Larry Keith. Leonardo da Vinci: Painter at the Court of Milan. London: National Gallery Company, 2011.

Tetlow, Joseph A., S.J. Ignatius Loyola: Spiritual Exercises. New York: The Crossroad Publishing Company, 1992.

Thomas, Anabel. Art and Piety in the Female Religious Communities of Renaissance Italy. Cambridge: Cambridge University Press, 2003.

Trexler, Richard C. "Florentine Religious Experience: The Sacred Image." Studies in the Renaissance 19 (1972): 7 - 41.

---. “The Foundlings of Florence, 1395 - 1455." The History of Childhood Quarterly 1 (1973): $259-284$.

---. "Infanticide in Florence: New Sources and First Results." The History of Childhood Quarterly 1 (1973): 98 - 116.

---. Public Life in Renaissance Florence. New York: Academic Press, 1980.

---. Religion and Social Context in Europe and America, 1200-1700. Tempe, AZ: Arizona Center for Medieval and Renaissance Studies, 2002.

Verdon, Timothy. Mary in Western Art. Milan: Mandadori Electa, S.p.A., 2004.

Warner, Marina. Alone of All Her Sex: The Myth and the Cult of the Virgin Mary. New York: Alfred A. Knopf, 1976.

Watson, Paul J., and Randy Thornhill, "Fluctuating Asymmetry and Sexual Selection.” Trends in Ecology and Evolution 9, no. 1 (January, 1994): 21-25.

Waynforth, David. "Fluctuating Asymmetry and Human Male Life-History Traits in Rural Belize." Proceedings: Biological Science 265, no. 1405 (August 22, 1998): 1497-1501. 
Weil, Simone. Waiting for God. Translated by Emma Craufurd. New York: G. P. Putnam's Sons, 1951.

White, Lynn. "Natural Sciences and Naturalistic Art in the Middle Ages." The American Historical Review 52, no. 3 (April 1947): 421-35.

Williamson, Beth. “Altarpieces, Liturgy, and Devotion.” Speculum 79 (2004): 341406.

---. The Madonna of Humility, Development, Dissemination and Reception. Woodbridge, UK: Boydell, 2009.

---. "The Virgin Lactans and the Madonna of Humility in Italy, Metz and Avignon in the Thirteenth and Fourteenth Centuries.” Ph.D. diss. London University, 1996.

Wind, Edgar. "Charity: The Case History of Pattern." Journal of the Warburg Institute 1, no.4 (April, 1938): 322-330.

Winston-Allen, Anne. Stories of the Rose: The Making of the Rosary in the Middle Ages. University Park, PA: Pennsylvania State University Press, 1997.

Wisch, Barbara, and Diane Cole Ahl, eds. Confraternities and the Visual Arts in Renaissance Italy: Ritual, Spectacle, Image. Cambridge, UK: Cambridge University Press, 2000.

Wood, Jeryldene M. Women, Art, and Spirituality, The Poor Clares of Early Modern Italy. Cambridge: Cambridge University Press, 1996.

Wright, Rosemary Muir. Sacred Distance: Representing the Virgin. Manchester, New York: Manchester University Press, 2006.

Yalom, Marilyn. A History of the Breast. New York: Alfred A. Knopf, 1997.

Zirpolo, Lilian H. "Artemisia Gentileschi's Spada Madonna and the Trauma of Loss.” In Essays on Women Artists, “The Most Excellent.” Book One. Edited by Liana de Girolami Cheney. Lampeter, Ceredigion, Wales: The Edwin Mellen Press, Ltd., 2003. 


\section{Cecelia M. Dorger, Ph.D. \\ 140 Lester Lane \\ Fort Thomas, KY 41075 \\ (859) 781-4334 \\ cdorger@fuse.net}

Education:

2005 - 2012 Ph.D., Art History, University of Louisville.

Concentration: Medieval and Renaissance Art and Architecture.

Dissertation: "Studies in the Madonna Lactans in Late Medieval and

Renaissance Italy"

1982 M.A., Art History, University of Cincinnati.

Concentration: Nineteenth Century Art and Architecture.

Thesis: "The Late Portrait Busts by Auguste Rodin"

1979

B.S., Art Education, University of Dayton, 1979.

\section{Experience:}

1988 - 2006 and 2012, Adjunct Instructor.

College of Mount St. Joseph, Cincinnati, Ohio.

Courses: History of World Art, History of Modern Art, History of American Art, History of Furniture and Architecture, Art Criticism, and Art Appreciation.

Interdisciplinary course: Jesus Through the Ages and Rome: A Sacred and Secular History.

Assistant Gallery Director 2003 - 2004.

1983 - 1987, Executive Director, Enjoy the Arts.

1982, Adjunct Instructor.

Northern Kentucky University.

Course: Art History Survey.

1982, Adjunct Instructor.

University of Dayton.

Course: Art History Survey.

Papers, Publications, and Presentations:

"Symbols and Icons in Christian Art," presented at the College of Mount St. Joseph.

"Sustenance for Life - The Madonna del Latte as a Backdrop for the Celebration of the

Eucharist in Late Medieval Italy," presented at The Newberry Library Center for Renaissance

Studies 2010 Multidisciplinary Graduate Student Conference.

Published in the Selected Proceedings of the Newberry Library Center for Renaissance

Studies 2010 Multidisciplinary Graduate Student Conference.

"Art of the Cathedral Basilica of the Assumption, Covington, Kentucky - Frank Duveneck

and Clement Barnhorn," Cathedral Basilica of the Assumption, Covington, KY.

\section{Scholarship Awards:}

Donald Payton Graduate Award in Art History, 2005, 2006, 2007 and 2009.

Frederick and Elizabeth Cressman Scholarship, 2008 and 2010.

The Hite School of Fine Arts Travel Award, 2011.

The Hite Scholarship, 2012.

Professional Awards: 
Excellence in Teaching Award - Adjunct Faculty, College of Mount St. Joseph, 1992 - 1993 and $2004-2005$.

Ohio Magazine's Excellence in Ohio Education Award, 2005.

Outstanding Adjunct Art Faculty, College of Mount St. Joseph - 1991. 